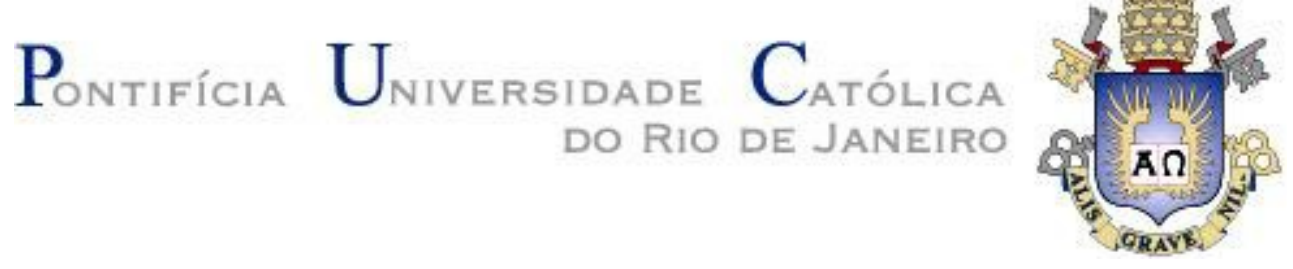

Ednéa Martins Ornella

\title{
Zc 5,5-11: contexto sócio-religioso e significado teológico
}

\section{TESE DE DOUTORADO}

\author{
DEPARTAMENTO DE TEOLOGIA \\ Programa de Pós-Graduação em Teologia
}




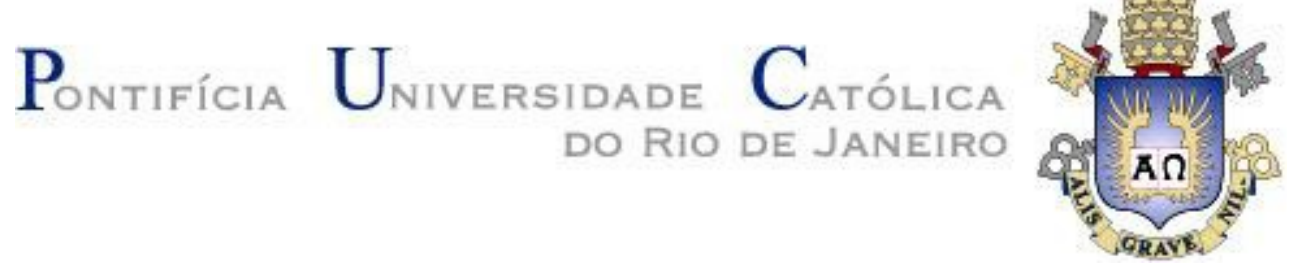

Ednéa Martins Ornella

\section{Zc 5,5-11: contexto sócio-religioso \\ e significado teológico}

Tese de Doutorado

Tese apresentada ao programa de Pós-graduação em Teologia da PUC-Rio como requisito parcial para obtenção do título de Doutor em Teologia.

Orientador: Prof. Leonardo Agostini Fernandes

Rio de Janeiro

Julho de 2019 


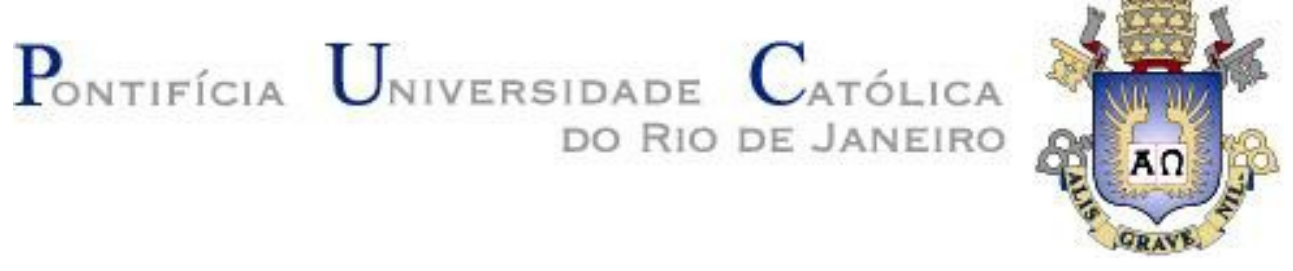

Ednéa Martins Ornella

Zc 5,5-11: contexto sócio-religioso e significado teológico

Tese de doutorado apresentada como requisito parcial para a obtenção do grau de Doutor pelo Programa de Pós-Graduação em Teologia do Departamento de Teologia do Centro de Teologia e Ciências Humanas da PUC-Rio. Aprovada pela Comissão Examinadora.

\author{
Prof. Leonardo Agostini Fernandes \\ Orientador \\ Departamento de Teologia - PUC-Rio
}

Prof. Heitor Carlos Santos Utrini Departamento de Teologia - PUC-Rio

Profa. Waldecir Gonzaga

Departamento de Teologia - PUC-Rio

Profa . Elisangela Chaves Dias Pontifícia Universidade Urbaniana - SIM

Profa. Alessandra Serra Viegas

Sem. Metodista César Dacorso Filho

Prof $^{a}$. Monah Winograd

Coordenadora Setorial do Centro de

Teologia e Ciências Humanas PUC-Rio

Rio de Janeiro, 3 de julho de 2019 
Todos os direitos reservados. É proibida a reprodução total ou parcial do trabalho sem autorização da universidade, do autor e do orientado.

\section{Ednéa Martins Ornella}

Bacharelou-se em Matemática na Universidade de Brasília em 1980. Cursou o $11^{\circ}$ Curso Básico de Exportação da Fundação de Estudos do Comércio Exterior em 1984. Participou do Curso de Matemática Financeira do Banco Central em 1985. Frequentou o $3^{\circ}$ Curso de Matemática Financeira Aplicada às Operações de Câmbio da Associação de Bancos do RJ em 1985. Participou do Curso de Matemática Financeira Aplicada ao Mercado de Capitais da Bolsa de Valores-RJ em 2000. Certificou-se nos Cursos de PósGraduação "Latu Sensu" em Ciências Contábeis em 1997 e MBA em Gestão Empresarial da Fundação Getúlio Vargas em 2003. Graduou-se em Teologia na PUC-Rio em 2010. Obteve o grau de Mestre em Teologia, também pela PUC-Rio, em 2013.

Ficha Catalográfica

Ornella, Ednéa Martins

Zc 5,5-11 : contexto sócio-religioso e significado teológico / Ednéa Martins Ornella ; orientador: Leonardo Agostini Fernandes. - 2019.

$214 \mathrm{f.} ; 30 \mathrm{~cm}$

Tese (doutorado)-Pontifícia Universidade Católica do Rio de Janeiro, Departamento de Teologia, 2019. Inclui bibliografia

1. Teologia - Teses. 2. Mulher. 3. Amor divino. 4. Pedagogia divina. 5. Iniquidade. 6. Pós-exílio. I. Fernandes, Leonardo Agostini. II. Pontifícia Universidade Católica do Rio de Janeiro. III. Título. 
Em memória de minha mãe que se alegra comigo na casa do Pai. 


\section{Agradecimentos}

Ao meu orientador Professor Leonardo Agostini Fernandes.

Ao diretor do Departamento de Teologia, professor Waldecir Gonzaga.

À PUC-Rio e ao Departamento de Teologia, pelo auxílio concedido.

Aos funcionários do Departamento de Teologia pela atenção no atendimento.

À minha família, marido, filhos, noras, neto. 


\section{Resumo}

Ornella, Ednéa Martins; Fernandes, Leonardo Agostini (Orientador). Zc 5,5-11: contexto sócio-religioso e significado teológico. Rio de Janeiro, 2019. 214 p. Tese de Doutorado - Departamento de Teologia, Pontifícia Universidade Católica do Rio de Janeiro.

Este trabalho estuda a sétima visão do profeta Zacarias (Zc 5,5-11). A pesquisa surgiu da análise das interpretações que apresentam as seguintes questões: 1. tendência misógina, que atribui à "mulher" o mal, em detrimento do significado do todo que foi revelado: o "efá"; o "olho deles em toda a terra"; os elementos utilizados para tampar o efá e aprisionar a mulher ("disco", "pedra" e "chumbo"); 2. a remoção do mal, sem morte e destruição: "duas mulheres" com "asas como de cegonha", com "vento em suas asas", levantam o efá "entre a terra e os céus" e o levam para "Senaar", onde uma "casa" será "construída", "preparada", e onde será "assentado" sobre sua "base". Chama a atenção uma mulher sentada e aprisionada dentro de um efá. O objetivo do estudo é compreender o sentido da extraordinária imagem visionada e dos elementos revelados, no seu contexto sócio-religioso, e o significado teológico da visão. Para isso, foram feitos pesquisa bibliográfica dos últimos 50 anos, análise textual com utilização do método histórico-crítico e análise sincrônica, considerando o texto canônico. Diferentemente das interpretações existentes, que consideram a mulher pecadora e sedutora, concluiu-se que determinado grupo que retornava do exílio na Babilônia, com ideais proféticos, fiel à religião e às tradições, pretendia a mulher sentada no meio do efá (submetida) e prisioneira, por se mostrar com protagonismo com o qual o grupo não concordava. A remoção do mal com final feliz é a resposta de YHWH a este grupo, uma teologia, na qual prevalece a Pedagogia e o Amor divinos para com a mulher e os transgressores, a quem YHWH concede espaço e cuidado para que voltem e se reintegrem à sociedade.

\section{Palavras-chave}

Mulher; Amor divino; Pedagogia divina; Iniquidade; Pós-exílio. 


\section{Abstract}

Ornella, Ednéa Martins; Fernandes, Leonardo Agostini (Advisor). Zech 5:511: socio-religious context and theological significance. Rio de Janeiro, 2019. 214 p. Doctorate Thesis - Department of Theology, Pontifical Catholic University of Rio de Janeiro.

This essay aims to study the seventh vision of the prophet Zechariah (Zech 5:5-11). The research arose from the analysis of interpretations presenting the following issues: 1. a misogynist tendency, which associates "women" with wickedness to the detriment of the significance of all that was revealed: the "ephah", "their eye through all the earth"; the elements used to cover the ephah and entrap the woman inside it ("disk", "stone", and "lead"); 2. the removal of wickedness without death and destruction: "two women" with "wings like the wings of a stork", with "wind in their wings", lift the ephah up "between the earth and the heaven" and take it to "Shinar", where a "house" will be "built" and "prepared" for it, and it will "be set" there upon her own "base". The image of an entrapped woman sitting inside an ephah is noteworthy. The objective of this study is to understand the meaning of the extraordinary image envisioned and the elements revealed in it in their socio-religious context, as well as the theological meaning of the vision. For this, a bibliographical research of the last 50 years was carried out alongside with textual analysis using the historical-critical method and synchronic analysis considering the canonical text. Unlike the existing interpretations that consider women as sinful and seductive, this paper concludes that a certain group of exiles returning from Babylon, faithful to religion and tradition and with prophetic ideals, intended for the woman to be sitting in the ephah, (submitted) as a prisoner, for presenting herself with a leading role with which they did not agree. The removal of wickedness with a happy ending is YHWH's response to this group, a theology in which divine Pedagogy and Love prevails towards women and offenders, to whom YHWH grants space and care to allow them to return and be reintegrated into society.

\section{Keywords}

Woman; Divine Love; Divine Pedagogy; Wickedness; Post-exile. 


\section{Sumário}

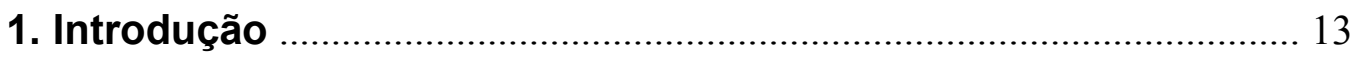

2. História da interpretação do texto (Status Quaestionis) ................ 16

2.1.Hipóteses relativas a Zc 5,5-8 .......................................................... 19

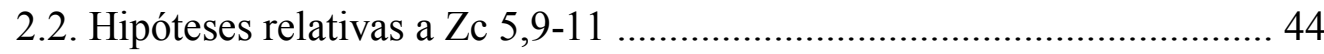

2.3. Nova proposta de interpretação para Zc 5,5-11 .................................... 69

3. $O$ livro do profeta Zacarias …………………………........................... 72

3.1. Origem e redação ............................................................................... 72

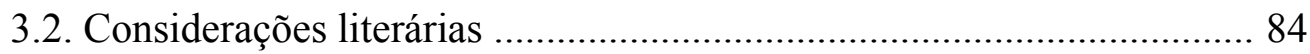

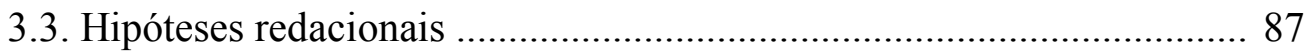

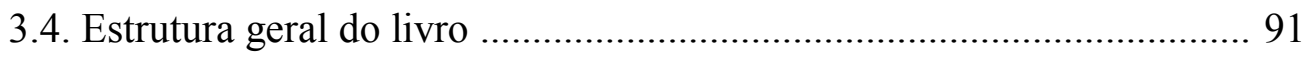

4. Contexto social e religioso do retorno do exílio .............................. 95

4.1. Acontecimentos anteriores ao retorno ................................................ 95

4.2. Formação de grupos de liderança ...................................................... 100

4.3. Constituição sócio-cultural do povo ................................................... 104

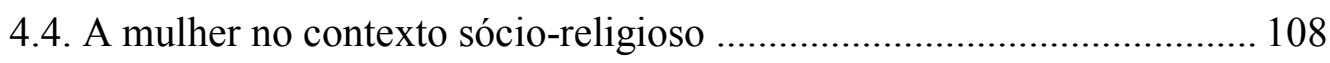

5. O texto, sua constituição e organização ......................................... 132

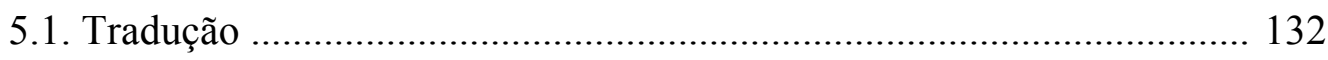

5.2. Notas de crítica textual .................................................................... 133

5.3. Delimitação e unidade ..................................................................... 137

5.4. Organização do texto ..................................................................... 140

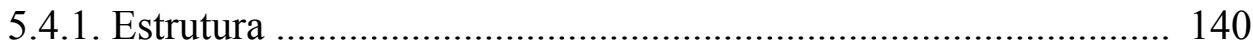

5.4.2. Ato cênico .................................................................................... 141

5.5. Gênero literário …........................................................................ 143

6. Significado teológico de Zc 5,5-11 ................................................... 145

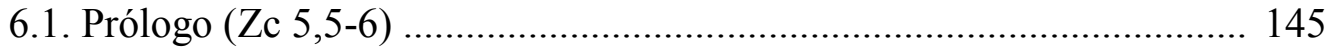

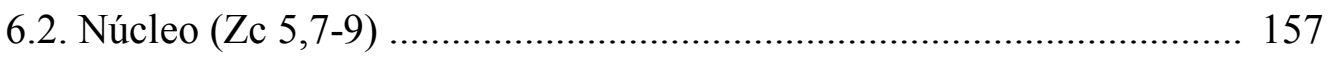

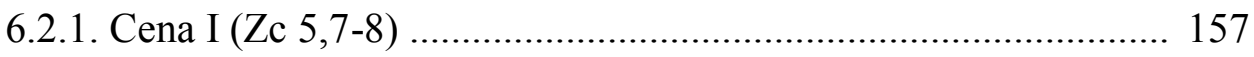

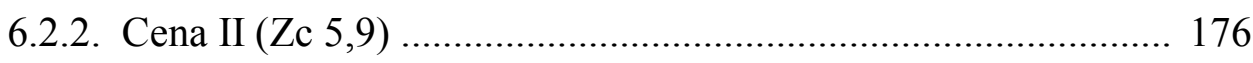

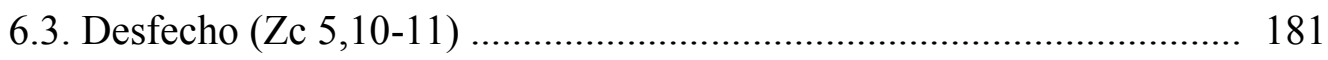

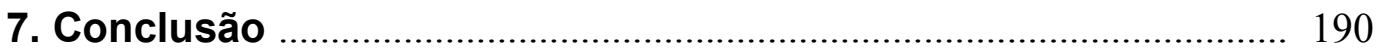

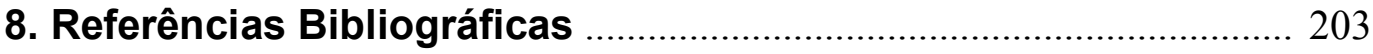




\section{Abreviaturas}

\section{Comentários, Dicionários e Léxicos}

DBHP Dicionário Bíblico Hebraico-Português

DPB Diccionario del profetismo Bíblico

DTFANT Dicionário de termos teológicos fundamentais do Antigo e do Novo Testamento

CBNV Comentário Bíblico Nova Vida

CBPAT Comentário bíblico popular Antigo Testamento

TDOT Theological Dictionary of the Old Testament

BDB The Brown-Driver-Briggs Hebrew and English Lexicon

BKAT Biblischer Kommentar, Altes Testament. Edited by M. Noth and $\mathrm{H}$.

W. Wolff

DITAT Dicionário Internacional de Teologia do Antigo Testamento

LHAAT Léxico Hebraico e Aramaico do Antigo Testamento

DCT Dicionário Crítico de Teologia

LGPNT Léxico Grego-Português do Novo Testamento

DB Dicionário Bíblico

DBHP Dicionário bíblico hebraico-português

NDITEAT Novo Dicionário Internacional de Teologia e Exegese do Antigo Testamento

\section{Periódicos}

AJSL Ancient Israel and Its Literature

ATeo Revista Atualidade Teológica

Bib Biblica

BK Bibel Und Kirche

BWAT Beiträge zur Wissenschaft vom Alten und Neuen Testament

CBQ Catholic Biblical Quarterly

JBL Journal of Biblical Literature

JHS Journal of Hebrew Scripture

JJS Journal of Jewish Studies 


$\begin{array}{ll}\text { JSOT } & \text { Journal for the Study of the Old Testament } \\ \text { REET } & \text { Revista Eletrônica Espaço Teológico } \\ \text { RHR } & \text { Revue de l'histoire des religions } \\ \text { SBL } & \text { Society of Biblical Literature } \\ \text { SJOT } & \text { Scandinavian Journal of the Old Testament } \\ \text { VT } & \text { Vetus Testamentum } \\ \text { ZThK } & \text { Zeitschrift für Theologie und Kirche }\end{array}$

\section{Gramáticas}

GHG Gesenius' Hebrew Grammar. Edited by E. Kautzsch. Translated by A. E. Cowley. 2d. ed. Oxford, 1910.

GBH A Grammar of Biblical Hebrew. Joüon P.; Muraoka T., 2ed. Gregorian \& Biblical Press, Roma, 2013.

\begin{tabular}{|c|c|}
\hline \multicolumn{2}{|c|}{ Livros Bíblicos } \\
\hline $1 \mathrm{Cr}$ & Primeiro Livro das Crônicas \\
\hline $2 \mathrm{Cr}$ & Segundo Livro das Crônicas \\
\hline $1 \mathrm{Rs}$ & Primeiro Livro dos Reis \\
\hline $2 \mathrm{Rs}$ & Segundo Livro dos Reis \\
\hline $1 \mathrm{Sm}$ & Primeiro Livro de Samuel \\
\hline $2 \mathrm{Sm}$ & Segundo Livro de Samuel \\
\hline $\mathrm{Ag}$ & Ageu \\
\hline Am & Amós \\
\hline $\mathrm{Ct}$ & Cântico dos Cânticos \\
\hline Dt & Deuteronômio \\
\hline Ecle & Eclesiastes \\
\hline Eclo & Eclesiástico \\
\hline Esd & Esdras \\
\hline Ex & Exodo \\
\hline Ez & Ezequiel \\
\hline Gn & Gênesis \\
\hline Is & Isaías \\
\hline Jó & Jó \\
\hline
\end{tabular}




$\begin{array}{ll}\mathrm{Jr} & \text { Jeremias } \\ \mathrm{Js} & \text { Josué } \\ \mathrm{Jz} & \text { Juízes } \\ \mathrm{Lv} & \text { Levítico } \\ \mathrm{Mq} & \text { Miqueias } \\ \mathrm{Mt} & \text { Mateus } \\ \mathrm{Ne} & \text { Neemias } \\ \mathrm{Nm} & \text { Números } \\ \mathrm{Pr} & \text { Provérbios } \\ \mathrm{Rt} & \text { Rute } \\ \mathrm{Sl} & \text { Salmos } \\ \mathrm{Zc} & \text { Zacarias }\end{array}$

Gerais

\begin{tabular}{|c|c|}
\hline $\mathrm{AOP}$ & Antigo Oriente Próximo \\
\hline $\mathrm{AOM}$ & Antigo Oriente Médio \\
\hline AT & Antigo Testamento \\
\hline BHQ & Biblia Hebraica Quinta \\
\hline Cf. & Conferir \\
\hline Ed.(s) & Editor(es) \\
\hline$M^{L}$ & Texto Massorético Leningradense \\
\hline NAB & The New American Bible \\
\hline NT & Novo Testamento \\
\hline Org.(s) & Organizador(es) \\
\hline LXX & Septuaginta \\
\hline TEB & Tradução Ecumênica da Bíblia \\
\hline
\end{tabular}




\section{Introdução}

O livro do profeta Zacarias (Zc 1-14) é o penúltimo livro do corpus dos Doze, entre os livros dos profetas Ageu e Malaquias, cuja primeira parte, o Proto Zacarias (Zc 1-8), constitui uma unidade independente, onde se encontra o ciclo das oito visões do profeta (Zc 1,17-6,15), uma subunidade da qual faz parte Zc 5,5-11, a sétima visão. Esta visão apresenta extraordinárias imagens simbólicas (o "olho deles em toda a terra"; o "efá"; "uma mulher sentada no meio do efá"; uma tampa, que aprisiona a mulher, constituída de "disco"/"pedra" e "chumbo") e um desfecho surpreendente, com a remoção do mal sem morte ou destruição ("duas mulheres com asas de cegonha", com "vento" em suas asas, levantam o efá "entre a terra e os céus"; e o levam para a "terra de Senaar", onde uma "casa" será "construída”, "preparada, e onde será "assentado sobre sua base”).

A intrigante interpretação de Elie Assis $(2010)^{1}$ para a visão atribui à “mulher" no efá a representação dos samaritanos, tidos como adversários dos judeus. $\mathrm{O}$ autor parte do episódio da recusa dos judeus em aceitar a ajuda dos samaritanos nas obras de reconstrução do Templo (cf. Esd 4,1-3), os quais, em represália, denunciaram os judeus ao Império Persa, atrasando os trabalhos (cf.

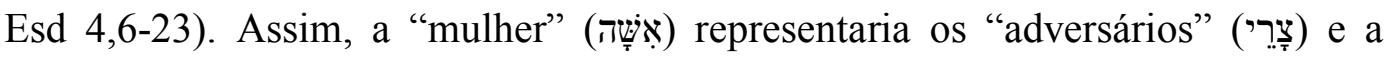

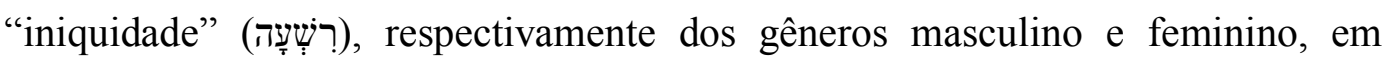
hebraico, sendo utilizado o vocábulo "iniquidade" porque os samaritanos são simbolizados por "uma mulher".

Observou-se nesta intepretação uma tendência misógina que não existe no texto bíblico e faz levantar várias questões: Quem era essa “uma mulher", sentada (submetida) no meio do efá e fechada com uma tampa de chumbo? Qual foi sua transgressão? Por que não foi punida com morte ou destruição? O que significavam os outros elementos? Qual o contexto sócio-religioso onde se inserem a mulher, em especial, e os demais elementos? Quais os elementos teológicos de Zc 5,5-11?

Elie Assis acredita que sua interpretação resolve o problema da remoção para a Babilônia (Senaar) porque é a terra de origem dos samaritanos, mas o autor

\footnotetext{
${ }^{1}$ Cf. E. ASSIS, “Zechariah's Vision of the Ephah (Zech. 5:5-11)”. In: VT 60 (2010), p. 15-32.
} 
não consegue justificar adequadamente a remoção em que o inimigo é tratado com cuidado amoroso. A remoção, com misericórdia e salvação explícita para o iníquo, causa impacto ao leitor e deixa intérpretes sem explicações para o juízo divino, acostumados às ideias de ira e justiça.

A dupla imputação de iniquidade à imagem da mulher na interpretação de Elie Assis, como "adversários" de Judá e depois como a própria "iniquidade”, traz à tona a longa tradição misógina nas interpretações bíblicas. Estas interpretações não têm raízes nos próprios textos, mas em análises que surgiram no passado, e que se prolongaram e se consolidaram ao longo do tempo, trazendo resultados negativos para a mulher. A combinação de diferentes correntes e culturas criou uma mistura de argumentos extremamente danosos à confiabilidade das mulheres, relacionando-as com o mal. Chega-se a afirmar que "Zc 5,5-8 é um ponto alto da difamação genérica das mulheres".2

A tendência interpretativa, que coloca a mulher como símbolo da iniquidade, ignorou os significados dos demais elementos da visão, que têm um papel fundamental dentro da própria experiência e lógica proféticas. ${ }^{3}$ Nesse sentido, este estudo se propõe a interpretar os elementos de Zc 5,5-11, no seu contexto sócio-religioso, para discernir o significado teológico da visão do texto.

O presente trabalho divide-se em oito unidades: uma introdução, cinco capítulos, necessários à compreensão do desenvolvimento do estudo, e uma conclusão. Antes de analisar como se chegou a atribuir um significado negativo à mulher, e com a intenção de perceber o sentido da visão, serão analisados artigos e comentários dos últimos cinquenta anos, sem a pretensão de esgotar os textos existentes. Assim, se poderá avaliar o histórico das hipóteses formuladas neste período para se traçar uma análise dos significados teológicos da visão e dos elementos revelados na experiência visionária de Zc 5,5-11.

A partir destes estudos, voltar-se-á a atenção para o desenvolvimento literário de Zc 1-8, onde se insere a visão, sua autoria, data e composição. A análise destes materiais e um esboço dos textos, em particular do ciclo de visões

\footnotetext{
${ }^{2}$ Cf. E. S. GERSTENBERGER, Israel no tempo dos persas, séculos V e IV antes de Cristo. São Paulo: Loyola, 2005, p. 503.

${ }^{3}$ Cf. R. A. WERLINE, "Assessing the Prophetic Vision and Dream Texts for Insights into Religious Experience". In: E. R. HAYES, L-S. TIEMEYER, L-S. (orgs.), I Lifted My Eyes And Saw, Reading Dream and Vision Reports in The Hebrew Bible. London; Oxford; New York; New Delhi; Sydney: Bloomsbury, 2014, p. 1-15.
} 
(Zc 1,7-6,15), proporcionarão um panorama mais apurado de Zc 5,5-11 em seu contexto literário.

O sentido de Zc 5,5-11 e o significado de seus elementos serão estudados em seu contexto sócio-religioso, tendo como pressuposto que o profeta Zacarias atuou ao lado de Ageu na época da reconstrução do Templo (cf. Esd 5,1). Para uma avaliação mais criteriosa, procurar-se-á saber, a partir dos acontecimentos que desembocaram no exílio na Babilônia, quem foi o povo do retorno e que expectativas e ideais fizeram com que se deslocasse para Jerusalém, após décadas no exílio.

A análise exegética de Zc 5,5-11 permitirá examinar a formação da unidade textual, sua integralidade e coesão. A tradução, mais próxima possível do $\mathrm{M}^{\mathrm{L}}$ e as relações semânticas e temáticas apresentadas permitirão determinar a estrutura sobre a qual se vai trabalhar e orientar o sentido teológico da visão.

Com base na estrutura apurada, à luz do contexto sócio-religioso, se examinará cada versículo, para apuração do sentido dos elementos da visão que implicarão a compreensão e interpretação do texto. Ao final desta análise se poderá chegar à mensagem teológica inscrita na experiência visionária do profeta em Zc 5,5-11.

A realidade histórica surgirá das reflexões teológicas atreladas aos símbolos dos elementos no contexto da reorganização da sociedade judaica. A fala profética reflete a busca por uma vida com fé em YHWH, com um culto correto e justiça social. A conclusão permitirá discernir sobre a mensagem divina e suas implicações para a Igreja hoje, com ênfase no papel feminino, cuja interpretação bíblica foi condicionada historicamente por uma tendência misógina, em detrimento da mulher, identificada com o mal e a concupiscência. A Igreja tem papel importante no enfrentamento das injustiças sociais, do qual não pode se furtar.

Este estudo se apresenta, também, como uma oportunidade de promover o processo dialético como forma de alavancar a valorização dos papéis sociais. A prática da leitura de textos bíblicos, a partir de um olhar feminino, contribui para desfazer a imagem devastadora para a mulher que perdura há séculos. 


\section{2}

\section{História da interpretação do texto (Status Quaestionis)}

Zc 5,5-11 é uma das mais complexas visões do ciclo de visões do profeta Zacarias (cf. Zc 1,7-6,15) em função de: a) apresentação sob forma de perguntas e respostas; b) riqueza de imagens; c) cenas extraordinárias, apresentadas abruptamente uma atrás da outra; d) pronomes utilizados de modo discrepante; e) desfecho extraordinário. Além disso, esta visão não possui um oráculo para auxiliar na interpretação da mensagem.

Desta forma, Zc 5,5-11 levanta várias questões. O que representam o efá, o olho deles em toda a terra e uma mulher sentada no meio do efá? Por que foram escolhidas duas mulheres com asas, como asas de cegonha, para fazer a remoção do efá? Por que a terra de Senaar foi escolhida como destino do efá? Por que se constrói uma estrutura arquitetônica para o efá com uma casa e uma base para que ele seja assentado (vv.11b-d)? As discrepâncias de gêneros que ocorrem na visão (com o masculino em referência ao feminino e vice-versa) têm algum objetivo ou são apenas erros de edição (vv.6b.d; 9d; 10b)?

Apesar de tantas indagações, os estudiosos mostram-se unânimes em concordar que o sentido geral da visão é a remoção do mal da comunidade do início do pós-exílio, como forma de reestruturação de uma sociedade que se empenhava em se reorganizar no novo cenário de dominação persa, trabalhando na reconstrução do Templo para que YHWH também voltasse a Jerusalém.

Embora estes estudiosos concordem quanto ao sentido final da visão, em relação aos elementos, diferem bastante em suas análises. A LXX orientou os exegetas quanto ao caminho a ser trilhado para uma interpretação ao traduzir o

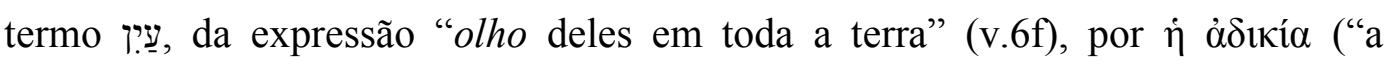
iniquidade”). Escrita a partir do século III a.C., muitos a seguiram, provavelmente devido à sua importância dentro da exegese bíblica como a primeira versão da Bíblia hebraica em grego.

Na leitura que a LXX fez de "olho" (עַיְ), é possível que o tradutor tenha considerado que, pela semelhança de formas em hebraico, a consoante waw fora

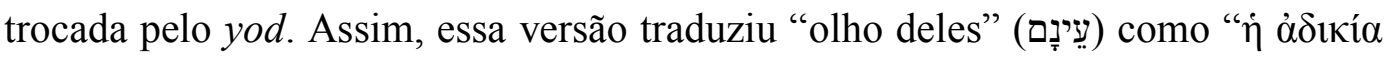

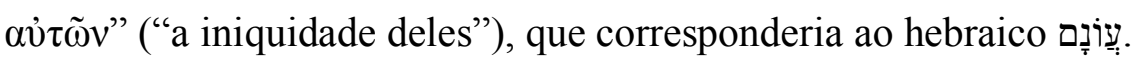


No entanto, mais tarde, uma versão do Targum de Zc 5,5-11 enfatizou o papel do "efá" (איפָּה), utilizando versículos significativamente mais longos que a versão grega. O Targum interpretou a mensagem central de Zc 5,5-1, o efá, como "a medida falsa que tornou iníquo o povo de Israel", lembrando o exílio como punição para Israel. ${ }^{4}$

$\mathrm{O}$ efá foi visto como uma medida injusta que provocou a iniquidade do povo, levando-o ao exílio, e os demais elementos foram colocados no contexto de injustiça social. Substituiu-se o "efá" por "as pessoas que tiraram e deram com a medida falsa"; o "olho deles em toda a terra" por "aqueles que estão indo para o exílio antes de todos os habitantes da terra"; a "mulher" por "outros povos vieram e habitaram em seu lugar"; a "iniquidade" por "culpados"; e as "duas mulheres com asas como de cegonha" por "duas províncias ou inspetorias". 5

O Targum enfatiza as questões ligadas às condições econômicas e à justiça social no início do retorno do exílio na Babilônia. Assim, foi ressaltado o papel negativo do efá, mas a figura da mulher, que poderia gerar estranheza, nem sequer foi mencionada. A imagem da mulher foi ignorada completamente. ${ }^{6}$

Contudo, esta versão parece ter deixado o texto mais próximo do hebraico, onde o efá é citado cinco vezes (vv.6d; 7b; 8c; 9f; 10b). O Targum expressa o sentido do texto para os judeus dos séculos V-IV a.C. Na verdade, a LXX e o Targum, juntos, contribuíram para o entendimento de Zc 5,5-11, a primeira lendo elemento por elemento, com pequenas inconsistências, e a segunda adicionando significado mais profundo dentro de seu contexto social e religioso.

Rashi (Rabbi Solomon ben Isaac), no século XII, apresentou outra interpretação, tão ou mais focada no efá que a tradução aramaica do Targum. Rashi afirma que na expressão o "olho deles em toda a terra" (v.6f) o conjunto "olho deles" seria referente aos olhos dos ímpios que roubavam e enganavam com o efá (cf. Am 8,5), e que seriam punidos com justa retribuição. A ênfase que Rashi imprime ao efá inclui a mulher dentro do conceito de medida falsificada. Ela se torna "medida adulterada", sendo assumida como a "iniquidade" que deve ser removida como um símbolo genérico no qual se situam todos os problemas. O

\footnotetext{
${ }^{4}$ Cf. H. BUNCE, “Translation and Interpretation: Targum and Septuagint in Zechariah 5:5-11”. In: CBW 5/31 (2011), p. 53-65.

${ }^{5}$ Cf. H. BUNCE, "Translation and Interpretation: Targum and Septuagint in Zechariah 5:5-11", p. 53-65.

${ }^{6}$ Cf. M. DELCOR, "La vision de la femme dans l'épha de Zach., 5,5-11 à la lumière de la littérature hittite". In: RHR 187/2 (1975), p. 137-145.
} 
efá, então, assume dupla função correspondente ao conceito de Talião: o efá com que se falsifica, com ele o iníquo será punido. ${ }^{7}$

Marenof (1932), ${ }^{8}$ cerca de oito séculos mais tarde, deu início a uma interpretação de Zc 5,5-11 com base no "efá (v.6d) e no "olho deles em toda a terra" (v.6f). Sua interpretação servirá de fundamento a muitos outros estudiosos, por muitas décadas, e ajudará a encontrar resposta para o sentido dos demais elementos dentro de um quadro de idolatria ou culpa.

Marenof fez seu estudo a partir do termo "efá", associado ao substantivo sufixado “olho deles" (עינָם) no v.6f, relacionando o efá aos zigurates existentes na Babilônia. Estas torres possuíam de três a sete andares e eram consideradas construções sagradas em honra de divindades. Marenof acreditou que o efá em Zc 5,5-11 fosse uma alusão à pequena sala de um zigurate e, portanto, um santuário. Para fundamentar sua ideia, procurou, através de estudo cuidadoso, mostrar que o efá, na visão de Zc 5,5-11, não tinha qualquer relação com a vasilha de medição, podendo ter a mesma raiz que as palavras assírias $A$-pu ("gruta") e $A$-ptu ("sala") e árabe Afta ("sala"), que deram origem mais tarde ao verbo Apu (“construir"). 9

Marenof verificou que existira um zigurate em Lagash de nome E-pa, nome de origem suméria, cujo significado é "a casa do topo", palavra tomada de empréstimo da língua assíria. ${ }^{10}$ A partir daí, então, estabeleceu uma relação semântica entre as palavras E-pa e אִיפָ, e concluiu ser possível que Zacarias tenha usado o substantivo אִיפָ como um termo para indicar um dos edifícios das divindades do AOP, no período após a destruição do primeiro Templo de Jerusalém. Considerou também que, se o efá representava um zigurate, então era possível que o profeta tivesse usado a expressão "olho deles" (v.6f) para referir-se

\footnotetext{
${ }^{7}$ Cf. J. SCHNOCKS, "An Ephah Between Earth and Heaven". In: M. J. BODA; M. FLOYD (orgs.), Tradition in Transition Haggai and Zechariah 1-8 in the Trajectory of Hebrew Theology. New York / London: T\&T Clark, 2008, p. 252-270.

${ }^{8}$ Cf. S. MARENOF, 'Note Concerning the Meaning of the Word 'Ephah', Zechariah 5:5-11". In: AJSL 48/4 (1932), p. 264-267.

${ }^{9}$ Cf. S. MARENOF, "Note Concerning the Meaning of the Word 'Ephah', Zechariah 5:5-11", p. 264-267.

${ }^{10} \mathrm{O}$ termo e-pa pode ter entrado no hebraico como uma loanword (palavra estrangeira incorporada a um idioma), semelhante ao e-gal (hêkäl) (cf. D. L. PETERSEN, Haggai and Zechariah 1-8: A Commentary. Philadelphia / Pennsylvania: The Westminster Press, 1984, p. 254-263).
} 
ao efá como "sua aparência". A "casa" (v.11b) a ser construída seria um "templo" para assentar o "efá", um "santuário". 11

A partir dessas considerações, a história da interpretação de Zc 5,5-11 será tratada em dois momentos. Primeiro, em Zc 5,5-8, seção em que os estudiosos se detiveram com maior atenção, depois, em Zc 5,9-11, que, de maneira geral, despertou menos interesse dos interprétes, e onde se encontra o desfecho da visão com remoção, sem morte e destruição.

\section{1.}

\section{Hipóteses relativas a Zc 5,5-8}

\section{a) Estudos que seguem Marenof}

Alguns estudiosos seguiram o caminho da interpretação aberto por Marenof, associando o efá, às vezes explicitamente, outras implicitamente, ao termo sumeriano E-pa, que se refere a uma sala de culto a um deus no alto de um templo mesopotâmico. Contudo, nem todos os autores assumiram o "olho deles" como a "aparência do efá".

C. L. Meyers e E. M. Meyers (1987), ${ }^{12}$ cerca de cinquenta anos depois de Marenof, analisaram a estrutura da visão, acreditando que ela começaria no v.9, com o anúncio sobre o destino do efá, em três movimentos, tendo como prelúdio uma introdução mais extensa. Esta divisão leva em conta o dinamismo da visão dado pelos verbos de movimento: "sair", "lançar" (v.8), "levantar" (v.9 e v.10), “construir" e "assentar" (v.11). O movimento criado identifica, então, um a um, os elementos e o desdobrar de suas ações para dar sentido à visão como um todo.

A mulher no efá tanto pode ser um símbolo da idolatria e iniquidade como ser mulheres estrangeiras que introduziram cultos pagãos na comunidade javista. Há na visão características de um “continuum cultural que durou no Crescente Fértil, pelo menos no seu centro, da Palestina ao seu término no oriente na

\footnotetext{
${ }^{11}$ Para S. MARENOF ("Note Concerning the Meaning of the Word 'Ephah', Zechariah 5:5-11", p.

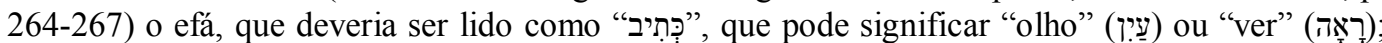
seria uma representação dos zigurates, chamados também "casa do conspícuo". Assumindo-se que o efá representa um zigurate, a leitura de "olho deles" (עינָּ) estaria correta.

${ }^{12}$ Cf. C. L. MEYERS; E. M. MEYERS, Haggai, Zechariah 1-8. New Haven / London: The Anchor Yale Bible, 1987, p. 309-316.
} 
Mesopotâmia". A mulher no efá representa a idolatria e a esposa estrangeira responsável pelo culto pagão. A compreensão do efá como um santuário encontra fundamento em sua utilização nos templos babilônicos. Se o efá pode ser associado a um santuário na Mesopotâmia, o "olho deles" pode estar se referindo corretamente à sua visibilidade.

O disco ou pedra de chumbo, com qualidades mágicas, é conhecido do povo de Israel por causa de certas práticas assírio-babilônicas associadas à fundação e reconstrução de templos. O culto pagão fascina as pessoas. A idolatria é uma questão residual resultante da longa história de contaminação cúltica de Israel. A temática do ciclo de visões $(Z c$ 1,7-6,15) seria o "status de YHWH no mundo", que deveria ser compreendido a partir do contexto do domínio do império persa, no século VI a.C. Nesta estrutura e dentro desta temática, Zc 2,1-4 e Zc 5,5-11 formam um par e seus elementos se relacionam: os chifres e a mulher no efá (entendida como deusa) representando nações estrangeiras; os ferreiros e as duas mulheres com asas de cegonha representando agentes de YHWH na história. $^{13}$

T. McComiskey $(1992)^{14}$ também interpretou o "olho deles" como a "aparência deles", analisando a partir do pronome זٓ (v.6f), em referência ao que ainda não tinha sido visto, mas introduzido e apresentado como a "iniquidade" (v.8b). A expressão o "olho deles" (v.6f) significaria "esta é a aparência deles", em referência aos violadores da aliança, representados pela mulher sentada no meio do efá (v.7b).

Para a antecipação da apresentação da iniquidade haveria duas hipóteses de leitura: a) a LXX e a Siríaca estariam corretas quando leem עִינָם como a "iniquidade deles"; ou b) se criaria um embaraço com a força direcional de זאת (v.7b) fazendo referência à mulher no efá, o que identificaria a mulher duas vezes como personificação do mal dentro da comunidade. No entanto, se a dupla identificação da mulher como iniquidade estivesse correta, não haveria sentido na expressão "e ele disse" (vv.6e; 8a), bastaria o emprego de "זr" (v.8b). Assim, para evitar dificuldades na leitura, deve-se ler o "olho deles" como a "aparência deles", que faz mais sentido dentro da visão.

\footnotetext{
${ }^{13}$ C. L. MEYERS; E. M. MEYERS, Haggai, Zechariah 1-8, p. 309-316.

${ }^{14}$ Cf. T. E. McCOMISKEY, "Zechariah". In: T. McCOMISKEY (ed.), An Exegetical \& Expository Commentary, The Minor Prophets, v. 3. Michigan: BakerAcademic / Grand Rapids, 1992, p. 1099-1104.
} 
A tampa, que parece levantar-se sozinha de forma misteriosa (v.7a), mostra uma mulher sentada no meio do efá, que seria a manifestação simbólica da iniquidade deles. Deve-se a escolha da "mulher" (Ẉ) para representar a “iniquidade" (רְֹשְעָעה) ao gênero feminino em hebraico desta última. Por trás de Zc 5,5-11 está o cumprimento da promessa divina da nova aliança (cf. Jr 31,33-34) e o aviso de que a remoção da iniquidade já começara (cf. Zc 3,1-5 e Zc 5,1-4).

Para C. Uehlinger (1994), ${ }^{15}$ Zc 5,5-11 faz parte do processo de confissão de fé monoteísta em Judá do pós-exílio, quando se discutia uma práxis religiosa correta de adoração a YHWH. Esta visão estaria, portanto, tratando da deportação de uma deusa. O efá seria uma vasilha de unidade de medida, comentado pelo profeta por meio da interrogativa “o que é aquilo?" (v.6b), apontando para o seu conteúdo, a mulher (v.7b). Deve-se pensar na mulher no meio do efá como uma deusa, e na iniquidade como símbolo do pecado cultual.

O fato de a mulher estar sentada remete para representações do período persa, documentadas pela arqueologia. A representação que mais se aproxima é a da chamada Dea Tyria grávida, uma terracota votiva de uma mulher grávida, de vestido longo e penteado cheio, sentada num trono, com a mão direita sobre o ventre levemente abaulado. A longa tradição de representações embasa a interpretação da mulher como uma deusa. $\mathrm{O}$ fato de o disco de chumbo que fechava o efá precisar ser levantado (v.7a) indica que seu conteúdo era proibido. O mensageiro desqualifica a mulher chamando-a de "iniquidade" (v.8b). "Iniquidade" significaria, neste contexto, qualidade daquele que está sem YHWH.

J. Schnocks (2008) ${ }^{16}$ interpretou Zc 5,5-11 depois de avaliar as leituras do $\mathrm{M}^{\mathrm{L}}$, da LXX, do Targum e de Rashi, sob o ponto de vista da história das religiões e das tradições proféticas, no nível textual imediato da visão. Com isso, levantou critérios para compreensão da visão que considerou poder ser explicada à luz de Ez 8. O "olho" (עַיָ) teria o sentido de "aparência" (cf. Lv 13,55), com uma sutil diferença, o sentido seria de "percepção" e não aquilo que é simplesmente visto. Com este significado, o substantivo "עַיע." teria diferentes nuances, como se fosse um trocadilho.

\footnotetext{
15 Cf. C. UEHLINGER, "Die Frau im Efa (Sach 5,5-11), Eine program-vision von der Abschiebung der Göttin”. In: BK 49/2 (1994), p. 93-102.

${ }^{16}$ Cf. J. SCHNOCKS, “An Ephah between Earth and Heaven”, p. 252-270.
} 
O efá poderia, então, ser visto como aquilo que os sete olhos de YHWH detectaram enquanto vagueavam "em toda a terra", e o sufixo seria uma referência aos habitantes da terra ("isto é o que se tornou visível neles em toda a terra”). Para J. Schnocks, esta interpretação é sustentada pela quarta visão, Zc 3,1-4, com a promessa divina de remover toda a iniquidade da terra (cf. Zc 3,9), que se realiza em Zc 5,5-11. Embora de forma diferente, a ligação entre o "olho deles" e a “iniquidade", já feita pela LXX, coloca a iniquidade (v.8b) como o conteúdo central da visão. Contudo, não se deve restringir o sentido da visão ao culto a uma deusa, uma vez que não há fundamento nem na semântica nem em descobertas arqueológicas. Tendo características de substantivo abstrato, a "iniquidade"

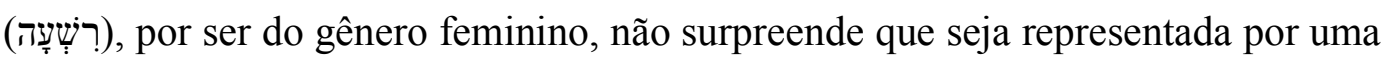
mulher (v.7b). Zc 5,5-11 é uma visão que, por sua forma e conteúdo, dá continuidade às tradições proféticas do antigo Israel. Terminologicamente, Zc 5,511 se aproxima de Ezequiel, mas teologicamente difere ao apresentar a busca e a libertação da injustiça como ação e misericórdia de YHWH com Judá e Jerusalém.

\section{Sintese}

C. L. Meyers e E. M. Meyers, C. Uehlinger e Schnocks interpretaram o efá (v.6d) como um santuário e a mulher no seu interior (v.7b) como uma deusa. Schnocks, porém, lembra que o sentido de Zc 5,5-11 não deve ficar restrito à idolatria, pois não há fundamento semântico e arqueológico para isso.

Nas interpretações deste grupo, em que "olho deles em toda a terra" (v.6f) tem o sentido de "visibilidade" ou "aparência" do efá, nem sempre essa relação estabelecida por Marenof é mantida. T. McComiskey entende a visibilidade da mulher como representação dos violadores da aliança. Para J. Schnocks é como YHWH vê os habitantes da terra, enquanto seus olhos vagueavam em toda a terra. Neste caso, o efá (vv.6d.7b.8c.9f) pode ter sido até ignorado (T. McComiskey).

Somente C. L. Meyers e E. M. Meyers analisaram e interpretaram os elementos utilizados na tampa do efá, o disco (v.7a) e a pedra (v.8d), ambos de chumbo. Para estes autores, se o efá é um santuário, disco e pedra de chumbo têm relação com as propriedades mágicas deste material, conhecido no mundo antigo de Israel por causa das práticas assírio-babilônicas associadas às fundações e construções de templos. Os demais estudiosos ignoram estes elementos. 


\section{b) Estudos que explicitamente seguem a LXX}

Estudiosos seguiram o caminho da interpretação aberto pela LXX, considerando o "olho deles em toda a terra" (v.6f) como a "iniquidade deles em toda a terra", deixando esta questão bem clara, como se pode ver a seguir.

J. G. Baldwin (1972) ${ }^{17}$ segue explicitamente a LXX no que diz respeito à

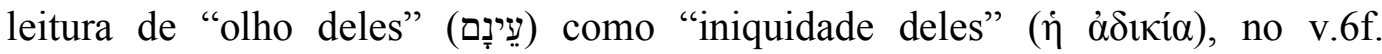
Interpreta o efá como símbolo da iniquidade, ampliando o alcance das infrações. O efá, uma unidade de medida de grãos secos, estaria representando a "iniquidade" (v.8b), da mesma forma que o "olho deles em toda a terra" (v.6f). Embora "olho deles" pudesse ser aplicado a uma variedade de conceitos, sua interpretação como "iniquidade" tem boa sustentação porque as versões gregas e siríacas dão apoio a esta leitura, e o texto exige somente a substituição de um yod por um waw, melhorando bastante o sentido da visão, uma vez que o efá pode ser também símbolo da injustiça (cf. Am 8,5). A “iniquidade" é apenas uma personificação literária, uma maneira de dizer que "se pressente que o mal tem rosto" (Pr 11,5; 13,6; Ez 18,20; 33,12), um mal que inclui infrações civis, éticas e religiosas. Em sequência, como no hebraico "iniquidade" é uma palavra feminina, então representaria a mulher.

As ações vigorosas em que se utiliza o verbo "lançar" apontam para a mensagem de que haverá luta para combater o mal, cujo poder deve ser levado a sério. A iniquidade, subjugada e removida por duas mulheres com asas como asas de cegonha, se configura em ironia, pois Senaar seria o antigo nome da Babilônia, onde Arac e Acad (Gn 10,10) se mostraram rebeldes a YHWH (Gn 11,1-9). A casa a ser construída no exílio seria outro templo para a mulher no efá, talvez um zigurate como a Torre de Babel (Gn 11,2), mas a maldade terá de esperar até que fique pronta, para que seja colocada em seu devido lugar. O passivo intensivo indica que ela não pode se defender como outros deuses na mesma situação (Is 46,1-2). Lá será adorada como um ídolo. A remoção da iniquidade foi a resposta de YHWH para a preocupação do profeta com o mal na comunidade e nas pessoas.

\footnotetext{
${ }^{17}$ Cf. J. G. BALDWIN, Ageu, Zacarias e Malaquias, introdução e comentário. São Paulo: Vida Nova, 1972, p. 103-105.
} 
No entendimento de W. Rudolph (1976), ${ }^{18}$ Zc 5,5-11 denuncia os pecados em geral da comunidade, não sendo, portanto, questão apenas de idolatria e medida injusta. O conjunto o "olho deles" (עינָם), no v. 6f, seria a "iniquidade deles", em conformidade com a leitura da LXX. A mulher dentro de um efá, vasilha onde não caberia um ser humano em condições normais, remete a espíritos e demônios que mudam de figura, o que possibilitaria a imagem. O fato de o efá ser uma vasilha usada para medir cereais não tem nenhum significado na visão. Como a iniquidade é representada pela mulher, pensa-se, erroneamente, que se trata de idolatria, contudo o pecado aqui é muito mais amplo, é uma atitude de rebeldia contra YHWH, uma série de pecados do povo de Israel. Pensa-se, geralmente, que a escolha da mulher para representar a iniquidade seria porque a palavra em hebraico para iniquidade é feminina, entretanto é a palavra iniquidade que foi escolhida porque se queria representar uma mulher. Nesse sentido, por trás da escolha da mulher como símbolo da iniquidade está o poder feminino de sedução (cf. Gn 3,6), podendo-se ficar livre para imaginar a mulher como uma deusa de culto pagão.

Segundo C. Jeremias (1977), ${ }^{19}$ Zc 5,5-11 trata da questão da idolatria. Zacarias remove o culto a deuses estrangeiros de origem assírio-babilônica, como a "Rainha dos Céus", que deve ser venerada no lugar de onde ela veio e a que pertence. A iniquidade está relacionada com o "olho" da terra em Israel, em referência ao comportamento humano rebelde a YHWH, inerente ao povo da aliança. Zacarias pode ter sido influenciado por Ezequiel, contudo, enquanto este último consegue, mesmo no exílio, passar uma imagem positiva de superação de coração de pedra por um de carne, dádiva do espírito novo de YHWH que provoca a obediência à lei, o primeiro não consegue falar positivamente para mudar o comportamento de Israel.

O profeta Zacarias utiliza imagens de Ezequiel para falar da remoção de impurezas, necessária para uma boa relação do ser humano com YHWH. A "iniquidade" (v.8b), como comportamento humano contrário à lei e à justiça, é uma referência ao "olho deles em toda a terra" (v.6f), à terra de todo o Israel do pós-exílio. A mulher no efá representa uma deusa pagã, e essa representação da

\footnotetext{
${ }^{18}$ Cf. W. RUDOLPH, Haggai - Sacharja 1-8 - Sacharja 9-14 - Maleachi, Mit einer Zeittafel von Alfred Jepsen. Gütersloh: Gütersloher Verlagshaus Gerd Mohn, 1976, p. 118-121.

${ }^{19}$ Cf. C. JEREMIAS, Die Nachtgesichte des Sacharja. Göttingen: Vandenhoeck \& Ruprecht, 1977, p. 194-200.
} 
iniquidade pode ter por trás uma abordagem feita pelos profetas Ezequiel e Jeremias, a partir de fatos específicos. Ezequiel denuncia a adoração de deuses ao lado de YHWH (cf. Ez 36,25-38) e Jeremias denuncia a adoração à "Rainha dos Céus", responsável pela catástrofe de 587 a.C. (cf. Jr 44,17-19).

Para D. L. Petersen (1984), ${ }^{20}$ o efá (v.6d) é revelado como a "iniquidade deles em toda a terra" em referência ao "olho deles em toda a terra" (v.6f). O efá é uma unidade de medida de grão seco (cf. Rt 2,17; Lv 5,11; $1 \mathrm{Sm} \mathrm{17,17)} \mathrm{que}$ deveria conter uma quantidade acordada. Há recomendações para o uso justo do efá (cf. Dt 25,14.15; Am 8,5; Pv 20,10; Lv 19,36), e o profeta parece preocupado com a questão ao perguntar ao mensageiro: “Que é aquilo?" (v.6a). De fato, o efá injusto era utilizado no antigo Israel (cf. Ez 45,10; Mq 6,11). Desta forma, o efá

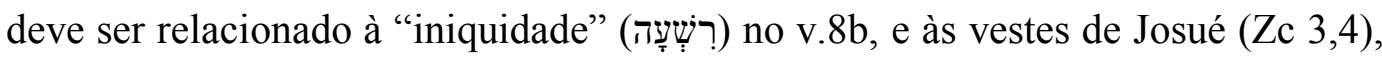
em que a iniquidade é objetivada e transferível. Esta iniquidade seria o resultado de uma transgressão, que não adere ao transgressor necessariamente. O sumo sacerdote poderia suportar a transgressão do povo. YHWH removeu a mancha da transgressão de Josué que, provavelmente, se contaminou com os pecados da comunidade (cf. Zc 3,4). Apesar da purificação do sumo sacerdote, a iniquidade permanece na terra, por isso deve ser removida do transgressor e transferida para outra parte (Senaar). O efá é a iniquidade deles e, embora o texto não afirme isso, esta conotação negativa é consistente pelo uso na tradição judaica.

Como o efá e seu significado (iniquidade) não concluem a visão, um disco de chumbo (uma tampa) é levantado para que se veja que havia uma mulher sentada no meio do efá. A imagem é extraordinária, pois um disco de chumbo não tinha usualmente este propósito e, além disso, o tamanho do efá não era capaz de conter uma mulher. O efá significa culpa e a mulher iniquidade (v.8b). O uso de iniquidade sugere que não se deve pensar que o profeta esteja simplesmente reafirmando um ponto anterior, mas que uma nova questão se apresenta. $\mathrm{O}$ substantivo "iniquidade" (רְשְׁעָה) ocorre regularmente como um antônimo do substantivo "justiça" (צְִֶ), e pode se referir a ação imprópria no campo social. O

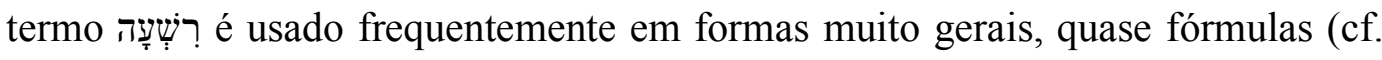
Dt 9,4; Pr 13,6). Iniquidade seria, por exemplo, uma impropriedade religiosa, não necessariamente relativa ao culto (cf. Ml 3,18).

\footnotetext{
${ }^{20}$ Cf. D. L. PETERSEN, Haggai and Zechariah 1-8, p. 254-263.
} 
Em Ezequiel, a justiça não é garantia perpétua (cf. Ez 33,12) e a vida deve

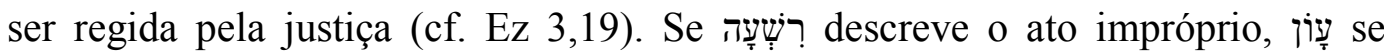
refere à culpa pelo pecado. O efá com a mulher dentro (v.7b) representa o total dos atos indevidos e suas consequências, facilitando ao profeta visualizar a totalidade dos erros e perceber como podem ser removidos. Os elementos de $\mathrm{Zc}$ 5,5-11, como as vestes de Josué em Zc 3,3-4, servem para objetivar o mal e sua contaminação e permitem ver que é possível a remoção da iniquidade e da culpa. Assim como o efá serve para simbolizar a culpa, por causa da questão da medida injusta, a mulher e o disco ou peso de chumbo poderiam também simbolizar a iniquidade. O fundamento estaria em Gn 3, com Eva, e em Gn 6, com as filhas dos homens, perpetradoras do pecado. O contato com a história primitiva é feito através da menção a Senaar, em Zc 6,1-15, permitindo discutir o caráter do erro humano. Talvez Gn 3 e 6, em conjunto, possam fornecer o pano de fundo da imagem da mulher como iniquidade, e a do efá como culpa.

Após a apresentação da cena do efá, o mensageiro lança a mulher para dentro do efá e lança a pedra de chumbo na sua abertura (vv.8c-d). Aparentemente, o efá deve conter o mal que, até aquele momento, não havia sido fechado. A tampa do efá, primeiramente designada disco (v.7a), agora é designada pedra (v.8d), podendo significar peso (cf. Pr 11,1; 16,11;20,23; 2 Sm 14,26). É importante observar que, em vários textos, efá e pedra têm o sentido de medida e peso em referência à injustiça social. Em Mq 6,10-11, o termo רְׁ é da mesma

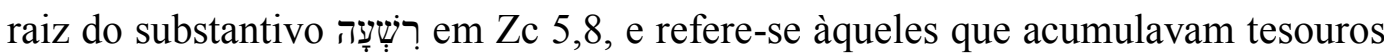
por intermédio de pesos e medidas injustos, tidos como "iníquos". Portanto, a pedra e o chumbo fazem sentido como peso, o que é comprovado pela arqueologia que encontrou pesos metálicos e de pedras em escavações no AOP.

A pedra de chumbo e o efá, juntos, servem para criar a imagem de injustiça das relações sociais desonestas, e até mesmo perversas. O disco de chumbo tem a função pragmática de conter a iniquidade e, junto com o efá, simbolizar práticas sociais indevidas que resultam em iniquidade. Efá e pedra de chumbo formam uma imagem poderosa e complexa de símbolo do mal, pois ao mesmo tempo que simbolizam a iniquidade contêm a iniquidade personificada na mulher. Efá e pedra de chumbo precisam ser removidos, uma vez que os dois contêm a culpa, o efá também representa o mal. O mal, representado pelo efá e pela culpa que contamina, pode ser isolado. O efá, a pedra de chumbo e a mulher 
personificam, respectivamente, a iniquidade, a impureza e o mal presos no efá como se fossem grãos de trigo.

M. M. Pazdan (1989) ${ }^{21}$ entende "uma mulher sentada no meio do efá" (v.7b) como representação da iniquidade (v.8b), e a "casa" (v.11b) a ser construída para o efá em Senaar um santuário. O efá e a mulher são a chave da interpretação da visão, um é o recipiente e o outro o conteúdo. O efá é uma vasilha (cf. Rt 2,17) e unidade de medida padronizada (cf. Am 8,5; Ez 45,10). A pergunta do profeta, "o que é aquilo" (v.6b), refere-se ao conteúdo, que é logo esclarecido como a "iniquidade deles em toda a terra" (v.6f). A origem de toda a iniquidade é a mulher, símbolo do mal cercado de culpa, mas, diferentemente do gênio da garrafa e de Pandora e sua caixa, a iniquidade está presa, sob controle, fechada no efá com um disco ou pedra de chumbo lançado em sua abertura. A mulher personifica a iniquidade porque, em geral, é associada ao pecado de Israel, pela metáfora da prostituição (cf. Jr 3,8; Os 1,2; Ez 16,1-63), ou por causa da queda no jardim (cf. Gn 3,1-13).

M. Butterworth (2009) ${ }^{22}$ entende que Zc 5,5-11 mostra como YHWH trata o pecado. Enquanto Zc 5,1-4 se concentra no juízo divino, Zc 5,5-11 se concentra na purificação da terra com a remoção do pecado. O efá, uma medida de grão seco, foi ampliado na visão para conter uma mulher sentada no meio dele. O conjunto "iniquidade deles" faz mais sentido que o "olho deles", principalmente por ser sustentado pela LXX e pela Siríaca. O efá talvez tenha sido escolhido por causa das citações como medida injusta (cf. Am 8,5). A mulher sentada no meio do efá é a iniquidade, embora ela não represente a iniquidade mais que o homem, a escolha se deveu por ser uma palavra feminina.

M. J. Boda (2016), ${ }^{23}$ mais recentemente, junta Zc 5,5-11 com a visão antecedente e reparte-as em Zc 5,1-4, Zc 5,9-11 e Zc 5,5-8, esta última sendo uma transição entre as duas primeiras. Através desta tripartição, vê-se em Zc 5,5-11 uma questão dupla de idolatria e de injustiça nas relações comerciais. Zc 5,1-4 e Zc 5,9-11 seriam duas cenas sequenciais com elementos comuns, ambas com

${ }^{21}$ Cf. M. M. PAZDAN, "Zacarias". In: D. BERGANT; R. J. KARRIS (orgs.), Comentário bíblico, v. 2. São Paulo: Loyola, 1989, p. 155-167.

${ }^{22}$ Cf. M. BUTTERWORTH, "Zacarias". In: D. A. CARSON; R. T. FRANCE; J. A. MOTYER; G. J. WENHAM (orgs.), Comentário bíblico Vida Nova. São Paulo: Vida Nova, 2009, p. 13081309.

${ }^{23}$ Cf. M. J. BODA, The Book of Zechariah: The New International Commentary of the Old Testament. Michigan / Cambridge / Grand Rapids: Eerdmans Publishing Company, 2016, p. 340355. 
fórmulas introdutórias idênticas ("então levantei meus olhos e vi”), com a partícula הִ dando início à descrição das cenas.

A introdução (v. 9a-b) indicaria que Zc 5,5-8 é um relato de transição utilizado para revelar o foco da visão no final. Zc 5,1-4 e Zc 5,9-11 apresentam voando objetos que não voam, em Zc 5,1-4, o rolo de pergaminho, em Zc 5,9-11, o efá. Na primeira, o objeto causa a destruição de casas; na segunda, voa para uma casa em construção. Zc 5,5-8, entre as duas cenas, interpreta a ocorrência do desfecho em Zc 5,9-11. O mensageiro e o efá "saem"; as duas mulheres com asas de cegonha também "saem" e levantam o efá em movimento semelhante ao do rolo (cf. Zc 5,3), em provável referência à saída da área do Templo. Influenciado por Ezequiel (cf. Ez 8,5), Zacarias denuncia a idolatria, indicando como o efá será removido da terra de Israel com a consequente revitalização do espaço destinado para YHWH.

O destino da maldição, na primeira cena (cf. Zc 5,5-8), é a casa de um culpado particular em algum lugar da face de toda a terra (cf. Zc 5,3); na segunda (cf. Zc 5,9-11), o destino do efá é um santuário na terra de Senaar (cf. Zc 5,11). O efá é identificado como determinada medida seca, usada no comércio e nas ofertas no culto. As inúmeras referências ao efá, como medição injusta (cf. Dt 25,14; Pr 20,10; Ez 45,10-11; Am 8,5; Mq 6,10), conectam-no aos temas de Zc 5,1-4 e Zc 5,5-11 em relação ao comércio e ao Templo. Algumas evidências apontariam o efá como imagem de um santuário: a) o contexto anterior (cf. Zc 4,1-5) em que uma menorah era usada, remetendo a um utensílio do santuário; b) o disco ou pedra de chumbo em Zc 5,5-8 utilizado para capturar a mulher no efá, sugerindo uma área do Templo onde ocorria a pesagem das ofertas; c) o conteúdo do efá, que parece ser melhor compreendido como um ídolo ou uma deusa, no contexto de santuário e não no de ambiente rural; d) o destino do efá é um santuário na Babilônia (cf. Zc 5,10-11).

A imagem do "olho deles em toda a terra" (v. 6f) seria a descrição do significado do efá, encaixando-se perfeitamente no contexto literário de "culpa" (Yָi), ligado à figura da mulher como símbolo de algo ilícito, conforme foi interpretado pela LXX e pela Peshita. Causa estranheza o sufixo de o "olho deles"

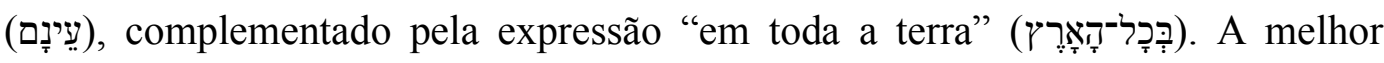
opção seria tomar o sufixo de "olho" como objetivo e não possessivo, denotando o objeto da ação vista subjacente a este substantivo (o "olho deles [que vê])". Há 
uma ligação entre "olhos" e divindade em todo o AOP: a) o "Eye Temple", templo escavado em Tel Brak (Síria), dedicado ao culto da deusa Inanna (ou Ishtar); b) a ligação que os antigos mitos egípcios faziam entre o "olho" e a deidade no olho de Horus, em que o olho lunar teria sido rasgado, permitindo que o olho solar observasse as atividades terrenas; c) a conexão entre o sol e a visão, no deus mesopotâmico Shamash (irmão de Innana), que podia ver tudo e conhecer os pensamentos secretos da humanidade; d) os olhos de Enlil, que são elogiados porque examinam a palavra inteira.

Assim, este olho que tudo vê teria um ponto de vista universal "em toda a terra" (v.6f), como o olho de YHWH (cf. Zc 4,14). O efá, com a divindade em seu interior, seria, portanto, comparado ao "olho que tudo vê" e, assim, vê o mal que será removido para seu lugar de origem na Babilônia. A mulher sentada no meio do efá (v.7b) é identificada com a "iniquidade" (רְשְָׁׁ) no v.8b. Contudo, como o efá é removido para um pedestal em um santuário na Babilônia, é mais provável que a mulher seja uma deusa ou um ídolo.

O uso do chumbo como material da tampa parece ideal no contexto da visão, pois além de ser o menos valioso dos metais, "disco" ( ) (צֶ) no v.8 têm conotação de "peso", e em conexão com pedra e efá, refletem transação comercial (cf. Lv 19,35-36, Dt 25,13-15, Mq 6,10-11) e utilização no santuário (cf. Ex 38,24-25, Lv 5,15, Nm 7,13). Assim, o autor liga o efá às duas visões (Zc 5,1-4 e Zc 5,5-11), e imputa a esta última os sentidos de idolatria e de práticas injustas no comércio.

\section{Sintese}

Alinhados com a leitura da LXX, que lê o "olho deles em toda a terra" (v.6f) como a "iniquidade deles em toda a terra", J. G. Baldwin, W. Rudolph, C. Jeremias, D. L. Petersen, M. M. Pazdan e M. J. Boda interpretaram a mulher (v.7b) como uma deusa e, portanto, símbolo da iniquidade (v.8b). Neste caso, Zc 5,5-11 é claramente considerada uma denúncia de idolatria.

W. Rudolph vai além e atribui à mulher também o poder de sedução (cf. Gn 3,6), uma imagem que remete a espíritos e demônios, e afirma que a escolha não se deu por ser iniquidade palavra feminina em hebraico, e sim pelo conteúdo do efá ser uma mulher. 
D. L. Petersen, por sua vez, amplia os pecados da comunidade por causa do mal inerente ao comportamento humano e, por isso, a iniquidade (v.8b) não seria reafirmação de um ponto anterior, mas uma nova questão sobre injustiça social relacionada com o efá (v.6d), o disco (v.7a) ou pedra (v.8d), ambos de chumbo.

M. Butterworth considera a mulher (v.7b) um símbolo da iniquidade (v.8b), mas se mostra totalmente vago sobre que tipo de pecado deva ser atribuído a ela, apenas especificando que foi escolhida porque iniquidade em hebraico é uma palavra feminina.

Neste grupo, apenas D. L. Petersen se estende na análise do material utilizado para a tampa (chumbo), um símbolo poderoso da iniquidade. Para W. Rudolph, disco (v.7a) ou pedra (v.8d), ambos de chumbo, indicam que a mulher representa alto grau de periculosidade. Os demais estudiosos do grupo não tecem comentários a respeito destes elementos.

\section{c) Estudos que implicitamente seguem a LXX}

Há autores que interpretam "uma mulher" como representação da iniquidade, e o sentido de Zc 5,5-11 como de idolatria, conforme se pode verificar abaixo.

Segundo J. H. Jr. Gailey (1962), ${ }^{24}$ o sentido de Zc 5,5-11 é de idolatria devido ao mal associado à adoração de deuses cananeus no passado, durante o exílio, e a iniquidade é simbolizada por uma mulher por causa das abstrações em hebraico que, em geral, são femininas.

M. Delcor (1975) ${ }^{25}$ entende que uma punição como a de Zc 5,5-11 seria estranha ao mundo judaico, mas examinada a situação na perspectiva do mundo hitita faria mais sentido. Não há lógica em ser o efá um meio de punição, a não ser que se entenda que o povo do pós-exílio seria punido através do instrumento com que transgrediu os preceitos da lei de YHWH.

Antes mesmo de a mulher aparecer sentada no efá, o profeta já indicou seu significado: "Esta é a iniquidade deles em toda a terra" (v.6f). Na visão, a

${ }^{24}$ Cf. J. H. GAILEY Jr., “Zechariah”. In: The Layman's Bible Commentary: Micah, Nahum, Habakkuk, Zephaniah, Haggai, Zechariah, Malachi, v. 15. Richmond / Virgínia: John Knox Press, 1962, p. 110-111.

${ }^{25}$ Cf. M. DELCOR, “La vision de la femme dans l'épha de Zach”, p. 137-145. 
iniquidade é simbolizada por uma mulher, que é encerrada no efá, e não os iníquos. Contudo, essa punição era estranha ao povo judeu. Os julgamentos hititas previam punição desse tipo e, entre todos os relatos conhecidos, o que mais se aproxima de Zc 5,5-11 seria o do demônio do mal (tarpin), que é aprisionado em um caldeirão com tampa de chumbo. Não há intenção em demonstrar uma influência hitita sobre o profeta Zacarias, o que é muito difícil de fazer, mas certamente isso aconteceu, indiretamente, através dos reinos canaanitas ou arameus. É possível que as práticas legais hititas tenham sido conhecidas em Israel muitos séculos após terem sido registradas por escrito, "pois o direito é conservador por natureza".

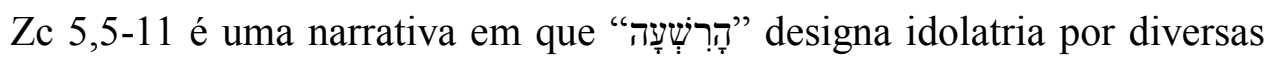
razões: a) idolatria era uma forma de iniquidade; b) os profetas a apresentam sob forma de prostituição, sendo normal ser representada por uma mulher; c) " está determinada, é "a iniquidade" por excelência, ou seja, a idolatria que ainda era praticada no pós-exílio (cf. Ez 8,14; Is 57,5; 65,1; 66,17; Ml 2,11), e que, em

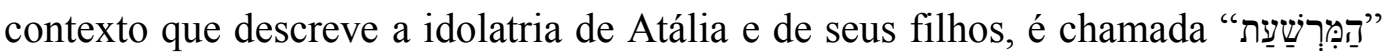
(cf. 2Cr 24,7).

Como a idolatria é removida para Senaar, e uma "casa" (templo) é construída para a mulher no efá (v.11b), tudo leva a crer que esta deusa é Ishtar. Provavelmente os que retornavam a Jerusalém haviam se contaminado no exílio e, por isso, a mensagem do profeta Zacarias é endereçada a eles, principalmente os que retornaram da Babilônia. Havia necessidade de purificação, a exemplo do que

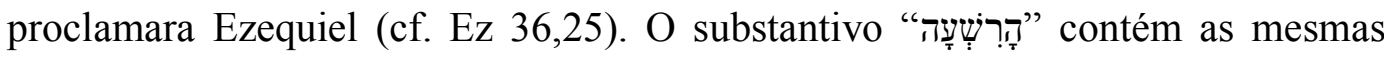

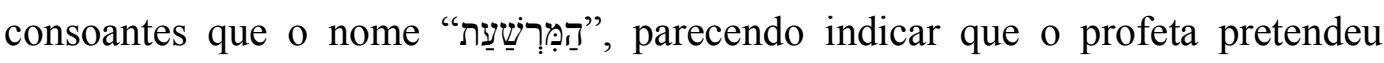
ridicularizar a divindade com a utilização deste vocábulo.

R. Mason (1977) ${ }^{26}$ faz uma relação entre o "efá" e a "culpa" à luz da nova aliança e a partir da compreensão de o "olho deles em toda a terra" (v.6f). A

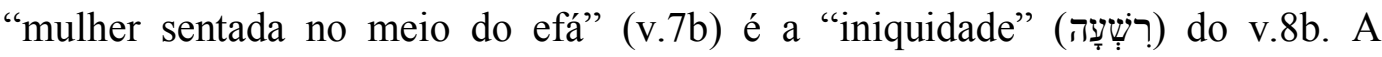
comunidade será purificada com a remoção da mulher, da mesma forma que o povo precisou ser purificado de sua contaminação pelos povos estrangeiros no

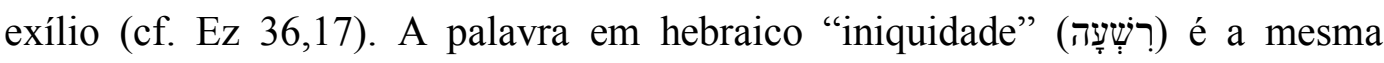
utilizada para falar do julgamento de YHWH contra aqueles que quebram os

\footnotetext{
${ }^{26}$ Cf. R. MASON, The book of Haggai: Zechariah and Malachi. Cambridge / London / New York / New Rochelle / Melbourne / Sydney: Cambridge University Press, 1977, p. 56-58.
} 
termos da aliança (cf. Dt 29,23-27). Em Zc 5,5-11, a condição do povo seria comparada a uma situação de impureza ritual, que necessitaria da remoção do indivíduo do convívio comunitário. Com YHWH presente no Templo, a aliança será renovada e Canaã será purificada da contaminação pelos pecados dos que quebraram a aliança.

R. L. Smith $(1984)^{27}$ desenvolve a ideia de que o espaço onde se passa a visão de Zc 5,5-11 seria o pátio do Templo e que ela teria conotações cosmológicas. Zc 5,1-4 e Zc 5,5-11 tratam de purificar a terra dos pecados e dos pecadores. Na primeira, os pecadores terão suas casas destruídas; na segunda, a iniquidade personificada será removida para a Babilônia para ser venerada. Embora o texto não afirme que a iniquidade é representada por uma mulher, há dados que confirmam isso: a) a palavra em hebraico para iniquidade é feminina; b) Zacarias simplesmente segue profetas anteriores, que identificaram a "iniquidade" com idolatria e a apresentaram sob a figura da prostituição (cf. Os 2,2; Jr 23,1; Ed 16,1); c) as palavras de Ezequiel são uma pista para o uso da mulher na representação do mal (cf. Ez 36,17); d) há uma indicação em uma passagem em Jeremias onde a "Rainha do Céu", uma divindade babilônica, era venerada pelas mulheres de Judá após a destruição de Jerusalém (cf. Jr 44,17-19). O efá, pelo seu tamanho, não é um lugar normal para abrigar uma mulher, por isso ela deve ser uma deusa, a deusa da fertilidade, aprisionada em seu interior. A iniquidade, personificada por uma mulher, é removida.

Para W. MacDonald (1989), ${ }^{28}$ a mulher e o efá seriam representações de religiões idólatras e mercenárias na comunidade pós-exílica. O efá seria um vasilhame utilizado como unidade de medida de grão de cereais, e a mulher a personificação da "iniquidade". A tampa de chumbo sugere controle sobre a iniquidade e, apesar disso, duas mulheres levantam o efá e voam para Senaar.

G. Emmerson $(1998)^{29}$ também estabelece uma relação entre as visões Zc 5,1-4 e Zc 5,5-11, esta última preocupando-se em eliminar o mal da comunidade sem enfatizar o julgamento de transgressões individuais, como a primeira. Para G. Emmerson, a visão assemelha-se a caricaturas no estilo de charges políticas, não

\footnotetext{
${ }^{27}$ Cf. R. L. SMITH, Micah-Malachi: Word Biblical Commentary, v. 32. Waco / Texas: Word Books Publisher, 1984, p. 209-211.

${ }^{28}$ Cf. W. MACDONALD, "Zacarias". In: W. MACDONALD, CBPAT. São Paulo: Mundo Cristão, 1989, p. 788-789.

${ }^{29}$ Cf. G. EMMERSON, Prophets II: Nahum, Habakkuk, Zephaniah, Haggai, Zechariah,
} Malachi. New York / London / Toronto / Sydney / Auckland: Doubleday, 1998, p. 104-105. 
devendo ser interpretada literalmente, mas à luz de eventos ou questões polêmicas do pós-exílio. Provavelmente, a imagem da mulher representando a iniquidade está em conexão com a veneração da deusa pagã "Rainha do Céu", que as mulheres de Judá cultuavam (cf. Jr 44,25-27). O fato de a palavra "iniquidade" ser feminina em hebraico reforça essa interpretação. A imagem negativa da mulher em Zc 5,5-11 se opõe à sua personificação como Sabedoria em Pr 31,10-33.

H. Delkurt $(2008)^{30}$ aborda Zc 5,5-11 sob o ângulo dos pecados que levaram Israel ao exílio, que ainda não tinham sido expiados e necessitavam de reparação. A iniquidade de Israel e o perdão de YHWH podem ser encontrados em todo o ciclo de visões de Zacarias. As visões Zc 5,5-11 e Zc 5,1-4 abordam a questão explicitamente. Os pecados de roubo e perjúrio (Zc 5,1-4) ainda eram causas do julgamento de YHWH. Em Zc 5,5-11 é explicitada a iniquidade de Israel através do efá revelado. O mensageiro explica que o efá é "a iniquidade deles em toda a terra" (v.6f) e descreve a mulher como "a iniquidade" (v.8b). Ao igualar o efá à iniquidade, se quer insinuar que ele esteja ligado a um comportamento culposo relacionado com unidade de medida. As referências ao efá como medida injusta em textos bíblicos mostram a importância do problema para o antigo Israel, ainda mais se invocado em conexão com o nome de YHWH (cf. Pv 20,10).

H. Delkurt faz uma preleção sobre as profecias de Am 8,5 e Mq 6,10-11, que contêm crítica social, provavelmente conhecidas de Zacarias. Nestas profecias, a acusação específica de redução de medida do efá se encontra no contexto de uma acusação sem punição, mas haverá penalidade iminente imposta por YHWH. A utilização de medida enganosa, caracterizada como "maldade"

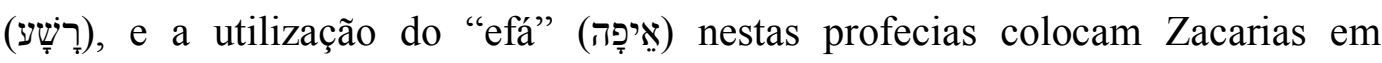
consonância com os profetas anteriores a ele.

Portanto, o efá, especialmente em conexão com “culpa" (רָוֹ) e

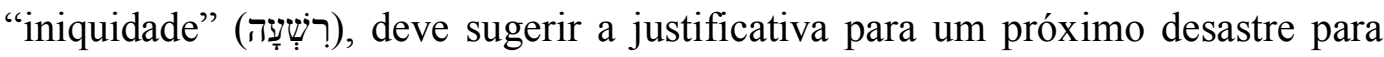
Israel (levar o efá para Senaar). Se o efá puder ser igualado a “culpa”, então, neste caso, o efá poderá ser substituído por "culpa", de modo que a idéia de "retirar a culpa" (נְשָָׁא עָוֹן) seja apresentada. Com isto, Zacarias retoma um tema clássico da

\footnotetext{
${ }^{30}$ Cf. H. DELKURT, "Sin and Atonement in Zechariah's Night Visions". In: M. BODA; J. FLOYD (orgs.) Tradition in Transition Haggai and Zechariah 1-8 in the Trajectory of Hebrew Theology. New York / London: T\&T Clark, 2008, p. 235-251.
} 
área do perdão dos pecados e apresenta-o de uma nova maneira. O sentido de Zc 5,5-11 não pode se restringir ao pecado de idolatria (ofensa ao primeiro mandamento) nem a questões exclusivamente rituais, a denúncia é, provavelmente, mais ampla e radical.

M. Hallaschka (2010), ${ }^{31}$ a partir da crítica textual de Zc 5,5-11, concluiu que a mulher no efá é uma deusa com um templo a ser construído em Senaar para onde será removida. Para ele, a visão possui uma camada básica (vv.5-6; 9-11) que recebeu adições posteriores (vv.7-8) para lhe dar sentido. Sem a adição, o v.5 se ligaria diretamente ao v.9 e o efá não seria introduzido, concluindo-se que o v.6d devia fazer parte da camada básica, sem o qual a remoção (v.11) não faria sentido. A mulher só aparece no v.7b e no v.8c, não sendo mais mencionada, o que indica que o v.9 seria uma adição. Assim, restam duas possibilidades de

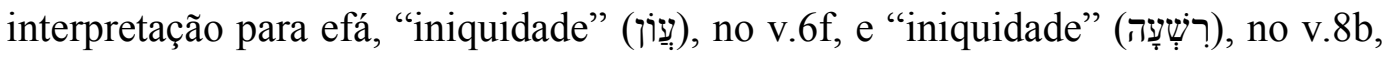
mas os dois versículos só podem ser conectados ao v.6d com uma dupla introdução. Se o v.6f é continuação do efá, o v.8b deve ser atribuído ao complemento da mulher e vice-versa. Para se saber se foi o v. $6 \mathrm{f}$ ou o v. $8 \mathrm{~b}$ que foi atribuído à mulher no vv.7ab, deve-se verificar qual deles formou a continuação original do v.6d.

As diversas formas femininas em hebraico (duas mulheres, terra, efá e iniquidade) favorecem o v.8b. A objeção a esta escolha se deve às incongruências: a) uso do gênero masculino (sufixo masculino plural) para as mulheres com asas como de cegonha (v.9d); b) o pronome pessoal masculino ("eles") em referência às mulheres que estão levando o efá (v.10b); c) o verbo "levar" (הָָָּ) no particípio feminino.

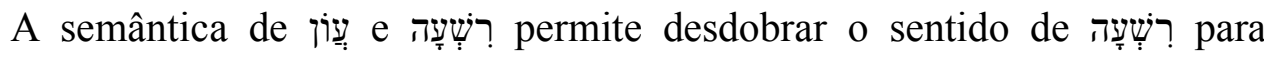
simbolizar o efá como medida enganosa. De concreto, a visão tem os pecados do efá, como medida injusta, e os relativos a ladrões e perjuros da visão antecedente (cf. Zc 5,1-4). Uma vez que tanto بִׁשְעָה podem ser compreendidos como elementos básicos de Zc 5,5-11, não se pode concluir qual dos dois foi originalmente interpretado como efá. Como os vv.9-11 correspondem a um rito de eliminação, a interpretação de بִ no v.6f, como continuação original de v.6d, oferece uma pequena vantagem na sua escolha.

\footnotetext{
${ }^{31}$ Cf. M. HALLASCHKA, Hagggai und Sacharja 1-8: eine redaktionsgeschichtliche Untersuchung. Berlin / New York: Walter de Gryter, 2010, p. 242-250.
} 
Assim, a questão da mulher nos vv.7b.8c deve ser tratada, evidentemente, como representação de uma deusa ou deuses, e não como uma mulher comum. A extensão (vv.7-8) coloca a mulher identificada como "iniquidade" no efá para ser removida para Senaar, onde terá um templo. O v.8 apenas dramatiza os acontecimentos, impedindo que a deusa fuja do efá. O culto a YHWH ao lado de uma deusa é rejeitado, por isso o v.7 transforma a visão em remoção de uma deusa. O verbo "lançar" apenas torna a cena da mulher mais dramática.

Também A. E. Hill (2012) 32 observa que, pelo pequeno tamanho do efá, a mulher sentada no meio dele só poderia ser a imagem de uma divindade. A mulher no efá representaria uma figura maligna, com pecados associados a ela. O efá, o olho deles em toda a terra e a mulher no interior do efá englobariam os pecados de idolatria que ainda contaminavam a comunidade. A imagem do disco de chumbo lançado na abertura do efá, provavelmente, enfatiza que o conteúdo deve ser mantido preso, pois o chumbo não seria um material comum para uma tampa. O espírito de idolatria fora confinado, mas ainda ameaçava a restauração da comunidade no contexto da aliança.

\section{Sintese}

Todos neste grupo, J. H. Jr. Gailey, M. Delcor, R. Mason, R. L. Smith, W. MacDonald, G. Emmerson, H. Delkurt, M. Hallaschka e A. E. Hill, consideram a visão como denúncia de idolatria. M. Delcor, cujo estudo visa a examinar a punição na perspectiva do mundo hitita, acrescenta a denúncia de injustiça social praticada na comunidade, no que é acompanhado por H. Delkurt (cf. Am 8,5; Mq 6,10-11).

R. Mason relaciona o efá (v.6d) à culpa da comunidade por prática de impureza ritual. Para R. L. Smith a visão se passa no espaço do Templo e tem conotações cosmológicas. A mulher (v.7b), interpretada como deusa, para M. Delcor seria Ishtar, para R. L.Smith e G. Emmerson, que examinam a visão em conexão com a profecia de Jeremias, seria a "Rainha dos Céus", cultuada pelas mulheres de Judá (cf. Jr 44,17-17.25-27)

\footnotetext{
${ }^{32}$ Cf. A. E. HILL, "Zechariah". In: A. E. HILL, Haggai, Zechariah and Malachi: an Introduction and Commentary, v. 28. USA / England: Inter-Varsity Press / IVP Academic, 2012, p. 166-170.
} 
Somente W. MacDonald, M. Delcor e A. E. Hill fazem algum comentário sobre os elementos da tampa do efá, o disco (v.7a) e a pedra (v.8d), ambos de chumbo. Para W. MacDonald, a tampa de chumbo sugere controle sobre a iniquidade (v.8b), que mesmo assim é levantada entre a terra e os céus (v.9f). A. E. Hill comenta apenas que o chumbo enfatiza a necessidade de aprisionar o mal. M. Delcor lembra que o chumbo foi usado por ser material conhecido no mundo antigo e ainda possuir propriedades mágicas.

\section{d) Estudos que se opõem ao entendimento da LXX}

Neste grupo, foram colocados estudiosos que não interpretam o "olho deles em toda a terra" como "iniquidade deles em toda a terra", discordando, às vezes explicita outras implicitamente, da leitura da LXX. Estas interpretações colocam o efá no centro, conforme se pode observar abaixo.

Para P. C. Craigie (1985), ${ }^{33}$ a interpretação de Zc 5,5-11 deve se orientar pela mudança de Zc 5,1-4 para esta visão. Zc 5,1-4 evoca a maldição pela quebra de dois mandamentos, centrais na relação da aliança divina com o povo. Zc 5,5-11 sai do contexto do Templo e do tema da liderança espiritual e foca sua mensagem na moral da sociedade como um todo (cf. Zc 3,1-7). A aliança continha a promessa de graça e a ameaça de maldição. O povo do retorno empenhava-se na restauração do Templo, enquanto aconteciam roubo e perjúrio no meio da comunidade (Zc 5,1-4). O efá representaria a iniquidade na comunidade pósexílica disseminada na terra toda. Haveria grandes problemas se a desobediência anulasse a bênção implícita na obra do Templo. Ao mesmo tempo, havia grande dificuldade financeira que impedia o povo de participar das obras de reconstrução, o que inclusive dava origem a lutas entre membros da comunidade.

Em meio a estas dificuldades, a lei não estava sendo aplicada com o rigor necessário, e a falta do poder judiciário levava à perversão da lei. Enquanto na visão anterior são mencionados crimes específicos (roubo e perjúrio), nesta visão, é o espírito geral da iniquidade que é personificado por uma mulher no efá. Era crescente a pobreza, e o desleixo administrativo conduzia à infração da lei. Esta

\footnotetext{
${ }^{33}$ Cf. P. C. CRAIGIE, “Zechariah”. In: P. C. CRAIGIE, Micah, Nahum, Habakkuk, Zephaniah, Haggai, Zechariah and Malachi: Twelve Prophets, v. 2. Louisville / London: Westminster John Knox Press, 1985, p. 180-184.
} 
era, provavelmente, a preocupação do profeta Zacarias que, diante da perspectiva da fé na aliança, evocou a maldição que poderia desfazer as bênçãos em andamento, a restauração do Templo e do culto.

Ben C. Ollenburger (1996) ${ }^{34}$ estabelece relações entre Zc 5,5-11, Zc 5,1-4 e Zc 2,1-4 a partir da análise do arranjo quiástico do ciclo de visões (cf. Zc 1,76,15), com as coisas que "saem" e "aparecem" nestas visões. O efá seria um objeto religioso pertencente às nações. O efá deveria ser justo, mas adulterado se configuraria em roubo. O mesmo acontece com "disco", "pedra" e "chumbo", que constituem a tampa (vv.7a.8d), e que têm, como o efá, conotação de dinheiro. Nada indica que em Zc 5,5-11 estes elementos denotem uso fraudulento, contudo as imagens sugerem o sentido de uso de medida falsa e culto pagão. $\mathrm{O}$ efá e o disco/pedra de chumbo simbolizam os efeitos corrosivos das dominações a que os judeus foram submetidos (cf. Ne 5,3.7; 9,36-37; Ag 1,6). Estes efeitos serão eliminados em Zc 5,1-4 e Zc 5,5-11. Essa relação pode ser observada quando estes elementos são levados para Senaar, junto às nações estrangeiras.

A conexão com o culto pagão pode se relacionar com os temas da injustiça, da opressão, do roubo, do perjúrio e do culto pagão (cf. Os 4,2-14; Jr 7,4-10). Portanto, além da dimensão econômica, estes elementos têm também uma dimensão religiosa e cúltica (vv.9-11). O efá abriga uma mulher identificada com a "iniquidade", ou seja, uma divindade estrangeira que será venerada entre as nações. Se o efá representa um culto pagão, era esperado que contivesse farinha para assar algo em homenagem a uma deusa. Nesse caso, a tampa (pedra/disco) serviria como uma travessa para assar (cf. Jr 44,19). O termo "disco" ou "talento"

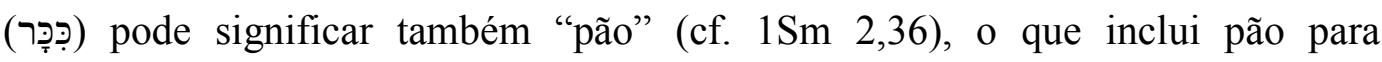
oferendas.

Ben C. Ollenburger discorda da leitura da LXX para "olho deles em toda a terra" (v.6f) porque Zc 1-8 "não contém acusações gerais". O sufixo pronominal masculino plural de "olho deles" (v.6f) refere-se a ladrão e a perjuro (Zc 5,1-4). Sintaticamente, o "olho deles" se refere ao efá e a tudo associado a ele (cf. Ez 20,8). Ladrões e perjuros (cf. Zc 5,-4) e as nações estrangeiras (cf. Zc 2,1-4) têm seus olhos sobre aquilo que lhes dá segurança (dinheiro, propriedades, poder) e, em Zc 5,5-11, estão sendo removidos da terra de Judá. Assim, a relação entre as

${ }^{34}$ Cf. B. C. OLlenburger, The Book of Zechariah: Introduction, Commentary and Reflections. Nashiville: Abingdon Press, 1996, p. 776-781. 
três visões auxilia no entendimento de Zc 5,5-11, tornando mais fácil a percepção de cada uma delas e a associação entre opressão (cf. Zc 2,1-4), roubo (cf. Zc 5,14) e efá (cf. Zc 5,5-11).

Segundo M. H. Floyd (1996), ${ }^{35}$ a leitura de Zc 5,5-11, em seu contexto literário em relação às visões Zc 4,1-14 e Zc 5,1-4, aponta para o desejo de um grupo dissidente (não reformista e não deuteronomista) de uma alternativa de vida comunitária judaica fora de Jerusalém, representada pela simbologia do candelabro e da Torá. Um dos objetos cúlticos das três visões (efá, candelabro e rolo) se tornaria símbolo do culto no Templo em reconstrução. O candelabro representa o Templo restaurado em Jerusalém, único lugar legítimo para oferecer sacrifício a YHWH, Deus único e legítimo do povo da aliança. O rolo (Torá) representa a instrução das Escrituras, principal forma de manter a comunidade baseada nas normas da aliança. O efá, ao contrário, simbolizaria um tipo de judaísmo que defende a construção de templos em lugares fora de Jerusalém e uma divindade ao lado de YHWH. A mulher no efá seria uma deusa que causaria a dispersão e não a unidade do povo de Israel.

$\mathrm{Na}$ visão, o significado do efá é antecipado pelo mensageiro e, antes mesmo de ser identificado, é caracterizado como algo que pode ser o rolo ou o candelabro (v.6f). Para embasar a ideia de um culto alternativo fora de Jerusalém, Zc 5,5-11 é comparado, primeiro com Zc 5,1-4, em seguida com Zc 4,1-14. O profeta relaciona o santuário com o mundo natural e a sociedade humana: em Zc 4,1-14, o candelabro (reservatório de óleo), Josué e Zorobabel (duas figuras humanas) e as duas oliveiras; em Zc 5,5-11 o efá (recipiente e santuário) e as duas mulheres com asas de cegonha (pertencentes tanto ao reino humano como animal). Estes elementos têm relação com a reconstrução e manutenção do Templo: as oliveiras produzem o óleo, que Josué e Zorobabel providenciam para o Templo.

A cena do efá parece imperfeita comparada com a do candelabro: a) o óleo das vasilhas e as oliveiras lembram que o óleo é necessário à vida; o efá que deveria conter um alimento, também essencial à vida, contém somente "iniquidade"; b) o servidor do candelabro se sujeita aos limites entre o humano e o

\footnotetext{
${ }^{35}$ Cf. M. H. FLOYD, "The Evil in the Ephah: Reading Zechariah 5:5-11 in Its Literary Context". In: CBQ 58 (1996), p. 51-68.
} 
não humano; o servidor do efá transgride estes limites; c) a cena do candelabro denota abundância e paz; a cena do efá denota escassez e discórdia.

Zc 5,1-4 e Zc 5,5-11 apresentam semelhanças. Na primeira, o rolo voa e sai sobre a superfície de toda a terra, e tem tamanho discrepante em relação à realidade; seu conteúdo é a lei que proíbe roubar e jurar o nome de YHWH em vão, e impõe respeito às normas da aliança. Na segunda, o efá sai e se levanta entre a terra e os céus, mostra-se discrepante em relação a seu conteúdo, uma mulher, e impõe respeito àqueles que vão adorá-la.

A cena do efá também parece imperfeita comparada à do rolo: a) o rolo pode voar sozinho porque YHWH o enviou; o efá precisa de ajuda das duas mulheres com asas de cegonha para sair do chão; b) os encarregados do rolo, que é demasiadamente grande para ser lido, suportam mais do que parece; a mulher é carregada numa vasilha muito pequena para cabê-la, que suporta menos do que parece; c) o rolo pode destruir a casa de alguém que não esteja de acordo com as normas; o efá deve passivamente depender de outros para construir uma casa (templo) para ele.

O efá, enviado para um templo (casa) em construção em Senaar, remete ao candelabro, que representa a presença divina no Templo, os "olhos de YHWH" (עיניני :יהוזה), conforme Dt 11,12. O efá faz exatamente o que o rolo faz, ele "sai" (יצָָא), e ao sair se assemelha às luzes de candelabros cujos raios "saem" (שוט) para fora do santuário. Nos três casos, a ação tem o mesmo alcance: os olhos de YHWH vagueam por toda a terra (cf. Zc 4,10), a maldição espalha-se por toda a terra (cf. Zc 5,3) e o olho deles está em toda a terra (v.6f).

O que está em questão é se o efá alcança "toda a terra", ao longo de "todo o país", e se significa algum tipo de iniquidade ou de quem é o olho. O efá simbolizaria um culto alternativo, fora de Judá. Desta forma, o $\mathrm{M}^{\mathrm{L}}$ não estaria errado caracterizando o efá (v.6d) com função cúltica na visão (v.6f), pois o "olho" estaria simbolizando o olho divino, que não precisaria de manifestação direta de poder real fora de Jerusalém, do mesmo modo que o Império Persa não precisava manifestar diretamente poder real sobre seus súditos porque mantinha uma rede de informantes oficiais e não oficiais que lhe serviam como seus olhos.

O candelabro com seus dois assistentes humanos (cf. Zc 4,14; 5,9) serve de "olhos" a YHWH, estendendo-se de Jerusalém a todo o mundo (cf. Zc 6,1-8). O efá, uma espécie de símbolo, à semelhança do candelabro e do rolo, 
representaria o que fosse imprescindível ao culto a YHWH, não necessariamente limitado a um lugar central. Assim, o sufixo pronominal masculino plural seria uma crítica aos que construíram santuários alternativos fora da terra, pensando em manter uma aliança com YHWH, promovendo rituais alternativos e, por isso, uma mulher (uma deusa) dentro do efá. O efá é o "olho deles", que será honrado como uma manifestação divina fora de Jerusalém, e o "olho" pertenceria ao grupo dissidente deste ponto de vista. De acordo com a regra gramatical hebraica, o sufixo de o "olho deles" seria referente ao substantivo precedente mais próximo, de mesmo gênero e número, ou seja, ladrão e perjuro, entendidos coletivamente.

O efá seria, portanto, a visão do olho divino sobre aqueles que roubam e juram falso, rejeitando os preceitos da Torá como base de sua identidade. O efá é símbolo dos ideais desse grupo dissidente que não se vê como parte da comunidade da aliança, da Torá e do santuário central de YHWH em Jerusalém. Nesse sentido, a mulher simbolizaria um objeto de culto com pretensões de representar o domínio real divino, mas que só pode fazê-lo de forma defeituosa. A mulher no efá representaria uma deusa para ser venerada fora de Jerusalém, reivindicando um lugar de honra ao lado de YHWH.

Para R. Hanhart (1998), ${ }^{36}$ há uma estreita relação entre as visões Zc 5,5-11 e Zc 5,1-4, percebida pelo modo independente com que a "iniquidade" é revelada na primeira: "Esta é a iniquidade deles" (v.6f). A relação é documentada claramente pelo sufixo pronominal masculino plural do v.6f em relação aos transgressores da lei, os ladrões e perjuros (cf. Zc 5,3-4), como primeira interpretação do efá, que caracteriza Zc 5,5-11 como visão independente. A culpa é o elemento de ligação das duas visões. O livro das maldições (cf. Zc 5,1-4) e o efá com a mulher (cf. Zc 5,5-11) são elementos imagéticos determinantes da essência das visões. Com o livro das maldições tem-se o juízo, e com as duas mulheres tem-se a remoção. O livro das maldições simboliza o juízo divino que persegue o efá (representa a culpa da criação) e a casa do culpado destruída diante da lei (em oposição à casa removida dos que vivem sem a lei).

O acontecimento que encerra Zc 5,5-11 apresenta forte relação com o encerramento de Zc 5,1-4, uma vez que também faz o anúncio de um juízo que se realiza para além da lei de Israel. Assim, Zc 5,5-11 deve ser interpretada em

\footnotetext{
${ }^{36}$ Cf. R. HANHART, "Dodekapropheton 7.1: Sacharja 1-8”. In: BKAT 14/7 (1998), NeukirchenVluyn, p. 19.
} 
analogia com Zc 5,1-4, com especial atenção para a pergunta do profeta pelo significado da imagem do que vê: "Que é aquilo?” (v.6b).

\section{Sintese}

Os estudiosos deste grupo, embora interpretem a mulher (v.7b) como representação da iniquidade (v.8b), dão um sentido diferente à visão: a) P. C. Craigie acredita que seja uma denúncia de injustiça social e coloca o tema da aliança no centro, relacionando Zc 5,5-11 e Zc 5,1-4; b) para Ben C. Ollenburger, o olho deles sobre toda a terra (v.6f) simboliza o olhar de ladrões e perjuros (cf. Zc 5,1-4) e das nações (cf. Zc 2,1-4) sobre o que está sendo removido de Judá, o efá (v.6d), por suas práticas ilícitas; c) para M. H. Floyd, o efá simboliza um culto alternativo não centrado no Templo de Jerusalém, colocado ao lado de símbolos legítimos do judaísmo, como a Torá (cf. Zc 5,1) e o candelabro (cf. Zc 4,2), portanto a visão seria uma crítica aos grupos dissidentes dentro da comunidade que querem construir templos alternativos fora de Jerusalém, e a mulher uma deidade que pretende um lugar de honra ao lado de YHWH; d) para R. Hanhart, Zc 5,1-4 e Zc 5,5-11 estão relacionadas uma com a outra, ambas fazendo referência à "iniquidade deles em toda a terra" (v.6f) e a culpa ligando as visões, a primeira com um juízo que destrói e a segunda com a remoção da culpa.

Todos neste grupo interpretam a mulher como iniquidade. Para M. H. Floyd, no entanto, "olho deles em toda a terra" seria referente a ladrões e perjuros (cf. Zc 5,1-4), o efá seria a visão do olho de YHWH sobre os que roubam e juram falso, rejeitando os preceitos da Torá como base de sua identidade.

\section{e) Estudos que se baseiam em intertextualidades}

A partir de uma relação com outros textos sacerdotais ou proféticos, estudiosos fazem análise de Zc 5,5-11, conforme reportam os casos abaixo.

M. Seufert (2015), ${ }^{37}$ para interpretar Zc 5,5-11, trabalha a intertextualidade entre Zc 5,5-11 e Jr 3,1-25. Para isso, oferece algumas conexões léxicas: o efá de Zacarias é a iniquidade deles "em toda a terra" (v.6f); o efá de Jeremias é a prostituição de Judá em todo lugar; o efá de Zacarias (v.6d) é o efá de Jeremias,

\footnotetext{
${ }^{37}$ Cf. M. SEUFERT, “Zechariah 5:5-11: Why an ephah?”. In: VT 65 (2015), p. 289-296.
} 
concretizado e aprisionado; a mulher sentada no efá (v.7b) é a esposa infiel (Judá), sentada pelas estradas esperando ser violada; o mensageiro lança a mulher dentro do efá (v.8c) e o homem se divorcia de sua esposa (cf. Jr 3,1.8). Em contexto mais amplo, Zacarias está preocupado com a mulher que identifica como iniquidade e que será removida para Senaar, enquanto Jeremias está preocupado com a esposa infiel de YHWH (Judá/Israel), que será removida do Monte Sião para a Babilônia (cf. Jr 3,12.14.18).

À luz de Jeremias, a mulher no efá seria uma prostituta (Judá/Israel/Jerusalém), de acordo com a tradição (cf. Ez 16; 23; Os 2; Is 50; 54; Jr 3). Um paralelo entre Zc 5,5-11 e Zc 5,1-4 deve ser observado também: o efá é levantado em voo (v.9f) e o rolo voa (Zc 5,1); ambos apresentam discrepâncias de tamanho; "em toda a terra" e "aquilo que está saindo" são linguagens comuns; uma casa será construída para a mulher (v.11b) e a maldição destrói a casa (cf. Zc 5,4). Assim, a mulher no efá seria comparada aos violadores da aliança, na visão de Zc 5,1-4, e ajudaria a fundamentar a identificação com a esposa infiel de YHWH, que agiu como uma prostituta em toda a terra. Portanto, Zc 5,1-4 seria um apelo à conversão.

Para D. Rudman (2015), ${ }^{38}$ Zc 5,1-4 e Zc 5,5-11 têm em comum uma preocupação com purificação e remoção, apresentando conexões importantes com leis sacerdotais, das quais dependem: Lv 19,11-12 (prescrição para não jurar falsamente o nome de YHWH); Nm 5,24 (maldição contida na água usada no ritual da mulher acusada de adultério, que se tornará amarga); Lv 14,44-45 (remoção dos escombros para purificação da área da casa demolida por causa da contaminação pela lepra). O efá seria o elemento de ligação da visão com os textos sacerdotais, simbolizando a iniquidade. Peculiaridades léxicas fundamentam a junção destas passagens. A perjura adúltera conecta-se com a Rainha dos Céus, que explica o porquê de a figura da iniquidade dentro do efá (a mulher) ser feminina.

O efá e o disco ou pedra de chumbo da tampa fazem referência às leis que regem pesos e medidas (cf. Lv 19,6), remetendo a ladrão e perjuro, em Zc 5,1-4, e ao efá e à mulher, em Zc 5,5-11. O conteúdo do efá (a mulher) representa o perjúrio, e o efá, o roubo. A destruição da casa de ladrão e perjuro conecta-se com

\footnotetext{
${ }^{38}$ Cf. D. RUDMAN, “Zechariah 5 and the Priestly Law”. In: SJOT 14 (2000), p. 194-206.
} 
os escombros da casa impura (cf. Lv 14,40-45), que são levados para um lugar impuro, como o efá para Senaar.

\section{Sintese}

M. Seufert estabelece um paralelo entre as visões Zc 5,5-11 e Zc 5,1-4 e as profecias de Jeremias para concluir que o efá de Zacarias (v.6f) é o mesmo efá de Jr 3,2, e está carregando a esposa infiel de YHWH (v.7b), que agiu como uma prostituta em toda a terra e será removida para Senaar (v.11b).

D. Rudman analisa Zc 5,5-11 em conexão com textos sacerdotais (Lv 14; 19; Nm 5), considerando a remoção para Senaar (v.11b) comparável; a) à remoção dos escombros da casa contaminada para um local apropriado (cf. Lv 14); b) à oferenda da adúltera perjura (cf. Nm 5,15). O efá (v.6d) e o disco (v.7a) ou pedra (v.8d), de chumbo, estariam relacionados com as leis que regem pesos e medidas (cf. Lv 19,6). A mulher dentro do efá (v.7b) remete à Rainha dos Céus, símbolo da iniquidade, e o disco e pedra de chumbo remetem à prática da injustiça em conexão com ladrões e perjuros de Zc 5,1-4.

Nenhum dos dois se detém na análise de o olho deles em toda a terra (v.6f), e apenas D. Rudman examina os elementos que compõem a tampa do efá ao usá-los para fundamentar o significado da visão.

\section{f) Estudos baseados em aspectos históricos culturais}

As dificuldades encontradas nos textos, muitas vezes levam a um ir e voltar no tempo e na história, na semântica e nas profecias anteriores, em busca de solução para o sentido de Zc 5,5-11.

E. Assis $(2010)^{39}$ é o único caso de tentativa de discernimento de um sentido para a visão baseado em aspectos sócio-religiosos. Para ele, a mulher no efá seria uma samaritana e a visão uma profecia anti-samaritana. Sua tese daria solução à tensão entre a mulher, simbolizando a iniquidade, e seu final "feliz" em uma casa na terra de Senaar, e também explicaria a representação da iniquidade por uma mulher.

\footnotetext{
${ }^{39}$ Cf. E. ASSIS, “Zechariah's Vision of the Ephah (Zech. 5:5-11)”, p. 15-32.
} 
Os samaritanos, segundo relatos bíblicos, eram os habitantes do norte de Judá exilados pelos assírios, estrangeiros da Babilônia, Cuta, Ava, Emat e Sefarvaim (cf. 1Rs 17,24), considerados "adversários" dos judeus. Com a recusa da ajuda dos samaritanos para a reconstrução do Templo, teve início um conflito entre os dois grupos (cf. Esd 3,3; Esd 4,17-21). A difícil questão da expressão o "olho deles em toda a terra" (v.6f) teria solução admitindo-se que o $\mathrm{M}^{\mathrm{L}}$ é preferível, fazendo mais sentido com a explicação de que seria o "olho" dos samaritanos que observavam para o Império Persa as ações dos judeus (cf. Esd $4,8-24 ; 5,1-6)$. A iniquidade é representada por uma mulher porque iniquidade é uma palavra feminina em hebraico.

\section{Sintese}

E. Assis (2010) tenta encontrar uma resposta para a punição sem morte e destruição em Zc 5,5-11. Para isso, interpreta o olho deles em toda a terra (v.6f) como a iniquidade deles em toda a terra, e o sufixo pronominal masculino plural de olho deles como uma referência aos olhos dos samaritanos, adversários dos judeus, que os vigiavam para o Império Persa.

A mulher no efá (v.7b) representa os samaritanos, foi escolhida como símbolo da iniquidade porque iniquidade é uma palavra feminina em hebraico. A remoção para Senaar daria fim ao conflito entre os que retornaram do exílio, e os samaritanos, que retornariam ao lugar de onde vieram e teriam o próprio Templo. E. Assis não tece comentários a respeito do efá (v.6d) nem dos elementos utilizados para tampar o efá (vv.7a.8d).

\section{2.}

\section{Hipóteses relativas a Zc 5,9-11}

Os estudiosos apresentam quase unanimidade em relação à interpretação de Zc 5,9-11, que responde a questões fundamentais para o entendimento da visão. No entanto, há menos dedicação a esta seção que à primeira (Zc 5,5-8), e o entendimento de Zc 5,5-11 é, muitas vezes, visto sem que se explique seu desfecho. Isto pode ser observado pelo menor número de interpretações de seus 
elementos, que estão apresentados abaixo, em ordem cronológica de data de interpretação.

a) duas mulheres com asas como asas de cegonha

Segundo Baldwin (1972), ${ }^{40}$ a escolha de "cegonha" (דַסִידָה) seria por causa da palavra semelhante em hebraico "aquele que é fiel" (חָָדיד), ampliando seu significado: YHWH, que guarda a aliança e, por um ato de graça, remove o mal da comunidade (cf. Zc 3,4).

W. Rudolph $(1976)^{41}$ entende que não se deve tentar encontrar um simbolismo especial para as duas mulheres com asas de cegonha. São mulheres porque transportam uma mulher, estão em dupla para poder sustentar o peso do efá com uma mulher dentro, têm asas porque precisam carregar o efá pelos ares, as asas são de cegonha porque é uma ave migratória (cf. Jr 8,7) que vence grandes distâncias e têm vento nas asas porque necessitam mover-se com o vento entrando em suas asas abertas fazendo com que acelerem o voo. Não há o menor problema de as asas pertencerem a um animal impuro (cf. Lv 11,19; Dt 14,18).

No entender de R. Mason (1977), ${ }^{42}$ as duas mulheres aparentemente não têm significado alegórico, mas é interessante notar que a palavra hebraica para

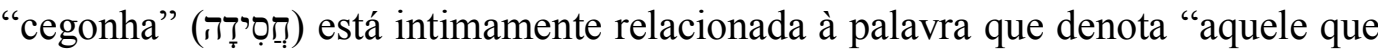
é fiel" (חָסִיד), indicando que se pretendia sugerir que os leais e dedicados na comunidade seriam purificados.

Para C. Jeremias (1977), ${ }^{43}$ as duas mulheres com asas de cegonha são seres celestiais. A imagem destes seres (v.9), que levantam o efá entre a terra e os céus (v.9), lembra Ezequiel (cf. Ez 1,5-13), onde há uma visão antropomórfica de um ser, ave e mulher, com asas, entre dois mundos intermediários, com a tarefa de transportar uma divindade com seu trono e através do ar. Fica evidente a influência do AOP em que seres mistos aparecem em representações, principalmente na Mesopotâmia, onde podem ser femininos e alados.

A escolha de cegonha pode ser porque estas aves têm asas grandes e fortes, que possibilitam voo amplo. Mas pode parecer também que houve uma tendência

\footnotetext{
${ }^{40}$ Cf. J. G. BALDWIN, Ageu, Zacarias e Malaquias, p. 103-105.

${ }^{41}$ Cf. W. RUDOLPH, Haggai - Sacharja 1-8 - Sacharja 9-14-Maleachi, p. 118-121.

${ }^{42}$ Cf. R. MASON, The book of Haggai, Zechariah and Malachi, p. 56-58.

${ }^{43}$ Cf. C. JEREMIAS, Die Nachtgesichte des Sacharja, p. 194-200.
} 
a desvalorizar estes seres híbridos, descritos como mulheres e com asas de cegonha, para afastá-los da área de atuação divina. Primeiro, quando atuam em área divina, os seres, sobrenaturais ou não, são claramente declarados como masculinos (cf. 1 Reis 22,13-28 Is 6,1), ou são descritos como completamente neutros (cf. Ez 1,5). Segundo, não se entende porque em Zc 5,5-11, em vez de descrever as asas, elas são descritas como de cegonha, o que não acontece quando há menção à águia (cf. Ex 19, 4; Dt 32,11, cf. Is 40,31). É possível que a escolha da cegonha tenha sido proposital, um animal impuro (cf. Lv 11,19; Dt 14,18), para mostrar distância da atuação da área divina.

R. L. Smith (1984) ${ }^{44}$ lembra que as cegonhas são comuns na Palestina, principalmente na primavera (março e abril), quando migram para a Europa ( $\mathrm{Jr}$ 8:7). "Cegonha" (חִִִָיָדָ) (v.9c) pode denotar também outras grandes aves de pernas compridas. A palavra pode ter ocorrido a Zacarias por causa da semelhança entre "a cegonha" (חָָסִסָיד) e "o fiel). E, embora se possa pensar que se trate de agentes divinos por causa do vento nas asas, considerado Espírito de YHWH, é bom lembrar que as cegonhas são consideradas aves impuras (cf. Lv 11,9 e Dt 14,18).

Segundo D. L. Petersen (1984), ${ }^{45}$ as duas mulheres com asas de cegonha, com vento em suas asas, que as levam para um reino intermediário, executam tarefa como agentes de YHWH (cf. Gn 8,1, Ex 15,10; Jr 10,13; Num 11,31). No espaço entre a terra e o céu, o mal não contamina o céu, nem a morada divina, nem a esfera humana, e ainda permanece sob controle de YHWH, que não toca o mal e a culpa, antes remove-os com seu poder. É importante que a remoção ocorra no reino intermediário, o que requer seres especiais. A escolha de um ser feminino não é incomum, sendo adotada em representações iconográficas do AOP. O incomum é as asas serem de cegonha, um animal considerado impuro (cf. Lv 11,19; Dt 14,18), apesar de voar alto (Jr 8,7) e levantar o efá entre a terra e o céu e ainda removê-lo para Senaar. Cegonha era uma ave singularmente adequada para executar a tarefa de remover o mal, e com isso fazer a purificação da terra e da sociedade, em processo de restauração (cf. Zc 3,1-10).

\footnotetext{
${ }^{44}$ Cf. R. L. SMITH, Micah-Malachi, p. 209-211.

${ }^{45}$ Cf. D. L. PETERSEN, Haggai and Zechariah 1-8, p. 254-263.
} 
Para C. L. Meyers e E. M. Meyers (1987), ${ }^{46}$ as duas mulheres com asas de cegonha não são querubins, pois nos textos bíblicos estes são seres masculinos, relatados como defensores da arca (cf. Ex 25,18-22) e do Templo (cf. 1Rs 6,2328), e que fornecem um trono para a glória e presença de YHWH (cf. 1Sm 4,4; 2Sm 6,2). As imagens das duas mulheres com asas de cegonha, transportando o efá (santuário), e da mulher (uma deusa) se encaixam tanto nas artes do AOP, que apresentam figuras semelhantes ladeando uma divindade e seu santuário, como nos textos bíblicos que descrevem extraordinários seres divinos (cf. S1 18,11;2Sm 22,11; Ez 1,5-28).

As asas das duas mulheres fazem parte dessas imagens mitológicas do mundo antigo, frequentemente identificadas como seres antropomórficos. As asas apresentam funcionalidade que proporciona mobilidade, e a repetição do vocábulo "asas" enfatiza isso (v.9e) com o auxílio dos verbos "sair" (v.9c) e "levantar" (v.9f). Assim, verifica-se que ao dissociar as duas mulheres com asas de cegonha dos querubins, outro problema foi criado, pois sendo os querubins do gênero masculino, seriam potentes e poderosos, enquanto as mulheres com asas de cegonha não teriam condições de carregar o efá e a mulher. Os seres híbridos são do gênero feminino para: a) associar a figura de uma mulher a ser transportada no efá; b) se dissociar dos querubins, típicos do culto javista, que não seriam adequados para transportar a iniquidade; c) tornar melhor a metáfora, levando em consideração que uma imagem positiva da cegonha viria do comportamento da fêmea da espécie. As mulheres com asas de cegonha seriam, portanto, agentes de YHWH e uma grande ironia.

M. M. Pazdan (1989) ${ }^{47}$ lembra que a cegonha é um animal impuro (cf. Lv 11,19; Dt 14,18), contudo, em Zc 5,5-11, voam (cf. Jr 8,7), levantam e removem a mulher e o efá, a iniquidade e a culpa, para habitar fora de Judá.

T. McComiskey $(1992)^{48}$ entende que as duas mulheres com asas de cegonha simbolizam a libertação.

No entender de C. Uehlinger (1994), ${ }^{49}$ as asas de cegonha indicam um animal carinhoso com a cria (embora toda ave seja), o que remete a pessoas fiéis e confiáveis (חָסִיז). Certamente a palavra tem a ver com aves migratórias que

\footnotetext{
${ }^{46}$ Cf. C. L. MEYERS; E. M. MEYERS, Haggai, Zechariah 1-8, p. 309-316.

${ }^{47}$ Cf. M. M. PAZDAN, "Zacarias", p. 155-167.

${ }^{48}$ Cf. T. E. McCOMISKEY, "Zechariah”, p. 1099-1104.

${ }^{49}$ Cf. C. UEHLINGER, "Die Frau im Efa", p. 93-102.
} 
cuidam bem dos filhotes e sabem o tempo de migração, e que certamente levarão o mal para bem longe e não retornarão de repente, em oposição a Israel, que desrespeita a lei de YHWH (cf. Jr 8,7).

Para Ben C. Ollenburger (1996), ${ }^{50}$ não está claro o porquê de duas mulheres na remoção, e a descrição de Jeremias do culto à "Rainha dos Céus" pode fornecer uma pista. O culto envolvia famílias (Jr 7,10-18), mas as mulheres, particularmente, parecem ter tomado a iniciativa nesse culto $(\mathrm{Jr} 44,15.19)$. O livro dos Reis pode fornecer outra pista através do catálogo de objetos ilícitos que Josias retirou do Templo, que faz referência a mulheres (aparentemente parte do pessoal do Templo) que estavam tecendo casas para Aserá (cf. 2Rs 23,7). Provavelmente o efá, para uso em santuários domésticos, seria uma cesta trançada ou tecida, uma casa (cella) para a divindade.

Segundo M. H. Floyd (1996), ${ }^{51}$ YHWH não age para construir cultos pagãos e instalar imagens idólatras, mas sobre as consequências da idolatria praticada por aqueles que cultuam tais imagens. Nesse sentido, não se poderia dizer que as duas mulheres com asas de cegonha sejam agentes de YHWH. Agentes divinos agem para realizar algo por YHWH, e o objetivo da remoção é instalar o efá (santuário) com uma mulher (deusa), o que implicaria YHWH ser fundador e patrono de um culto idólatra. Se Zc 5,5-11 é uma crítica a cultos pagãos, então essa crítica não se baseia na suposição de que o reino divino não pode se manifestar na forma feminina.

Pelo contrário, a visão mostra que uma imagem feminina pode representar o domínio real de YHWH e até participar, de alguma forma, da representação de seu reinado entre a terra e os céus. Se as mulheres desempenham papéis inversos aos papéis dos homens, então o efá seria uma inversão do candelabro e do rolo (Torá), e os personagens de Zc 5,5-11 seriam inversões femininas dos personagens de Zc 4,1-14 e Zc 5,1-4. Estas inversões seriam o material da sátira da visão e não a base sobre a qual a adoração de uma deusa pagã é desqualificada.

Segundo G. Emmerson (1998), ${ }^{52}$ as duas mulheres com asas de cegonha apenas enfatizam a presença de mais substantivos femininos na visão.

\footnotetext{
${ }^{50}$ Cf. B. C. OLLENBURGER, The Book of Zechariah, Introduction, p. 776-781.

${ }^{51}$ Cf. M. H. FLOYD, "The evil in the ephah", p. 51-68.

${ }^{52}$ Cf. G. EMMERSON, Prophets II, p. 104-105.
} 
J. Schnocks $(2008)^{53}$ entende que não está claro se as duas mulheres com asas de cegonha são servas de YHWH, pois nessa função estariam contradizendo a misoginia abrangente do texto.

M. Butterworth (2009) ${ }^{54}$ observa que "cegonha" tem a mesma raiz que "amor leal" e, talvez por isso, a escolha desta ave fosse sinal de que a purificação seria uma graça.

Para M. Hallaschka (2010), ${ }^{55}$ a escolha de cegonha para dar asas às duas mulheres seria porque essas aves migram regularmente (cf. $\mathrm{Jr} 8,7$ ), o que garantiria que o efá seria levado para longe de Judá.

E. Assis $(2010)^{56}$ propõe supor que as duas mulheres com asas de cegonha não se identificam com os samaritanos e os povos do norte, de acordo com a origem dos samaritanos pela tradição bíblica (cf. 2Rs 17, 1-22).

Segundo A. E. Hill (2012), ${ }^{57}$ a imagem das duas mulheres com asas de cegonha executando tarefa divina não ocorre em outro texto do AT, onde estes seres são sempre figuras masculinas. Não estaria claro se são seres divinos femininos, se são servos femininos de YHWH ou se são servos da mulher no efá. Melhor considerar serem servos de YHWH, submissos, removendo a iniquidade para mostrar o poder divino sobre falsos deuses. Há um contraste significativo entre o papel destas mulheres com asas de cegonha e o da mulher-iniquidade sentada no efá.

De acordo com D. Rudman (2015), ${ }^{58}$ as duas mulheres com asas de cegonha têm seu simbolismo esclarecido através de Nm 5 e Lv 14. Uma ave impura (cf. Lv 11,19) é o melhor animal para carregar a impureza da comunidade. A escolha de mulheres deveu-se porque o substantivo “cegonha" (חִִִָיזָה) é feminino em hebraico e o que está dentro do efá é uma mulher. Se quem carrega o efá impuro assume a impureza, então as mulheres podem personificar o falso juramento como acontece com a mulher no efá.

Para M. J. Boda (2016), ${ }^{59}$ a origem das duas mulheres com asas de cegonha, a do efá e a do rolo que voa teria sido a mesma, o tribunal do Templo,

\footnotetext{
${ }^{53}$ Cf. J. SCHNOCKS, “An Ephah between Earth and Heaven”, p. 252-270.

${ }^{54}$ Cf. M. BUTTERWORTH, “Zacarias”, p. 1308-1309.

${ }^{55}$ Cf. M. HALLASCHKA, Haggai und Sacharja 1-8, p. 242-250.

${ }^{56}$ Cf. E. ASSIS, "Zechariah's Vision of the Ephah (Zech. 5:5-11)", p. 15-32.

${ }^{57}$ Cf. A. E. HILL, "Zechariah", p. 166-170.

${ }^{58}$ Cf. D. RUDMAN, "Zechariah 5 and the Priestly Law", p. 194-206.

${ }^{59}$ Cf. M. H. FLOYD, "The Evil in the Ephah", p. 51-68.
} 
onde a justiça era administrada. As duas mulheres contrastam com "uma", sentada no efá, que precisam carregar. A cegonha era considerada um animal impuro, o que não significa que não poderia ser utilizada por YHWH para a remoção. É possível que a escolha se deva porque a cegonha teria poder de voar alto e levantar uma carga pesada entre a terra e o céu com suas grandes asas, no percurso de Judá à Babilônia.

Pode ser também que tenha sido por causa do hábito migratório da cegonha (cf. Jr 8,7) de voar do sul para o norte na primavera, trajeto equiparado à viagem da Babilônia para a Terra do Norte. Ou, talvez, por causa do jogo de

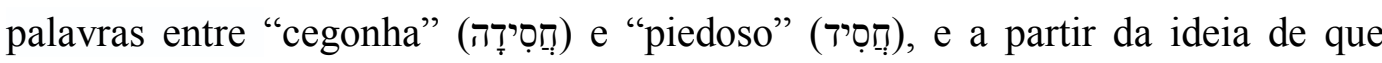
"malvado" (רָשָׁ) é antônimo léxico de piedoso (cf. 1Sm 2,9; S1 38,28; 97,10), o que torna as duas mulheres com asas de cegonha candidatas apropriadas para fazer a remoção do mal da comunidade. As duas mulheres com asas de cegonha podem ser comparadas aos querubins, o que sugere seres celestiais divinos ou executando a atividade deles (cf. Sl 18,11; 2Sm 22,11), ou aos mensageiros de YHWH no ciclo de visões do profeta Zacarias $(\mathrm{Zc} 1,7-6,15)$.

\section{Sintese}

Dos vinte e sete estudos examinados, apenas seis não exibiram algum comentário sobre as duas mulheres com asas de cegonha (J. H. Jr. Gailey, M. Delcor, W. MacDonald, P. C. Craigie, R. Hanhart, M. Seufert), o que indica que a escolha dos seres para a tarefa de remoção, do gênero feminino e com asas como de cegonha, foi considerada relevante para a interpretação da visão.

Em relação às asas, para J. G. Baldwin, R. Mason e R. L.Smith e M. J. Boda, a cegonha foi o animal escolhido por causa da semelhança entre as palavras

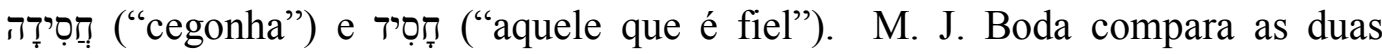
mulheres com asas de cegonha aos querubins, seres celestiais divinos com tarefas semelhantes (cf. S1 18,11; 2Sm 22,1), e ressalta o poder de voar alto das cegonhas, que com suas grandes asas podem fazer longos percursos. C. Jeremias acredita que a escolha se deu porque as asas seriam de cegonha, que são seres impuros, e afastam a tarefa da área de atuação divina.

D. L. Petersen lembra que o gênero feminino para seres híbridos não é algo incomum, pois aparecem em representações iconográficas do AOP, o 
incomum é as asas serem de cegonha, um animal impuro (cf. Lv 11,19; Dt 14,18), mas adequado porque voa alto (cf. Jr 8,7).

Para C. L. Meyers e E. M. Meyers, as duas mulheres com asas de cegonha têm relação com as figuras iconográficas do $\mathrm{AOP}$ e, embora não se tratem de querubins, o gênero feminino pode parecer inadequado, mas a escolha pode ter sido uma grande ironia. Para transportar uma mulher, melhor seria que a tarefa fosse executada por mulheres, desta forma se dissociaria também dos querubins, seres masculinos, típicos do culto javista, e ainda, melhoraria a metáfora, pois o bom comportamento da cegonha fêmea concede à imagem um aspecto positivo.

Segundo Ben C. Ollenburger, o gênero tem relação com o culto à Rainha dos Céus (cf. Jr 7,10-18), que envolvia as famílias, no qual as mulheres tinham iniciativa e participavam, tecendo santuários para divindades (cf. Jr 44,15.19; 2Rs $23,7)$.

M. H. Floyd entende que o gênero dos seres é uma maneira de o profeta mostrar que uma imagem feminina pode representar o domínio real de YHWH e, até de certa forma, participar de seu reinado "entre a terra e os céus" (v.9f). Nesse sentido, o efá seria uma inversão da Torá (cf. Zc 5,1-4) e do candelabro (cf. Zc 4,1-14).

G. Emmerson considera que os seres femininos apenas enfatizam a presença de mais elementos femininos na visão. Para J. Schnocks, a presença das mulheres contradiz a misoginia abrangente de Zc 5,5-11. A. E. Hill acredita que as duas mulheres são um tipo de "servos", embora não fique claro se de YHWH ou da mulher no efá.

W. Rudolph pensa que não se deve buscar um significado especial nas duas mulheres com asas de cegonha, pois suas características são somente requisitos necessários à execução da tarefa: são mulheres por que transportam uma mulher; são duas para que possam suportar o peso da carga transportada; têm asas para que possam carregar o efá pelos ares; as asas são de cegonha porque cegonhas são aves migratórias que vencem grandes distâncias. 


\section{b) havia vento nas asas delas}

J. G. Baldwin $(1972)^{60}$ considera que há um duplo significado para "vento" (רֵּוּ) como força e poder (cf. Zc 3,4), e assim se pode dizer que o "Espírito" de YHWH estava nas asas das duas mulheres, enfatizando a autoria divina da tarefa.

W. Rudolph $(1976)^{61}$ compreende que o vento nas asas significa que não necessitam mover-se batendo as asas, pois são impelidas pelo vento, que entra em suas asas abertas, o que lhes acelera o voo.

C. Jeremias $(1977)^{62}$ compara a cena das duas mulheres com asas de cegonha removendo o efá com a visão de Ezequiel, com seres celestiais intermediários (antropomórficos) fazendo o transporte através do ar entre dois mundos, para outro lugar (cf. Ez 1,5-28). O transporte entre a terra e os céus (v.9f) corresponde, em Ezequiel, à tempestade da vinda de YHWH (cf. Ez 1,4).

Segundo R. L. Smith (1984), ${ }^{63}$ o vento nas asas de cegonha das duas mulheres indica um voo fácil e rápido, representando um "espírito", o que sugere que a remoção se deu por obra do Espírito de YHWH. Para R. L. Smith, contudo, deve-se ter cautela e concluir com base em Lv 11,9 e Dt 14,18.

D. L. Petersen (1984) ${ }^{64}$ lembra que as duas mulheres não estão andando ou correndo, mas voando com vento em suas asas de cegonha e levantam, assim como a tampa foi levantada, o efá, entre a terra e os céus, um reino intermediário, território importante para as visões de Zacarias. Nesta área, o mal não contamina os céus, a morada divina e a esfera humana. Este reino intermediário não é o paraíso celeste, mas ainda assim permanece sobre o controle de YHWH. O vento é o agente do movimento de YHWH, que não poderia tocar o mal e a culpa causada pelo pecado, mas poderia oferecer o poder para sua remoção.

Para C. L. Meyers e E. M. Meyers (1987), ${ }^{65}$ o vento (רֵּרוּํ) está associado com o ato de voar, para descrever a maneira com que as duas mulheres com asas de cegonha vão se locomover para Senaar, ou pode significar apenas que as asas

\footnotetext{
${ }^{60}$ Cf. J. G. BALDWIN, Ageu, Zacarias e Malaquias, p.103-105.

${ }^{61}$ Cf. W. RUDOLPH, Haggai - Sacharja 1-8 - Sacharja 9-14 - Maleachi, p. 118-121.

${ }^{62}$ Cf. C. JEREMIAS, Die Nachtgesichte des Sacharja, p. 194-200.

${ }^{63}$ Cf. R. L. SMITH, Micah-Malachi, p. 209-211.

${ }^{64}$ Cf. D. L. PETERSEN, Haggai and Zechariah 1-8, p. 254-263.

${ }^{65}$ Cf. C. L. MEYERS; E. M. MEYERS, Haggai, Zechariah 1-8, p. 309-316.
} 
estivessem estendidas (cf. S1 18,10). Em ambos os casos, o vento nas asas se adapta ao dinamismo da visão.

T. McComiskey (1992) ${ }^{66}$ observa que alguma coisa chama a atenção do profeta, fazendo-o levantar os olhos e ver as duas mulheres com asas de cegonha se aproximando. O que o faz prestar atenção é o som das asas batendo com o vento que havia nelas. Com grandes asas parecidas com as de uma cegonha, essas figuras voam com o efá acima da terra, em direção aos céus.

M. Butterworth (2009) ${ }^{67}$ entende que o vento em suas asas tem o sentido de um "espírito" (cf. Zc 6,5), o que implicaria uma purificação por obra do Espírito de YHWH.

Segundo M. J. Boda (2016), ${ }^{68}$ a expressão “vento nas asas delas” (cf. 9d), que em outros textos aparece como "asas com vento", sugere que as asas possuem vento e não que o vento possui asas, como nos textos bíblicos em que o vento é identificado como servos de YHWH (cf. Gn 8,1; Ex 15,10; Sl 104,3; Os 4,19). Como as mulheres são impulsionadas pelo vento nas asas, então o vento seria o agente de YHWH e não as duas mulheres com asas de cegonha.

\section{Sintese}

Dos vinte sete estudos examinados, dezoito não exibiram comentários sobre o vento nas asas das cegonhas (C. Uehlinger, J. Schnocks, M. M. Pazdan, J. H. Jr. Gailey, M. Delcor, R. Mason, W. MacDonald, G. Emmerson, M. Hallaschka, A. E. Hill, P. C. Craigie, Ben C. Ollenburger, M. H. Floyd, R. Hanhart, H. Delkurt, M. Seufert, D. Rudman e E. Assis).

O significado deste vento nas asas de cegonha das duas mulheres é, por alguns, interpretado como ação do Espírito de YHWH, com diferentes sentidos: para J. G. Baldwin, seria a força e o poder divino; para R. L. Smith, o voo fácil e rápido da cegonha indica que a remoção se deu por obra do Espírito de YHWH; para M. Butterworth, o vento é a ação do Espírito que purifica; para C. Jeremias, que vê uma relação com a visão de Ezequiel (cf. Ez 1,5-28), é comparável à tempestade da vinda de YHYWH (cf. Ez 1,4); D. L. Petersen vê o vento atuando

\footnotetext{
${ }^{66}$ Cf. T. E. McCOMISKEY, “Zechariah”, p. 1099-1104.

${ }^{67}$ Cf. M. BUTTERWORTH, “Zacarias", p. 1308-1309.

${ }^{68}$ Cf. M. J. BODA, The Book of Zechariah, p. 340-355.
} 
em área que não é ainda o paraíso celeste, mas sob o poder e o controle de YHWH; para M. J. Boda, o fato de ser o vento nas asas e não asas com vento indica que o vento é o agente de YHWH.

De forma pragmática, C. L. Meyers e E. M. Meyers veem o vento como parte do dinamismo da visão; T. McComiskey como o som que visa a despertar a atenção do profeta; e W. Rudolph vê o vento somente com a função de acelerar o voo das mulheres com asas de cegonha.

\section{c) Terra de Senaar}

J. H. Jr. Gailey (1962) ${ }^{69}$ acredita que o nome Senaar corresponde em hebraico à antiga área entre os rios Tigre e Eufrates, ao sul da Babilônia, secularmente conhecida por historiadores como Suméria.

J. G. Baldwin $(1972)^{70}$ entende que a remoção para Senaar é ironia, pois corresponde à região onde se localizavam a Babilônia, Arac e Acad (cf. Gn 10,10), que desde os primórdios se mostraram rebeldes a YHWH (cf. Gn 11,1-9), e onde o povo de Israel estivera exilado.

Para W. Rudolph (1976), ${ }^{71}$ o nome Senaar no lugar de Babel tem caráter simbólico como o lugar em que a humanidade cometera pela primeira vez seu pecado original (cf. Gn 3,1-13) e tentara invadir a esfera divina, removendo a barreira entre YHWH e os homens (cf. Gn 11,1-9). Assim, a mulher deve ser levada de volta a esse ponto de partida do pecado da humanidade.

M. Delcor $(1975)^{72}$ acredita que a mensagem de Zacarias é dirigida aos exilados que retornaram da Babilônia, portanto Senaar seria a Babilônia, considerada a terra da iniquidade, da mesma forma que Edom para o profeta Malaquias (cf. Ml 1,1-4).

R. Mason (1977) $)^{73}$ acredita que terra de Senaar seja o nome arcaico da Babilônia, conforme o relato da Torre de Babel (cf. Gn 11,2). Na visão seria uma forma de ironia, com a idolatria relegada à Babilônia, único lugar adequado para isso.

\footnotetext{
${ }^{69}$ Cf. J. H. GAILEY Jr., "Zechariah”, p. 110-111.

${ }^{70}$ Cf. J. G. BALDWIN, Ageu, Zacarias e Malaquias, p. 103-105.

${ }^{71}$ Cf. W. RUDOLPH, Haggai - Sacharja 1-8 - Sacharja 9-14 - Maleachi, p. 118-121.

${ }^{72}$ Cf. M. DELCOR, "La vision de la femme dans l'épha de Zach", p. 137-145.

${ }^{73}$ Cf. R. MASON, The book of Haggai, Zechariah and Malachi, p. 56-58.
} 
R. L. Smith (1984) ${ }^{74}$ acredita que Senaar era o antigo nome da Babilônia (cf. Gn 10,10; 11,1), portanto, uma ironia. Os retornados da Babilônia para Jerusalém estavam, provavelmente, muito ofendidos com a idolatria na terra, por isso o que era considerado idólatra na terra santa se tornará objeto de adoração na Babilônia.

Segundo D. L. Petersen, ${ }^{75}$ Senaar é Mesopotâmia (cf. Gn 10,10; 11,2). Senaar é o local do exílio e de onde estão retornando os exilados (cf. Is 11,11). Curiosamente, a remoção é para Senaar e não para a Babilônia, talvez por causa da LXX, da Siríaca e do Targum que leram Babel, antigo nome da Babilônia, lugar do exílio e onde o erro foi perpetrado, fazendo com que YHWH, provocado, dispersasse a humanidade (cf. Gn 11). Em Zc 5,5-11, portanto, se repete a ação de enviar o povo de um território ao outro. A remoção para Senaar estabelece uma imagem negativa para a Babilônia, considerada dominadora e saqueadora de Jerusalém.

C. L. Meyers e E. M. Meyers $(1987)^{76}$ lembram que a LXX, a Siríaca e o Targum leram Senaar como Babilônia (cf. Gn 10,10; 11,2; 14,1.9; Js 7,21; Is 11,11). A escolha da Babilônia como o destino da iniquidade é quase acidental. Babilônia foi para onde os judeus foram exilados e de onde retornaram com a permissão de Ciro, rei persa.

W. MacDonald (1989) compreende que Senaar seria uma referência à Babilônia, local de origem das religiões idólatras e mercenárias de Israel.

Segundo T. McComiskey (1992), ${ }^{77}$ não há em Zc 5,5-11 qualquer conotação de que Senaar seja lugar do pecado. Se houvesse, não seria construída uma casa e preparada para o efá. Contudo, como os livros proféticos atribuem a Senaar a opressão, seria compreensível o local como adequado para a iniquidade, onde habitam a idolatria, a opressão e a crueldade.

C. Uehlinger (1994) ${ }^{78}$ entende que Senaar seria a Babilônia Meridional (cf. Gn 11,2), lugar de adoração de ídolos pagãos, região claramente externa a Judá, na perspectiva do culto.

\footnotetext{
${ }^{74}$ Cf. R. L. SMITH, Micah-Malachi, p. 209-211.

${ }^{75}$ Cf. D. L. PETERSEN, Haggai and Zechariah 1-8, p. 254-263.

${ }^{76}$ Cf. C. L. MEYERS; E. M. MEYERS, Haggai, Zechariah 1-8, p. 309-316.

${ }^{77}$ Cf. T. E. McCOMISKEY, "Zechariah”, p. 1099-1104.

${ }^{78}$ Cf. C. UEHLINGER, "Die Frau im Efa", p. 93-102.
} 
Ben C. Ollenburger (1996) ${ }^{79}$ acredita que Senaar evoca Gênesis (cf. Gn 11,2), com o povo construindo uma torre no lugar, que vem a se tornar Babel, antigo nome da Babilônia (cf. Gn 11,9). O efá evoca o culto pagão nas nações que têm a Babilônia como origem e símbolo da idolatria.

H. Delkurt $(2008)^{80}$ lembra que "Babel" é encontrada em textos bíblicos em relação à conquista de Judá pelos babilônios e ao exílio decorrente disso, enquanto o pano de fundo para as referências a Senaar só pode ser reconhecido em Dn 1,2. Como Zacarias utiliza Babel para eventos relacionados com a história contemporânea (cf. Zc 2,11; 6,10), o uso de Senaar em Zc 5,5-11 o torna impressionantemente arcaico.

Talvez a Babilônia não fosse aquela mencionada na visão. Não se entende a que Babilônia estaria sendo feita a referência. Na época das proclamações de Zacarias, Babilônia não era uma ameaça real a Judá, uma vez que havia sido subjugada pelo rei persa Ciro. Também não era mais necessário um ato de vingança, quando o próprio YHWH se vingara enviando o povo para o exílio. Não seria provável a remoção da iniquidade para a Babilônia, uma terra tão próxima de Israel, com a possibilidade de retorno a qualquer momento.

Portanto, Senaar seria o local do império de tempos primitivos, lembrado especialmente por causa de sua arrogância para com Deus, ou então haveria outra interpretação. Se Senaar se refere ao império de tempos primitivos, pode-se admitir que o mal está sendo levado para lá por causa do comportamento arrogante e pecaminoso dos primeiros tempos (cf. Gn 11,1-9). Senaar faz a conexão entre os tempos primitivos e o tempo do início de Israel, com o mal removido para um reino distante e perdido, de onde não pode retornar e ao qual pertence.

M. Butterworth (2009) ${ }^{81}$ entende que a terra de Senaar ficaria na Mesopotâmia, lugar onde Abraão deixou para fazer aliança com YHWH, e onde foi construída a torre de Babel, destruída por YHWH (cf. Gn 11,2.9). A conexão entre este acontecimento e a visão é feita pela expressão "sobre toda a terra" (cf. Gn 11,4.9; Zc 5,3).

\footnotetext{
${ }^{79}$ Cf. B. C. OLLENBURGER, The Book of Zechariah, p. 776-781.

${ }^{80}$ Cf. H.DELKURT, "Sin and Atonement in Zechariah's Night Visions", p. 235-251.

${ }^{81}$ Cf. M. BUTTERWORTH, “Zacarias”, p. 1308-1309.
} 
Na compreensão de M. Hallaschka, em vez de Babilônia (cf. Zc 2,11; $6,10)$, o profeta chamou o lugar para onde foi removida a iniquidade de Senaar por razões simbólicas: a culpa (o "olho deles"), a arrogância humana e a falta de temor a YHWH. ${ }^{82}$

E. Assis $(2010)^{83}$ acredita que Senaar seria a Babilônia, local de onde o povo de Judá acreditava que tivessem vindo os samaritanos, conforme a tradição bíblica (cf. 2Rs 17,1-23). A remoção para Senaar indicaria que os samaritanos não teriam mais ligação com o Templo de YHWH.

A. E. Hill (2012) ${ }^{84}$ compreende Senaar como uma referência à Babilônia, lugar condenado pelos profetas como de idolatria e iniquidade (cf. Is 46,47; Jr $50,51)$.

Como Seifert (2015) ${ }^{85}$ faz uma relação de Zc 5,5-11 com as profecias de Jeremias, ele lembra que, enquanto a esposa infiel de Jeremias (cf. Jr 23,10) é removida do Monte Sião para a Terra do Norte, a mulher no efá (v.7b), identificada como iniquidade (v.8b), é removida no sentido contrário, para Senaar.

Para M. J. Boda (2016), ${ }^{86}$ Senaar está associada à Babilônia (cf. Gn 10,10; 11), e pode ter relação com os zigurates mesopotâmicos e babilônicos. O verbo “construir" (בָָָָָּ), no v.11b, estaria relacionado com a construção do Templo em Jerusalém, utilizado em Zc 5,5-11 com o mesmo sentido para facilitar a remoção de toda a influência religiosa estrangeira no Templo e na terra.

\section{Sintese}

Dos vinte e sete estudos examinados, oito não fazem uma análise específica sobre a terra de Senaar (J. Schnocks, C. Jeremias, M. M. Pazdan, W. MacDonald, G. Emmerson, M. Hallaschka, A. E. Hill, P. C. Craigie, M. H. Floyd, R. Hanhart, H. Delkurt, M. Seufert e D. Rudman).

Os estudos que abordam a questão tentam localizar o território de Senaar no mapa do mundo antigo e estabelecer seu significado na visão. Assim, a terra de Senaar é localizada: a) na área entre os rios Tigre e Eufrates, ao sul da Babilônia,

\footnotetext{
${ }^{82}$ Cf. M. HALLASCHKA, Haggai und Sacharja 1-8, p. 242-250.

${ }^{83}$ Cf. E. ASSIS, “Zechariah's Vision of the Ephah (Zech. 5:5-11)”, p. 15-32.

${ }^{84}$ Cf. A. E. HILL, “Zechariah”, p. 166-170.

${ }^{85}$ Cf. M. SEUFERT, “Zechariah 5:5-11: Why an ephah?”, p. 289-296.

${ }^{86}$ Cf. M. J. BODA, The Book of Zechariah, p. 340-355.
} 
conhecida como Suméria (J. H. Gailey Jr); b) na Babilônia, em conformidade com Gn 10,10 (J. G. Baldwin, R. L.Smith, e M. J. Boda), ou em conformidade com a LXX, a Siríca e o Targum, que assim leram este nome (D. L. Petersen e C. L. Meyers e E. M. Meyers); c) em Babel (W. Rudolph); d) como terra de origem dos samaritanos (E. Assis).

A escolha de Senaar tem origem em diferentes motivos: ironizar o local dos que estão retornando e onde se pratica a idolatria (J. G. Baldwin, R. Mason e R. L. Smith); lembrar o lugar de antiga rebeldia a YHWH, dando sentido para a remoção (H. Delkurt).

\section{d) Uma casa e uma base}

J. H. Jr. Gailey (1962) ${ }^{87}$ compreende a casa providenciada para a mulher na Babilônia, a casa da iniquidade, como claramente um templo, e nela o efá e seu conteúdo seriam colocados em um pedestal para adoração.

Segundo J. G. Baldwin (1972), ${ }^{88}$ a casa que irão construir na terra do exílio seria um zigurate, como a Torre de Babel (Gn 11,2), e a maldade terá de esperar até que fique pronta, para que seja colocada em seu devido lugar.

M. Delcor $(1975)^{89}$ acredita que como é a idolatria que será exilada na Babilônia, a casa seria um templo a ser construído para uma deusa, provavelmente Ishtar, representada por uma mulher.

W. Rudolph (1976) ${ }^{90}$ afirma que construir uma casa, preparar e assentar o efá com a mulher num pedestal é uma imagem de imensa ironia, em que sobressai a voz do judaísmo piedoso, que tendo vivido no exílio vivenciara a adoração de miríade de deuses pagãos.

No entendimento de R. Mason (1977), ${ }^{91}$ a palavra hebraica para casa significa também templo, o que sugere que em Zc 5,5-11 se está falando de remoção de toda a adoração falsa e idólatra.

Para C. Jeremias (1977), ${ }^{92}$ como se trata de denúncia de um culto idolátrico, a casa seria um templo onde uma deusa (uma mulher no efá) será

\footnotetext{
${ }^{87}$ Cf. J. H. GAILEY Jr., “Zechariah”, p. 110-111.

${ }^{88}$ Cf. J. G. BALDWIN, Ageu, Zacarias e Malaquias, p. 103-105.

${ }^{89}$ Cf. M. DELCOR, "La vision de la femme dans l'épha de Zach.", p. 137-145.

${ }^{90}$ Cf. W. RUDOLPH, Haggai - Sacharja 1-8 - Sacharja 9-14 - Maleachi, p. 118-121.

${ }^{91}$ Cf. R. MASON, The book of Haggai, Zechariah and Malachi, p. 56-58.
} 
assentada numa base, de acordo com o costume na Mesopotâmia de assentamentos de imagens e símbolos de divindades.

D. L. Petersen (1987) $)^{93}$ lembra que a palavra "casa" (בָּית) tem a óbvia

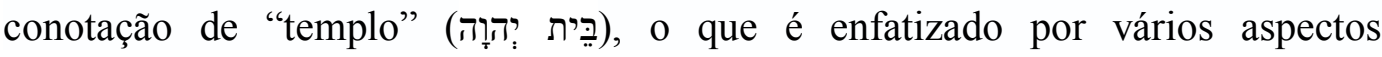

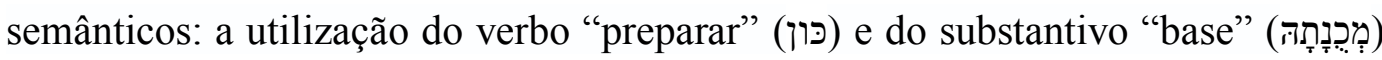
após a preposição "sobre” (עַ)); a raiz "פּון", que enfatiza fixidez. Há, portanto, uma função cultual para o efá na Babilônia (cf. 1Rs 7,27ss; Esd 3,3), e a casa seria um templo onde o que a Babilônia roubou do Templo de Jerusalém será assentado e venerado.

C. L. Meyers e E. M. Meyers $(1987)^{94}$ entendem que a casa seria um templo, uma vez que Zc 5,5-11 envolve uma questão de idolatria. A ideia seria fornecer uma residência apropriada para a divindade não javista, fora da terra de Judá. A força da imagem não está no tipo de "casa", se é um zigurate ou santuário no topo de um zigurate, mas na ideia de que a deusa (uma mulher) terá seu lugar legítimo, numa "base”, ou seja, num lugar apropriado dentro do templo.

W. MacDonald (1989) ${ }^{95}$ compreende que a casa representa um templo pagão que irá purificar Israel da idolatria, após o exílio na Babilônia.

T. McComiskey (1992) ${ }^{96}$ não deixa claro o que entende por casa em Zc 5,5-11, que estaria em conexão com Zc 13,1-6, que descreve a remoção absoluta do pecado de idolatria (o mal principal) do povo de Israel. Enquanto em Zc 13,1-6 casa e base podem ser vistas como templo e pedestal, em Zc 5,5-11 aparentemente não denotam idolatria. O mal em Zc 13,1-6 seria por desobediência à lei, e em Zc 5,5-11 seria generalizado.

No entendimento de C. Uehlinger (1994), ${ }^{97}$ a casa a ser construída é um templo. A deusa removida não será mais cultuada em Judá, e sim em países pagãos.

Para M. H. Floyd (1996), ${ }^{98}$ o desejo de alguns membros da comunidade do retorno de construir templos alternativos fora de Jerusalém é satirizado na descrição que inclui as palavras "construir", "preparar", "assentar", "casa" e

\footnotetext{
${ }^{92}$ Cf. C. JEREMIAS, Die Nachtgesichte des Sacharja, p. 194-200.

${ }^{93}$ Cf. D. L. PETERSEN, Haggai and Zechariah 1-8, p. 254-263.

${ }^{94}$ Cf. C. L. MEYERS; E. M. MEYERS, Haggai, Zechariah 1-8, p. 309-316.

${ }^{95}$ Cf. W. MACDONALD, "Zacarias”, p. 788-789.

${ }^{96}$ Cf. T. E. McCOMISKEY, “Zechariah”, p. 1099-1104.

${ }^{97}$ Cf. C. UEHLINGER, "Die Frau im Efa”, p. 93-102.

${ }^{98}$ Cf. M. H. FLOYD, "The evil in the ephah", p. 51-68
} 
"base", que fazem parte, tanto do momento vivido pela comunidade do retorno, como de alguma coerência teológica, mesmo ridicularizando a pretensão desse grupo dissidente.

R. Hanhart (1998) ${ }^{99}$ entende que, enquanto em Zc 5,1-4 o livro das maldições corre atrás da iniquidade e o juízo se realiza na destruição da casa de ladrões e perjuros, em Zc 5,5-11 YHWH remove a apostasia de Israel e, para afastá-la do âmbito sagrado de YHWH, constrói uma casa para ela além desse âmbito. Nesse sentido, a casa destruída do transgressor da lei em Zc 5,1-4 se opõe à casa a ser construída para os que vivem além da lei em Zc 5,5-11.

M. Butterworth (2009) ${ }^{100}$ compreende que a casa a ser construída pode ser um templo, o que implica a iniquidade não encontrar lugar no meio do povo de YHWH.

M. Hallaschka (2010) ${ }^{101}$ considera ter havido uma adição a Zc 5,5-11, uma extensão (7-8.11b) à visão que colocou uma deusa, identificada como iniquidade, no efá e a baniu para sempre de Judá para Senaar, onde recebeu um pedestal (base) no templo (casa).

E. Assis $(2010)^{102}$ entende que a casa a ser construída para a mulher no efá seria um templo para os samaritanos, que assim seriam afastados de Judá. A construção de um templo pagão para um povo considerado pagão não incorre em problema teológico e manteria os samaritanos afastados de Jerusalém, evitando denúncias ao Império Persa.

Para D. Rudman (2015), ${ }^{103}$ embora não haja uma conexão explícita com a questão de idolatria em Zc 5,5-11, a casa a ser construída simbolizaria um templo para o efá, que será colocado em sua base (cf. Rs 7,27; Esd 3,3). O vocábulo "base" (מְכָוֹנָ), no v.11d, refere-se a um suporte para objetos sacros, como os lavatórios, o que remete aos objetos retirados do Templo de Salomão e levados para a Babilônia (cf. 2Rs 23,13.16; Jr 27,19). A casa, portanto, seria um antitemplo a ser construído na Babilônia, para contrabalançar com o que está sendo construído em Jerusalém. Talvez houvesse a ideia de se fazer um trocadilho entre

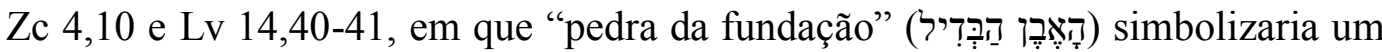

\footnotetext{
${ }^{99}$ Cf. R. HANHART, "Dodekapropheton 7.1. Sacharja 1-8”, p. 19.

${ }^{100}$ Cf. M. BUTTERWORTH, “Zacarias”, p. 1308-1309.

${ }^{101}$ Cf. M. HALLASCHKA, Haggai und Sacharja 1-8, p. 242-250.

${ }^{102}$ Cf. E. ASSIS, “Zechariah's Vision of the Ephah (Zech. 5:5-11)”, p. 15-32.

${ }^{103}$ Cf. D. RUDMAN, "Zechariah 5 and the Priestly Law", p. 194-206.
} 
anti-templo, para mostrar o erro do culto babilônico se o efá viesse a ser venerado por esse povo. Contudo, isso não significa que seu conteúdo tenha o sentido de idolatria na visão.

Segundo M. Seufert (2015), ${ }^{104}$ a construção de uma casa para o efá não se traduz em algo explicitamente positivo, mas necessariamente positivo, uma vez que não houve destruição para a iniquidade. Contudo, pode-se considerar o aspecto negativo da construção da casa se esta for relacionada com os museus encontrados em escavações no palácio de Nabucodonosor II, que exibiam prováveis exposições de saques a territórios conquistados. Estes monumentos eram do conhecimento do povo do pós-exílio e, consequentemente, também de Zacarias. Assim, ele não previu um final feliz, pois a mulher no efá se tornará uma peça de museu em Senaar, objeto de pilhagem para seus inimigos (cf. Zc 2,12).

M. J. Boda (2016) ${ }^{105}$ observa que, em outras partes de Zc 1-8, o verbo “construir" (פָָָָּּה) está relacionado com a reconstrução do Templo de Jerusalém, cujo objetivo é facilitar o retorno de YHWH à sua terra. No v.11b, este verbo é usado para construir um santuário para facilitar o afastamento de toda a influência babilônica da terra de YHWH. As mensagens iniciais de Zacarias, de preparação e esperança (cf. Zc Zc 1,5-6; 14-17), eco da mensagem de expectativa de Trito Isaías da destruição da Babilônia (cf. Is 40-48), destacam o papel do profeta como aquele que assumiu o manto messiânico no período persa inicial, à medida que as promessas divinas começavam a ser cumpridas. Os verbos "construir" (כָָָָָָ) e

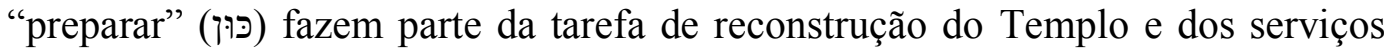
(cf. 1 Cr 22,3.5.14; 28,2; 29,2.3.19; 2Cr 2,6.8).

\section{Sintese}

Considerando que a maioria dos estudiosos interpreta a mulher no efá (v.7b) como uma deusa num santuário (C. L. Meyers e E. M. Meyers, T. McComiskey, C. Uehlinger, J. Schnocks, J. G. Baldwin, W. Rudolph, C. Jeremias, D. L. Petersen, M. M. Pazdan, M. Butterworth, M. J. Boda, J. H. Jr. Gailey, M. Delcor, R. Mason, R. L. Smith, W. MacDonald, G. Emmerson, M. Hallaschka, A. E. Hill, Ben C. Ollenburger, M. Seufert, D. Rudman), o sentido da

\footnotetext{
${ }^{104}$ Cf. M. SEUFERT, “Zechariah 5:5-11: Why an ephah?”, p. 289-296.

${ }^{105}$ Cf. M. J. BODA, The Book of Zechariah, p. 340-355.
} 
casa (v.11b) deveria ficar evidente como templo, sendo que a casa pode ter a imagem de um zigurate ou santuário (C. L. Meyers e E. M. Meyers).

Contudo, nem sempre a associação da casa com um templo aparece de forma clara nestes estudos, às vezes nem sequer é mencionada. T. McComiskey, por exemplo, relaciona Zc 13,1-6 com Zc 5,5-11 e a visão a um mal generalizado, não deixando claro o que representa a casa. Para D. Rudman, a casa é um templo, embora considere que não haja em Zc 5,5-11 uma conexão explícita com idolatria. W. Rudolph, para quem a mulher remete à imagem de sedutora, não esclarece o sentido da casa na visão. Para M. Seufert, a casa seria uma espécie de museu, semelhante ao encontrado em escavações no palácio de Nabucodonosor.

Poucos estudiosos se preocupam com o significado da base sobre a qual o efá será assentado na visão (v.11d). Para D. L. Petersen, a base serve para enfatizar a conotação de templo. Para T. McComiskey, o "assentar em sua base" passa um sentido de finalidade. Para M. H. Floyd, os verbos construir, preparar e assentar, e os substantivos casa e base, que fazem parte do vocabulário do momento vivido pelos que retornaram e reconstruíam o Templo, são, ao mesmo tempo, teologicamente coerentes e uma forma de ridicularizar aqueles que pensam em um culto alternativo fora de Jerusalém.

\section{e) A remoção e o significado da visão}

No entendimento de J. H. Gailey Jr. (1962), ${ }^{106}$ o sentido de Zc 5,5-11 é o de culto a deuses cananeus, e YHWH interveio de forma especial para remover a iniquidade da terra de Judá, assim como atuou no caso dos ladrões e perjuros de Zc 5,1-4.

Segundo J. G. Baldwin (1972), ${ }^{107}$ os que haviam retornado do exílio conviviam com diferentes padrões morais, e viver esse estilo de vida significava uma vida menos exigente do que a lei requeria. Para J. G. Baldwin, Zc 5,5-11 complementa Zc 5,1-4, o que mostra a preocupação do profeta Zacarias com o mal na sociedade e nas pessoas (cf. Zc 3,14). A remoção foi a resposta de YHWH, fiel à aliança (cf. S1 103,11-12). YHWH tem o mal sob controle e justifica o pecador. Este anúncio foi feito ao povo da aliança.

\footnotetext{
${ }^{106}$ Cf. J. H. GAILEY Jr., “Zechariah”, p.110-111.

${ }^{107}$ Cf. J. G. BALDWIN, Ageu, Zacarias e Malaquias, p.103-105.
} 
Segundo M. Delcor (1975), ${ }^{108}$ a remoção da deusa Astarte-Ishtar, aprisionada e enviada à Babilônia, lugar onde surgiu, mostra um paralelo da visão com o mundo hitita, em que aprisionavam não só mortais como demônios e até um deus, como foi o caso de Telepinu, provavelmente por influência indireta dos reinos canaanitas ou arameus.

Para W. Rudolph (1976), ${ }^{109}$ em oposição a São Jerônimo, para quem a remoção do efá para Senaar seria o fim da idolatria ("aeterna statione requiescat"), o estabelecimento de um culto pagão não significa o fim da idolatria, pois, a longo prazo, não poderia haver, ao lado de um governo divino em Sião, nenhum governo antidivino em Senaar, que acabaria por findar, mesmo com a adesão dos pagãos (cf. Zc 2,15).

A imagem extraordinária da visão não deve toldar o olhar para a ideia teológica nela contida. O pecado não é a soma de ações proibidas, mas o resultado de uma atitude fundamental do ser humano, pois não há um que não peque (cf. Gn $8,21 ; 1$ Rs 8,46$)$. O poder do pecado é tão grande, que é preciso a intervenção de YHWH, não para castigar, mas para mostrar sua misericórdia (cf. Ez 26,25-30). Enquanto houver seres humanos, haverá recaídas, fazendo com que a luta contra o pecado só termine quando YHWH afastar definitivamente o poder do pecado e instaurar seu reinado (cf. Is 11,9). A remoção em Zc 5,5-11 tem, portanto, o sentido de uma remoção preliminar visível, que deverá ter continuação no culto, a exemplo do grande dia da reconciliação (cf. Lv 16,21) e das cerimônias de purificação da lepra, em que um pássaro leva a impureza (cf. Lv 14,4-7.49-53).

C. Jeremias $(1977)^{110}$ compreende que o conteúdo e a mensagem de Zc 5,5-11 são a remoção da iniquidade. A remoção é expressão do zelo de YHWH por Jerusalém (cf. Zc 1,14), que provocará mudança fundamental na relação dos povos com YHWH (cf. Ez 36,25). Reestruturava-se a vida comunitária e o relacionamento do povo com YHWH.

No entendimento de Smith (1984), ${ }^{111}$ pela ação divina (cf. Zc 3, 9), a comunidade do pós-exílio expurgará os males sociais e a apostasia religiosa de Judá.

\footnotetext{
${ }^{108}$ Cf. M. DELCOR, "La vision de la femme dans l'épha de Zach", p. 137-145.

${ }^{109}$ Cf. W. RUDOLPH, Haggai - Sacharja 1-8 - Sacharja 9-14 - Maleachi, p. 118-121.

${ }^{110}$ Cf. C. JEREMIAS, Die Nachtgesichte des Sacharja, p. 194-200.

${ }^{111}$ Cf. R. L. SMITH, Micah-Malachi, p. 209-211.
} 
Segundo D. L. Petersen (1984), ${ }^{112}$ o efá e a mulher em seu interior representam a culpa e o pecado no cenário de restauração da comunidade pósexílica. Estas imagens presumem que o perpetrador desconhecido de Zc 5,1-4 fora identificado, as maldições funcionaram, o mal e a impureza foram recolhidos e devem ser removidos da terra. O efá será venerado pelos babilônios. O que foi roubado permitirá que a Babilônia se torne um lugar em que o mal e o erro serão instalados e venerados como em um culto. Zc 5,5-11 aborda a falta de justiça, explorada em Zc 1,7-17. A remoção da iniquidade estabelece o equilíbrio que se instalara com as pessoas retornando do exílio. Com isso, alcança-se o equilíbrio e a paz no mundo.

De acordo com P. C. Craigie (1985), ${ }^{113}$ o profeta Zacarias acreditava que ainda havia a relação de aliança entre YHWH e Israel e que, portanto, o culto ainda seria possível. A aliança continha bênçãos e maldições (cf. Zc 5,1-4) e, apesar da falta de ordem e justiça na sociedade, o crime não compensaria e o mal deveria ser removido completamente. Apesar do estado lastimável da sociedade, uma vida renovada para a nação seria possível. O profeta não enfatiza um programa de reforma social, talvez porque parecesse uma tarefa impossível. Mas há uma enorme confiança nas bênçãos de YHWH para a nação e a iniquidade não corromperia a sociedade. Zc 5,5-11 revela a preocupação divina com o estado moral da nação ao remover a iniquidade da terra como a única forma de lidar com o mal.

Para C. L. Meyers e E. M. Meyers (1987), ${ }^{114}$ era preciso remover o efá e a mulher em seu interior, para que houvesse o retorno de YHWH ao Templo em Jerusalém. A remoção traria equilíbrio e implicaria que deuses que invadiram Judá poderiam ser venerados, aparentemente de forma legítima, por seu povo e em seu próprio território. Admitindo-se que estes cultos pagãos fossem realmente importantes em Jerusalém, a remoção de imagens não javistas, que haviam sido introduzidas pelos dominadores em territórios conquistados como símbolo de poder, seria uma declaração de autonomia e semi-independência de Judá, com YHWH sozinho residindo na terra. A remoção seria, então, um apelo aos javistas e encorajamento para a restauração do Templo e reorganização da sociedade.

\footnotetext{
112 Cf. D. L. PETERSEN, Haggai and Zechariah 1-8, p. 254-263.

${ }^{113}$ Cf. P. C. CRAIGIE, “Zechariah”, p. 180-184.

${ }^{114}$ Cf. C. L. MEYERS; E. M. MEYERS, Haggai, Zechariah 1-8, p. 309-316.
} 
W. MacDonald (1989) entende que a remoção da mulher e do efá, símbolos de religiões idólatras e mercenárias, para o antigo lar na Babilônia, representava uma etapa preparatória para o julgamento da Babilônia e estabelecimento do reino de YHWH. Com a remoção, Israel foi purificado da idolatria após o exílio na Babilônia.

M. M. Pazdan (1989) ${ }^{115}$ lembra que, da mesma forma que YHWH remove as vestes sujas de Josué (cf. Zc 3,3), agentes divinos irão remover a iniquidade em toda a terra (da comunidade), de forma que não haja contaminação do mal. O efá e a mulher estavam fora do padrão de reorganização da comunidade, e uma remoção era necessária para a restauração das relações de aliança com YHWH e de suas obrigações (cf. Zc 5,1-4).

Segundo T. McComiskey (1992), ${ }^{116}$ a remoção da iniquidade era necessária e Zc 5,1-4 tratava apenas da desobediência à lei. Em Zc 5,5-11 é feita a remoção absoluta do pecado e YHWH escreverá sua lei no coração do povo e não mais se lembrará de suas transgressões (cf. Jr 31,31-34). Embora o povo não tivesse consciência de toda a extensão do sentido da visão, sabia, de certa forma, que YHWH havia removido a iniquidade que o levou ao exílio. Se houvesse apenas uma perspectiva futura, a visão não faria sentido para os reconstrutores do Templo. Incentivados pela confiança na ajuda divina, trabalhavam sabendo que os pecados do passado não atrapalhariam os esforços do presente.

De acordo com Ben C. Ollenburger (1996), ${ }^{117}$ o efá representa o efeito residual da dominação que permaneceu como uma longa história de opressão e ocupação (cf. Zc 2,1-4). O efá possui conotação religiosa e econômica. Com a remoção do efá, se recupera e se faz a revisão da identidade do povo de Judá. Zacarias empenha-se em definir o povo de Judá como povo de YHWH na Terra santa. Definição inclui limites, e identificação envolve formação de fronteiras religiosas que são determinadas pela presença de YHWH para uma comunidade fiel (cf. Zc 2,16). Para estabelecer os limites reivindica-se fidelidade (inclusão) e são removidas a corrupção, a opressão e a injustiça, representadas pelo efá e estranhas à identidade do povo de Israel (exclusão).

\footnotetext{
${ }^{115}$ Cf. M. M. PAZDAN, "Zacarias”, p. 155-167.

${ }^{116}$ Cf. T. E. McCOMISKEY, "Zechariah”, p. 1099-1104.

${ }^{117}$ Cf. B. C. OLLENBURGER, The Book of Zechariah, p. 776-781.
} 
M. H. Floyd (1996), ${ }^{118}$ que faz a leitura de Zc 5,5-11 à luz de Zc 4,1-14 (candelabro) e Zc 5,1-4 (rolo), acredita que a visão em foco parece caricaturar uma alternativa de vida comunitária fora de Jerusalém. Nesse sentido, a remoção do efá para Senaar não significaria que YHWH estaria eliminando a iniquidade de Judá. Um culto judaico, com uma imagem antropomórfica de uma deusa e fora de Jerusalém, é teologicamente objetável porque não pode fornecer a base da identidade judaica.

G. Emmerson (1998) ${ }^{119}$ entende que a remoção simboliza o extermínio do mal da comunidade, uma ação simbólica que pode ter origem no antigo ritual israelita do bode expiatório no Dia do Perdão (cf. Lv 16,21-22). A remoção seria uma ruptura com o passado, um novo nascimento.

R. Hanhart (1998) ${ }^{120}$ acredita que a remoção do efá para a terra de Senaar é o afastamento da culpa no âmbito sagrado de YHWH. Dessa maneira, o desfecho da visão está formalmente relacionado com Zc 5,1-4, o rolo que voa introduzido com a mesma fórmula de Zc 5,5-11, e o mesmo juízo. De início, o juízo se realiza na destruição da casa dos transgressores da lei, para, a seguir, vir sobre a casa dos que estão além da lei, os iníquos em Senaar.

No entendimento de J. Schnocks (2008), ${ }^{121}$ toda a iniquidade que pode ser encontrada na terra é exilada para que possa haver um recomeço. A remoção é resultado das promessas divinas (cf. Zc 3,9) cumpridas em Zc 5,5-11, representando a ação de YHWH e o resultado de sua misericórdia para Judá e Jerusalém.

H. Delkurt $(2008)^{122}$ lembra que os pecados que levaram ao exílio na Babilônia ainda não foram expiados. As transgressões não chegaram ao fim, e roubo e perjúrio estavam ainda entre as causas mais importantes para o julgamento de YHWH. A expiação não virá em um único ato. Estes pecados deviam ser removidos antes que a salvação começasse. Como o povo de Israel se mostrava incapaz de remover seus pecados, o próprio YHWH vai eliminá-los, punindo (cf. Zc 5,1-4) e removendo. YHWH punirá os culpados e removerá o pecado, depositando-o em uma área mítica, abolindo-o, não só de Israel como de

\footnotetext{
${ }_{118}$ Cf. M. H. FLOYD, "The Evil in the Ephah", p. 51-68.

${ }^{119}$ Cf. G. EMMERSON, Prophets II, p. 104-105.

${ }^{120}$ Cf. R. HANHART, “Dodekapropheton 7.1, Sacharja 1-8”, p. 19.

${ }^{121}$ Cf. J. SCHNOCKS, “An Ephah between Earth and Heaven”, p. 252-270.

${ }^{122}$ Cf. H. DELKURT, "Sin and Atonement in Zechariah's Night Visions", p. 235-251.
} 
toda a terra. Zacarias retoma um tema clássico da área do perdão dos pecados e apresenta-o de uma nova maneira.

De acordo com M. Butterworth (2009), ${ }^{123}$ a remoção da iniquidade, que não encontra lugar no meio do povo, é a purificação feita por obra do Espírito de YHWH.

Para M. Hallaschka (2010), ${ }^{124}$ a remoção tem por objetivo criar novas relações fundamentais na terra, e equivale a um rito de eliminação como nos cultos de expiação de Israel. A terra de Judá e seus habitantes serão purificados. Zc 5,1-4 é claramente superada, com seus casos individuais transformados em iniquidade em Zc 5,5-11.

E. Assis (2010), ${ }^{125}$ que interpreta a mulher no efá como representação dos samaritanos, considerados adversários dos judeus no pós-exílio, compreende que a remoção seria o retorno desse povo à sua origem, a Babilônia.

Segundo A. E. Hill (2012), ${ }^{126}$ a remoção da mulher, representando o pecado da idolatria, seria uma ironia, pois o efá (santuário) e a mulher (deusa) estariam retornando ao lugar de onde haviam saído, talvez para executar uma tarefa de destruição em sua origem. O efá é a capa visível do julgamento e perdão de YHWH para Israel, que só se completará dando-se seguimento à restauração. Assim, YHWH remove a idolatria da Terra Prometida (cf. Lv 18,24-25), enviando-a de volta à Babilônia.

D. Rudman (2015), ${ }^{127}$ que faz um paralelo entre Zc 5,5-11 e textos sacerdotais, acredita que a purificação da comunidade acontece em duas etapas: aquilo que está doente deve ser destruído e os escombros devem ser removidos para fora da terra, para um lugar impuro, assim como o sacerdote remove da comunidade os escombros para purificar a área ocupada pela casa (cf. Lv 14, 33 $54)$.

De acordo com M. Seufert (2015), ${ }^{128}$ a mulher no efá é a esposa infiel de Jeremias (cf. Jr 23,10), identificada como iniquidade, representando os saques de territórios conquistados pelos babilônios, e, removida, se transformaria em peça

\footnotetext{
${ }^{123}$ Cf. M. BUTTERWORTH, “Zacarias”, p. 1308-1309.

${ }^{124}$ Cf. M. HALLASCHKA, Haggai und Sacharja 1-8, p. 242-250.

${ }^{125}$ Cf. E. ASSIS, “Zechariah's Vision of the Ephah (Zech. 5:5-11)”, p. 15-32.

${ }^{126}$ Cf. A. E. HILL, "Zechariah”, p. 166-170.

${ }^{127}$ Cf. D. RUDMAN, "Zechariah 5 and the Priestly Law”, p. 194-206.

${ }^{128}$ Cf. M. SEUFERT, “Zechariah 5:5-11: Why an ephah?”, p. 289-296.
} 
de museu em Senaar. A não destruição seria uma alternativa melhor, mas não necessariamente positiva.

Para M. J. Boda (2016), ${ }^{129}$ como YHWH dissera que ficaria afastado do santuário por causa das abominações (cf. Ez 8,6), a idolatria precisava ser removida para que Ele voltasse ao Templo em reconstrução. YHWH abandonara Jerusalém por causa da desobediência do povo (cf. Ez 10,1-22), e em Zc 5,5-11 a causa desse abandono anterior está sendo removida.

\section{Sintese}

Certamente, para os estudiosos que atribuem a Zc 5,5-11 o sentido de idolatria, a remoção visa a banir o culto pagão da comunidade (C. L. Meyers e E. M. Meyers, T. McComiskey, C. Uehlinger, J. Schnocks, J. G. Baldwin, W. Rudolph, C. Jeremias, D. L. Petersen, M. M. Pazdan, M. Butterworth, M. J. Boda, J. H. Jr. Gailey, M. Delcor, R. Mason, R. L. Smith, W. MacDonald, G. Emmerson, M. Hallaschka, A. E. Hill, Ben C. Ollenburger, M. Seufert, D. Rudman).

Alguns lembram que a remoção acontece por intervenção divina (J. H. Jr. Gailey, J. G. Baldwin, R. L. Smith, P. C. Craigie, M. M. Pazdan, T. McComiskey, J. Schnocks, H. Delkurt, M. Butterworth e A. E. Hill), outros procuram um objetivo mais específico para a remoção: a) equilibrar Judá e declarar sua autonomia e semi-independência com YHWH sozinho no Templo, e encorajar os javistas (C. L. Meyers e E. M. Meyers); b) julgar a Babilônia e estabelecer o reino de YHWH (W. MacDonald); c) recuperar e revisar a identidade do povo de YHWH (Ben C. Ollenburger); d) satirizar grupos interessados em cultos alternativos fora de Jerusalém (M. H. Floyd); e) representar ação semelhante ao rito de eliminação do bode expiatório (G. Emmerson, M. Hallaschka) ou da remoção dos escombros (D. Rudman); f) afastar a culpa do espaço sagrado de YHWH (R. Hanhart); g) eliminar o conflito com os samaritanos (E. Assis); h) colocar a infidelidade a YHWH como peça de museu na Babilônia, ao lado dos objetos saqueados do Templo (M. Seufert); i) afastar abominações que impeçam a

\footnotetext{
${ }^{129}$ Cf. M. J. BODA, The Book of Zechariah, p. 340-355.
} 
presença de YHWH no Templo de Jerusalém; j) libertar, preliminarmente, o povo do pecado, o que deve continuar no culto.

\section{3.}

\section{Nova proposta de interpretação para Zc 5,5-11}

Nas últimas décadas, as interpretações de Zc 5,5-11 seguem a leitura da LXX ou os estudos de Marenof (1932). Os que seguem a LXX entendem que o "olho deles em toda terra" (v.6f) seria a "iniquidade deles em toda a terra". Os que seguem Marenof entendem que o efá representa um zigurate, e o olho deles em toda a terra seria a visibilidade do efá. Por vezes, os estudiosos juntam a LXX e Marenof em suas interpretações. Ambos os grupos consideram o efá um templo (v.6d), e uma mulher sentada em seu interior uma deusa de culto pagão (v.7b) e símbolo da iniquidade (v.8b), com pouquíssimas e pequenas variações.

Esta linha de interpretação acarreta alguns problemas. Primeiro, a mulher recebe dois atributos, um relativo ao "olho deles" (v.6f) e outro relativo à "iniquidade" (v.8b) e, em consequência, é qualificada de forma pejorativa, como libidinosa, sedutora, aquela que conduz o homem ao pecado, etc. Nada há no texto que justifique essa interpretação.

Segundo, ao centrar todo o sentido da visão na figura da mulher, deixa-se de analisar devidamente os demais elementos em seu contexto sócio-religioso. O efá, por exemplo, tradicionalmente denunciado por profetas como símbolo de injustiça social, passa a fazer parte do significado da mulher. Outros elementos (disco, pedra e chumbo), que parecem não se encaixar no cenário de culto pagão, são ignorados, ficando sem significado na experiência visionária.

O terceiro problema ocorre com a remoção, sem morte ou destruição. A interpretação da visão como idolatria não explica a remoção da mulher para Senaar (terra de origem do culto pagão) e os cuidados em construir uma casa e prepará-la para assentar uma deusa, sobre sua base. A remoção, em vez de punição, se parece com um beneplácito divino.

Constatando-se que há problemas na interpretação de Zc 5,5-11, este trabalho é apresentado como contribuição ao entendimento da visão. Para isso, cada elemento é valorado e reconhecido seu significado dentro do contexto social 
e religioso do século VI a.C., quando a comunidade reconstruía o Templo e se reorganizava sob nova forma, apesar de subjugada pelos persas.

O efá (v.6d), enquanto medida de alimentos, justa ou injusta, representa o elemento de vida e morte para o povo, em sua maioria necessitado. O efá é conhecido dentro da tradição profética como um símbolo de injustiça social cometida por aqueles que têm poder e exploram os irmãos da comunidade.

O olho deles em toda a terra (v.6f) simboliza a rede de vigias do Império Persa, funcionários oficiais e não oficiais (podendo ser o próprio irmão da comunidade em busca de poder e vantagens) encarregados de espionar os súditos para informar acerca da arrecadação dos tributos e da lealdade com o rei.

Os elementos que servem de "tampa" para o efá e que o acompanham em seu destino final, disco, pedra e chumbo (vv.7a.8d), simbolizam também a injustiça social em transações comerciais e a exploração de irmãos na comunidade. Com estes elementos se aprisiona a mulher no efá para removê-la para Senaar.

A mulher no efá, o elemento enigmático da visão, é, literalmente, "uma mulher" (v.7b). Certamente, um problema nas relações inter-humanas da comunidade, da mesma forma que o "efá" e o "olho deles". A novidade deste trabalho está na consideração de que a mulher não simbolizava "o mal" da comunidade, mas "um comportamento" que prejudicava o projeto de organização social da comunidade do retorno na nova era, no entendimento dos líderes religiosos.

Os fundamentos para esse entendimento se encontram nas narrativas bíblicas da Sagrada Escritura, principalmente as que abordam ações e questões femininas, e nos dados históricos e arqueológicos, sabendo-se que as informações do período persa não são extensas. Somente com o conhecimento de conteúdos que mostrem o comportamento da mulher se poderá compreender o sentido de "uma mulher" precisar ser contida dentro de um efá e levada para fora de Judá.

O aprisionamento e a remoção da mulher mostram que seu comportamento no retorno do exílio desagradou aos líderes religiosos da comunidade. Essa mulher tanto pode ser a judia, solteira, casada ou viúva, como a esposa estrangeira, tanto a que retornou do exílio como a que permaneceu na terra. Todas, de certa forma, exercendo influência sobre os homens através de seu relacionamento como mãe, filha, esposa, irmã. 
Se a mulher no efá incomodava a ponto de ser aprisionada e removida, deve-se perguntar o porquê do cuidado especial com seu exílio. Zc 5,5-11 apresenta ideias antagônicas de exclusão e acolhimento, a exclusão atendendo aos ideais proféticos de fidelidade a YHWH e às tradições, e o acolhimento mostrando a misericórdia divina. Tudo evidencia uma mudança na orientação teológica do pós-exílio. Os elementos da visão enfatizam o contexto de mudança:

a) mulheres com asas de cegonha (animal impuro) enfatizam o trabalho da mulher na tarefa divina, ignorando a impureza da cegonha e lembrando que a impureza, embora possa contaminar o outro, pode ser removida sem que adira à pessoa (cf. Lv 19,6; Nm 5,15);

b) terra de Senaar, um lugar próximo, acena com a possibilidade de o transgressor poder voltar a qualquer momento, pois toda a terra repousa e está tranquila (cf. Zc 1,11), aguardando o convite dos habitantes das cidades que irão rogar e buscar YHWH (Zc 8,21);

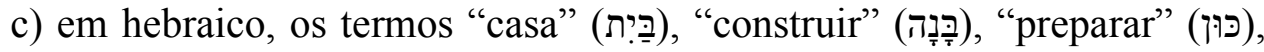

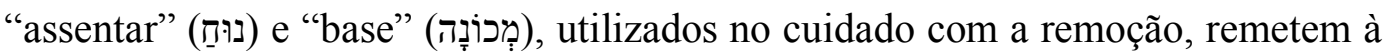
ideia de proteção e formação familiar (vv.11bd);

Na remoção, acompanhada de zelo, está embutida a ideia de um retorno de todos os transgressores, inclusive os iníquos. A iniquidade (v.8b) simboliza as transgressões pequenas e grandes, leves e graves, conscientes e inconscientes. YHWH, que estava permitindo o retorno do exílio, a reconstrução do Templo e a organização da comunidade sob um reinado duplo, civil e religioso (cf. Zc 4,115), agora afastava os transgressores do seu relacionamento, que convertidos poderiam voltar para restabelecer uma vida de justiça e de paz social (cf. Is 6,7; Zc 3,4).

O retorno do exílio foi difícil, não só pelo próprio retornar, que exigia coragem, determinação e esperança, como pelas dificuldades encontradas de miséria e insegurança, fazendo-se necessário reconstruir o Templo e a cidade e reorganizar a comunidade. O momento exigia controle dos escassos recursos humanos. Os novos tempos requeriam a força e o trabalho de cada pessoa, homem e mulher, para a realização das promessas divinas (cf. Zc 2,10-11; 6,15). A perspectiva era de que a mulher aparecesse como ser complementar ao homem (cf. Gn 1,26). 


\section{3}

\section{O livro do profeta Zacarias}

\section{1.}

\section{Origem e redação}

O livro do profeta Zacarias faz parte da coleção dos Doze, conhecida também por Profetas Menores na BH (cf. Eclo 49,12) e por Flávio Josefo. ${ }^{130}$ Segundo a tradição judaica, que se baseou na abordagem interpretativa conhecida como midrash halakhah, a coleção foi organizada para contar um episódio sobre a história de Israel. De acordo com antigas tradições manuscritas, hebraicas e gregas, a maioria dos livros desta coleção, se não todos, foram escritos em um único pergaminho. Contudo, a prática dos escribas não indica, explicitamente, que se trate de uma unidade literária. ${ }^{131}$

A ordem dos Doze Profetas varia segundo os cânones da BH, Qumran e LXX, contudo, em várias destas listas, a sequência final, com os livros de Naum a Malaquias, parece bastante estável. O livro de Zacarias aparece entre os livros dos profetas Ageu e Malaquias, sendo os três considerados uma subcoleção distinta ou um corpus literário dentro do livro dos Doze. Estes três livros, no contexto do período persa, sugerem ter sido unificados por um artifício literário como, por exemplo, uma pergunta retórica e temas teológicos que pudessem conduzir à adoração adequada de YHWH e à prática da justiça social. ${ }^{132}$

Entretanto, em vez de uma unidade ampla, movimentos interpretativos relacionados ao livro de Zacarias terminaram por dividi-lo em duas partes. Primeiro, São Jerônimo ${ }^{133}$, e, em seguida, Robert Lowth ${ }^{134}$ consideraram o livro de Zacarias um texto literário obscuro. Predominou a ideia de que o livro dependia de outros livros proféticos como, por exemplo, de Is 10,5-12,6. As

\footnotetext{
${ }^{130}$ Cf. F. JOSEPHUS, The New Complete Works of Josephus. Grand Rapids: Kregel, 1999, p. 336-337.

${ }^{131}$ Cf. M. L. C. LIMA, “Doze profetas ou Livro dos Doze?”. In: ATeo 11 (2007), p. 194-216; A. E. HILL, "Zechariah", p. 35.

${ }^{132}$ Cf. A. E. HILL, “Zechariah”, p. 35-36.103-118.

${ }^{133}$ Cf. Citado por P. LAMARCHE, Zacharie IX-XIV. Structure littéraire et messianisme. Paris: Gabalda et Cie, 1961, p. 7.

${ }^{134}$ Cf. R. LOWTH, Lectures on the Sacred Poetry of the Hebrews. London: TEGG \& Co. Dublin; Griffin \& Co. Glasgow; Sydney: James and Samuel Augustus TEGG, 1839, p. 235.
} 
dificuldades com o texto, a autoria e a relação terminológica com outros livros fizeram com que o livro do profeta Zacarias não despertasse muito interesse nos estudiosos. Assim, as afirmações de São Jerônimo continuaram a ressoar no tempo até o século XVII, quando um grupo de teólogos cristãos, na tentativa de refutar a vinculação de Zc 11,13 com o profeta Jeremias (Mt 27,9), identificaram distinções literárias entre as duas partes. Isto fez com que, no século XVIII, o livro fosse separado em dois blocos, Zc 1-8 e Zc 9-14, designados, respectivamente, Proto e Dêutero Zacarias. ${ }^{135}$

Desde então, os estudos continuaram e as pesquisas foram aprofundadas a ponto de se considerar a hipótese de um Trito Zacarias, formado pelos capítulos 12-14. A leitura atual mantém os dois blocos, Zc 1-8 e Zc 9-14, justificando a separação sob o seguinte argumento: ${ }^{136}$

a) em Zc 1-8, o nome Zacarias aparece três vezes (cf. Zc 1,1.7; 7,1); em Zc 9-14, não há nenhuma referência ao profeta;

b) Zc 1-8 possui três fórmulas de datação; em Zc 9-14 não há datas ou eventos como, por exemplo, a conclusão do Templo, (que foi absolutamente ignorada);

c) gêneros diferentes, Zc 1-8 possui visões e oráculos; Zc 9-14 possui poesia profética;

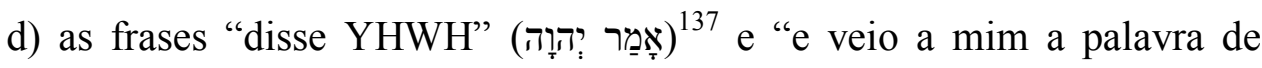

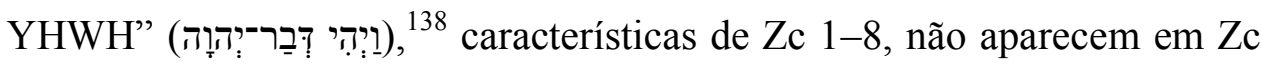

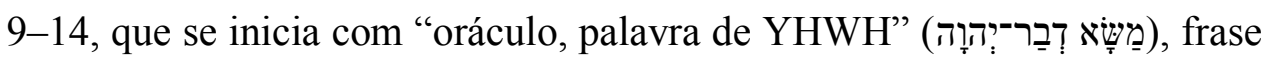
que não consta em $\mathrm{Zc} 1-8$.

Zc 9-14 continua obscuro com a ausência de menção ao nome de um profeta e de qualquer referência ao Templo, o que torna difícil localizá-lo na história. ${ }^{139}$ Assim, considera-se até que Zc 9-14 sequer deva ser atribuído ao

\footnotetext{
${ }^{135}$ Cf. M. J. BODA, "From Fast to Feasts: The Literary Function of Zechariah 7-8". In: CBQ 65 (2003), p. 390-407; J. C. PAKALA, "Short Contribution, A Librarian's Comments on Commentaries 31". Presbterion, 37/1 (2011), p. 49-53; F. P. M. ALMEIDA, "Zacarias o livro pela pesquisa". In: REET 3 (2008), <https://revistas.pucsp.br/reveleteo/article/view/6763/4893>. Acesso: 13 abr. 2019.

${ }^{136}$ Cf. J. G. BALDWIN, Ageu, Zacarias e Malaquias, p. 47-48.

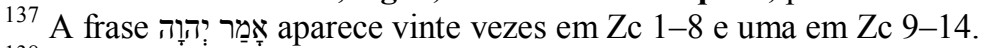

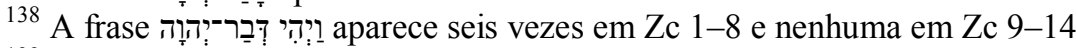

139 Cf. J. G. BALDWIN, Ageu, Zacarias e Malaquias, p. 47. Para M. M. PAZDAN (cf. "Zacarias", p. 155-156) Zc 1-8 e Zc 9-14 estão separados por dois séculos de história política e religiosa.
} 
profeta Zacarias, ${ }^{140}$ e que deve ter sido um escrito anônimo, de natureza profética, que para não se perder, foi anexado ao rolo, logo após Zc $1-8 .{ }^{141} \mathrm{O}$ debate sobre o assunto parece ainda estar em aberto, tanto que, recentemente, houve maior receptividade em considerar Zc 1-14 uma unidade. O que se observa na prática, no entanto, é o estudo separado de Zc $1-8$ e de Zc 9-14. ${ }^{142}$

A separação em duas unidades abriu-se à hipótese de os livros de Ageu e Zc 1-8 formarem um trabalho composto. De fato, os dois livros parecem mostrar a mesma preocupação com a reconstrução do Templo, vista como o momento decisivo para a inauguração da nova era da salvação. ${ }^{143}$

Ageu se concentra na reconstrução do Templo e conclama o povo a mudar o comportamento em relação à reconstrução, enquanto Zacarias amplia esta mensagem conclamando o povo a mudar o comportamento ético. Zc 1,1-6 parece desempenhar papel de ligação entre o final de Ageu (cf. Ag 2,10-13) e Zc 1-8. A fórmula de datação conecta os dois livros e indica a data em Zc 1,1 como anterior a Ag 2,10-23. Observa-se, assim, que a conclamação de Zacarias a uma penitência ética (cf. Zc 1,1-6) ocorreu antes das promessas de Ageu, na época da construção do Templo (cf. Ag 2,10.20). ${ }^{144}$

Assim, são apontadas como evidências que comprovam que o livro de Zc 1-8 está estreitamente relacionado com o livro de Ageu:

a) a semelhança na edição dos livros; ${ }^{145}$

b) o contexto comum do retorno do exílio na Babilônia;

c) a atividade profética no mesmo período, às vezes coincidindo no tempo;

d) a mesma temática em torno da reconstrução do Templo, Ageu incentivando a conclusão dos trabalhos, e Zacarias despertando a consciência do povo para o significado do culto e de uma vida justa e fiel;

e) os mesmos personagens e problemas apresentados;

f) a estrutura literária com características comuns. ${ }^{146}$

\footnotetext{
${ }^{140}$ Cf. P. R. ACKROYD, "The book of Haggai and Zechariah I-VIII". In: JJS 3 (1952), p. 151156.

${ }^{141}$ Cf. J. G. BALDWIN, Ageu, Zacarias e Malaquias, p. 47-48.

${ }^{142}$ Cf. M. M. PAZDAN, "Zacarias”, p. 155-156.

143 Cf. P. R., ACKROYD, "The book of Haggai and Zechariah I-VIII", p. 155-156. In: R. MASON, The book of Haggai, Zechariah and Malachi, p. 56-58; M. J. BODA, The Book of Zechariah, p. 62; C. L. MEYERS; E. M. MEYERS, Haggai, Zechariah 1-8, p. xliv-xlvii.

${ }^{144}$ Para M. J. BODA (The Book of Zechariah, p. 62) Zacarias lembra, de forma sutil, que o arrependimento/penitência era tão importante quanto a reconstrução do templo, como sinal de obediência a YHWH.

${ }^{145}$ Cf. R. MASON, The book of Haggai: Zechariah and Malachi, p. 56-58.
} 
Este trabalho acompanha o julgamento crítico de estudiosos que consideram Zc 1-8 uma unidade. ${ }^{147}$ As fórmulas de datação do livro (cf. Zc 1,1.7; 7,1) indicam claramente a identidade do profeta, que escreve para os que retornaram e para os que ainda permanecem no exílio. O nome "Zacarias" (זְְרִיָה), considerado um nome comum no contexto do Antigo Testamento, aparece vinte e cinco vezes, e significa "o Senhor se lembrou". ${ }^{148}$

Duas fórmulas na $\mathrm{BH}$ mencionam que Zacarias era "fillho de Baraquias, filho de Ado" (cf. Zc 1,1.7), e a terceira (cf. Zc 7,1) omite a expressão integralmente. A expressão "filho de Ado" possui o sentido de "neto de Ado", um uso comum no AT, designando simplesmente "filho" com o sentido de "descendente", a exemplo da utilização no livro de Esdras, que indica a ascendência do profeta simplesmente como "filho de Ado", omitindo uma geração (cf. Esd 5,1;6,14). ${ }^{149}$

Informações a respeito de figuras nomeadas como Zacarias e Ado podem ser obtidas no livro de Neemias, que menciona certo Ado como integrante do grupo de sacerdotes e levitas que retornaram de Jerusalém com Zorobabel e Josué (cf. Ne 12,4), e um certo Zacarias como da família sacerdotal de Ado (cf. Ne 12,16), sem fazer qualquer referência a Baraquias, o pai do profeta. A não menção a Baraquias em Esdras, ou Neemias, fez com que se pensasse que o nome Baraquias teria sido incorporado a $\mathrm{Zc} 1,1 \mathrm{com}$ base em Is 8,2, que menciona um Zacarias, filho de Baraquias, um contemporâneo de Isaías. ${ }^{150}$

A dificuldade em discernir quem seria Ado, mencionado em Zc 1,1 e Zc 1,7, fez com que a expressão "filho de Ado" fosse considerada glosa (cf. Zc 1,1). A ênfase dada à genealogia, nas três fórmulas, sugere que dois aspectos foram enfatizados intencionalmente nas fórmulas de introdução (cf. Zc 1,1.7; 7,1) e com um objetivo determinado. O primeiro seria colocar o nome "Zacarias", que por ser um nome conservador, provavelmente provocaria sensação de continuidade com a

\footnotetext{
${ }^{146}$ Cf. C. L. MEYERS; E. M. MEYERS, Haggai, Zechariah 1-8, p. xliv-xlvii; P. R. ACKROYD, "The book of Haggai and Zechariah I-VIII", p. 151-156.

${ }^{147}$ Cf. D. L. PETERSEN, Haggai and Zechariah 1-8, p. 110-125; M. BUTTERWORTH, "Zacarias", p. 1308-1309.

${ }^{148}$ O nome "Zacarias" ocorre três vezes no livro de Reis (cf. 2Rs 14,29; 15,11; 18,2), sete vezes no livro de Crônicas (cf. $1 \mathrm{Cr} 9,21.37 ; 15,20 ; 16,5 ; 2 \mathrm{Cr} 17,7 ; 24,20 ; 34,2$ ), quatro vezes em Ezequiel (cf. Ez 8,3.11.16; 10,26), sete vezes em Neemias (cf. Ne 8,4;11,4.5.12; 12,16.35) e quatro vezes no livro de Zacarias (cf. Zc 1,1.7; 7,1.8).

${ }^{149}$ Cf. A. E. HILL, "Zechariah", p. 103-118.

${ }^{150}$ Cf. R. MASON, The book of Haggai: Zechariah and Malachi, p. 56-58.
} 
tradição judaica, pois o sentido do nome sugere que YHWH se lembra do que fez com e por Israel, no passado, presumindo que fará de novo, de maneira semelhante. O segundo seria, com a genealogia, pelo menos apontar para uma conexão entre os que viveram no exílio e os que agora precisam reconstruir o Templo e a sociedade. ${ }^{151}$

Assim, esperava-se que a genealogia ressaltasse a importância da atividade sacerdotal no momento em que se reorganizava a sociedade, depois que o sacerdócio foi extirpado no exílio. Ao enfatizar a genealogia do profeta, o editor mostrou "preocupação estritamente profissional, sacerdotal". ${ }^{152}$ Foi preciso restaurar o sacerdócio após o exílio, e alguns membros da linhagem sacerdotal podiam estar mais preocupados do que Zacarias com a questão.

Dois grupos sacerdotais disputavam posição, os assimilacionistas, que conviviam harmoniosamente com os vizinhos e imigrantes, até contraindo núpcias com estrangeiros, e os javistas, empenhados em separação social e religiosa. Embora seja um texto complexo, Zc 7,1-3 pode conter indício dessa tensão, pois não há testemunho da restauração do santuário de Betel após a reforma de Josias e de sua atividade durante o exílio. ${ }^{153}$

Embora Zacarias tivesse preocupações com a restauração do Templo (cf. Zc 1,16; 4,9; 6,13.15), do culto (cf. Zc 4,2) e do sacerdócio (cf. Zc 3,6.7; 6,14), ele parece sugerir uma restauração alternativa, ou pelo menos uma revisão das noções de restauração dessas realidades. ${ }^{154}$

Nesse sentido, a comparação das profecias de Zacarias com as de Ezequiel (cf. Ez 40-48) enfatiza o caráter alternativo nas profecias do primeiro, por exemplo, diante da amplidão das divergências sobre temas comuns, conforme mostrado abaixo: ${ }^{155}$

a) em Ezequiel, a atividade de restauração de YHWH acontece "na terra de Israel" (cf. Ez 40,1-2); em Zacarias, ela é de âmbito cósmico (cf. Zc 1,11; $3,9) ;^{156}$

\footnotetext{
${ }^{151}$ Cf. D. L. PETERSEN, Haggai and Zechariah 1-8, p. 110-125.

${ }^{152} \mathrm{Cf}$. M. DOUGLAS, As lágrimas de Jacó, o trabalho sacerdotal de reconciliação. São Paulo: Loyola, 2004, p. 19.29.

${ }^{153}$ Cf. R. De VAUX, Instituições de Israel no Antigo Testamento. São Paulo: Vida Nova, 2004, p. $385-435$.

${ }^{154}$ Cf. D. L. PETERSEN, Haggai and Zechariah 1-8, p. 110-125.

${ }^{155}$ Cf. D. L. PETERSEN, Haggai and Zechariah 1-8, p. 110-125.

${ }^{156}$ Cf. também Zc 4,10.14; 5,3.6.9; 6,5; 7,5).
} 
b) em Ezequiel, um Templo deve ser construído para iniciar a nova ordem (cf. Ez 40,48-41,26); em Zacarias, os seres humanos devem aguardar que a divindade e seus agentes operem (cf. Zc 5,1-4; 5,5-11);

c) em Ezequiel, a nova Jerusalém tem formato determinado (cf. Ez 48,3035); em Zacarias, a cidade não terá muros e será densamente povoada (cf. Zc 2,1-4);

d) em Ezequiel, YHWH estará presente na cidade restaurada (cf. Ez 43,19); em Zacarias, YHWH não ficará limitado ao Templo, pois ele mesmo será um muro de fogo e a glória no meio da cidade (cf. Zc 2,5-9);

e) em Ezequiel, o sacerdócio deve ser restaurado e os saduceus fornecerão o núcleo de liderança sacerdotal, havia sacerdotes que não tinham se tornado suspeitos (cf. Ez 45,10-31); Zacarias não menciona nenhum grupo, nem degradados nem não degradados; para ele, o sacerdócio deve começar com Josué, que para isso deve ser purificado (cf. Zc 3,1-7);

f) em Ezequiel, a ordenação se assemelha a uma atividade colegial, sem hierarquia (cf. Ez 44,15-31); Zacarias reconhece grupos sacerdotais (cf. Zc 3,8 ), mas elege um sumo sacerdote com prerrogativas (cf. Zc 3,7);

g) Ezequiel não esperava uma restauração monárquica e a redefine de acordo com sua função de servo de YHWH, dedicado à liturgia (cf. Ez 45,13-46,15); Zacarias vê duas oliveiras, os dois ungidos, Josué e Zorobabel, na política diárquica (cf. Zc 6,9-15);

h) Ezequiel acredita que a comunidade pós-exílica se manterá sem desordem, na expectativa da realização de novas alianças (cf. Ez 43,7); Zacarias parece mais pragmático e vê uma sociedade não tão perfeita, vivendo nova ordem que inclui os que violaram a aliança e ainda permanecem impunes (cf. Zc 5,1-4).

Assim, é possível que Zacarias, embora com pensamento diferente do grupo sacerdotal, fosse mesmo neto de Ado, conforme o demonstra uma lista da época do movimento de restauração do Templo, em que o avô consta do registro de sacerdotes (cf. Ne 12,1-7) e levitas (cf. Ne 12,8-9) que acompanharam Josué e Zorobabel no retorno a Jerusalém (cf. Ne 12,4). É possível até que fosse relevante para o editor, que colocou as fórmulas de datação, enfatizar a função sacerdotal para contemporizar as ideias inovadoras do profeta. 
O sumo sacerdócio era uma função herdada e nos registros dos que serviram nessa função, entre 538 e 300 a.C., constam Josué, que participou da etapa inicial da restauração, logo depois de 538 a.C., e seu neto Eliasib, um contemporâneo de Neemias e sumo sacerdote, de 445 a 433 a.C. (cf. Ne 3,1.20.21). Em outra lista, de sacerdotes e levitas, consta Joaquim, aparentemente um sumo sacerdote da época posterior à dedicação do Templo, portanto, entre 515 e 445 a.C., tempo em que Zacarias aparece como chefe da família sacerdotal de Ado (cf. Ne 12,16). Com isso, pode-se deduzir que Zacarias teria sido sim, chefe de família sacerdotal entre 500 e 460 a.C.

As fórmulas ao longo do livro (cf. Zc 1,1.7; 7,1), além de indicar Zacarias como aquele que recebeu a palavra de $\mathrm{YHWH}$, indicam também três datas distintas para três revelações divinas ao profeta. As datas são originalmente mencionadas de acordo com o antigo calendário lunar judaico que considera cada mês iniciando na lua nova, havendo necessidade, portanto, de encontrar o equivalente moderno para cada data informada nas fórmulas. Para isso, é preciso sincronizar o antigo calendário lunar com o calendário Juliano, com auxílio de evidências de textos babilônicos, e de tabelas da lua nova calculadas com informações astronômicas. ${ }^{157} \mathrm{O}$ resultado obtido com a sincronização apresenta pequena margem de erro de um dia, conforme se pode constatar pela tabela abaixo: ${ }^{158}$

$\begin{array}{lcccccc} & \begin{array}{c}\text { ano de } \\ \text { Dario }\end{array} & \text { mês } & \begin{array}{c}\text { mês } \\ \text { babilonico }\end{array} & \begin{array}{c}\text { data da } \\ \text { lua nova }\end{array} & \text { dia } & \begin{array}{c}\text { data equivalente no } \\ \text { calendário Juliano (a.C.) }\end{array} \\ \text { Zc } 1,1 & 2^{\text {o }} & 8^{\text {o }} & \text { reshvan } & 27 \text { out } & - & \text { nov/dez } 520^{159} \\ \text { Zc } 1,7 & 2^{\text {o }} & 11^{\text {o }} & \text { shevat } & 23 \mathrm{jan} & 24^{\circ} & 15 \mathrm{fev} 519 \\ \mathrm{Zc} 7,1 & 4^{\mathrm{o}} & 9^{\mathrm{o}} & \text { kislev } & 4 \mathrm{dez} & 4^{\mathrm{o}} & 7 \mathrm{dez} 518\end{array}$

Assim, com as datas calculadas de acordo com o calendário Juliano se pode estabelecer a atividade profética de Zacarias entre 520 e 518 a.C. Seria um

\footnotetext{
${ }^{157}$ Cf. J. G. BALDWIN, Ageu, Zacarias e Malaquias. São Paulo: Vida Nova, 1972, p. 23.

${ }^{158}$ Cf. R. PARKER; W. H. DUBBERSTEIN, Babylonian Chronology 626 B.C.-A.D. 45. In: SAOC 24 (1942), Chicago/Illinois: The University of Chicago Press, 1942, p. 23-24.

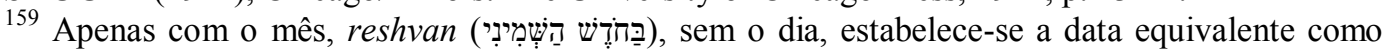
novembro ou dezembro de 520 a.C.; a Peshita fornece o dia como o primeiro dia, certamente tomando ḩōdeš (שָׁi்) como "mês" para significar a lua nova ou o primeiro dia do mês (cf. C. L. MEYERS; E. M. MEYERS, Haggai, Zechariah 1-8, p. 90). Para A. E. Hill (“Zechariah”, p. 23) a data equivalente para a primeira fórmula seria outubro ou novembro de 520 a.C.
} 
cálculo hipotético, pois as fórmulas que indicam as datas são escritas em terceira pessoa, o que sugere que uma pessoa, que não o profeta, responsável pela edição do livro, escreveu-as, posteriormente à revelação, como cabeçalho para os três textos que recolheu e juntou em Zc 1-8.

Nesse sentido, especificamente, a data informada em Zc 1,7 sugere que as experiências visionárias do ciclo de visões $($ Zc 1,7-6,15) ocorreram, todas, de uma só vez, em uma só noite. ${ }^{160}$ No entanto, a discrepância apresentada entre a fórmula de datação (cf. Zc 1,7), em terceira pessoa, e o início propriamente dito da primeira visão (cf. Zc 1,8), em primeira pessoa, sugere ser melhor libertar-se inteiramente da indicação cronológica de Zc 1,7, extraindo de cada visão, isoladamente, a situação em que foi recebida. ${ }^{161}$

Para embasar a ideia de que se deve libertar inteiramente da indicação cronológica de Zc 1,7, um estudo das visões se concentrou no contexto histórico, ${ }^{162}$ em vez de concentrar-se na exegese, para afirmar que haveria um cenário histórico distinto para cada visão e que estas configurações não seriam idênticas. Segundo a conclusão deste estudo, as experiências visionárias ocorreram em ocasiões diferentes, uma parte ainda na Babilônia e outra já em Jerusalém:

a) no momento da saída do exílio: as visões dos cavaleiros (cf. Zc 1,8-15), dos chifres (cf. Zc 2,1-4), do cordel (cf. Zc 2,5-9) e das carruagens (cf. Zc $6,1-8)$

b) um pouco antes do início da reconstrução do Templo: o oráculo em Zc 1,16-17, e talvez a citação em Zc 6,15a;

c) no primeiro tempo da reconstrução do Templo: as visões do candelabro (cf. Zc 4,1-14), a do rolo que voa (cf. Zc 5,1-4) e a do efá (cf. Zc 5,5-11).

Contudo, recomenda-se cautela na interpretação das visões sob o impulso histórico que as produziu. Problemas acarretados com a interpretação de Salmos individuais a partir de uma origem histórica que, embora tomada de boa fé, se

\footnotetext{
160 Assim pensa J. C. PAKALA (cf. "Short Contribution, A Librarian's Comments on Commentaries 31", p.49-53).

161 A localização temporal da redação da visão de Zc 5,5-11, pode ser pensada a partir da expressão "em toda a terra", no v.6f, como tendo ocorrido em Judá e Jerusalém no início do pós exílio (cf. K. GALLING, "Die Exilwend in der Sicht des Propheten Sacharja”. VT 2/1 (1952), p. 18-34).

${ }^{162}$ Cf. K. GALLING, "Die Exilwend in der Sicht des Propheten Sacharja", p. 18-36.
} 
mostrava falsa, levaram à rejeição firme desse entendimento. É certo imaginar que as oito visões de Zacarias formam uma unidade literária e uma progressão, mas nem a unidade nem a progressão refletem a realidade histórica em si, ao contrário, são as visões que precedem, e até permitem que a realidade histórica aconteça. Nesse sentido, as visões representariam reflexões teológicas altamente simbólicas de um processo de reorganização da sociedade judaica diante da oportunidade de viver uma nova era com o Templo reestruturado, um culto correto e com justiça. ${ }^{163}$

Sobre a questão se as visões ocorreram ou não em uma única noite, a quinta visão (cf. Zc 4,1-5) oferece um quadro diferente. Nela, o profeta inicia falando, em primeira pessoa, que o mensageiro voltou e o despertou de um sono (cf. Zc 4,1). Trata-se de uma experiência diferente que aponta para uma situação mais complexa da qual pouco se pode inferir.

$\mathrm{O}$ assunto pode ser examinado na ótica do estudo do comportamento dos sonhos. Pesquisas, neste campo, concluíram que uma pessoa pode, normalmente, ter uma série de sonhos numa mesma noite, cerca de quatro a seis. Os sonhos podem se concentrar em um único tema ou em assuntos diversos; podem também ocorrer em cores ou não (70 a 80 por cento são em cores). ${ }^{164}$

Assim, presumindo haver uma semelhança fundamental entre sonho e visão, e uma relação reconhecida pelos antigos gregos entre as palavras "sonho" $(\text { őv } \alpha \rho)^{165}$ e "visão" ou "vigília" (v̋ $\left.\alpha \rho \rho\right)$, e o reconhecimento desta relação pelos pesquisadores modernos, há uma evidência óbvia que sustenta a coerência básica dentro das visões de Zacarias. ${ }^{166}$

Parece bastante improvável que um redator inventasse uma data específica, ou que tivesse colocado uma data errada nas fórmulas de datação (cf. Zc 1,1.7; $7,1)$. Não há objeções formais para considerar Zc 1,7 como pertencente à primeira visão, mas se pertence ao corpus de todas as visões é outra questão. ${ }^{167}$ Nesse

\footnotetext{
${ }^{163}$ Cf. D. L. PETERSEN, Haggai and Zechariah 1-8, p. 110-125; F. S. SIQUEIRA, "Ml 1,6-14: A crítica profética ao culto do Segundo Templo e sua justificativa sob o aspecto teológico". Atualidade Teológica, 46 (2014), p. 194-206.

${ }_{164}$ Cf. D. L. PETERSEN, Haggai and Zechariah 1-8, p. 110-125.

${ }^{165} \mathrm{O}$ termo őv $\alpha \rho$ entra no contexto de comunicações não verbais com significado especial, ou seja, um sonho que se constitui num tipo de visão ou símbolo de uma realidade. Os sonhos comuns, como um mau sonho ou pesadelo, ou mesmo sonhos de implicações eróticas são expressos com termos diferentes (cf. J. LOUW, E. NIDA, “ővap”. In: LGPNT, p. 396-397).

${ }^{166}$ Cf. D. L. PETERSEN, Haggai and Zechariah 1-8, p. 110-125.

${ }^{167}$ Cf. C. JEREMIAS, Die Nachtgesichte des Sacharja, p. 13-21.
} 
sentido, é recomendável que cada visão seja analisada independentemente, buscando em cada uma os ecos dos acontecimentos do pós-exílio. É possível que as visões tenham sido reveladas, parte no exílio, parte no pós-exílio, ou seja, nem todas no mesmo lugar e ao mesmo tempo, tendo sido compiladas posteriormente. ${ }^{168}$

Possivelmente Zc 1,7 foi um "título" para a coleção do corpus das visões que representava, inicialmente um complexo por si só, introduzido com seu próprio cabeçalho. Quando mais tarde o prelúdio (cf. Zc 1,1-6) foi anexado ao complexo das visões, foi-lhe atribuído um outro cabeçalho e não retiraram Zc 1,7 que, naquele momento, se tornara indispensável. Esta segunda inserção pode não ter ocorrido ao mesmo tempo em que os oráculos, o que tanto evidencia a inserção como explica a diferença observada nos nomes próprios: "filho de Berek ${ }^{e} y \bar{a} h$ ",

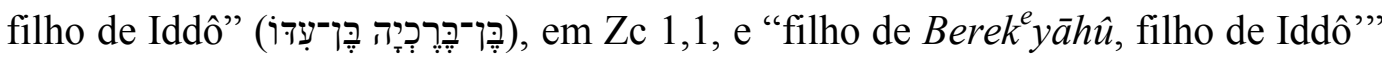

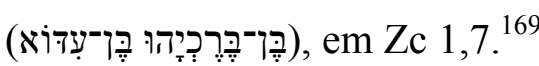

Como as visões em si não apresentam traços óbvios de edição, elas podem ser pensadas, conforme sugerido acima, como escritas em momentos diferentes, em estágio muito inicial de seu desenvolvimento, e reunidas sob o cabeçalho de Zc 1,7, provavelmente pelo próprio profeta que as teria relacionado com a reconstrução do Templo. ${ }^{170}$

Assim, também os oráculos, a exemplo das visões, podem ter tido origem em momentos distintos, um pouco antes do início dos trabalhos de reconstrução do Templo (cf. Zc 1,16-17 e, talvez, a citação em Zc 6,15) e na data indicada em Zc 7,1 , relacionada com a entrega da coroa confeccionada com a prata e o ouro trazidos da Babilônia (cf. Zc 6,9-15). ${ }^{171}$

Do mesmo modo, alguns oráculos teriam sido reunidos e apensados às visões, intercaladamente, depois de terem sido, originalmente, independentes (cf. 1,16.17; 2,6-13; 3,8-10; 4,6-10a; 6,9-15). Mais tarde, visões e oráculos teriam sido

\footnotetext{
${ }^{168}$ Cf. C. JEREMIAS, Die Nachtgesichte des Sacharja, p. 13-21.

${ }^{169}$ Os dois nomes próprios são grafados de duas formas distintas em Zc 1,1 e Zc 1,7: Berequiah e Berequiahu; Ido e Ido'. A primeira diferença é mais comum na língua hebraica, na qual muitos nomes possuem uma forma reduzida e uma forma longa; mais raro, no entanto, é o aparecimento da consoante álef no final do nome Ido', que reflete um estilo mais próximo da língua aramaica, podendo ser igualmente fruto de tradições distintas sobre o personagem, ou ainda poderia sugerir personagens distintos. Cf. C. JEREMIAS, Die Nachtgesichte des Sacharja, p. 13-21.

${ }^{170}$ Cf. R. MASON, The book of Haggai: Zechariah and Malachi, p. 56-58.

${ }^{171}$ Cf. K. GALLING, "Die Exilwend in der Sicht des Propheten Sacharja", p. 18-36.
} 
juntados sob a fórmula em $\mathrm{Zc}$ 1,7, e relacionados ao tema da reconstrução do Templo, provavelmente pelo próprio profeta. ${ }^{172}$

A terceira fórmula de datação (cf. Zc 7,1) encabeça uma última coleção de oráculos (cf. Zc 7-8). Esta fórmula não se encaixa com o versículo seguinte a ela (cf. Zc 7,2), sugerindo também tratar-se de uma inserção posterior, que teve por objetivo acoplar a coleção de versículos de Zc 7-8 ao conjunto das visões. ${ }^{173}$

Semelhante às três fórmulas de datação em terceira pessoa (cf. Zc 1,1.7; $7,1)$, um quarto simulacro de fórmula aparece nos capítulos finais, também em terceira pessoa (cf. Zc 7,8). Contudo, não se pode concluir que um único responsável tenha entregue: na primeira pessoa, os oráculos, introduzidos por Zc 7,4 e Zc 8,18; e na terceira pessoa, a introdução (cf. Zc 1,1-6), o ciclo de visões (cf. Zc 1,7-6,15) e os capítulos finais (cf. Zc 7,1-8,23). ${ }^{174}$

Os capítulos finais incluem uma alusão à profecia da época de sua compilação, indicando, como nas visões, a presença de outro profeta ao lado de Zacarias, além de Ageu, em dois versículos:

a) uma consulta da delegação de Betel aos sacerdotes e profetas do Templo, perguntando se deviam chorar e jejuar como faziam há anos (cf. Zc 7,3);

b) uma exortação endereçada àqueles que naqueles dias escutaram as palavras que foram entregues no tempo da atividade dos profetas, quando a pedra fundamental do Templo foi colocada (cf. Zc 8,9).

Zc 7,3 e Zc 8,9 sugerem que um compilador traçou um contraste entre passado e presente e apontou para as condições de pecado, de modo a conscientizar os ouvintes de seu tempo sobre as dificuldades passadas com a reconstrução do Templo como resultado da fé evocada.

Considerando as fórmulas de datação (cf. Zc 1,1.7; Zc 7,1) e a data de fundação do Templo, em setembro de 520 a.C. (cf. Ag 2,8), pode-se imaginar que houve um espaço de tempo transcorrido, ao final do qual um compilador exortou

\footnotetext{
${ }^{172}$ Cf. R. MASON, The book of Haggai: Zechariah and Malachi, p. 56-58.

${ }^{173}$ Cf. C. JEREMIAS, Die Nachtgesichte des Sacharja, p. 13-21.

${ }^{174}$ Para M. J. BODA ("From Fast to Feasts: The Literary Function of Zechariah 7-8”, p. 390-407), que encontra semelhança entre as fórmulas na terceira pessoa e as na primeira pessoa, a mesma pessoa se responsabilizou pela entrega dos oráculos introduzidos por Zc 7,4 e Zc 8,18 e pelo complexo maior formado pelo ciclo de visões e os capítulos finais.
} 
seus contemporâneos a enxergarem a aplicação das palavras de Zacarias aos problemas e às necessidades de seu tempo.

Assim, considerando também os oráculos justapostos às visões como um conjunto pertencente ao mesmo contexto dos acontecimentos do retorno, e tendo em vista a existência de referências cruzadas em vários lugares, pode-se concluir que este material foi integrado num momento muito próximo de sua proclamação original. ${ }^{175}$

Uma vez que nada pode ser dito com segurança sobre o período de atividade do profeta, apenas que algumas visões circularam originalmente na Babilônia, e que seu ministério pode remontar para antes de 520 a.C., é provável que os oráculos de Zc 1-8 tenham começado a ser recebidos antes da rebelião de Nidintu-Bel (cf. Zc 2,1-4), rapidamente debelada e interrompida em 522 a.C., mas que acabou por se estender através da rebelião menor de Araka, vencida em novembro de 521 a.C. (cf. Zc 1,11). Em vista disso, é provável que Zacarias tenha acompanhado o grupo de retorno a Jerusalém, liderado por Zorobabel e Josué, na virada de 521 a 520 a.C. ${ }^{176}$

De acordo com as fórmulas de datação, é possível que a coleção de visões tenha sido apresentada publicamente por Zacarias em 519 a.C. ${ }^{177}$ Assim, é provável que o processo de conclusão ou publicação do trabalho do profeta tenha ocorrido num curto espaço de tempo, após a última data informada, 7 de dezembro de 518 a.C. (cf. Zc 7,1).

E como a reconstrução do Templo foi a grande motivação para as profecias de Zacarias, e a cerimônia de dedicação do Templo não foi mencionada nem uma vez em Zc 1-8, supõe-se que a conclusão tenha ocorrido antes de primeiro de abril de 515 a.C. (cf. Esd 6,14). ${ }^{178}$ Neste caso, Zacarias não teria vivenciado, pelo menos em seu papel de profeta, a conclusão do Templo. ${ }^{179}$ Contudo, as referências de Esdras ao profeta (cf. Esd 5,2; 6,13-22) sugerem que

\footnotetext{
${ }^{175}$ Cf. C. L. MEYERS; E. M. MEYERS, Haggai, Zechariah 1-8, p. xliv-xlvii.

${ }^{176}$ De acordo com K. GALLING (cf. "Die Exilwend in der Sicht des Propheten Sacharja", p. 1836), pode ter havido um primeiro retorno em 538 a.C. sem autorização plenamente válida da Babilônia, a visão de Zc 2,1-4 dos ferreiros seria uma referência aos babilônios que haviam sabotado esse primeiro retorno e deveriam ser castigados [cf. Ag 2,7; Esd 4,3]) e os retornos tiveram início em 520 a.C.).

${ }^{177}$ Cf. K. GALLING, "Die Exilwend in der Sicht des Propheten Sacharja", p. 18-36.

${ }^{178}$ Cf. C. L. MEYERS; E. M. MEYERS, Haggai, Zechariah 1-8; A. E. “Zechariah”, p. 103-118.

${ }^{179}$ Cf. D. L. PETERSEN, Haggai and Zechariah 1-8, p. 110-125.
} 
ele continuou a apoiar e incentivar a conclusão do Templo e participou da dedicação do Templo na celebração da festa da Páscoa, em 515 a.C.

\section{2.}

\section{Considerações literárias}

De modo geral, o $\mathrm{M}^{\mathrm{L}}$ de $\mathrm{Zc}$ 1-8 é claro e livre de erros, que poderiam indicar que houve um processo de cópias de manuscritos ao longo do tempo. As visões, particularmente, não apresentam traços óbvios de edição, provavelmente porque foram escritas de acordo com seu desenvolvimento. $\mathrm{O}$ sentido gramatical parece, quase sempre, evidente, apresentando problemas, somente algumas vezes, quanto ao que o profeta pretendeu dizer. ${ }^{180}$

Assim, pode-se considerar o $\mathrm{M}^{\mathrm{L}}$ deste livro muito bem preservado e relativamente livre de problemas textuais. Isto não significa que não haja questões polêmicas para o debate, pois, ocasionalmente, pode-se deparar com um caso obscuro e de difícil interpretação por causa do vocabulário simbólico ou por causa da sintaxe discrepante (cf. Zc 2,8.9; 4,10b; 5,6). ${ }^{181}$

A LXX é geralmente confiável, embora às vezes se mostre um testemunho que interpreta e expande o $\mathrm{M}^{\mathrm{L}}$. Algumas partes do livro são atestadas por fragmentos e manuscritos de Qumran (cf. Zc 1,4-6.9-10.13-14; 2,10-14; 3,2-10; $4,1-4 ; 5,8-11 ; 6,1-5 ; 8,2-4.6-7)$, que apresentam apenas pequenas variações textuais de significado entre o $\mathrm{M}^{\mathrm{L}}$ e Qumran. De modo geral, pode-se dizer que os manuscritos de Qumran apoiam o texto hebraico subjacente ao $\mathrm{M}^{\mathrm{L}}{ }^{182}$

Os capítulos podem apresentar divergência de numeração em relação ao $\mathrm{M}^{\mathrm{L}}$, o que acontece, por exemplo, com o capítulo segundo, que no hebraico enumera-se Zc 2,1-4 e Zc 2,5-17 (seguido pela NAB e TEB), e na LXX é, respectivamente, Zc 1,18-21 e Zc 2,1-3. Neste trabalho será seguida a numeração do texto hebraico. ${ }^{183}$

\footnotetext{
${ }^{180}$ Cf. M. BUTTERWORTH, "Zacarias", p. 1298; M. M. PAZDAN, “Zacarias”, p. 155-156; R. MASON, The Book of Haggai, Zechariah and Malachi, p. 56-58; A. E. HILL, "Zechariah", p. 103-118; J. G. BALDWIN, Ageu, Zacarias e Malaquias, p. 47.

${ }^{181}$ Cf. J. G. BALDWIN, Ageu, Zacarias e Malaquias, p. 47.

182 Cf. A. E. HILL, "Zechariah", p. 103-118; C. L. MEYERS; E. M. MEYERS, Haggai, Zechariah 1-8, p. liv-lvii.178-227.

${ }^{183}$ Cf. M. BUTTERWORTH, “Zacarias”, p. 1298; M. M. PAZDAN, “Zacarias”, p. 155-156.
} 
Embora o autor ou editor demonstre ter feito um arranjo cuidadoso do texto, a dificuldade encontrada na interpretação do livro originou propostas de reorganização de algumas partes. A Bíblia de Jerusalém, por exemplo, sobre Zc 3, insere o v. 5 entre os vv. $4 \mathrm{a}$ e $4 \mathrm{~b}$, e informa em nota de rodapé, que estaria tentada a inserir o v.8 no meio do v.9, não o fazendo porque não há apoio de nenhum testemunho para a transposição. E, em Zc 4, muda a posição dos versículos, apresentando os vv. 6b-10a após o v.14. A NAB e a TEB reorganizam apenas Zc 4, ordenando os versículos da seguinte forma: a NAB: Zc 4-10, 1-3, 11-14, e a TEB: Zc 4,1-6a, 10b-14, 6b-10a. ${ }^{184}$

Há um consenso em dividir Zc 1-8 em três partes, segundo as fórmulas de datação: introdução (cf. Zc 1,1-6), ciclo de visões (cf. Zc 1,7-6,15) e oráculos sobre o jejum (cf. Zc 7-8). A introdução parece estabelecer a continuidade entre a geração passada e os retornados, de forma a servir de espelho para aqueles que voltaram para reconstruir o Templo.

As visões constituem o principal gênero literário de $\mathrm{Zc} 1-8$ e são entremeadas de oráculos (cf. Zc 1,7-6,15) que funcionam como respostas. Os capítulos finais (cf. Zc 7,1-8,23) apresentam uma coleção distinta de oráculos. Provavelmente, um material foi adicionado às visões e aos oráculos, ampliando a coleção para estabelecer a forma definitiva do texto, talvez para revisão em face de um contexto político em mudança. ${ }^{185}$

Escritas em estilo autobiográfico, que inclui diálogos de pergunta e resposta entre o mensageiro de YHWH e o profeta, e descrições de cenas extraordinárias, as visões, em geral, seguem determinado padrão, com exceção da quarta visão, sobre as vestes sujas de Josué, que possui estrutura e linguagem peculiares. Por isso, Zc 3,1-7, a despeito de sua forma, é uma visão profética e parte da sequência visionária do profeta, em geral é excluída da coleção. ${ }^{186}$

Entre os argumentos para a exclusão, o principal é a ausência da figura do mensageiro, presente nas outras visões, uma vez que o verbo "mostrar" (רָָָה) não indica o sujeito da ação claramente. A Peshita supõe que seja um anjo, entretanto a possibilidade de ser o próprio YHWH é um ponto de vista refletido pela LXX e pela Vulgata. Algumas outras diferenças são apontadas:

\footnotetext{
${ }^{184}$ Cf. M. BUTTERWORTH, "Zacarias”, p. 1298; M. M. PAZDAN, “Zacarias”, p. 155-156.

${ }^{185}$ Cf. M. BUTTERWORTH, "Zacarias", p. 1298; M. M. PAZDAN, “Zacarias", p. 155-156.

${ }^{186}$ Assim entendem C. L. MEYERS; E. M. MEYERS (cf. Haggai, Zechariah 1-8, p. liv-lv.178227), que excluem a visão do ciclo.
} 
a) o profeta é um ator na cena e não uma testemunha;

b) não é utilizada a expressão “E eis que!", que complementa o verbo;

c) o esquema literário não possui as quatro partes caracterizadas por

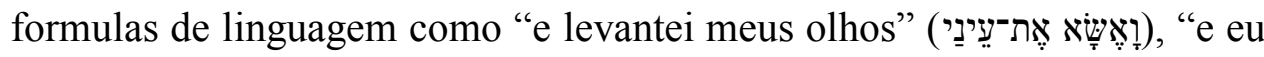

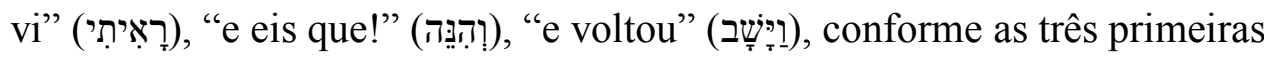
e as três últimas visões;

d) os personagens e objetos são reais;

e) a cerimônia de investidura retrata uma cena de corte celestial, vista somente vagamente em outras partes do livro. ${ }^{187}$

Alguns oráculos, que aparecem entre as visões, podem ser resultado da escrita do próprio profeta, outros não. Os oráculos podem ser divididos em dois blocos, os que se encontram espalhados ao longo das visões, e os que se concentram nos dois últimos capítulos, parecendo ter objetivos diferentes.

Nas visões, os oráculos parecem responder às questões da visão à qual estão anexados, extraindo implicações e até corrigindo-as. No final do livro, os oráculos incluem uma argumentação que, embora eloquente, se apresenta de forma mais admonitória que nos oráculos das visões. Além disso, os oráculos em Zc 7-8 parecem apresentar o profeta como menos idealista, realçando sua condição de profeta. São oráculos que sugerem um foco particular na transição entre um tempo de lamentação e um tempo de celebração que, sem dúvida, ocorrerá em Jerusalém. ${ }^{188}$

Em relação a estes oráculos finais, questiona-se se Zc 7-8 não deveria ser considerada uma unidade em separado. Há, para isso, dois argumentos, um formal e um de conteúdo. $\mathrm{O}$ argumento formal seria a existência de uma fórmula que inclui uma data e abre os capítulos sete e oito como se fosse um cabeçalho (cf. Zc 7,1). O argumento de conteúdo é a pergunta feita em um capítulo (cf. Zc 7,3), e respondida somente no capítulo seguinte (cf. Zc 8,19), sobre se deveriam manter o jejum pela destruição do Templo, uma vez que haviam iniciado os trabalhos de reconstrução. ${ }^{189}$

Os argumentos não são convincentes para caracterizar Zc 7-8 como uma unidade. Primeiro, a fórmula em Zc 7,1 pode ter relação somente com $\mathrm{Zc} 7$.

\footnotetext{
${ }^{187}$ Cf. C. L. MEYERS; E. M. MEYERS, Haggai, Zechariah 1-8, p. liv-lvii.178-227.

${ }^{188}$ Cf. D. L. PETERSEN, Haggai and Zechariah 1-8, p. 110-125.

${ }^{189}$ Cf. E. ASSIS, E., "The Structure of Zechariah 8 and Its Meaning". JHS 12/12 (2012), p. 1-18.
} 
Segundo, dentro de um capítulo com material tão diverso, apenas Zc 8,19 teria relação estreita com $\mathrm{Zc} 7 \mathrm{e}$, mesmo assim, isto não parece ser uma resposta à pergunta, pois apenas promete que os dias de jejum se tornarão dias de alegria. Além disso, entende-se que a resposta sobre a questão do jejum poderia estar em Zc 7,4-14. ${ }^{190}$

De modo diverso, pode-se pensar que Zc 7-8 liga-se bem aos versículos de abertura do livro (cf. Zc 1,1-6) e fornece com esta introdução uma ideia conveniente para a coleção maior do ciclo de visões e oráculos (cf. Zc 1,7-6,15), colocado com a mesma estrutura. ${ }^{191}$

\section{3.}

\section{Hipóteses redacionais}

Apesar da organização do livro em seções bem definidas através de fórmulas de datação, há uma grande dificuldade em formular uma hipótese redacional fechada para de Zc 1-8. Sua seção maior, formada por uma coleção de visões, é entremeada por oráculos que se espalham ao longo do ciclo. Estes oráculos são, em geral, considerados como composições separadas das visões, com contexto próprio e autoria independente. ${ }^{192}$

Uma série destes oráculos ${ }^{193}$ pode ser identificada pelo uso de linguagem típica de oráculos proféticos do tipo "Assim disse YHWH dos Exércitos"

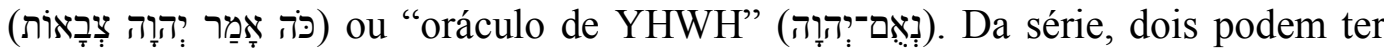
participado, em alguns casos até integralmente, da visão e, portanto, em um estágio inicial, principalmente Zc 2,8-9 e Zc 5,4. São oráculos que não usam

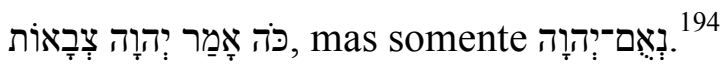

Três oráculos se destacam, Zc 2,10-17, 4,6b-10a e 6,9-15. ${ }^{195} \mathrm{O}$ primeiro, Zc 2,10-17, aparece depois da terceira visão (cf. Zc 2,5-9), que se passa claramente em Jerusalém, com o homem com o cordel para medir a cidade.

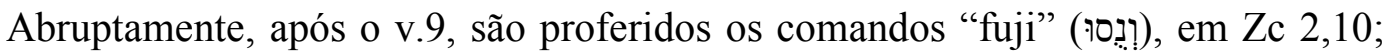

\footnotetext{
${ }^{190}$ Cf. E. ASSIS, E., "The Structure of Zechariah 8 and Its Meaning", p. 1-18.

${ }^{191}$ Cf. P. R., ACKROYD, "The book of Haggai and Zechariah I-VIII", p. 151-156.

${ }^{192}$ Cf. C. L. MEYERS; E. M. MEYERS, Haggai, Zechariah 1-8, p. 172-178.

${ }^{193}$ Cf. Zc 1,14b-17; 2,8-9; 2,10-16; 4,6b-10a; 5,4; 6,9-15.

${ }^{194}$ Cf. M. J. BODA, The Book of Zechariah, p. 16-23.

${ }^{195}$ Para J. W. ROTHSTEIN (cf. "Die Nachtgesichte des Sacharja Studien zur Sacharjaprophette und zur judischen Geschichte im ersten nachexiloischen". In: BWAT 8 (1910), p. 146-154), os oráculos em Zc 6,9-15 seriam continuação da sexta visão, Zc 5,1-4.
} 


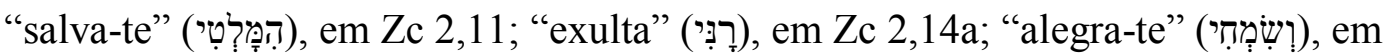
Zc 2,14b. Os imperativos são dirigidos aos que ainda permaneciam no exílio, ou seja, muda-se para um cenário novo, diferente da visão do cordel (cf. Zc 2,5-9).

Zc 2,10-17 é considerado, muitas vezes, como complemento das três primeiras visões (cf. Zc 1,7-17; 2,1-4; 2,5-9). Este oráculo, atribuído a Zacarias, funciona como uma revisão retrospectiva das três primeiras visões, na medida em que o profeta volta sua preocupação para a restauração do Templo. A dificuldade está em discernir o processo pelo qual ele foi incluído no ciclo de visões e se foi escrito antes ou depois das visões. ${ }^{196}$

O segundo, Zc 4,6b-10a, quebra a sentença maior ao meio (Zc 4,1-14). Transpondo-se Zc 4,6b-10a para após a visão Zc 3,1-14, obtém-se uma estrutura semelhante a Zc 3,1-10. ${ }^{197}$ Somente Zc 3,1-10 e Zc 4,6b-10a mencionam alguém e, em ambos os textos, se observa uma tendência a uma situação mais ideal do que real. As partes históricas contidas em Zc 4,6b-10a estão bem integradas à visão à qual se encontram anexadas, Zc 4,1-5. ${ }^{198}$

No terceiro oráculo, o conteúdo de Zc 6,9-15 destoa da visão (Zc 6,1-8) ao mudar a punição da Terra do Norte, para focar em um grupo de retornados vindo da Babilônia com ofertas para o Templo. Com a ausência de um poder civil, o editor acrescentou posteriormente o nome de Josué no ponto onde o oráculo citava Zorobabel (cf. Zc 6,11). ${ }^{199}$

Além disso, esses três oráculos se destacam por mudança de ouvinte (cf. Zc 2,10-17), por uma ruptura textual (Zc 4,6b-10a), e por mudança de conteúdo (cf. Zc 2,5-9), e ainda possuem diferentes destinatários, respectivamente, a comunidade que ainda permanecia no exílio, incentivando seus membros a fugir da Babilônia; Zorobabel, descrevendo sua liderança na reconstrução do Templo; Josué e outros que haviam retornado recentemente do exílio. ${ }^{200}$

\footnotetext{
${ }^{196}$ Cf. C. L. MEYERS; E. M. MEYERS, Haggai, Zechariah 1-8, p. 172-178.

197 Cf. P. J. RIVAS, “Zacarias”. In: S. G. OPORTO; M. S. GARCÍA (orgs.), Comentário ao Antigo Testamento II. São Paulo: Ave Maria, 1997, p. 373-387; M. M. PAZDAN, "Zacarias”, p. 155-167.

${ }^{198}$ Cf. C. L. MEYERS; E. M. MEYERS, Haggai, Zechariah 1-8, p. 265-277.

${ }^{199}$ Cf. P. J. RIVAS, “Zacarias”, p. 373-387.

${ }^{200}$ Cf. D. L. PETERSEN, Haggai and Zechariah 1-8, p. 110-125.
} 
Observa-se ainda que duas características de linguagem e estilo ligam $\mathrm{Zc}$ 2,10-17; 4,6b-10a e 6,9-15, ao mesmo tempo em que as distinguem de outros oráculos: ${ }^{201}$

a) os três contêm a fórmula profética: "E reconhecereis que YHWH dos

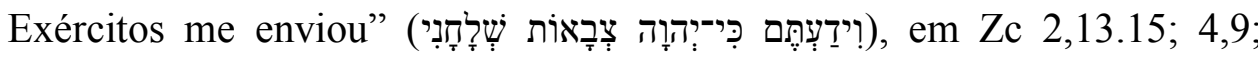
6,15

b) embora empreguem as fórmulas oraculares típicas "Assim disse YHWH

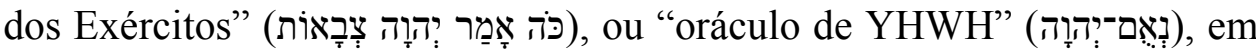
Zc 2,8-9 e Zc 5,4, dois contêm fórmula diferente "E veio a mim a palavra

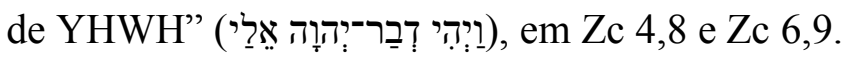

Essa última fórmula aparece também em Zc 7,4 e Zc 8,18, forjando uma conexão entre o ciclo de visões (cf. Zc 1,7-6,15) e os capítulos finais do livro (cf. Zc 7-8). O uso da primeira pessoa, nestas quatro fórmulas, sugere que estes oráculos foram extraídos de uma coleção criada pelo profeta, que põem em destaque um núcleo original em $\mathrm{Zc} 7-8 .^{202}$ As quatro fórmulas proféticas na terceira pessoa (cf. Zc 1,1.7; 7,1.8) e duas na primeira (cf. Zc 7,4; 8,18), ao longo de todo o livro, enfatizam e comprovam a presença do profeta e sua participação na elaboração da escrita do livro e a existência de outro redator ao seu lado. ${ }^{203}$

Há quem veja a existência de sinais e ecos de edição ou revisão como parte de um processo de integração de vários materiais em Zc 1-8. Um exemplo é a conexão feita entre a introdução (cf. Zc 1,1-6) e a primeira visão (cf. Zc 1,7-15). Um sinal desta conexão seria estabelecido através da declaração de que YHWH cumprirá sua parte da aliança quando diz "retornai a mim que eu retornarei a vós"

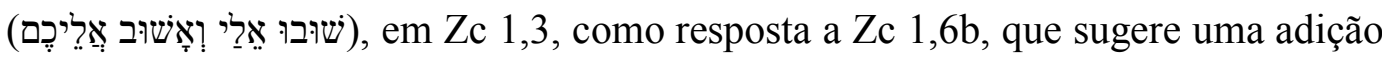
redatorial, e refere-se à situação atual de Zacarias e da comunidade. Eles teriam aprendido com o passado e aceitaram o convite para voltar e renovar a aliança com YHWH para reconstruir o Templo. O eco que estabeleceria esta conexão

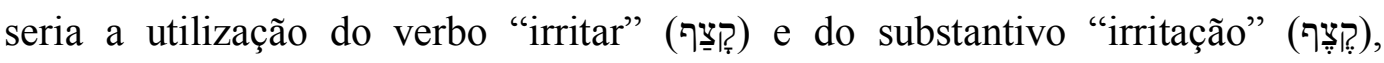

\footnotetext{
${ }^{201}$ Cf. M. J. BODA, The Book of Zechariah, p. 16-23.

${ }^{202}$ Cf. M. J. BODA, The Book of Zechariah, p. 16-23.

${ }^{203}$ Cf. J. G. BALDWIN, Ageu, Zacarias e Malaquias, p. 68-69.74.114-115.117.118.
} 
quando YHWH fala de sua irritação (cf. Zc 1,2.15), e do verbo "proclamar" (קָָרא), quando Ele fala da proclamação do profeta ao povo (cf. Zc 1,4.14.17). ${ }^{204}$

Estes sinais e ecos examinados na primeira visão (cf. Zc 1,8-17) estariam repetidos nos oráculos em outros lugares ao longo de Zc 1-8. Talvez se possa concluir com isso que o diálogo e os oráculos desta primeira visão foram moldados de acordo com os encontrados na introdução (cf. Zc 1,1-6), no ciclo de visões (cf. Zc 1,7-6,15) e nos capítulos finais (cf. Zc 7-8). ${ }^{205}$

No entanto, não existem ligações significativas entre a introdução ao livro (cf. Zc 1,1-6) e as visões, exceto com a quarta visão (cf. Zc 3,1-10), uma vez que ambas empregam: o verbo "proclamar" (קָרָא) em Zc 1,4 e Zc 3,10; o substantivo

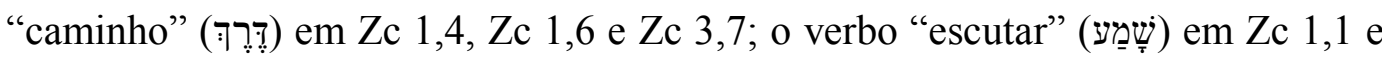
Zc 3,8; o substantivo "servo" (עֶֶר) em Zc 1,6 e Zc 3,8. . $^{206}$

De forma diferente, observam-se elos significativos entre algumas visões, conforme abaixo:

a) entre a primeira e a oitava: nas imagens de grupos de cavalos coloridos em manobras militares, com utilização do verbo “percorrer” (הฺָָ); b) entre a terceira e a quinta: no foco em figuras de liderança (Josué e Zorobabel) e nas referências a elementos sacerdotais (roupas, candelabros, sete olhos e oliveiras);

c) entre a primeira, a quinta e a oitava: únicos lugares onde aparecem a expressão "toda a terra" (כלָדָָָָרָץ) com sentido cósmico (cf. Zc 1,11; $4,10.14 ; 6,5)$;

d) entre a primeira, a terceira, a quinta e a oitava: apresentam a única utilização da raiz do verbo "repousar" (עֵַָ) em Zc 1,8.10.11; 3,1.3.4.5.7; 4,14 , em referência (pelo menos na quarta e quinta visões) à posição da corte celestial divina.

Assim, pode-se pensar que as visões que apresentam estas conexões (primeira, quarta, quinta e oitava) e as que apontaram processo comum pelo qual foram juntadas no final (primeira e quarta), conforme visto acima, fazem parte de

\footnotetext{
${ }^{204}$ Cf. M. BUTTERWORTH, “Zacarias”, p. 1310-1313; M. J. BODA, The Book of Zechariah, p. 16-23.

${ }^{205} \mathrm{O}$ estudo de M. J. BODA (cf. The Book of Zechariah, p. 16-23) revelou quatorze palavras repetidas, que identificou como material suplementar no ciclo de visões e nos capítulos sete e oito finais.

${ }^{206}$ Cf. M. J. BODA, The Book of Zechariah, p. 16-23.
} 
um esforço literário comum colocado posteriormente em Zc 1,1-6; 1,7-17; 2,1017; 3,1-10; 4,1-14; 6,1-8; 6,9-15; 7,1-8-8,23 (ou 7,1-14; 8,14-23, se Zc 8,13 tiver sido colocado posteriormente).

Os pares formados pela segunda e terceira e pela sexta e sétima visões não apresentam conexões lexicais importantes, embora o primeiro par apresente ligações temáticas, compondo, em duas etapas, o programa de restauração dos oráculos da primeira visão ( $Z c$ 1,15 na segunda visão e Zc 1,16-17 na terceira). A sexta e sétima visões estariam ligadas entre si, estabelecendo o chamado para o arrependimento nos capítulos finais (cf. Zc 6,15).

Os critérios apresentados acima apontam para uma conexão entre os materiais textuais e, com isso, a possibilidade de ter havido dois relatos autobiográficos que envolviam experiências visionárias e não visionárias, oráculos, sermões e relatos de um "ato-sinal". ${ }^{207}$ O responsável pela redação final juntou esse material todo e imitou uma fórmula profética de Zacarias "E veio a

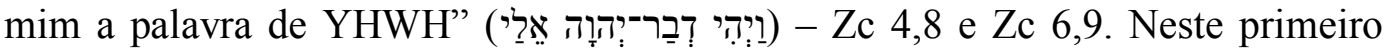
trabalho editorial, muito do livro atual foi elaborado em conjunto (cf. Zc 1,1-6; $1,7-17 ; 2,10-17 ; 3,1-10 ; 4,1-4 ; 6,1-8 ; 6,9-15 ; 7,1-14 ; 8,14-23)$. É provável que as visões de Zc 2,1-9 e Zc 5,1-11 tenham sido adicionadas posteriormente, embora estreitamente conectadas com o tema e os oráculos acoplados às visões, talvez como parte da edição em Zc 8,1-1.

\section{4 .}

\section{Estrutura geral do livro}

O livro de Zacarias possui conteúdo bem estruturado através de fórmulas de datação (cf. Zc 1,1.7; 7,1) consideradas marcadores organizacionais que dividem o texto em três seções básicas: uma introdução (cf. Zc 1,1-6), uma coleção de visões (cf. Zc 1,7-6,15) e uma coleção de discursos (cf. Zc 7-8). ${ }^{208}$

\footnotetext{
${ }^{207}$ M. J. BODA (The Book of Zechariah, p. 380-413) chama "ato sinal" uma forma de profecia usualmente composta de três partes: exortação, execução e explicação. Por exemplo, em Zc 6,9-15

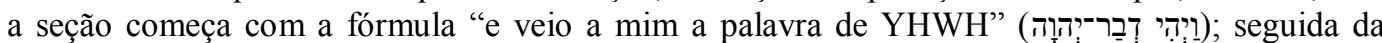
exortação em que é ordenado que o profeta execute uma ação, em geral envolvendo itens do dia a dia (vv.10-11); depois a execução apresenta um relato do profeta realizando a ordem dada (v.1214); e no final, a explicação de YHWH com o significado da ação (v.15).

${ }^{208}$ Cf. J. G. BALDWIN, Ageu, Zacarias e Malaquias, p. 47-48.
} 
No entanto, uma segmentação que levou em consideração Zc 1-14 apresentou as seguintes seções: a) oráculos com exortação (cf. Zc 1,1-6); b) coleção de visões (cf. Zc 1,7-6,8); c) ação simbólica executada pelo profeta (cf. Zc 6,9-15); d) oráculos com instruções (cf. Zc 7-8); e) pares de encargos (cf. Zc 9-14). ${ }^{209}$

O aumento do número de seções se dá com Zc 6,9-15, com fórmula de introdução própria (cf. Zc 6,9; cf. também Zc 4,8; 7,4; 8,1.18), localizado entre a coleção de visões (cf. Zc 1,7-6,8) e os capítulos finais (cf. Zc 7-8), que são encabeçados por fórmulas de datação, o texto antecedente por Zc 1,7 e o subsequente por Zc 7,1. ${ }^{210}$

Interpreta-se Zc 1-14 como um díptico, tendo Zc 6,9-15 como dobradiça principal (coluna vertebral do díptico), com as laterais deste díptico formando outros dípticos com Zc 3,1-10 e Zc 11,1-17 como dobradiças, respectivamente, das visões noturnas e o peso das obrigações com o luto e a celebração. Zc 6,9-15 compartilha com Zc 3,1-10 e Zc 11,1-17 um conjunto de características formais e temáticas, com o profeta participando em cada uma delas do comissionamento do Messias para sua tarefa sacerdotal real: coroação, investidura e ofício teocrático.

O tratamento dado a Zc 6,9-15, como uma seção especial, dividiu Zc 1-8 em quatro seções e não em três, conforme usualmente considerado. Assim, a estrutura de três dobradiças de Zc 1-8 ficaria da seguinte forma: prelúdio, Zc 1,16; ciclo de visões, Zc 1,7-6,1-8; investidura da coroação, Zc 6,9-15; epílogo, Zc $7,1-8,23 .^{211}$

Outra interpretação também divide Zc 1-8 em quatro seções. Apesar de se admitir que a divisão de Zc 1-8 está "bem à vista", marcada por suas fórmulas de datação (cf. Zc 1,1.7; 7,1), uma análise literária identificou uma estrutura quiástica subjacente às duas metades da profecia de Zacarias, Zc 1-8 e Zc 9-14. Isto dividiu a unidade em quatro seções: introdução (cf. Zc 1,1-6), coleção de visões (cf. Zc 1,7-6,15), mensagens ocasionadas pela pergunta sobre o jejum (cf. Zc 7,1-

\footnotetext{
${ }^{209}$ Cf. M. G. KLINE, “The Structure of the Book of Zechariah”. In: JETS, 34/2 (1991), p. 179193.

${ }^{210}$ Cf. M. G. KLINE, "The Structure of the Book of Zechariah", p. 179-193.

${ }^{211}$ Para M. G. KLINE ("The Structure of the Book of Zechariah", p. 179-193), Zc 1-14 foi planejado para dar destaque à futura vinda do Messias, ordenada para seu sacrifício sacerdotal e sua subsequente glória. Os principais pontos de articulação do arranjo que domina o texto seriam o tema do sacerdote-rei messiânico. Para J. G. BALDWIN (Ageu, Zacarias e Malaquias, p. 111), a interpretação de que o texto de Zc 6,9-15 seria uma referência a um Messias não está superada, a dúvida subsiste porque é o único texto que deixa claro que o rei davídico seria um sacerdote.
} 
8,19) e conclusão em que o mundo inteiro anseia por YHWH (cf. Zc 8,20-23). A estrutura quiástica foi vista como comprovação da unidade de Zc 1-14, ligando as visões, os oráculos e os sermões. Contudo, neste trabalho, será apresentada apenas a estrutura quiástica de Zc 1-8, conforme esquema abaixo: ${ }^{212}$

Prelúdio: Zc 1, 1-6 - Chamada ao arrependimento

\section{Ciclo de visões:}

a Zc 1,7-17 - visão dos cavaleiros e cavalos coloridos percorrendo a terra $b$ Zc 2,1-4 - visão dos 4 chifres e 4 ferreiros

$b$ Zc 2,5-17 - visão do homem com cordel e Jerusalém sem muros c Zc 3,1-10 - visão das vestes de Josué, Estado teocrático c Zc 4,1-14 - visão do candelabro e das duas oliveiras

$b$ Zc 5,1-4 - visão do rolo que voa e a maldição para ladrão e perjuro

$b$ Zc 5,5-11 - visão do efá e remoção da iniquidade

$a$ Zc 6,1-15 - visão dos carros que percorrem a terra

\section{Mensagens de jejum:}

$$
\begin{aligned}
& a \text { Zc } 7,1-3 \text { - inquérito } \\
& b \mathrm{Zc} 7,4-14 \text { - primeiro sermão } \\
& c \mathrm{Zc} 8,1-8 \text { - ditos da aliança } \\
& b \mathrm{Zc} 8,9-17 \text { - segundo sermão } \\
& a \mathrm{Zc} 8,18-19 \text { - a resposta }
\end{aligned}
$$

Final: Zc 8, 20-23 - Orai e buscai o Senhor

A introdução (cf. Zc 1,1-6) funcionaria como indicação da unidade do livro, com apelo ao arrependimento manifestado pelos profetas anteriores (cf. Zc $1,4)$, demonstrando a coerência temática e teológica da obra. ${ }^{213}$

Uma interpretação semelhante para o ciclo de visões (Zc 1,7-6,15) apresenta a estrutura quiástica de forma mais irregular, conservando a mesma para Zc 7,1-8,23, conforme apresentado abaixo: ${ }^{.14}$

\footnotetext{
${ }^{212}$ Cf. J. G. BALDWIN, Ageu, Zacarias e Malaquias, p. 47-48; A. E. HILL, "Zechariah”, p. 5764.

${ }^{213}$ Cf. J. G. BALDWIN Ageu, Zacarias e Malaquias, p. 47-48; A. E. HILL, “Zechariah”, p. $57-$ 64.

${ }^{214}$ Cf. A. E. HILL, “Zechariah”, p. 14-64.
} 


\section{Ciclo de visões:}

a Zc 1,7-17 - visão dos cavaleiros e cavalos coloridos percorrendo a terra

$b$ Zc 2,1-4 - visão dos 4 chifres e 4 ferreiros

$b$ Zc 2,5-17 - visão do homem com cordel e Jerusalém sem muros

c Zc 3,1-10 - visão das vestes de Josué, Estado teocrático

$d$ Zc 4,1-14 - visão do candelabro e das duas oliveiras

$b$ Zc 5,1-4 - visão do rolo que voa e a maldição para ladrão e perjuro

$b$ Zc 5,5-11 - visão do efá e remoção da iniquidade

$a$ Zc 6,1-15 - visão dos carros que percorrem a terra

Contudo, são consideradas outras estruturas temáticas, como a estrutura concêntrica com sete componentes do ciclo de visões (cf. Zc 1,7-6,15), com a exclusão de Zc 3,1-10. Nesse caso, as visões externas (Zc 1,7-17 e Zc 6,1-15) representam a situação em escala mundial; os pares de visões mais internas (Zc 2,1-4/2,5-17 e Zc 5,1-4/5,5-11) têm por tema a reestruturação de Jerusalém e Judá, bem como a eliminação de riscos externos e internos; e Zc 4,1-14 a dominação de YHWH no e sobre o mundo, conforme apresentação abaixo:.215

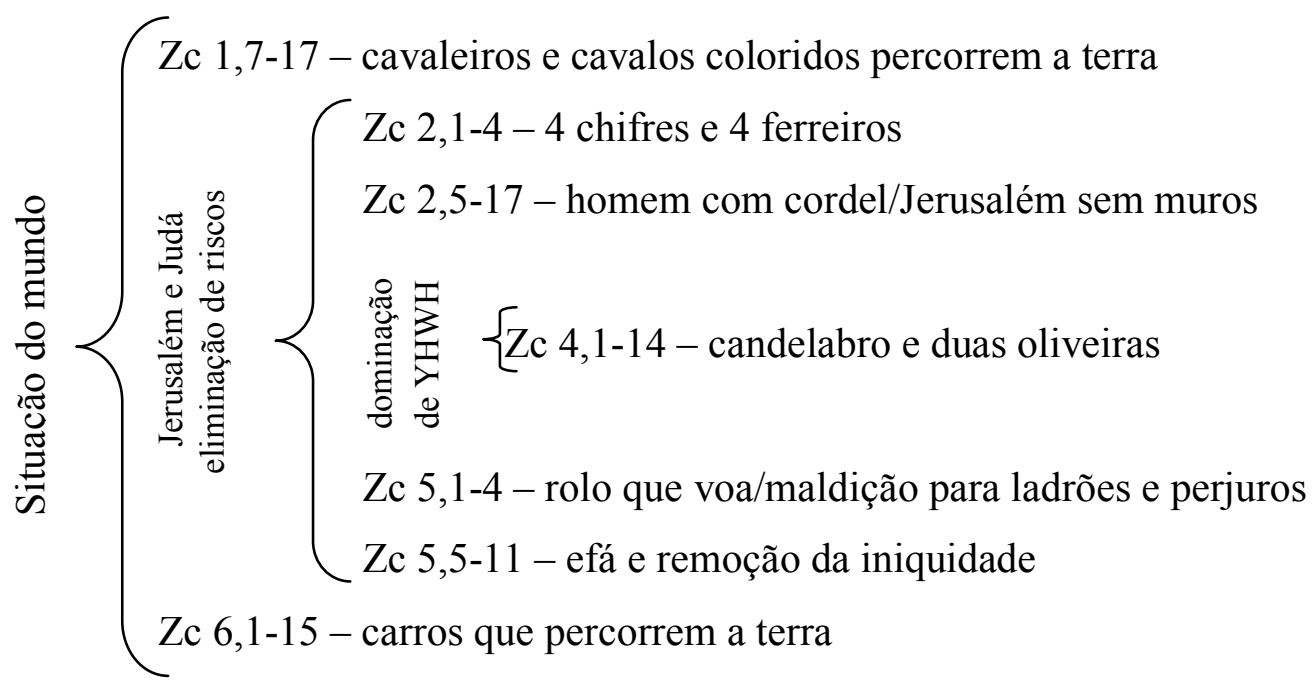

A estrutura quiástica sugere que Zacarias teria escrito, organizado e editado os próprios oráculos. ${ }^{216}$ Certamente, a estrutura auxilia o entendimento do livro, com o centro do quiasmo enfatizando a mensagem divina que aponta para os esforços de Zacarias em reorganizar a sociedade judaica a partir da iniciativa divina (cf. Zc 3,1-10), sob nova liderança (cf. Zc 4,1-14).

\footnotetext{
${ }^{215}$ Cf. M. HALLASCHKA, Haggai und Sacharja 1-8, p. 139-143.

${ }^{216}$ Cf. A. E. HILL, "Zechariah", p. 103-118.
} 


\section{4}

\section{Contexto social e religioso do retorno do exílio}

\section{1.}

\section{Acontecimentos anteriores ao retorno}

O Império Persa, aos poucos, se tornou o maior império do Oriente nos séculos VI a IV a.C. São obscuras as informações sobre como ocorreu a conquista da Palestina, do sul da Síria e da Babilônia. Sabe-se que, por volta de 538 a.C., Ciro II (559-530 a.C.) se tornou rei dos persas e medos. ${ }^{217}$

Conforme profetizado por Jeremias, deveriam passar "setenta anos" (cf. Jr 25,11-12; 29,10) para YHWH despertar o espírito de Ciro, rei da Pérsia, e encarregá-lo de construir-lhe um Templo (cf. $2 \mathrm{Cr} 36,23.24)$. Para a verificação do cumprimento da profecia, faz-se o cálculo dos setenta anos a partir 604 a.C. (quando Jeremias falou a primeira vez); ou de 597 a.C. (quando o primeiro grupo foi deportado para a Babilônia); ou ainda, de 587 a.C. (quando houve a principal deportação), e não se chega ao ano de 538 a.C., quando se realizou a profecia. Assim, setenta deve ser considerado um número simbólico, que sugere plenitude ou conclusão $(\mathrm{cf} . \mathrm{Zc} 7,4){ }^{218}$

Os setenta anos só fizeram sentido mais tarde e, talvez, por isso, os exilados o tenham visto como um sinal de que era tempo de retornar (cf. Zc 1,12). O retorno, então, foi intepretado, sob o ponto de vista do judaísmo, como uma revitalização das antigas tradições israelitas e, especialmente, jerusolimitanas. Dessa perspectiva judaica, os setenta anos são colocados em Esdras como referentes à conquista da Babilônia e seu domínio sobre os judeus, e não em relação à elevação de Ciro ao trono da Pérsia, em 557 a.C. (cf. Esd 1,2-4; 6,3-5). Assim, para os judeus, o primeiro ano de Ciro é 538 a.C. (cf. Esd 1,1), ano em que voltaram para YHWH que perdoa, dá esperanças para o futuro e promete nova aliança (cf. Jr 30,1-31,40). ${ }^{219}$

\footnotetext{
${ }^{217}$ Cf. E. S. GERSTENBERGER, Israel no tempo dos persas, p. 73-80; J. BRIGHT, A História de Israel. São Paulo: Paulinas, 1978, p. 487-488.

${ }^{218}$ Cf. A. L. LAFFEY, "1 e 2 Crônicas". In: D. BERGANT; R. J. KARRIS (orgs.), Comentário bíblico, v.2. São Paulo, 1989, p. 333-341.

${ }^{219}$ Cf. R. J. BURNS, "Esdras e Neemias". In: D. BERGANT; R. J. KARRIS (orgs.), Comentário bíblico, v. 2. São Paulo, 1989, p. 303-319.
} 
A documentação persa do edito, em versão aramaica, mencionada pelos autores de Esdras, é, provavelmente, um texto judaico e não um registro oficial (cf. Esd 1,2-4). Não parece que o imperador persa considerasse seu poder proveniente de YHWH, o Deus de Israel, pois no Cilindro de Ciro, o deus dos babilônios (Marduk) foi quem entregou a Babilônia nas mãos do rei. Apesar de os textos bíblicos enaltecerem a política de Ciro é improvável que babilônios contribuíssem com provisões para os viajantes e oferendas para YHWH. Pode ter sido apenas uma tentativa de equiparar o retorno ao êxodo, com o episódio de despojo de bens dos egípcios na saída do Egito (cf. Ex 12, 35-36).

A fidelidade ao testemunho bíblico do Cilindro de Ciro verifica-se com a ordem do imperador para que os retornados do exílio na Babilônia reconstruíssem Jerusalém e o Templo, conforme profetizara Isaías (cf. Is 44,28). Esdras, ainda em estilo formal, informa que serão devolvidos utensílios em ouro e prata retirados por Nabucodonosor, encontrados em Ecbátana, fortaleza situada na província da Média (cf. Esd 6,3-5). Contudo, em relato anterior, este testemunho não menciona tal devolução (cf. Esd 1,2-4) ${ }^{220}$

Embora Esdras e Neemias coloquem os chefes judaicos Zorobabel e Josué no contexto do reinado de Dario I (522-485 a.C.), o primeiro retorno deve ter ocorrido no breve reinado de Cambises (530-522 a.C.). A escolha por Dario I pode ter sido para afastar-se do reinado de Cambises, por causa das muitas desordens e revoltas deste governo. ${ }^{221}$

A estabilização do imenso império necessitava da colaboração de todos os antigos reinos e povos e, para isso, Ciro conquistou a confiança dos dominados ao respeitar sua cultura e suas tradições religiosas, fazendo com que os sacerdotes de Marduk e os discípulos de Isaías vissem a mudança com bons olhos (cf. Is 44,28; $45,1)^{222}$

A benevolência do Império Persa, permitindo o retorno dos exilados às suas terras e a prática do culto, pode ser explicada como estratégia governamental dos dominadores. O Egito, antigo inimigo dos mesopotâmios, permaneceu livre com Judá e Jerusalém submetidas e fazendo fronteira com este país. Judá e

\footnotetext{
${ }^{220}$ Cf. R. J. BURNS, “Esdras e Neemias, p. 303-319.

${ }^{221}$ Cambises é acusado de não ter respeitado a religião dos súditos, destruindo templos egípcios, contudo, segundo J. BRIGHT (A História de Israel, p. 494), a acusação não foi comprovada e os judeus não podem se queixar, pois o templo judaico de Elefantina foi poupado; cf. também R. J. BURNS, "Esdras e Neemias", p. 303.

${ }^{222}$ Cf. J. BRIGHT, A História de Israel, p. 489-491.
} 
Jerusalém poderiam servir como uma espécie de fortaleza não só para defesa do Império Persa, em situações de avanço dos egípcios, mas também como local ideal para alcançar e atacar o Egito. Se, de fato, o edito em aramaico é um documento oficial persa, pode-se pensar que Ciro o tenha publicado em 538 a.C. para incentivar a elite judaica exilada a retornar a Judá com o objetivo de viabilizar seu plano de domínio na região (cf. $2 \mathrm{Cr} 36,22-33$; Esd 1,2-4). ${ }^{223}$

Assim, o retorno de exilados garantiria a paz do Império Persa na região. Não se tratava de consideração pela consciência do outro ou por virtude social, mas da percepção de que com isso se poderia dominar melhor e de forma mais duradoura. Até porque o governo imperial limitava os povos dominados aos próprios interesses em constante alerta contra qualquer tipo de ameaça ao poder imperial persa e à coleta de impostos. ${ }^{224}$

A política de não interferência nos assuntos locais e costumes dos povos, respeitando suas tradições, ajudaram a garantir para a Pérsia a lealdade de muitas das nações recém-conquistadas. ${ }^{225}$ Inscrições dos primeiros representantes da dinastia aquemênida, nas línguas persa, elamita, babilônica e aramaico, em correspondências da administração central, atestam esse respeito. A língua aramaica se espalhou progressivamente neste período na Síria, Palestina e Egito, tornando-se língua oficial, substituindo, mais tarde, o hebraico na Palestina como língua popular. ${ }^{226}$

Mesmo com o tão falado retorno, a população continuava diminuta e pobre, com Jerusalém em ruínas (cf. Ne 7,4), o que não contribuía, em princípio, para a estabilidade da comunidade judaica. O cenário político não parecia alterado de acordo com as profecias do Trito Isaías (cf. Is 56,1-8), pois os judeus não

\footnotetext{
${ }^{223}$ Cf. J. KONINGS, A Bíblia sua origem e sua leitura. Vozes, 2014, p. 68-69. Ao investigar a hipótese de Jerusalém ter sido uma fortaleza, L. L. GRABLE ("Was Jerusalem a Persian Fortress?". In: G. N. KNOPPERS; L. L. GRABBE; D. FULTON (eds.), Exile and Restoration Revisited. London/New York: T\&T Clark, 2009, p. 128-137) deixa em aberto várias questões sobre esta cidade: se foi realmente importante estrategicamente para o Império Persa; se foi de fato capital da província; se guarnições persas, comuns em grandes centros urbanos em circunstâncias normais, eram frequentes na cidade; e até se houve realmente uma muralha como uma "parede substancial" ou se era apenas "uma parede parcialmente paliçada de madeira".

${ }^{224}$ Cf. H. DONNER, História de Israel e dos povos vizinhos, v. 2. São Leopoldo: Sinodal, 1986, p. 446; F. CRÜSEMANN, A Torá, teologia e história social da lei do Antigo Testamento. Petrópolis: Vozes, 1992, p. 471-474.

${ }^{225}$ Cf. J. BRIGHT, A História de Israel, p. 362; J. KONINGS, A Bíblia sua origem e sua leitura, p. 68-69.

${ }^{226}$ Cf. A. H. J. GUNNEWEG, História de Israel, dos primórdios até Bar Kochba e de Theodor Herzl até os nossos dias v. 2. São Paulo: Loyola, 2005, p. 222.
} 
estavam se deslocando para Judá e as nações não estavam adorando YHWH (cf. Is $56,8) .^{227}$

Com a morte de Ciro, seu filho Cambises (530-522 a.C.) anexou o Egito ao império em 525 a.C., morrendo antes de retornar à Babilônia. Dario I (522-486 a.C.) assumiu após depor Guamata, que tentara usurpar o poder. As rebeliões iniciadas ainda no tempo de Cambises e outras iniciadas depois continuaram afetando todo o império. Tinha-se a impressão que o Império Persa estava se desfazendo. $^{228}$

Talvez por isso, como parte da política imperial, grupos locais de liderança foram organizados e favorecidos, bem como instituições que contribuíssem para a estabilidade da nação. Alguns grupos de exilados retornaram entre 525 e 520/519 a.C., ou seja, entre os reinados de Cambises e Dario I, por causa das desordens, e ainda se esperava mais gente, conforme informam os discípulos de Isaías (cf. Is $56,8)$. É possível que as turbulências que ocorriam naquele momento no império tenham estimulado o aumento do número de retornados, que fugiam ou que simplesmente imigravam. O grupo de Zorobabel em 520 a.C. (cf. Zc 1,1.7) pode ser parte dessa onda de retorno. ${ }^{229}$

Zacarias, provavelmente, já se encontrava em Jerusalém estimulando a fuga para a cidade, conforme sua profecia que diz Eh! Eh! Fugi da terra do Norte - oráculo de Yhwh - (...) Eh! Sião, ${ }^{230}$ salva-te Tu que habitas com a filha da Babilônia (Zc 2,10a.11). ${ }^{231}$

Além dos grupos de fugitivos, chegavam a Jerusalém, em voltas escalonadas num período de pelo menos um século, grupos que livremente decidiram pela mudança. Em contrapartida, nem todos voltaram e, possivelmente outras pessoas se juntaram às caravanas de retorno, talvez com credenciais genealógicas nem sempre regulares (cf. Esd 2,59-63; Ne 7,61-65). As listas de legítimos pertencentes à comunidade judaica foram atualizadas por anciãos e sacerdotes durante o exílio na Babilônia. ${ }^{232}$

\footnotetext{
${ }^{227}$ Cf. J. BRIGHT, A História de Israel, p. 479-487; H. CAZELLES, História de Israel desde as origens até Alexandre Magno, p. 214.

${ }^{228}$ Cf. J. BRIGHT, A História de Israel, p. 493-499; H. CAZELLES, História de Israel desde as origens até Alexandre Magno, p. 215.

${ }^{229}$ Cf. A. H. J. GUNNEWEG, História de Israel, p. 224.

${ }^{230}$ Designando os exilados.

${ }^{231}$ Zc 2,10b é secundário.

${ }^{232}$ Cf. M. LIVERANI, Para além da Bíblia, história antiga de Israel. São Paulo: Paulus/Loyola, 2003, p. 313-316.
} 
Não houve um retorno para Israel somente de seu povo, mas também de grupos originários de diferentes lugares, Babilônia, Egito e territórios de antigo domínio assírio. Provavelmente, os que retornavam eram grupos de voluntários organizados, sustentados financeiramente pelas comunidades dessa diáspora que simpatizavam com a iniciativa. ${ }^{233}$

Alguns grupos podem ter regressado ainda no período babilônico, depois da anistia de Awil-Marduk; outros, em 538 a.C., com a política de permissão de Ciro. $^{234}$ O primeiro grupo pode ter vindo sob a liderança de Sasabassar, o "principe de Judá", provavelmente para indicar sua procedência davídica (cf. Esd 1,8). Poucos anos depois, outro grupo que chega a Jerusalém, liderado por Josué e Zorobabel, construiu um altar e celebrou a festa dos Tabernáculos e deu início à reconstrução do Templo (cf. Esd 3,11-13). ${ }^{235}$

Cabe ressaltar que nem todos os judeus exilados aproveitaram a oportunidade oferecida pelo Império Persa para voltar, muitos se encontravam estabelecidos, haviam reconstruído suas vidas e se sentiam adaptados. Não adiantou a proclamação dos discípulos do profeta Isaías de exortação para que o povo regressasse, pois YHWH, como um "pastor" estaria com eles com poder e cuidado amoroso (cf Is 40,9; cf. também Sl 23; Jó 10). ${ }^{236}$

E, no entanto, foram as escolas dos profetas Isaías, Jeremias e Ezequiel que fundamentaram a esperança do povo durante o exílio numa restauração nacional por meio de um novo rei Davi. A escola de Isaías havia comemorado antes da queda da Babilônia as vitórias de Ciro (cf. Is 44,28; 45,1). ${ }^{237}$ Para essa escola, Jerusalém, que será reconstruída, é o centro dessa perspectiva (cf. Is 40,9; 54,2 ) e haverá um novo reinado davídico (cf. Is 55,4). A escola de Jeremias favorece Sedecias (cf. Jr 23,5-6) e depois o corrige (cf. Jr 33,15-16). As visões de futuro da escola de Ezequiel distinguem o sacerdote, que deve ser sadoquita (de Davi e de Salomão), e o príncipe, de quem não é exigido ser israelita, em contradição com o Deuteronômio (cf. Jr 30,21; cf. também Dt 18,15). Reconhecese assim, antecipada e implicitamente, a autoridade estrangeira, sem perder a

\footnotetext{
${ }^{233}$ Cf. M. LIVERANI, Para além da Bíblia, história antiga de Israel, p. 331-333.

${ }^{234} \mathrm{Cf}$. M. LIVERANI, Para além da Bíblia, história antiga de Israel, p. 331-333.

${ }^{235}$ Cf. I. FINKELSTEIN; N. A. SILBERMAN, A Bíblia não tinha razão. São Paulo: Girafa, 2001, p. 397-404.

${ }^{236}$ Cf. J. J. COLLINS, "Isaías". In: D. BERGANT; R. J. KARRIS (orgs.), Comentário bíblico, v. 2, p. $11-44$.

${ }^{237}$ Segundo J. J. COLLINS ("Isaías", p. 11-44), nem todos os exilados judeus aceitaram prontamente um messias persa.
} 
esperança de que esse príncipe se torne, mais tarde, um rei Davi (cf. Ez 34,23; $37,24){ }^{238}$

Com esse espírito, os exilados seguiram em caravanas a Jerusalém, onde os sacerdotes sadoquitas tentaram conseguir uma posição dominante na sociedade judaica, enquanto os que preferiram permanecer na diáspora se faziam ouvir de onde estivessem. Nesse sentido, as questões internas da cidade passaram a ser as questões do judaísmo, e Jerusalém deixou de ser a cidade dos que nela habitavam para se tornar a cidade dos judeus de todo o mundo. ${ }^{239}$

\section{2.}

\section{Formação de grupos de liderança}

Provavelmente, a fuga apressada da Babilônia por causa das desordens que ocorreram por volta de 522 a.C. (cf. Zc 2,10a.11) tenham contribuído para a formação de uma comunidade bastante heterogênea. Este pode ter sido um dos principais problemas para a reorganização da comunidade judaica, pois os que fugiam eram pessoas que apenas procuravam melhores condições de vida, não estando, portanto, imbuídas das mesmas pretensões dos líderes judaicos. ${ }^{240}$

Um segundo problema foi deparar-se com a cidade destruída e uma população de pobres e miseráveis. Percebe-se a situação aflitiva e frustrante encontrada quando o profeta Zacarias pede que o povo "não despreze os humildes começos" (cf. Zc 4,10). Os exilados, recém-chegados a Jerusalém, enfrentaram anos de dificuldades, começando de novo numa terra, agora estranha, atormentados pela inclemência das estações (cf. Ag 1,9-11; 2,15-17). A cidade estava fracamente povoada e ainda em ruínas, décadas depois do exílio (cf. Zc $7,4)$. O profeta procurava estimular o povo a não desistir da luta. ${ }^{241}$

Um terceiro problema pode ter sido a má recepção feita aos que retornavam. Os que permaneceram na terra não se alegraram com a volta dos irmãos, que reivindicavam as terras abandonadas por ocasião do exílio. As palavras de Ezequiel, dando esperança aos exilados ao afirmar que o recomeço

\footnotetext{
${ }^{238}$ Cf. H. CAZELLES, História política de Israel, p. 206-210.

${ }^{239}$ Cf. P. SACCHI, Historia del judaísmo en la época del Segundo Templo. Madrid: Trotta, 2004, p. 128-135.

${ }^{240}$ Cf. J. BRIGHT, A História de Israel, p. 487-505.

${ }^{241}$ Cf. J. BRIGHT, A História de Israel, p. 487-505.
} 
aconteceria com eles e não com os que permaneceram na terra, não foram um incentivo ao acolhimento (cf. Ez 33,24). ${ }^{242}$

Outro problema a enfrentar foi com os vizinhos da Samaria que, ao serem afastados das obras de reconstrução do Templo, da qual pretendiam participar, ficaram ressentidos com os retornados. Essa rivalidade entre judeus e samaritanos já era antiga, podendo ser considerada uma briga entre irmãos descendentes de Jacó, José e Judá. O início do estranhamento ocorreu por ocasião da divisão do reino de Salomão e aumentou a partir do século VIII a.C. com a deportação assíria do Reino do Norte. As antigas acusações de apostasias que os Reinos do Norte e do Sul lançavam um contra o outro, tornaram-se realidade quando o povo da Samaria foi deportado e sua terra ocupada por outros povos que não cultuavam YHWH. $^{243}$

Mais tarde, porém, quando a Babilônia atacou Israel (Reino do Sul), um grupo dissidente de sacerdotes de Judá, de mentalidade liberal, fugiu para a Samaria, onde foi recebido hospitaleiramente. Pode até ser que estes sacerdotes tenham fundado uma comunidade religiosa totalmente monoteísta, que se julgava verdadeiramente israelita e guardiã da lei mosaica. É possível que as acusações contra os samaritanos fizessem parte da prática de acusação de crimes chocantes para prejudicar a reputação do oponente, como acontece na política. ${ }^{244}$

Assim, no século VI a.C., quando retornaram do exílio, os sacerdotes de Jerusalém encontraram seus antigos amigos, agora rivais. Judá estava acostumada com as ameaças de povos vizinhos (Iduméia ao sul, Moab e Amon a leste), e na volta do exílio a Samaria se tornara uma rica e poderosa província persa, fazendo com que fosse vista como uma ameaça para Judá. Do ponto de vista sacerdotal, a descendência comum e a mesma fé em YHWH deveriam tornar os samaritanos aliados naturais. O conflito não devia agradar nem a samaritanos nem a judeus, que buscavam a paz e a reconciliação e, talvez por isso, nem todos os sacerdotes de Jerusalém compartilhassem desse antagonismo, que também não devia ser do agrado dos persas. Mesmo assim, os samaritanos continuaram sendo denunciados

\footnotetext{
${ }^{242}$ Cf. T. CRAVEN, "Ezequiel”. In: D. BERGANT; R. J. KARRIS (orgs.), Comentário bíblico, v. 2, p. 67-87; J. BRIGHT, A História de Israel, p. 487-505.

${ }^{243}$ Cf. I. PROVAN; V. P. LONG; T. LONGMMAN III, Uma história bíblica de Israel. São Paulo: Vida Nova, 2003, p. 453-455; M. DOUGLAS, As lágrimas de Jacó, o trabalho sacerdotal de reconciliação, p.19-20.

${ }^{244}$ Cf. M. DOUGLAS, As lágrimas de Jacó, o trabalho sacerdotal de reconciliação, p.19-20.
} 
de praticar idolatria, apostasia e sincretismo religioso (cf. Ne 2,10.19; 3,33-38; $4,2){ }^{245}$

Por causa do afastamento dos samaritanos, as obras de reconstrução do Templo foram embargadas por Sanabalat e Tobias. Provavelmente, estes dois funcionários imaginaram que a nomeação de Neemias fosse prejudicá-los. Tobias tinha sido governador de Amon e era parente de pessoas influentes de Judá, e talvez ele mesmo fosse uma pessoa influente. Sanabalat pode ter sido devoto de YHWH porque os nomes de seus filhos (Delayah e Shelemyah) contêm elementos do nome divino, e parece que Tobias se considerava devoto de YHWH (cf. Ne $6,17-19 ; 13,4-9)$. O desentendimento, provavelmente, foi provocado por pensarem que tinham direito legítimo nas atividades religiosas do Templo. ${ }^{246}$

De fato, os exilados que voltavam se consideravam o verdadeiro Israel e procuravam separar-se tanto dos samaritanos como de seus irmãos judeus menos ortodoxos e de pessoas impuras (cf. Ag 2,10-14). ${ }^{247}$ Os que se fechavam (grande parte da elite do palácio e do Templo) criaram o hábito de chamar os remanescentes de "povo da terra", uma expressão que aludia naturalmente à questão de quem era o legítimo ocupante do território com base em títulos ou genealogia. $^{248}$

Jerusalém tornou-se o centro de uma unidade de todos que habitavam em Judá o que, para alguns, representava sinal dos novos tempos e realização de aspirações passadas (cf. Gn 12,1-3) e de profecias antigas (cf. Is 2,2). O judeu, apenas um dos componentes dessa unidade heterogênea, sentia a abertura ao outro como um perigo para a integridade do grupo, que favorecia os matrimônios mistos, especialmente nas classes dirigentes de sacerdotes sadoquitas, interessadas em unir-se às famílias poderosas de Amon à Samaria. Os matrimônios atendiam aos interesses políticos ajudando a manter o poder sacerdotal em meio a uma situação extremamente instável. ${ }^{249}$

Nesse cenário de disputas estavam incluídas as de cunho material, que ensejaram a criação de "cartas de fundação" míticas sobre títulos de propriedades da "terra" (em conjunto), para serem utilizadas (no campo pessoal), junto com as

\footnotetext{
${ }^{245}$ Cf. M. DOUGLAS, As lágrimas de Jacó, o trabalho sacerdotal de reconciliação, p. 19-20.

${ }^{246}$ Cf. R. J. BURNS, “Esdras e Neemias", p. 319-332.

${ }^{247}$ Cf. J. BRIGHT, A História de Israel, p. 487-505.

${ }^{248}$ Cf. M. LIVERANI, Para além da Bíblia, história antiga de Israel, p. 316-318.

${ }^{249}$ Cf. P. SACCHI, Historia del judaísmo en la época del Segundo Templo, p. 128-135.
} 
genealogias. Assim, tornou-se importante poder fazer referência a tradições que atribuíssem a terra de Canaã às tribos de Israel e que as pessoas pudessem ser identificadas como herdeiros legítimos destas tribos, apartadas das comunidades de remanescentes. $^{250}$

A exclusão se devia não somente a motivos religiosos, mas também econômicos. Sacerdotes de Jerusalém e os proprietários de terra viam nos títulos e na genealogia a única possibilidade de defender seus privilégios (direitos civis). Isso foi motivo de uma interpretação mais rígida da lei, com separação entre judeus e estrangeiros (cf. Dt 7). ${ }^{251}$

Durante o exílio, os que retornavam haviam elaborado uma ideologia de exclusão e pertença e a utilizavam agora para se separar dos judeus que não foram exilados, dos que não emigraram e dos israelitas do norte não exilados, todos javistas, e que, por justiça, deveriam ser considerados os primeiros membros a integrar a nova comunidade. Assim, muitos não foram considerados membros desta nova sociedade. Textos com conteúdo étnico utilizam a expressão "povos da terra", no plural, para indicar as nações excluídas, samaritanos, edomitas, amonitas e todos que ocupassem território que deveria ser dos que retornaram do exílio. A justificativa para a exclusão era a não observância do sábado ou de outras normas javistas, ou a oposição à reconstrução do Templo e à reorganização da sociedade. Com os "povos da terra" (estrangeiros) não se devia contrair matrimônio, pois não reconheciam e não observavam a lei de YHWH. ${ }^{252}$

A reflexão religiosa se desdobrou em uma multiplicidade de correntes teológicas e diferentes tradições que se misturavam e se opunham. ${ }^{253}$ Entre os que queriam participar das obras do Templo, havia dois grupos, o dos retornados, que tiveram o javismo permeado de influências estrangeiras, e o das pessoas que permaneceram na terra após o exílio e que tinham se tornado adeptas do javismo da Samaria. O profeta Ageu atacou estes dois grupos com base em exemplos da lei ritual, em que a pureza cultual não é transferível, mas a impureza cultual é contagiosa, o que se aplicaria a "este povo", pois o lugar onde fossem feitos sacrifícios se tornaria impuro (cf. Ag 2,10-14). Estes grupos foram excluídos das

\footnotetext{
${ }^{250}$ Cf. M. LIVERANI, Para além da Bíblia, história antiga de Israel, p. 316-318.

${ }^{251}$ Cf. P. SACCHI, Historia del judaísmo en la época del Segundo Templo, p. 128-135.

${ }^{252}$ Cf. M. LIVERANI, Para além da Bíblia, história antiga de Israel, p. 316-318.

${ }^{253}$ Cf. R. ALBERTZ, Historia de la religión de Israel em tiempos del Antiguo Testamento. v. 1. Madrid: Trotta, 1999, p. 567-588.
} 
obras do Templo e do culto para não tornar o lugar sagrado impuro. Assim, intensificou-se a tendência à exclusão, que havia sido inaugurada pela teologia deuteronômica. Nem todos aceitaram tal exclusão, principalmente os samaritanos, que tentaram embargar as obras do Templo. ${ }^{254}$

Os judeus da Palestina e da diáspora, que estavam divididos em partidos de natureza intelectual e religiosa, foram dominados pelo partido que aderiu estrita e rigorosamente à lei, sem se permitir concessões a influências nem admitir modificações. Esse partido dominante era formado na maior parte pelos que retornaram da Babilônia, um partido religioso, nacionalista e de esperanças messiânicas. Paralelamente, o partido sacerdotal teocrático se preocupava mais com a expansão da comunidade do que com o rigor da lei. A classe alta de Jerusalém nova, que procurava associar-se com a classe alta da Samaria, era mais aberta ou negligente. ${ }^{255}$ Havia ainda a colônia militar de Elefantina, que há muito se afastara do javismo genuíno com práticas de sincretismo religioso local em contradição com o Deuteronômio (cf. Dt 5,6-8). ${ }^{256}$

Assim, todos estes partidos, independentemente das linhas intelectuais adotadas, tinham consciência da responsabilidade da tarefa religiosa que realizavam de restauração da nova comunidade do povo da aliança e das promessas divinas, que provisoriamente estariam sob o sumo sacerdote, mas que seria substituída um dia pelo reino verdadeiro. Todos se voltaram para essa tarefa com intensa expectativa. ${ }^{257}$

\section{3.}

\section{Constituição sócio-religiosa do povo}

O exílio foi um momento crucial para Israel, sua importância foi tão grande que sua história se divide em pré e pós-exílio. No entanto, os textos

\footnotetext{
${ }^{254}$ Cf. G. FOHRER, História da religião de Israel. Santo André: Academia Cristã; São Paulo: Paulus, 2012, p. 429-433.

${ }^{255}$ Segundo G. N. KNOPPERS (cf. "Parallel Torahs and Inner-Scriptural Interpretation: The Jewish and Samaritan Pentateuchs in Historical Perspective". In: T. B. DOZEMAN, K. SCHMID, B. J. SCHWARTZ (eds.), The Pentateuch International Perspectives on Current Research. TübingenT: Mohr Siebeck, 2011, p. 507-532), os escritos encontrados em Qumran indicam que samaritanos e judeus eram descendentes de um passado comum e, embora discordassem em alguns pontos, o Pentateuco uniu os dois grupos, validando as alegações de ambos com o objetivo de reorganizar a comunidade.

${ }^{256}$ Cf. G. FOHRER, História da religião de Israel, p. 429-433.

${ }^{257}$ Cf. W. EICHRODT, O homem no Antigo Testamento. São Paulo: Metodista, 1965, p. 35-39.
} 
bíblicos tratam essa época de forma muito sucinta. O pouco material escrito pode refletir o trauma do momento e questões sociais (dissolução dos Estados e instituições, ausência de escribas), materiais (a falta de recursos obrigava a se ocupar somente com a sobrevivência), ou psicológicas (depressão, desânimo, falta de perspectiva futura).

A história de Israel, agora dominado, deu lugar a uma nova vida que requeria adaptação e integração como forma de sobrevivência. $\mathrm{O}$ homem do Antigo Testamento considera a vida de maneira positiva e a existência um dom divino, como parte de um plano que YHWH revela ao seu povo. Este plano inclui a família, a terra e o povo, elementos que dependem igualmente de YHWH e que condicionam a vida como dom divino. Se faltar alguns desses elementos essenciais, o israelita deixa de existir. ${ }^{258}$

Assim, apesar de exilado, precisava viver e não morrer, consciente de que viver isolado não seria viver plenamente. "A vida pedia que houvesse pelo menos um vizinho, um amigo, para guiar e estar ao redor e, depois da morte, fazer memória do seu nome" (cf. Sl 41). ${ }^{259}$ Ao escolher um caminho que tornasse a vida uma realidade (cf. Pr 13,14), ${ }^{260}$ viveu novos relacionamentos, embora os sentimentos adversos permanecessem como forma de manter a esperança (cf. Sl 137,4-6), e as aflições com a inimizade servissem para gerar resiliência (cf. S1 $137,7-9){ }^{261}$

Só se percebe o conceito de pessoa na esfera social do indivíduo. O homem no antigo Israel atua em diferentes papéis (individuais e sociais) como homem e mulher, pais e filhos, amigos e inimigos, senhores e servos, sacerdotes e comunidade religiosa. O judeu valorizava a vida comunitária, assim, no exílio, procurou viver, amar, superar o ódio e manter-se vivo, integrando-se em “constelações" básicas, mantendo a fé em YHWH. ${ }^{262}$

Foi necessário, portanto, integrar-se após sucessivas deportações, iniciadas a partir da metade do século VIII a.C., quando entrou no campo de forças de

\footnotetext{
${ }^{258}$ Cf. R. MARTIN-ACHARD, Da morte à ressurreição segundo o Antigo Testamento, p. 19-31.

${ }^{259}$ Cf. B. JANOWSKI, "Der Mensch im alten Israel - Grundfragen alttestamenthcher Anthropologie". In: ZThK 102 (2005), p. 143-175.

${ }^{260}$ Cf. L. E. BOADT, "Provérbios". In: D. BERGANT; R. J. KARRIS, Comentário bíblico, v. 1, p. 235-259.

${ }^{261}$ Cf. R. J. CLIFFORD, “Salmos”. In: D. BERGANT; R. J. KARRIS, Comentário bíblico, v. 1, p. $185-211$

${ }^{262}$ Cf. B. JANOWSKI, "Der Mensch im alten Israel - Grundfragen alttestamenthcher Anthropologie", p. 143-175.
} 
grandes potências dominadoras do Oriente (cf. 2Rs 15,29). Não é verdadeira a informação de que a terra permaneceu deserta por setenta anos, principalmente porque parte da população ficou na terra e parte foi exilada (cf. $2 \mathrm{Cr} 36,20-21$; 2Rs $25,11-12){ }^{263}$

As deportações assírias, com ideologia destrutiva, visavam a eliminar as identidades dos dominados com deportações cruzadas. O objetivo era criar uma nova sociedade, mista, com dominados de diversas origens. Eliminava-se com isso a resistência política, mas salvaguardava-se a economia. A língua aramaica foi assimilada e a religião resultou em difuso sincretismo, persistindo o culto cananeu e o javismo, revisado, e que soou inaceitável aos sobreviventes do sul (cf. 2Rs 17,29-31).

Após as deportações assírias, os assentamentos com as trocas cruzadas de populações cresceram e prosperaram em torno de Jerusalém, com as vilas agrícolas na planície de Judá que produziam vinho e óleo de oliva, parecendo ter superado rapidamente a grande devastação assíria. ${ }^{264}$

A queda do Reino do Sul, talvez em função da destruição que se seguiu, provocou grave crise demográfica e cultural, uma ruína atestada arqueologicamente. Sumiram do cenário dois terços dos sítios com assentamentos e os que sobreviveram tiveram uma redução de um terço de sua superfície, a população foi reduzida entre $85 \%$ e $90 \%$, a produção artesanal de qualidade despareceu e o uso de escrita se tornou raro. Este é o cenário em que os exilados que não morreram durante a deportação buscavam sobreviver. Judá, que fora o centro organizacional da administração e do culto, com sua destruição se tornou uma região de vilas pobres, com poucos recursos, de camponeses. Os espaços deixados vazios foram ocupados pelos vizinhos mais preparados para uma retomada. Com suas estratégias de controle e exploração, tanto assírios como babilônios quebraram o crescimento demográfico, a utilização do território, a originalidade criativa e a cultura geral de Israel e de outros povos. Embora não haja vastas documentações, sabe-se que, a exemplo de outros acontecimentos semelhantes de conquistas forçadas e mistura étnica, onde os debates ideológicos são banidos, os "restos" das populações dominadas passaram por profundo processo de perda cultural. Os livros de história tradicionais não conseguem

\footnotetext{
${ }^{263}$ Cf. R. KESSLER, História Social do antigo Israel. São Paulo: Paulinas, 2009, p. 153-167.

${ }^{264}$ Cf. M. LIVERANI, Para além da Bíblia, história antiga de Israel, p. 191-249.
} 
visualizar adequadamente a imagem de uma nação (norte e sul de Israel) precipitando-se abaixo em nível demográfico e cultural, marcando o fim de uma época. ${ }^{265}$

A região que os exilados foram obrigados a abandonar, apesar de perder as lideranças intelectuais e políticas e da situação de opressão econômica, não se transformou em deserto, sem população, como se poderia pensar (cf. Lm 5,4s). O exílio não foi uma situação de miséria, escravidão e opressão. Sem dúvida havia sofrimento, mas eram sentimentos internos que não impediam a vida de continuar (cf. S1 137,1). Alguns levavam uma vida razoavelmente confortável como súditos reassentados à força, mas não escravos. Podiam deslocar-se, construir suas casas, cultivar suas plantações e praticar o comércio (cf. Jr 29). ${ }^{266}$

Com o exílio, a estrutura da família, com seu quadro de relações de parentesco, se modificou. Primeiro, as famílias foram parcialmente separadas nas deportações (cf. Ez 24,21). Segundo, possivelmente os exilados se estabeleciam em algum espaço permitido como arrendatários e não como proprietários e, com isso, a herança, fundamento da instituição de parentesco deixa de existir (cf. Dt 19,14; 1Rs 21,3; Mq 2,2). Terceiro, nos lugares onde os exilados se assentaram, assentaram-se também membros de diferentes famílias que não tinham laços de parentesco entre si. $^{267}$

Notícias da colônia militar judaica de Elefantina faz supor um quadro de deportação mais amplo, voluntária, ao invés das violentas da Babilônia. Esta colônia já existia desde antes da conquista do Egito por Cambises, em 525 a.C. e nela havia um Templo onde se adorava YHWH ao lado das divindades AschmBethel e Anat-Bethel. A carta de Aristeas, parágrafo 13, fala de uma batalha em que tropas judaicas lutaram no tempo do faraó Psamético I (664-610 a.C.) ou Psamético II (595-589 a.C.) contra o rei dos etíopes, fazendo supor uma imigração gradual, ainda no período tardio da monarquia. Os que foram exilados para a Babilônia pretendiam voltar, os que emigraram para o Egito, ali construíram suas vidas e consideram esta nação sua nova pátria, embora procurassem manter sua identidade judaica (cf. Jr 44,1). ${ }^{268}$

\footnotetext{
${ }^{265}$ Cf. M. LIVERANI, Para além da Bíblia, história antiga de Israel, p. 191-249.

${ }^{266} \mathrm{Cf}$. H. DONNER, História de Israel e dos povos, p. 435-439.

${ }^{267}$ Cf. R. KESSLER, História Social do antigo Israel, p.153-167.

${ }^{268}$ Cf. R. KESSLER, História Social do antigo Israel, p. 153-167.
} 
O quadro de deportações favorece a ideia de uma descontinuidade étnica. Os descendentes dos que tiveram que deixar a terra com as deportações se encontraram para reorganizar a comunidade e reconstruir o Templo. Eram descendentes que preservaram a consciência de serem legítimos herdeiros (talvez únicos) das tradições israelitas e judaicas, e os da terra, membros das antigas camadas inferiores, e uma nova elite que se desenvolveu durante o exílio, composta de elementos não judaicos. O profeta Zacarias parece se identificar como legítimo herdeiro de Israel, recebendo a prata e o ouro, que deveriam ser tomados dos exilados, necessários à confecção de uma coroa (cf. Zc 6,9-15).

O retorno deu origem ao conflito pela terra e pela condução da política e da religião, o que obriga o leitor a levar em conta a oposição ideológica desse conflito. O entendimento do significado da mulher no efá em Zc 5,5-11, principalmente em relação à mulher sentada no efá, só pode ser entendido com um olhar crítico à formação bastante diversificada dos grupos do retorno em relação à cultura, à religião e aos interesses particulares para quem Zacarias profetiza. ${ }^{269}$

\section{4.}

\section{A mulher no contexto sócio-religioso}

Os textos bíblicos são importantes documentos para se compreender o "papel social" da mulher durante o obscuro domínio persa. Em qualquer sociedade, homens e mulheres desempenham papéis sociais que revelam o perfil de cada época e lugar. A vida em grupo pressupõe expectativas de comportamento entre indivíduos, na família e no trabalho, e num momento de mudança e transformação social, pode-se supor que tenha havido prejuízo para a mulher. Como atuava a mulher numa sociedade que tentava se reorganizar e criar uma nova identidade?

A figura da mulher do antigo Israel estava associada ao pecado (Gn 3), o que a tornou símbolo da corrupção, e à ideia de fragilidade, que a colocou em situação de total dependência do homem num sistema patriarcal. Este modelo sugere a tutela constante da mulher ao longo de sua vida pelo homem: primeiro

${ }^{269}$ Cf. R. ALBERTZ, Historia de la religión de Israel em tiempos del Antiguo Testamento, p. 567-588. 
pelo pai, eventualmente pelo irmão, e depois pelo marido, simbolizado pelo contrato do casamento. Mas, terá a mulher da comunidade judaica do pós-exílio seguido fielmente esse modelo? Se a feminilidade ou masculinidade, no sentido de comportamento e identidade, são uma construção cultural, fruto de cada época, é possível que a mulher tenha assumido outros papéis, resultado do enfrentamento e posicionamento diante de novas situações e desafiadoras circunstâncias. $^{270}$

Os problemas provocados pelo envio do povo de Israel para outras terras e de outros povos para Judá, durante os exílios a que foram submetidos, não terminaram com o retorno da Babilônia. Primeiro, tiveram que enfrentar a realidade de que nem todos na província de Judá eram judeus e nem todos os judeus retornaram da diáspora. Segundo, precisaram resolver a questão da posse das terras, cobradas pelos que retornaram e alegavam serem os titulares das propriedades ocupadas pelos remanescentes. Finalmente, precisaram enfrentar duas questões que afetaram diretamente a mulher da comunidade judaica: a) miséria e endividamento da população, o que tornava filhos e filhas escravos, trazendo consequências nefastas para a vida familiar; b) transformações estruturais das famílias, que após dois exílios tinham vivido "no meio das nações", e agora buscavam, através do mecanismo das listas genealógicas e da proibição de casamentos mistos (Esd 10,11; Ne 10,31), uma identificação de pertença à "casa de Israel". O resultado foi um corpus legislativo, concebido parte na realidade e parte no imaginário, projetado com base na aliança entre YHWH e o povo através de um olhar retroativo, para que, com base na Torah, Israel recebesse uma identidade. ${ }^{271}$

Todos estes fatores influenciaram o papel da mulher na sociedade judaica provincial no período persa. É provável que o modelo de comportamento da mulher de uma comunidade estável e circunscrita a um só povo antes do exílio, e depois dispersa e misturada a estrangeiros, não atendia à nova comunidade que buscava reorganizar-se, sendo obrigada a ajustar-se às novas condições. Atualizações podem ser observadas nas narrativas bíblicas da época, conforme

\footnotetext{
${ }^{270}$ Cf. T. C. ESKENAZI, "Out From the Shadows Biblical Women in the Postexilic Era". In: JSOT 54 (1992), p. 23-43.

${ }^{271}$ Cf. R. ALBERTZ, Historia de la religión de Israel em tiempos del Antiguo Testamento, p. 567-588; M. LIVERANI, Para além da Bíblia, história antiga de Israel, p. 309-318.413-434; R. KESSLER, História social do antigo Israel, p. 173-184; E. S. GERSTEMBERGER, Israel no tempo dos persas, p. 114-128.
} 
abaixo, nas leis, nas relações familiares e de trabalho, na regularização de bens e propriedades subjacente à discussão dos matrimônios mistos.

A mulher e a lei (Torah)

A lei de Israel, um conjunto de regras que ordenam as relações do homem com YHWH e dos homens entre si, é considerada revelação divina. A noção de revelação divina abriu novas possibilidades intelectuais e sociais, mas apresentou dificuldades para mudanças. Como revisar textos legais e adaptá-los às novas circunstâncias, sem comprometer a autoridade divina? ${ }^{272}$

Os que retornavam do exílio da Babilônia queriam manter os vínculos com o passado, e também preparar um futuro para todo o povo, segundo as promessas divinas feitas aos patriarcas, revivendo o êxodo e observando a Lei de Moisés, em conformidade com as antigas tradições, (cf. Ex 19,9-20-20,1-21). ${ }^{273}$ Reconciliar diferentes pontos de vista e harmonizar relatos e leis, significava reconciliar os resultados de diferentes grupos: a) grandes proprietários de terra em Judá; b) famílias sacerdotais de Jerusalém; c) grupos independentes, aculturados e economicamente poderosos; d) os que ficaram na terra. ${ }^{274}$

Relatos, leis e até poemas uniram-se em um conjunto harmônico (o Pentateuco) como um documento plural, no qual o sistema jurídico estava quase totalmente em mãos masculinas e os textos eram dirigidos aos homens, sujeitos do direito. $^{275}$ Algumas narrativas bíblicas, contudo, revelam que havia uma práxis diferente baseada no direito consuetudinário e nos costumes do "povo da terra", evidenciando que havia um movimento que, se não era "pró-mulher", também não era essencialmente masculino e exclusivista. ${ }^{276}$ Sem esquecer que as mulheres de Israel eram também mães, esposas, irmãs e filhas, ao lado dos homens e fazendo parte de suas vidas, razão pela qual também tinham direito aos bens familiares (cf. $\mathrm{Nm} 27,1-11 ; 36,1-12)$.

\footnotetext{
${ }^{272}$ Cf. B. M. LEVINSON, Revisão legal e renovação religiosa no antigo Israel. São Paulo: Paulus, 2008, p. 41-61.

${ }^{273}$ Cf. B. M. LEVINSON, Revisão legal e renovação religiosa no antigo Israel, p. 41-61.

${ }^{274}$ Cf. J.-L. SKA, O canteiro do Pentateuco: problemas de composição e de interpretação, aspectos literários e teológicos. São Paulo: Paulinas, 2016, p. 226-234.

${ }^{275}$ Cf. J.-L. SKA, O canteiro do Pentateuco, p. 113-114.123-124.184-188; H. DONNER, História de Israel e dos povos vizinhos, p. 446; F. CRÜSEMANN, A Torá, p. 347-352; B. M. LEVINSON, Revisão legal e renovação religiosa no antigo Israel, p. 41-61.

${ }^{276}$ Cf. J.-L. SKA, O canteiro do Pentateuco, p. 206.
} 
A situação social da mulher pode ser constatada nos relatos bíblicos do AT que mostram que não se encontra excluída de seus direitos, apenas não é citada sempre de forma explícita, ${ }^{277}$ como acontece com as normas jurídicas atuais. ${ }^{278}$ Oculta nas expressões masculinas dos textos bíblicos, a posição jurídica da mulher é pressupostamente abrangida pela "linguagem inclusiva" das prescrições legais conforme a seguir: ${ }^{279}$

a) na lei que determina guardar o sábado: "não farás nenhum trabalho, nem tu, nem teu filho, nem tua filha, nem teu escravo, nem tua escrava, nem teu animal, nem o estrangeiro que está em tuas portas" (cf. Ex 20,8); se a filha e a escrava estão incluídas, inclui-se implicitamente a esposa do trabalhador e do estrangeiro; ${ }^{280}$

b) na lei para guardar o sábado: “descansarás no sétimo dia, para que descanse o teu boi e o teu jumento, e tome alento o filho da tua serva e o estrangeiro" (cf. Ex 23,12); se até os animais, o filho da serva e o estrangeiro estão incluídos, inclui-se implicitamente a mulher, a vaca, a jumenta, a filha da serva, a serva e a estrangeira; ${ }^{281}$

c) na permissão para participar de festas anuais e dos sacrifícios: "tu, teu filho e tua filha, teu servo e tua serva, o levita e o estrangeiro, o órfão e a

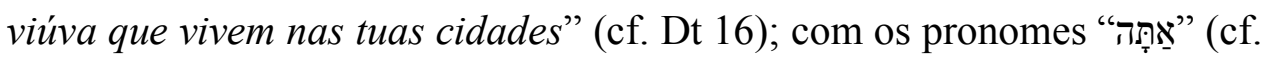

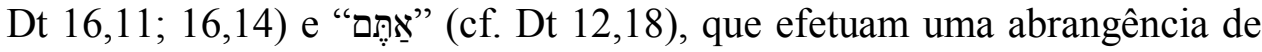
gênero e ampliam o alcance das prescrições do Deuteronômio, "elas" são sempre pressupostas e abrangidas pela linguagem inclusiva dos textos legais e cultuais". ${ }^{282}$

Não somente em "linguagem inclusiva", os direitos e deveres da mulher aparecem em textos legais. Há casos mais complexos de declarações legais

\footnotetext{
277 Cf. F. CRÜSEMANN, A Torá, p. 347-352.

${ }^{278}$ Em português, na regra gramatical para o plural de dois gêneros, a concordância é feita com o gênero masculino, sem que isso implique exclusão da mulher ou evidência de misoginia.

${ }^{279} \mathrm{O}$ problema de se entender a posição jurídica das mulheres nos textos bíblicos é que as expressões masculinas excluem as mulheres em termos linguísticos, e as incluem em termos de conteúdo, o que se pode chamar de "linguagem inclusiva" (cf. F. CRÜSEMANN, F., A Torá, p. 348-350).

${ }^{280}$ Cf. R. L. SMITH, Teologia do Antigo Testamento. São Paulo: Vida Nova, 2001, p. 242.

${ }^{281}$ Cf. J. F. CRAGHAN, "Êxodo". In: D. BERGANT; R. J. KARRIS, R. J. (Orgs.), Comentário bíblico, v. 1, p. 91-120.

${ }^{282}$ Cf. F. CRÜSEMANN, A Torá, p. 350-352.
} 
masculinas que necessitam de análise mais detalhada para constatar que afetam a mulher. Isso ocorre, por exemplo, nos casos de "homicídios" (cf. Ex 21,12-17) com a prescrição que o encabeça: "quem ferir 'homem' e causar a sua morte, será morto" (cf. Ex 21,12). Embora em formulação masculina, esta lei inclui prescrições sobre "golpe e ferimentos" (cf. Ex 21,18-36), do qual faz parte um acidente que poderia ocorrer num litígio entre dois homens, em que uma mulher grávida poderia ser derrubada provocando o nascimento da criança (cf. Ex 21,22$25),{ }^{283}$ ou seja, em caso de mulher ferida de morte se fará cumprir a lei de talião (cf. Êx 21,22-25). ${ }^{284}$

Em casos de "restituição" por ofensa a YHWH no seu direito sagrado, a lei explicita sua validade para "um homem ou mulher" (cf. Nm 5,5), mas sobre a restituição do prejuízo, apesar de não especificar a mulher, a inclui (cf. Nm 5,8). Há casos explícitos sobre questões religiosas e cultuais, como "desvio do culto", em que a mulher é cobrada ao lado do homem pela transgressão da Aliança, servindo a outros deuses (cf. Dt 17,2), ou "contra seduções da idolatria", em que é mencionada ao lado do irmão, filho e filha e amigo (cf. Dt 13,7). ${ }^{285}$

Investigações arqueológicas também evidenciam que a mulher tinha possibilidade de exercer, plena e pessoalmente, atos da vida civil na sociedade, por exemplo, com o selo de uma mulher encontrado com a inscrição "Shelomit 'amat de Elnatã, o governador" da época persa, sem datação exata. Provavelmente a mesma Shelomit, citada em 1Cr 3,19 como filha de Zorobabel. Junto com o selo, foram encontradas bulas, entre as quais uma com o nome de Shelomit e outras com o nome da província de Judá. Assim, imagina-se que a mulher agia com poderes legais para firmar acordos ou servir de testemunha. ${ }^{286}$

\section{Revisão das prescrições legais}

No antigo Israel, a mulher podia buscar seus direitos junto aos anciãos que decidiam as disputas e processos nos portões das cidades. Estes anciãos eram

\footnotetext{
${ }^{283}$ Cf. L. A. FERNANDES, "Aborto justificado? O equívoco da leitura e da interpretação espúria de Ex 21,22-25; Nm 5,11-31; Sl 139,16”. In: Vox Scripturae XXVI/3 (2018), p. 439-461.

${ }^{284}$ Cf. F. CRÜSEMANN, A Torá, p. 349-350-351.

${ }^{285}$ Cf. F. CRÜSEMANN, A Torá, p. 349-350-351.

${ }^{286}$ Cf. R. KESSLER, História social do Antigo Israel, p. 175. Segundo F. CRÜSEMANN (A Torá, p. 351), a identificação no sinete como filha ou esposa não exclui a autonomia jurídica da mulher.
} 
chefes das famílias dos clãs, os notáveis do lugar, que usavam de sua autoridade para o cumprimento da lei. Um exemplo, é a lei do levirato (levir, latim para “cunhado") que determinava que o cunhado da mulher viúva deveria tomá-la para que gerasse filhos, que levariam o nome do falecido adiante e herdariam seus bens (cf. Dt 25,5-6). O objetivo era manter a riqueza na família, um desejo do sistema patriarcal. O cunhado poderia recusar, deixando implícito que desejava herdar os bens do irmão em vez de transmiti-los ao "filho" do falecido (cf. Nm 27,9). A viúva, em reação, tirar-lhe-ia a sandália do pé e cuspir-lhe-ia no rosto e declararia diante de todos: "É isso que se deve fazer a um homem que não edifica a casa do seu irmão", e em Israel todos o chamariam pelo apelido de "casa do descalçado" (cf. Dt 25,7-10; Rt 3,12-13; 4,1-11).

Outro exemplo de conflito, que a mulher podia levar aos portões da cidade, é a lei que dá ao homem o direito de repudiar a esposa. A lei apenas tratava o divórcio como um costume aceito na comunidade. Parece que a intenção ao proibir o homem de voltar a casar-se com a ex-mulher, caso ela houvesse se casado de novo e o novo marido também tivesse se divorciado dela, era com os divórcios seguidos que poderiam tornar-se uma forma de legal de adultério (cf. Dt 24,1-4). ${ }^{287}$

Numa época em que a virgindade era grandemente valorizada, e podia haver acusações falsas contra uma jovem, a lei limitava o direito do homem (cf. Dt 22,13-21). Embora nesta lei a mulher não pudesse exercer algum papel no tribunal, na defesa de seu futuro, o legislador demonstra preocupação por seus direitos diante de falsas acusações, e quebra o poder do marido sobre a esposa, com o direito de a família proteger a jovem, punindo o marido com pena severa e desonra. ${ }^{288}$

Nem todos os casos foram levados aos portões da cidade, como o de Tamar, a canaanita, por exemplo, que fez cumprir seus direitos de forma peculiar. Ela ignorou seu direito de levar o descumprimento da lei aos anciãos (cf. Dt 25,5-10) e agiu com independência para encontrar uma solução para seu futuro (cf. Gn 38,1-27). Viúva de um filho de Judá, o sogro falhou em fazer seus filhos cumprirem a lei. Tamar, então, criou uma artimanha e engravidou do sogro, justamente ele que tinha jurisdição sobre o caso. Na situação de viúva, sua

\footnotetext{
${ }^{287}$ L. J. HOPPE, “Deuteronômio”, Comentário bíblico, v.1, p.187-213.

${ }^{288}$ Cf. F. CRÜSEMANN, A Torá, p. 355-356.
} 
gravidez seria considerada adultério, sujeita à pena de morte, porque, pela lei do levirato, estaria noiva de outro filho de Judá. Ao ser identificado como pai da criança que Tamar espera, Judá admite sua culpa por não cumprir a lei. ${ }^{289}$

Certamente as divergências entre lei e costumes fizeram os legisladores sentirem a necessidade de revisão e atualização das prescrições legais e o fizeram de forma consistente, criativa e harmoniosa, para atender às demandas da sociedade. Contudo, nem todas as questões foram atualizadas através da lei. É provável que o processo de análise e reflexão, para uma decisão de colocar os valores de uma sociedade em transformação, tenha provocado muitos conflitos e tensões, e que, em alguns momentos foi preferível fazer isso através de narrativas bíblicas, que preencheriam lacunas e atenderiam a uma nova ordem jurídica, conforme os relatos a seguir. ${ }^{290}$

\section{Lei e direito}

\section{a. Moisés e o direito à vida}

O nascimento de Moisés é um relato inteiro de confronto com o direito. Os egípcios consideravam que o rei era divino, mas cinco mulheres ignoram o poder opressor de um rei que tenta intervir no projeto de YHWH, de numerosa descendência para Israel. ${ }^{291}$ Duas parteiras, com acesso direto ao faraó, Sefra e Fua, são orientadas a eliminar os meninos que nascessem dos hebreus (cf. Ex 1,15-21). O convite do faraó era uma ordem, contudo, com coragem civil, as parteiras agem com a lógica de YHWH, Senhor da história (cf. Gn 14,19) e desobedecem ao plano cruel. ${ }^{292}$ A desobediência ao faraó vai contra toda a expectativa da relação que deveria haver entre mulheres simples do povo e o poder (cf. Ex 1,15-22). No confronto com as parteiras, o faraó pede conta das suas recomendações. As parteiras respondem que as mulheres hebreias eram cheias de vida e elas chegavam tarde demais.

A argumentação para a desobediência é baseada na mentira, pois o momento

\footnotetext{
${ }^{289}$ Cf. Gn 38, 6-26; cf. também Lv 20,10; Dt 22,22.

${ }^{290}$ Cf. F. CRÜSEMANN, A Torá, p. 420-425; J.-L SKA, O canteiro do Pentateuco, p. 234-236;

B. M. LEVINSON, Revisão legal e renovação religiosa no antigo Israel, p. 43-70.

${ }^{291}$ Cf. J. F. CRAGHAN, "Êxodo”, p. 91-120.

292 Cf. A. VILLAS BOAS, M. GRENZER, "A resistência das parteiras, (Ex 1,15-22): especificidades de uma teologia literário-narrativa”, ER 290/1 (2015), p. 129-152.
} 
do parto é quando a mulher mais precisa de auxílio de uma parteira (cf. Ex 1,1819; Gn 35,17; 38,28). A desobediência é provocada pelo temor a YHWH (cf. Ex $1,17$; $\operatorname{Pr} 16,6 ; 29,25)$, temor que protege a descendência de Israel e torna mais humanas as relações (cf. Gn 20,11; 42,18,18; Lv 19,14). "O não fazer das parteiras, corresponde ao fazer de YHWH" (cf. Ex 1,17.21). ${ }^{293}$ Com ousadia, o redator final mostra que o poder de YHWH é maior que o poder estabelecido, e o demonstra através destas mulheres.

Assim, nasceu Moisés, e a mulher que deu à luz não pode mais escondê-lo e, então, coloca-o num cesto à beira do rio (cf. Ex 2,1-3). A filha do faraó se compadece e recolhe o menino (cf. Ex 2,6). A irmã de Moisés indica a própria mãe para amamentá-lo e criá-lo (cf. Ex 2,4.8-9), e a mãe adotiva de Moisés, a filha do faraó, o recebe de volta já crescido (cf. Ex 2,10). Vê-se que o grande líder foi salvo pela ação de mulheres.

Neste relato, se observa que a Bíblia conhece a distinção entre "lei" e "direito", 294 quando as parteiras desobedecem ao faraó, representante do poder legítimo, e, em nome de um princípio maior, que é o temor a YHWH, elas privilegiam o direito à vida. ${ }^{295} \mathrm{Na}$ estratégia da narrativa do nascimento de Moisés foi escolhida como participante a filha do faraó, que desobedece ao decreto injusto promulgado pelo pai. Ela atende à voz da natureza humana e desrespeita a lei (cf. Ex 2,5-6). Da mesma forma, a mãe de Moisés, por motivos mais justos, desrespeitou a lei, correndo o risco de ser punida pelo faraó (cf. Ex $2,1-4)$.

\section{b. Sansão e a lei do nazireato}

A vida desenfreada de Sansão e sua relutância em abraçar o chamado de YHWH (cf. Jz 13,1-16,31) estão relacionadas com a própria história de Israel e sua luta íntima para se manter separado das outras nações por causa da aliança. Assim, este personagem é posto separado dos homens comuns por causa de seu chamado como nazireu. Sansão, o herói, é forte como gigante e fraco como criança, fascina as mulheres e é enganado por elas, põe em apuros os filisteus,

293 Cf. A. VILLAS BOAS; M. GRENZER, "A resistência das parteiras, (Ex 1,15-22): especificidades de uma teologia literário-narrativa", p. 129-152.

${ }^{294}$ Cf. J.-L SKA, O canteiro do Pentateuco, p. 123-134.

295 Cf. J.-L. SKA, O canteiro do Pentateuco, p. 123-134. 
mas não liberta a região de seu domínio. ${ }^{296}$

O relato mostra a transgressão ao determinado pela lei do voto do nazireato, no qual o nazir, adulto, de livre e espontânea vontade, se consagra a YHWH pela vida toda ou por determinado período (cf. Nm 6,1-8). Sansão é consagrado nazir desde a concepção, que se deu por intervenção divina (sua mãe era estéril), devendo viver sob os regulamentos do nazireato até a morte: abster-se de bebidas alcoólicas, não rapar a cabeça e evitar qualquer contato com mortos (cf. Jz 13,1 16,31). Entretanto, quebra o voto várias vezes: ao comer o mel, impuro porque foi tirado de um cadáver (cf. Jz 14,8-9); ao tocar a carcaça de um animal (cf. Jz 15,15-17); ao deixar-se amarrar por Dalila com sete cordas de arco frescas, feitas de tendões de animais abatidos (cf. Jz 16,7-9); e ao rapar a cabeça (cf. Jz 16,19). A morte de Sansão é uma revisão legal para provar que a lei deve ser cumprida e ao mesmo tempo mostrar, que apesar de seu egoísmo, por ter voltado para YHWH (cf. Jz 16,28) teve morte honrosa (cf. Jz 16,31). ${ }^{297}$

\section{c. Rute e a lei do levirato}

O Livro de Rute, com temas como a fome, o exílio e o retorno, é sobre duas mulheres que agem por iniciativa própria e fé, numa sociedade dominada por homens. É também um desafio à lei de proibição aos casamentos mistos (cf. Dt 23,4; Esd 10,11). ${ }^{298}$ Como uma história jurídica ${ }^{299}$ romantizada, esforça-se em modificar a lei sobre a questão étnica e religiosa de forma significativa para a identidade da comunidade judaica. ${ }^{300}$ A narrativa pode ter sido um protesto contra a determinação de Esdras e Neemias para que os judeus se separassem de esposas estrangeiras, ${ }^{301}$ quando Esdras tentava dar uma identidade à comunidade

\footnotetext{
${ }^{296}$ Cf. B. G. WEBB, “Juízes”. In: D. A. CARSON; R. T. FRANCE; J. A. MOTYER; G. J. WENHAM (orgs.), Comentário bíblico Vida Nova. São Paulo: Vida Nova, 2009, p. 399-437.

${ }^{297}$ Cf. J. A. GRINDEL, “Juízes”. In: Comentário bíblico, v. 1, p. 233-246.

${ }^{298}$ Cf. B. M. LEVINSON, Revisão legal e renovação religiosa no antigo Israel, p. 52-61; J.-L. SKA, O canteiro do Pentateuco, p. 194-200.

${ }^{299}$ Segundo B. M. LEVINSON (Revisão legal e renovação religiosa no antigo Israel, p. 52-61), o Livro de Rute depende das leis, como as regras da colheita (cf. Dt 24,19), e a partir delas, interpreta, revisa e liberaliza antigas exigências: exclusão dos moabitas da comunidade (cf. Dt 23,4-5; Rt 4,11) e lei do matrimônio levirático (cf. Dt 25,5-10; Rt 4,5).

${ }^{300}$ Cf. B. M. LEVINSON, Revisão legal e renovação religiosa no antigo Israel, p. 52-61; J.-L. SKA, O canteiro do Pentateuco, p. 194-200.

${ }^{301}$ Cf. J. BALDWIN, "Rute". In: D. A. CARSON; R. T. FRANCE; J. A. MOTYER; G. J. WENHAM (orgs.), Comentário bíblico Vida Nova. São Paulo: Vida Nova, 2009, p. 438-450. Segundo L. MORRIS ("Rute". In: Juízes e Rute, introdução e comentário. São Paulo: Vida Nova, 1968, p. 205-301), a datação do Livro de Rute é fruto de grande debate, a questão
} 
judaica com a proibição de casamentos mistos (cf. Esd 9-10). A continuidade dos propósitos de YHWH através da genealogia é mostrada, de forma extraordinária, do casamento de Booz e Rute até ao nascimento do rei Davi, fundador de uma dinastia monárquica (cf. Rt 4,17-22). ${ }^{302}$ Assim, a compreensão do status legal e religioso dos estrangeiros, da etnicidade e dos casamentos mistos torna-se bastante diferente da pretendida por Esdras e Neemias. ${ }^{303}$

A história de Rute é paradoxal e paradigmática, pois ela é moabita, pobre e viúva, mas não abandonou sua sogra, sendo considerada "melhor que sete filhos" (cf. Rt 4,15), um elogio de grande significado no mundo do antigo Israel. Ela é comparável à descrição da mulher virtuosa de Provérbios: não come pão no ócio (cf. Pv 31,27); com seus esforços busca alimento para si e para a sogra (cf. Pv 31,15); é digna de se tornar esposa do rei (cf. Pv 31,1). A palavra chave da história de Rute é "bondade" (గֶ) (cf. Rt 1,8; 2,20; 3,10).

Contudo, o Livro de Rute não é apenas uma história de vida virtuosa e exemplar, isso seria desconsiderar o caráter de Noemi, a judia, e não dar importância ao papel de $\mathrm{YHWH}$, não tão manifesto na narrativa, mas cuja atividade por trás dos acontecimentos é mostrada a Noemi pelas mulheres de Belém. ${ }^{305}$ A genealogia de Mateus, ao mencionar Rute (cf. Mt 1,5), fará refletir que "a mão de Deus cobre a história toda, executando seu propósito, geração após geração". ${ }^{306}$ Da mesma forma, a genealogia contida no final do livro de Rute (cf. Rt 4,18-22) faz "uma ponte sobre o rio do esquecimento que liga a margem de hoje à margem do anteontem" construindo "pontes quando o rio do esquecimento chega a separar o hoje do ontem e do anteontem, ou seja, quando não é mais

permanece em aberto, embora ele se posicione contra uma datação no pós-exílio, atualmente aceita pela maioria; para J. A. FISCHER ("Rute". In: D. BERGANT; R. J. KARRIS (orgs.), Comentário bíblico, v. 1, p. 261-266) a data é pós-exílica, séc. V a.C.; para E. C. MELERO ("Rute". In: S. G. OPORTO; M. S. GARCÍA (orgs.), Comentário ao Antigo Testamento II. São Paulo: Ave Maria, 1997, p. 619-628); a data é mais recente ainda, com redação final entre os sécs. IV-III a.C.

302 J. A. FISCHER ("Rute", p. 261-266) lembra que Rute é incluída na genealogia de Jesus por Mateus, em Mt 1,5, mas não é incluída na genealogia correspondente no primeiro livro de Crônicas, em $1 \mathrm{Cr} 2$.

${ }^{303}$ Cf. B. M. LEVINSON, Revisão legal e renovação religiosa no antigo Israel, p. 52-61; L. MORRIS, Juízes e Rute, p. 229-301; J.-L. SKA, O canteiro do Pentateuco, p. 195-200.

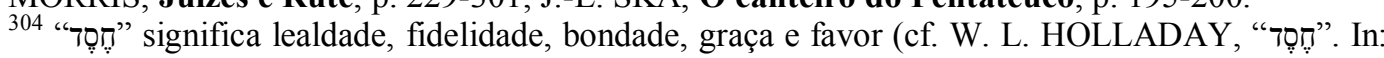
LHAAT, p. 157).

${ }^{305}$ Cf. A. S. VIEGAS, Uma heroína chamada Rute: análise narrativa e intertextual de Rt 3. Rio de Janeiro, Tese Doutorado - Departamento de Teologia, Pontifícia Universidade Católica do Rio de Janeiro (2017), p. 19-23.

${ }^{306}$ Cf. L. MORRIS, Juízes e Rute, p. 301. 
possível alcançar as margens dos próprios antepassados". 307

\section{d. Resfa e o direito de enterrar os mortos}

Resfa é o relato de uma mulher em defesa do direito de enterrar seus filhos e do enfrentamento do poder representado pelos homens. Saul, esposo de Resfa, transgride a aliança com os guibeonitas massacrando-os (cf. Js 9,3-27), e YHWH exige o reparo do mal praticado. Os guibeonitas sobreviventes decidem os meios de expiação, e Davi escolhe dois filhos e cinco netos de Saul para serem executados. Entre os executados estavam dois filhos que Resfa dera a Saul.

Os corpos dos mortos devem ficar expostos às aves do céu e aos animais selvagens, o que era considerado um horror em Israel. Com um pano estendido sobre os corpos de seus filhos, do início da colheita até o dia que a chuva caiu do céu sobre eles, Resfa não deixou descer sobre eles nenhum animal. Davi, ao saber, não fica indiferente e resgata os ossos de Saul e Jônatas e os sepulta na terra de Benjamim, no túmulo dos pais de Saul (cf. 2Sm 21,1-14).

A narrativa utiliza técnica de compatibilizar duas atitudes opostas: a de Davi e a de Resfa, para fazer distinguir a "lei" do "direito". 308 Davi é a "razão do Estado" e Resfa personifica o "direito" de uma mãe de enterrar seus filhos. Embora pareça cruel, Davi age para enfrentar uma crise e, em respeito à lei e aos costumes da época, age com justiça e responsabilidade, confirmados na consulta que faz a YHWH (cf. 2Sm 21,1). Resfa é vítima inocente de decisões legítimas, mas que vão contra o direito inerente ao seu papel de mãe. Não protesta, mas com nobreza impede que os corpos de seus filhos sofram nova humilhação.

O relato de Resfa mostra como uma mulher de Israel, ao exigir respeito e dignidade com o corpo de seus filhos mortos, garante seu "direito" e, opondo-se à razão do Estado, faz seu direito prevalecer à “lei”. E Resfa faz isso sem alarde, apenas reage. Ninguém pode ficar indiferente ao seu comportamento. No entanto, o autor dá ao relato do sofrimento de Resfa um tom frio e objetivo e sem julgamento. $^{309}$

\footnotetext{
${ }^{307}$ Cf. J.-L. SKA, O canteiro do Pentateuco, p. 77.

${ }^{308}$ Segundo J.-L. SKA (O canteiro do Pentateuco, p. 123-124), a lei é limitada no espaço e no tempo; deve ser proclamada e tem validade enquanto não for modificada; o direito não é proclamado e "não depende de nenhum modo de uma autoridade humana"; "o direito é superior às leis porque é mais antigo".

${ }^{309}$ Cf. J.-L. SKA, O canteiro do Pentateuco, p. 129-134.
} 
A mulher, a familia e o trabalho

As jovens eram livres e, quando 2Mc 3,19 fala das jovens em Jerusalém, confinadas em suas casas, ele se refere a uma situação rara, no contexto do período grego. O véu usado para cobrir as mulheres foi de época mais tardia, no antigo Israel as mulheres não viviam enclausuradas e saíam sem véus: vigiavam e conduziam o rebanho (cf. Gn 29,6); buscavam água (cf. Gn 24,13; Ex 2,16-22; 1Sm 9,11); apanhavam as espigas deixadas pelos segadores (cf. Rt 2,2-7); faziam visitas (cf. Gn 34,1); falavam com os homens sem constrangimento (cf. Gn $24,15-21 ; 29,11-12 ; 1 \mathrm{Sm} 9,11-13)$. Certamente por isso, as moças solteiras causavam inquietação e preocupações aos pais (cf. Eclo 42,9). ${ }^{310}$

A liberdade de sair sozinha pode ser vista no episódio de Siquém (cf. Gn 34,1-31), quando Diná, a filha que Lia dera a Jacó, saiu para ver as "filhas da terra" (cf. Gn 34,1). Este relato mostra uma realidade diferente do que se tem apregoado sobre a falta de autonomia da mulher do antigo Israel: Diná é jovem e tem liberdade para fazer visitas, inclusive a estrangeiras. Siquém a encontra e a violenta. O jovem passa a amar Diná e quer casar com ela (cf. Gn 34,12). A lei determinava que se uma jovem fosse seduzida, o culpado deveria entregar o

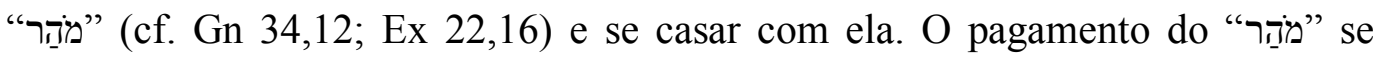
configurava um "presente de compensação". 311

Tem sido rejeitada nos últimos tempos a concepção de que a mulher era propriedade do marido, relacionada junto com seus bens. "O que o homem possuía era a sexualidade de sua esposa, não sua pessoa." O termo "מָֹרֵ" tem o sentido de "uma transferência da autoridade sobre uma mulher, de um homem para outro". Ao constituírem uma unidade legal, um crime de natureza sexual contra a esposa era considerado ofensa contra $o$ marido e não à sua propriedade. $^{312}$ A posição da mulher na sociedade, passiva, submetida, considerada como um bem do homem, foi questionada, modificada e rejeitada em

\footnotetext{
${ }^{310}$ Cf. R. De VAUX, Instituições de Israel no Antigo Testamento, p. 52-55.

${ }^{311}$ Cf. R. L. SMITH, Teologia do Antigo Testamento., p. 240-242. De acordo com R. De VAUX (Instituições de Israel, p. 48-49), fora do casamento, o "מהַר" podia ser pago na venda de uma moça por seu pai ou outro homem, para ser concubina de quem a comprava ou do filho dele, e era considerada uma escrava que podia.

${ }^{312}$ Cf. R. L. SMITH, Teologia do Antigo Testamento, p. 240-242.
} 
anos recentes. ${ }^{313}$ Rute, com sua atitude decidida e firme, desfaz essa imagem de passividade, pois ela age em equilíbrio com a atuação de um homem, Booz. ${ }^{314}$

Isso pode ser visto com as mulheres estéreis com poder de ação e decisão, levando os homens a realizarem as promessas de bênçãos de YHWH de muitos descendentes para Israel (cf. Ex 23,26; Dt 7,14). Sentiam-se livres e independentes quando se tratava de concretizar uma realização pessoal, como ter filhos, uma honra desejada no antigo Israel (cf. Gn 26,4). ${ }^{315}$ Uma prole numerosa junto com a terra fértil eram heranças divinas (cf. Gn 12,1-2) engrossava o coro e aumentava a pressão nos debates levados aos portões da cidade e defendia a família em situações de conflitos e guerras (cf. S1 127). ${ }^{316}$ A esterilidade, ao

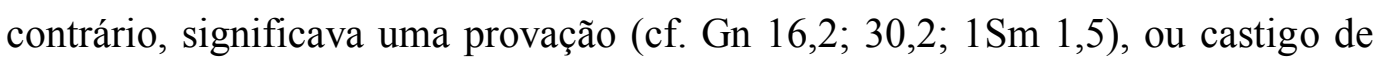
YHWH (cf. Gn 20,18). Assim, algumas mulheres como Sara, Raquel e Lia, estéreis, não se sujeitaram e procuraram se livrar da vergonha adotando o filho que o marido gerou com uma escrava (cf. Gn 16,2; 29,31; 30,3-13). ${ }^{317}$

Sara, no entanto, apesar de representar um personagem bíblico importante na formação da identidade do antigo Israel, nem sempre é devidamente considerada no tema da promessa-aliança. Somente através de Sara, Abraão obteve, legalmente, o direito de posse da terra prometida. A vida de Sara é um convite a permanecer na fé, buscando a justiça. ${ }^{318}$

A narrativa de Gênesis mostra como Sara lidou com a esterilidade (cf. Gn 15,1-6). Na dinâmica de Gênesis, é possível que Abraão estivesse disposto a esperar por YHWH para que se cumprisse a promessa de dar-lhe um filho, mas Sara, sem esperança, apelou para a maternidade por sub-rogação, uma transferência de direito como prática socialmente respeitável nas culturas do Oriente Próximo, e pediu que Abraão tomasse sua serva, Agar, para gerar filhos

\footnotetext{
${ }^{313}$ Cf. R. L. SMITH, Teologia do Antigo Testamento, p. 240-242; R. De VAUX, Instituições de Israel no Antigo Testamento, p. 48-52.

${ }^{314}$ Cf. A. S. VIEGAS, Uma heroína chamada Rute: análise narrativa e intertextual de Rt $3, p$. 19-23.

${ }^{315}$ Cf. também Rt 4,11-12; Pv 17,6; S1 128,3.

${ }^{316}$ Cf. L. A. FERNANDES, "A família conduzida pela palavra de Deus: Salmo 127". In: L. A. FERNANDES; M. GRENZER, Dança, ó Terra! Interpretando Salmos. São Paulo: Paulinas, 2013, p. 140-141; 215-245.

${ }^{317}$ Cf. R. De VAUX, Instituições de Israel no Antigo Testamento, p. 64-65.

${ }^{318}$ Cf. E. C. DIAS, A vida de Sara e o cumprimento da promessa-aliança: exegese narrativa de Gn 23,1-20. Rio de Janeiro, Tese Doutorado - Departamento de Teologia, Pontifícia Universidade Católica do Rio de Janeiro (2016), p. 20-38. 237-244.
} 
através dela. Assim, Agar gerou Ismael. ${ }^{319}$

A história de Lia se agrava porque além de estéril não era amada pelo marido. Jacó apaixonara-se por Raquel e, por causa de uma trapaça do pai da noiva, casou-se com a irmã, Lia, e só mais tarde casou-se com Raquel. Talvez Jacó, por amar Raquel, nem considerasse Lia como sua esposa, e não amasse os filhos que teve com ela. Mas Lia amava Jacó, como se pode ver pelos nomes que deu a seus filhos com ele: Rúben - "YHWH viu minha aflição"; Simeão "YHWH viu que eu não era amada e me deu também este"; Levi - "desta vez meu marido se unirá a mim porque eu lhe dei três filhos"; Judá - "desta vez darei glória a YHWH” (cf. Gn 29,31-35).

Raquel, por sua vez, ficara enciumada, pois Lia gerara filhos e ela não. Jacó podia amá-la, mas o que ela desejava eram filhos. Raquel faz como Sara, apela pela maternidade por sub-rogação através de sua serva Bala que gerou dois filhos para Jacó (cf. Gn 30,1-8). Lia reage a Raquel e, tendo parado de gerar filhos, deu sua serva Zelfa para gerar mais dois filhos para Jacó (cf. Gn 31,9-13).

Lia queria conquistar o amor de Jacó, mas Raquel, com ciúmes, não permite que Lia durma com o esposo. Lia negocia com Raquel algumas mandrágoras que seu filho achara, para que Jacó possa dormir com ela. No antigo Israel, as mandrágoras eram conhecidas por estimularem desejo sexual e aumentarem a fertilidade. ${ }^{320}$ Lia negociou seus direitos e contratou o próprio marido por uma noite e Jacó, que fora servo do sogro Labão, tornou-se servo de Lia por algumas mandrágoras. Na narrativa, Lia engravida graças à intervenção divina. O papel de Jacó na narrativa limita-se, em grande parte, a gerar filhos (cf. Gn 30, 14-24). ${ }^{321}$

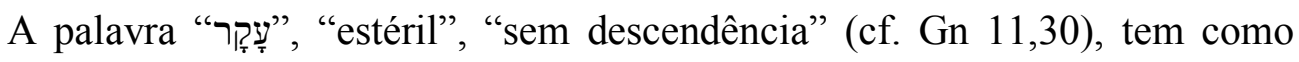
raiz "עקר", cujo sentido é o de "desarraigar". ${ }^{322}$ Esta raiz remete ao arranjo dessas três mulheres que "arrancaram pela raiz" a honra pessoal desejada de se tornarem mães. Elas "desenraizaram" também o destino de Israel, fazendo cumprir a promessa divina de muitos descendentes (cf. Ex 23,26; Dt 7,14). ${ }^{323}$

O autor não reluta em colocar por escrito a prática de mulheres gerarem filhos através de suas servas, embora ele mesmo critique. Esta crítica repercute

\footnotetext{
319 Cf. G. J. WENHAM, "Gênesis". In: D. A. CARSON; R. T. FRANCE; J. A. MOTYER; G. J. WENHAM, CBVN. São Paulo: Vida Nova, 1994, p. 92-149.

${ }^{320}$ Cf. G. J. WENHAM, "Gênesis”. In: CBVN, p. 92-149.

${ }^{321}$ Cf. P. A. VIVIANO, "Gênesis", Comentário bíblico, p. 55-99.

${ }^{322}$ Cf. W. L. HOLLADAY, "עָּקָרָר". In: LHAAT, p. 399.

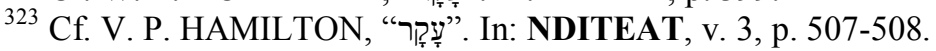


como resultado da prática de sub-rogação da maternidade, quando o redator acrescenta o olhar de desprezo de Agar e o consequente maltrato sofrido (cf. Gn 16,4.6), e que, apesar do negócio das mandrágoras, Raquel ainda não tinha tido filhos com Jacó, enquanto Lia tem mais três (cf. Gn 30,14-21). Mais tarde, "YHWH se lembrará" de Raquel, que engravidará, e o autor lembrará que foi por graça divina e não pelas mandrágoras que ela se tornou mãe (cf. Gn 30,22-24). YHWH ainda atenderá ao pedido de Raquel para mais um filho (cf. Gn 30,24), mas ela morrerá ao dar à luz Benjamim (cf. Gn 35,16-20). Desta união conturbada de Jacó com Raquel e Lia nasceram os doze antepassados das tribos israelitas, entre eles, Rúben, Simeão e Levi. Com o nascimento destes meninos as promessas feitas a Abraão caminharam na direção do seu cumprimento. ${ }^{324}$

Séfora mostra bem essa relação entre marido e mulher ao salvar a vida de Moisés (cf. Ex 4,24-26). Quando YHWH se aproxima para matá-lo, Séfora encontra a solução realizando um ritual (circuncisão), fazendo com que YHWH se afaste e desista do feito. Somente Séfora fala na narrativa e sua fala direta "a faz crescer no conceito do ouvinte-leitor". O ritual realizado por Séfora tem grande significado para o povo judeu, pois o distingue de outros povos e sela o compromisso de aliança com YHWH e das obrigações que dela decorrem. O ritual realizado por Séfora é completo no que tange à matéria (circuncisão do prepúcio), à forma (o gesto acompanhado da fala) e ao significado. Séfora atua como mediadora, salvando Moisés e o filho da morte, e se põe na linha de atuação das parteiras (Ex 1,15-31), da mãe e da irmã de Moisés, e da filha do faraó (Ex 2,1-10). Séfora sabia o que fazer e como fazer para evitar a morte e faz o que era atribuição do pai no antigo Israel (Gn 21,4). Uma questão de morte tem solução nas mãos de uma mulher, que se mostra protagonista no processo de libertação do povo judeu na história do antigo Israel. Vê-se que o grande líder foi salvo pela ação de mulheres. ${ }^{325}$

Apesar da importância dada à fecundidade, e de Moisés ser um grande líder e herói do povo da aliança, sua esposa Séfora, a madianita, e seus filhos tiveram pouca atenção por parte dos autores da Bíblia (cf. Ex 2,16-22). No relato do Êxodo, muito tempo depois de casar com Séfora, Moisés sai de Madiã com ela e

\footnotetext{
${ }^{324}$ Cf. G. J. WENHAM, “Gênesis”. In: CBVN, p. 92-149.

325 L. A. FERNANDES, "Séfora: a mulher proativa que livra o homem da morte (Ex 4,24-26)". In: Revista de Cultura Teológica, XXII/86 (2015), p.59-84.
} 
"os filhos" para o Egito (cf. Ex 4,20). Em capítulos subsequentes, Moisés sai do Egito e "encontra-se" com Séfora e o sogro Jetro no deserto, como se Séfora nunca tivesse saído de Madiã, e Jetro apresenta os filhos de Moisés: Gersam e Eliezer (cf. Ex 18,1-7). Verificam-se três contradições: a) o nome do sogro de Moisés, que no início é chamado de Raguel (cf. Ex 2,18), e mais tarde Jetro (cf. Ex 3,$1 ; 4,18 ; 18,1)$; b) a localização de Séfora que deveria estar no Egito e aparece no deserto, vinda de Madiã; c) o número de filhos de Moisés: em Madiã, Séfora dá à luz Gersam (cf. Ex 2,22); ao receber o chamado divino, Moisés volta ao Egito com Séfora e "seus filhos" (cf. Ex 4,20); Moisés se encontra no deserto com Séfora, seus filhos Gersam e Eliezer, e Jetro que se apresenta como "seu sogro que venho acompanhado de tua esposa e teus dois filhos" (cf. Ex 18, 1-12). Embora o relato acrescente ardilosamente que "Jetro tomou Séfora, depois que Moisés a enviara" (cf. Ex 18,2), esta é a única alusão que se faz do envio da mulher de Moisés a Madiã. As lacunas sobre a vida de Séfora ao lado de Moisés indicam que a narrativa nasceu de tradições distintas, que dão pouca atenção à participação desta madianita na história de Israel, ou talvez seja uma tentativa de desvalorizar Séfora porque fosse mulher, ou porque era estrangeira. ${ }^{326}$

A diferença de posição dos redatores bíblicos pode ser vista no relato em que Sara exige que Abraão expulse Agar, a serva egípcia, e Ismael, seu filho para o deserto (cf. Gn 21,8-21). Sara teve medo que o filho que Abrão tivera com Agar fosse herdeiro com o filho dela, Isaac, o filho da promessa. ${ }^{327}$ Neste relato se pode perceber a mão de dois redatores, um primeiro que mostra Abraão reagindo com firmeza à exigência de Sara, outro que coloca um Abraão passivo, que somente cede às exigências de Sara quando YHWH diz que o faça e lhe assegura que Ismael será pai de uma grande nação. O segundo redator faz um retrato dramático da partida de Agar e Ismael e do desespero da mãe, quando a falta de água ameaça sua vida e de seu filho. YHWH intervém assegurando o futuro dos dois e o redator enobrece Abraão e apresenta Agar não mais como aquela que desprezou Sara, mas como uma mãe zelosa e amorosa. ${ }^{328}$

Contrário à visão usual que se tem da posição da mulher no AT, este relato mostra também a autoridade de uma esposa sobre seu marido. No encontro de

\footnotetext{
${ }^{326}$ Cf. F. CRÜSEMANN, A Torá, p. 348-349.

${ }^{327}$ Cf. E. C. DIAS, A vida de Sara e o cumprimento da promessa-aliança, p. 127-128.

${ }^{328}$ Cf. P. A. VIVIANO, "Gênesis", Comentário bíblico, p. 55-89.
} 
Agar com o mensageiro de YHWH, perto da fonte, no deserto, o narrador poderia tomar três caminhos: a) descrever a satisfação de Sara e a reação de Abraão, concentrando a atenção nestes dois personagens; b) concluir o relato retomando as duas situações, de um lado Abrão e Sara e do outro Agar e Ismael; ou c) descrever como Agar sobreviveu no deserto. Embora a tendência do narrador seja preferir os acontecimentos mais dramáticos, é provável que tenha escolhido o terceiro caminho pelo interesse no destino de Agar, por ser a mãe de Ismael, antepassado dos ismaelitas, personagem importante no ciclo de Abraão (cf. Gn 12-25). Além disso, a Bíblia se interessa pela sorte das mães e dos seus filhos, não só pelos acontecimentos dos homens. $\mathrm{O}$ narrador preocupou-se em tratar da sorte de uma mãe estrangeira e escrava, passando muito tempo em companhia dela. ${ }^{329}$ Se por um lado "a Bíblia raramente ouve a voz do povo", que resolvia seus problemas do próprio jeito, por outro não hesita em reconhecer pessoas que, segundo a mentalidade dominante, são consideradas inferiores. ${ }^{330}$

A questão da esterilidade é preocupação também de Ana, mãe de Samuel (cf. 1Sm 1-2). Ana assegura a continuidade da obra histórica de YHWH quando, desesperada com sua esterilidade, orou e buscou na súplica a transformação da dupla situação de humilhação com a falta de filhos e a fecundidade da outra esposa do marido. Atendida em seu gesto de oração, concebeu Samuel, que se tornou uma figura proeminente, profeta no meio do povo (cf. 1Sm 1,1-28). ${ }^{331}$

Relatos bíblicos não só reconhecem a mulher como "pessoa", como the atribuem autonomia: uma "mulher rica" constrói "um quarto de tijolos no terraço, com cama, mesa, cadeira e lâmpada" para hospedar Eliseu (cf. 2Rs 4,8-10); uma perfeita dona de casa "examina um terreno e o compra com o que ganha e com as mãos planta uma vinha; seus negócios vão bem, e à noite sua lâmpada não se apaga" (cf. Pr 31,16.18); embora seja uma questão em aberto, entre os cananeus as mulheres possuíam direitos especiais como, por exemplo, de dispor da propriedade. ${ }^{332}$

Em síntese, não se pode falar que houve piora da situação da mulher no período persa. Embora as fontes sejam ambíguas em relação ao assunto, observa-

\footnotetext{
${ }^{329}$ Cf. J.-L. SKA, O canteiro do Pentateuco, p. 68-72.

${ }^{330}$ Cf. J.-L. SKA, O canteiro do Pentateuco, p. 72.184.

331 Cf. P. J. BOWES, “1 e 2 Samuel”. In: D. BERGANT; R. J. KARRIS (orgs.), Comentário bíblico, v. 1, p. 248-249.

${ }^{332}$ Cf. E. S. GERSTENBERGER, Israel no tempo dos persas, p. 117.
} 
se que em textos mais tardios a mulher é relatada com mais autonomia dentro do sistema patriarcal, e que a desvalorização e a suspeição surgiram no pós-exílio. ${ }^{333}$

A comunidade judaica pós-exílica, vivamente influenciada pela cultura de outros povos, vivia momentos de transformações das instituições da sociedade, cuja base era a família. O desenvolvimento da economia nacional, com a substituição do modelo de subsistência pelo de comércio de alimentos, baseada em relações de mercado, diferenciação de profissões, que antes eram majoritariamente exercidas pelo homem, permitiu uma maior divisão de trabalho entre homem e mulher no casamento. Tanto a influência cultural quanto os novos tempos da economia podem ter auxiliado a mulher a obter mais autonomia. ${ }^{334}$

\section{A mulher, o divórcio e os bens materiais}

O casamento misto é uma questão polêmica que envolve as mulheres da comunidade judaica do pós-exílio. Submetido a Esdras, o assunto o deixou desesperado e aflito (cf. Esd 9,1-2.12), levando-o a considerar a reaplicação, em novas situações, de leis que talvez estivessem defasadas. Para isso, de diferentes passagens da Escritura extraiu princípios teológicos das leis mais antigas, aludindo a um conceito de santidade entendido como separação do profano.

As pessoas passaram a considerar que os casamentos mistos eram como os casamentos proibidos aos seus ancestrais com cananeus, heteus, ferezeus, jebuseus, amonitas, moabitas, egípcios e amorreus, povos relacionados por Esdras (cf. Esd 9,1-3; 10,10-15; Ne 13,23-30), que em sua maioria não existiam mais. Trata-se da mesma lista dos sete povos que ocupavam Canaã quando os israelitas lá chegaram, na qual foram incluídos os egípcios (cf. Dt 7,1; Js 24,11). A reaplicação de antigas leis ia também ao encontro do desejo de afastar da comunidade também os samaritanos, povo do antigo Reino do Norte, desprezado por ter se tornado uma raça misturada depois da invasão assíria (cf. Esd 4,1-5).

Esdras jejuou e chorou (cf. Esd 9, 3-15), e o povo então o procurou com a proposta de expulsão das esposas estrangeiras e filhos (cf. Esd 10, 1-4). Os divórcios tinham gerado consideráveis problemas sociais, acarretando grande número de mulheres judias abandonadas por causa da preferência por estrangeiras.

\footnotetext{
${ }^{333}$ Cf. E. S. GERSTENBERGER, Israel no tempo dos persas, p. 117.

${ }^{334}$ Cf. E. S. GERSTENBERGER, Israel no tempo dos persas, p. 121-128.
} 
Com a situação de extrema pobreza em Judá do pós-exílio, os casamentos mistos se tornaram atrativos pela possibilidade de ascensão social através da condição econômica do cônjuge e dos dotes oferecidos aos noivos (cf. Ne 6,18; $13,28){ }^{335}$

O divórcio não era novidade em Israel, onde uma lei permitia ao marido repudiar a esposa, em condições especiais, e a repudiada podia recasar várias vezes, exceto com o primeiro ex-marido (cf. Dt 24,1-4). Mas o que era ocasional aumentou, trazendo grandes transtornos. Embora a comunidade do pós-exílio tivesse um governador (cf. Ml 1,8; $\mathrm{Ag} \mathrm{1,1;} \mathrm{Ne} \mathrm{5,14),} \mathrm{a} \mathrm{autoridade} \mathrm{civil} \mathrm{se}$ encontrava enfraquecida e os sacerdotes, que assumiram o comando de Judá, mostravam-se irresponsáveis e não coibiam abusos relativos ao culto, desvios morais, sociais e casamentos mistos, inclusive dos próprios sacerdotes (cf. Esd 10,18-44).

O problema foi denunciado como um pecado da comunidade pelo profeta Malaquias, para quem o divórcio afetava a todos, marido, mulher, filhos, ambas as famílias e sociedade, uma ofensa à vida e quebra da aliança testemunhada por

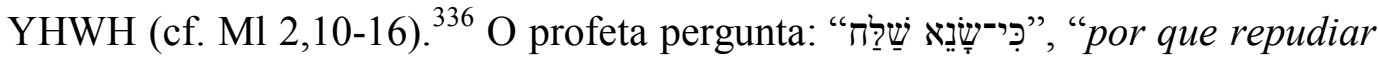
por ódio?". Um redator emendou o texto, para tentar harmonizar as palavras do profeta com a permissão do divórcio estabelecida em lei (cf. Dt 24,1). ${ }^{337}$

Os casamentos mistos eram proibidos desde muito tempo (cf. Dt 7,1-6), mas a comunidade não tomava conhecimento das normas ou não as seguia (cf. Esd 9,1-10,44; $\mathrm{Ne} 13,23,31)$. O povo reconheceu que não observava a lei e confessou sua culpa (cf. Ne 9), pois para pertencer ao povo da eleição deveria seguir a lei (cf. Dt 23,4-6; Ne 13,1-13). Tomando a confissão de Esdras como pano de fundo (Esd 9), outra fonte relata as decisões e atitudes tomadas em relação aos casamentos mistos (cf. Esd 10). Sequenias, um leigo, confessa a culpa da comunidade (cf. Esd 10,2) e propõe despedir as esposas estrangeiras e seus filhos de seus lares (cf. Esd 10,3).

\footnotetext{
${ }^{335}$ Cf. D. KIDNER, Esdras e Neemias. São Paulo: Vida Nova, 1979, p. 74-78.109-111.144-145; PAZDAN, M. M., "Malaquias". In: D. BERGANT; R. J. KARRIS (orgs.), Comentário bíblico, v. 2. São Paulo: Loyola, 1989, p. 176-181.

${ }^{336} \mathrm{Cf}$. também Gn 31,50; Pv 2,17.

337 Cf. J. G. BALDWIN, Ageu, Zacarias e Malaquias, p. 194-202; PAZDAN, M. M., "Malaquias", p. 176-181; G. P. HUNGENBERGER, "Malaquias". In: D. A. CARSON; R. T. FRANCE; J. A. MOTYER; G. J. WENHAM (orgs.), Comentário bíblico Vida Nova. São Paulo: Vida Nova, 2009, p. 1224-1335.
} 
A leitura das passagens da Escritura feita por Esdras levou um grande número de pessoas a se reunir, chorando em torno dele em uma assembleia (cf. Esd 10,1). Depois, em nova assembleia, "todo o povo de Israel" se pôs a tremer ao tratar do assunto (cf. Esd 10,9). ${ }^{338}$ Esdras se levanta e determina que se separem dos outros povos da terra e das mulheres estrangeiras (cf. Esd 10,10-11). Nada é dito a respeito dos esposos estrangeiros, que certamente existiam depois de dois exílios e da situação da própria Judá misturada.

Muitas questões envolviam o problema dos casamentos mistos levantado pelos "chefes" da comunidade junto a Esdras (cf. Esd 9,1). No que resultaria o repúdio às esposas estrangeiras? As mulheres estrangeiras tinham algum direito ao ser repudiadas? Voltariam talvez para a casa dos pais em outras terras? Em Israel, assim como na Mesopotâmia, e em Elefantina, o marido devia redigir um documento de repúdio (cf. Dt 24,1; Is 50,1; Jr 3,8) e a mulher, divorciada, poderia voltar a casar (cf. Dt 24,2). Não há uma lei que fale sobre a mulher pedir o divórcio em Israel, o que era aceito em Elefantina, que sofrera influência estrangeira. $^{339}$

A comunidade judaica de Elefantina entrara em conflito com a comunidade local da Ilha $(Y e b)$ e, tendo seu Templo destruído, dirigiu-se às autoridades persas para obter autorização para reconstruí-lo. Uma carta foi dirigida ao governador persa da Judeia, pedindo apoio à solicitação que fizeram aos persas, o que demonstra as boas relações entre as duas comunidades, Judá e Elefantina (cf. Ne $2,10.19 ; 13,28) .{ }^{340} \mathrm{O}$ contato relativamente fácil entre os povos destas províncias pode ter influenciado as mulheres judias e estrangeiras de Judá em relação aos pedidos de divórcio e conservação de bens.

As mulheres de Judá sofreram influência também de outras culturas nas relações com outros povos durante o exílio. Na Mesopotâmia, o código de Hamurabi estabelecia uma compensação para a esposa no caso de divórcio, o que tornava o divórcio desfavorável aos maridos, assim como em Elefantina. Se o marido repudiava a esposa, ele não podia reclamar o "מהַר e, além de pagar o "preço do divórcio", a esposa podia conservar tudo o que havia levado para o

\footnotetext{
${ }^{338}$ Cf. R. J. BURNS, “Esdras e Neemias”, p. 303-332.

${ }^{339}$ Cf. R. De VAUX, Instituições de Israel do Antigo Testamento, p. 57-59.

${ }^{340}$ Cf. J. L. SKA, O canteiro do Pentateuco, p. 233-234.
} 
casamento. Nos casos em que a esposa repudiava o marido, ela pagava o "preço do divórcio" e conservava os bens pessoais e o "מָהָר".

É provável que por isso o povo, chamado a resolver o assunto, pediu mais tempo alegando serem muitos naquela situação e estar em plena estação das chuvas (cf. Esd 10,13). A ordem de Esdras não atingia estrangeiros que haviam esposado mulheres judias, estes não precisariam separar-se. Contudo, a lei que Esdras diz que o povo transgrediu, proibia o casamento tanto de mulheres israelitas com estrangeiros, como de homens israelitas com estrangeiras (cf. Dt $7,1-4) .^{342}$

Como o AT nada fala sobre uma provável proteção dos pais às filhas, caso fossem repudiadas por seus maridos, através de cláusulas específicas e onerosas como acontecia com as estrangeiras, imagina-se que a esposa judia repudiada ficasse abandonada ou voltasse para a casa dos pais. Numa situação já precária, isso afetava ainda mais a comunidade. Mas, se o judeu repudiasse sua esposa estrangeira, como ordenara Esdras, ele agiria segundo a lei e os costumes da esposa ou a lei de YHWH? Os bens e propriedades das esposas estrangeiras pertenceriam à comunidade de Judá?

Esdras desejava desenvolver uma comunidade estritamente religiosa, conforme incumbência dada por Artarxerxes (cf. Esd 7,12-26), mas lidava com a desastrosa situação econômica e social de Judá. Para atingir seu objetivo, determinou a proibição de casamentos mistos, com o que tentava manter os bens da comunidade e fortalecer o sentimento de identidade naqueles que já se haviam redefinidos como “povo de Israel” (cf. Esd 2,1-58). ${ }^{343}$

Não se fica sabendo o que aconteceu com o grande número de mulheres que deveriam ser banidas de seus lares. Os relatos bíblicos sobre o assunto não esclarecem o ocorrido. A exclamação de Sequenias, após sua determinação de despedir as esposas estrangeiras e seus filhos: "Que seja feito conforme a lei" (cf. Esd 10,3) é enigmática, pois a lei proibia o casamento com estrangeiros, homens e mulheres (cf. Ex 34,16; Dt 7,1-4), mas não determinava o que fazer com casos já existentes.

\footnotetext{
${ }^{341}$ Cf. R. De VAUX, Instituições de Israel do Antigo Testamento, p. 57-59.

${ }^{342}$ Cf. R. J. BURNS, "Esdras e Neemias", p. 318.

${ }^{343}$ Cf. H. G. M. WILLIAMSON, "Esdras e Neemias". In: CBVN, p. 640-671.
} 
Durante a ausência de Neemias, a prática de esposar estrangeiras voltou a acontecer, ou talvez não tenha sido interrompida, conforme ele constatou ao ouvir crianças falando a língua de outros povos, sem saber o hebraico (cf. Ne 13,23-24). É possível que fosse somente sotaque ou algum tipo de pronúncia diferente, mas Neemias viu nisso a perda da identidade judaica e reagiu com violência, admoestando, amaldiçoando, arrancando os cabelos e dando ordens para que não deixassem os filhos praticarem casamentos mistos, e lembrou o pecado de Salomão (cf. 2Sm 12,25ss; 1Rs 11,1-10). Embora a reação de Neemias tenha sido violenta, diferentemente de Esdras, ele não determina a expulsão das esposas estrangeiras, mas ressalta os efeitos negativos que mulheres estrangeiras acarretaram para Salomão. As mulheres eram parte essencial da comunidade judaica, as filhas não deviam casar-se com estrangeiros e as estrangeiras não deviam tomar o lugar delas na comunidade (cf. Ne 13,23-31).

Estranhamente, os chefes e os sumo sacerdotes eram os que mais haviam esposado estrangeiras. Neemias expulsou Eliasib, filho do sumo sacerdote Joiada, que se tornara genro de Sanabalat (cf. Ne 2,10.19; 3,33-38; 4,1-5; 6,1-14), o horonita, justamente aquele que se opusera à sua missão e ameaçara o fortalecimento da comunidade judaica. Além disso, havia também proibição de um sumo sacerdote casar-se fora da comunidade judaica e Eliasib era candidato potencial ao cargo, o que justificou a reação de Neemias (cf. Ne 13, 23-31). ${ }^{344}$

Também Esdras relata que havia muitos sacerdotes que tinham esposado estrangeiras. Dos 42.360 cidadãos da lista dos repatriados (cf. Esd 2,64), havia 4.289 sacerdotes (cf. Esd 2,36-39), e destes 111 eram casados com estrangeiras, e despediram as mulheres e os filhos (cf. Esd 10,18-44). No entanto, vozes dissonantes são registradas na determinação de expulsar esposas estrangeiras e filhos da comunidade, como as de Jônatas e Jaasias, apoiados por Mosolam e pelo levita Sebetai (cf. Esd 10,15). Não se sabe o motivo da oposição, se estavam apenas sendo zelosos a respeito da questão, se achavam a punição muito severa, se protegiam alguém da comunidade, se eles ou alguém próximo tinha como esposa uma estrangeira ou mesmo se consideravam que não havia exigência legal para a aplicação da medida. ${ }^{345}$

\footnotetext{
${ }^{344}$ Cf. R. J. BURNS, “Esdras e Neemias", p. 332.

${ }^{345}$ Cf. D. KIDNER, Esdras e Neemias, p. 31-79.
} 
Originalmente, a proibição de casamentos mistos (cf. Ex 34,16; Dt 7,3-4) tinha por objetivo evitar diminuir ou dispersar patrimônio da tribo, embora, no período monárquico tivessem aceitado por motivos políticos, como foi o casamento de Salomão com a filha do faraó (cf. 1Rs 3,1), apesar da proibição (cf. 1Rs 11,1-6). A condenação do casamento misto no pós-exílio teve a mesma motivação, medo de perder o patrimônio da comunidade de Judá. Com isso, se conclui que talvez a proibição dos casamentos mistos não tenha sido cumprida, e a narrativa de Esdras e Neemias tenha sido somente uma tentativa de "teologizar" uma situação para a qual não tinham solução imediata. ${ }^{346}$

\section{Sintese}

A história do antigo Israel no pós-exílio que desponta dos relatos bíblicos, ou seja, é a história de YHWH com seu povo. Nesse sentido, os textos analisados mostram os acontecimentos que precederam o retorno dos judeus à Palestina. Após deportações e destruição da cidade de Jerusalém e do Templo, vivendo por décadas no meio de outros povos com outras culturas e religiões, retornaram a Jerusalém para reconstruir a cidade e o Templo. Chegaram pessoas oriundas de lugares diferentes que, inculturadas, deram origem a grupos com ideologias e correntes que se contrapunham, destinados a trabalhar para conceber uma identidade para Israel na nova era. Os grupos eram formados de grandes proprietários de Judá, famílias sacerodotais de Jerusalém, grupos independentes, economicamente poderosos e gente que permanecera na terra. $\mathrm{O}$ grupo que predominou foi o dos retornados do exílio na Babilônia, onde criaram a ideologia de exclusão e pertença, do qual Zacarias fazia parte.

Neste contexto social e religioso, observou-se que a mulher no pós-exílio é protagonista em vários textos onde fica evidente: embora não seja citado de forma explícita, possuía direitos legais; em casos como de repúdio do marido, podia levar questões aos portões da cidade; agia para fazer prevalecer suas necessidades e opções; possuía liberdade de sair sem véus, conduzindo rebanhos, apanhando espigas, visitando amigos e falando com homens; tomava para si a solução de sua esterilidade, contribuindo para o cumprimento da realização das promessas

\footnotetext{
${ }^{346}$ Cf. R. J. BURNS, “Esdras e Neemias", p. 303-332.
} 
divinas; agia em situações adversas para garantir seus direitos; educava os filhos de acordo com sua cultura e religião; podia deter parte dos bens e propriedades da família.

Com isso se conclui que a mulher no pós-exílio não teve declínio de seu status, nem era considerada propriedade do homem, sem voz e sem lugar na comunidade. A ideologia predominante de pertença e exclusão foi atualizada para o novo tempo. Diferentes ideologias foram conciliadas num só documento para publicação dos textos da Sagrada Escritura. A mulher, cujo comportamento desagradava ao grupo predominante, de ideais proféticos de fidelidade a YHWH e às tradições, foi submetida e presa no efá, e sua remoção, cercada de zelo amoroso, atendia aos anseios do grupo de ideias mais liberais. 


\section{5}

\section{O texto, sua constituição e organização}

\section{1.}

\section{Tradução}

Saiu o mensageiro que falava comigo, $\quad 5 \mathrm{a}$ e ele me disse: ${ }^{347} \quad 5 \mathrm{~b}$

Levanta, por favor, teus olhos $5 \mathrm{c}$

e vê: $5 \mathrm{~d}$

Que é isto que está saindo? $5 \mathrm{e}$

Então, eu respondi: $\quad 6 \mathrm{a}$

Que é aquilo? $6 \mathrm{~b}$

E ele disse: ${ }^{[\mathrm{a}]} \quad 6 \mathrm{c}$

Isto é o efá que está saindo. $6 \mathrm{~d}$

E ele disse: $\quad 6 \mathrm{e}$

Isto é o olho deles ${ }^{[\mathrm{b}]}$ em toda a terra. ${ }^{[\mathrm{c}]} \quad$ of

$E$ eis que um disco de chumbo foi $7 a$ levantado

e (eis) isto: ${ }^{[a]}$ uma mulher sentada no $7 \mathrm{~b}$ meio do efá.

E ele disse:

Esta é a iniquidade.

Então, ele lançou-a ${ }^{[a]}$ para o meio do efá, $8 \mathrm{c}$ e ele lançou uma pedra de chumbo para $8 \mathrm{~d}$ sua abertura. ${ }^{[\mathrm{b}]}$

Levantei meus olhos ${ }^{[\mathrm{a}]}$

$\mathrm{e} \mathrm{vi}^{[\mathrm{b}]}$.

E eis que duas mulheres saíram $\quad 9 \mathrm{c}$

e havia vento nas asas delas; $9 \mathrm{~d}$

e elas tinham asas, como asas de 9e cegonha,

e levantaram o efá entre a terra 9f

e os céus.

Então, eu perguntei ao mensageiro que $10 \mathrm{a}$

falava comigo:

Para onde elas estão levando o efá? $\quad 10 \mathrm{~b}$

E ele me respondeu: $11 \mathrm{a}$

Para construir para ele uma casa na terra $11 \mathrm{~b}$ de Senaar, ${ }^{[a]}$

e será preparada, ${ }^{[b]}$

$11 \mathrm{c}$

e lá será assentado ${ }^{[\mathrm{c}]}$ sobre sua base.

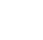

.

c

d

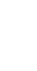

.

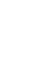

(1)

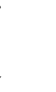




\section{2.}

\section{Notas de crítica textual}

v.6c ${ }^{[a]}$ A LXX, a Vulgata e o Targum leram “e disse” (וְְֵ), enquanto a Siríaca não apresenta o termo, provavelmente por iniciativa do copista para encurtar o texto, sem que se saiba, ao certo, o que motivou a exclusão do verbo nessa versão. A opção pela conservação do texto hebraico justifica-se pelos testemunhos textuais citados, que atestam a presença do verbo "e disse", e pela própria estrutura frasal que não necessita de maiores explicações.

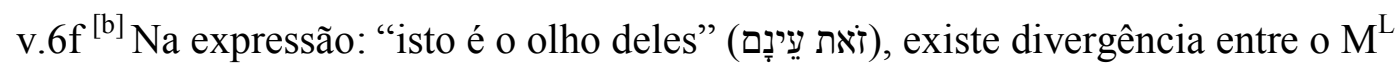
e a LXX. Esta última considera ter havido um erro textual, interpretando "olho

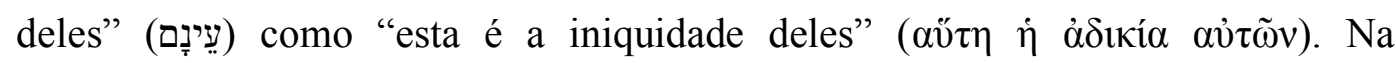
interpretação da LXX, um desgaste textual poderia fazer parecer um yod ao invés de um waw, uma vez que possuem formas semelhantes, gerando a possível confusão, e assim "olho deles" (עָינָם) tornou-se "iniquidade deles" (עָוֹנָם). A Vulgata, provavelmente pressupondo o $\mathrm{M}^{\mathrm{L}}$, lê "este é o olho deles" (haec est oculus eorum). O Targum, que inclui o verbo de raiz "גלן" com o sentido de "partir para o exílio", parafraseia tão livremente o $\mathrm{M}^{\mathrm{L}}$, que se torna impossível determinar sua vorlage. Símaco, também pressupondo o $\mathrm{M}^{\mathrm{L}}$, lê "para eles

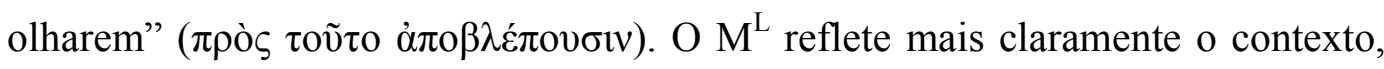
mesmo aparentemente sendo de mais difícil leitura, dando razão à regra de que a lição mais difícil provavelmente é a mais antiga. Uma vez que o texto não dificulta a compreensão, é coerente conservar a expressão como está no $\mathrm{M}^{\mathrm{L}}$.

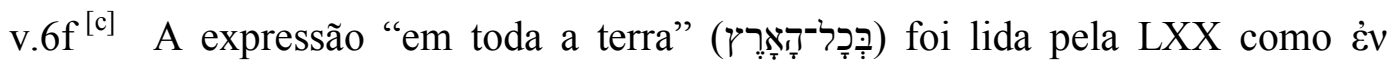

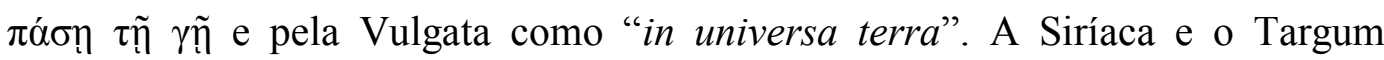
apresentam variação dessa versão, sendo que este último lê livremente "antes de todos os habitantes da terra" (קדם כל יתבי ארעא). Estas variações resultam de como estas testemunhas leram o versículo como um todo. Percebe-se que os termos "antes" e "habitantes" são um acréscimo, e que a expressão "em toda a terra"

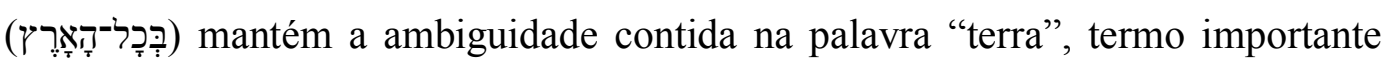
para a interpretação de toda a visão. Mesmo que o $\mathrm{M}^{\mathrm{L}}$ não seja evidentemente claro, ele pode ser compreendido sem necessidade de um ou mais complementos. Neste sentido, é preferível a lição mais breve. 


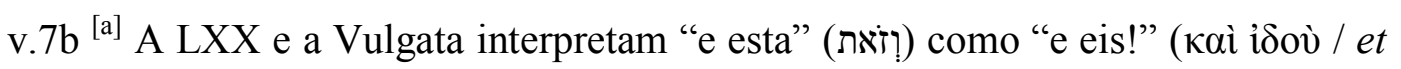
ecce). Não se trata de Vorlage do $\mathrm{M}^{\mathrm{L}}$, mas do uso dêitico dado ao pronome "isto" (זאת). ${ }^{348}$ As testemunhas tentaram eliminar a ambiguidade, enquanto a Siríaca omitiu a expressão “e (eis) isto" (וְז), provavelmente por considerar que a

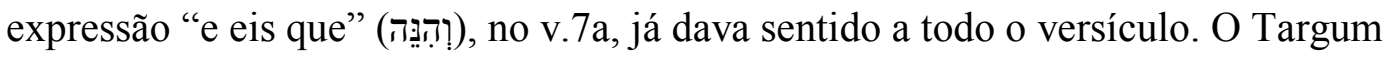

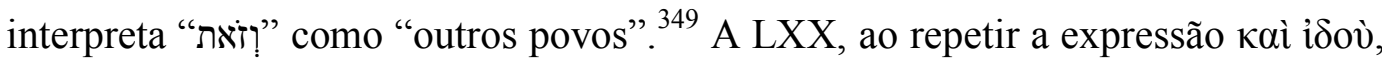
tentou harmonizar o texto dando-lhe maior coerência ao enfatizar a entrada de

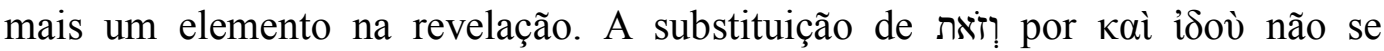
justifica, pelo fato de o $\mathrm{M}^{\mathrm{L}}$ permitir que a expressão parecendo se referir a algo já visto. O pronome זٔאת ocorre em diversas orações (vv. 5e; 6df; 7b; 8b) e oferece destaque aos elementos da visão. A interjeição "e eis que" (إְִֵּנה ) ocorre apenas duas vezes (cf. Zc 5,7a.9c) e introduz elementos novos em ações a fim de complementar a informação. A oração com o pronome demonstrativo não gera dificuldade na leitura, e seu uso, visto no conjunto, faz mais sentido que o uso da interjeição para a compreensão do desvelamento da visão. Deste modo, é preferível continuar seguindo o $\mathrm{M}^{\mathrm{L}}$, entendendo que, geralmente, a lição mais difícil provavelmente é a mais antiga.

v.8c [a] A LXX e a Vulgata interpretam o oblíquo "a" ("ela") (אָתָה),

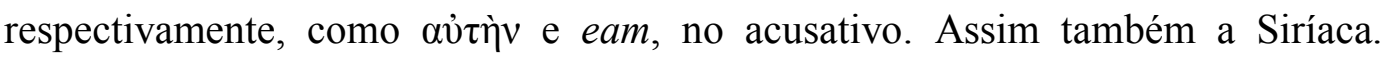
Existe uma nota de Jerônimo ${ }^{350}$ que atribui uma mudança do termo aủ

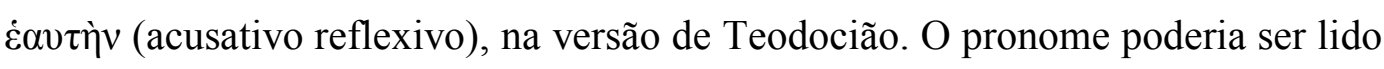
como acusativo reflexivo, pois a oração apresenta o verbo em grego na forma de um aoristo ativo singular que não indica por si só o gênero. No entanto, o $\mathrm{M}^{\mathrm{L}}$ é de fácil entendimento, não havendo dificuldade na compreensão da partícula indicadora de objeto direto por causa do sufixo de $3^{\mathrm{a}}$ feminino singular anexado a ele. A estrutura hebraica é clara ao indicar o gênero do sujeito como masculino singular, e o sufixo da partícula de objeto direto com o gênero bem definido como feminino singular. A substituição é desnecessária e pode ter sido um erro de transmissão no texto de Teodocião.

\footnotetext{
${ }^{348}$ Cf. GHG § 34; 136.

${ }^{349}$ Os textos de Zc 5,5-11 referentes ao Targum foram considerados tendo por base a tradução feita por H. BUNCE "Translation and Interpretation: Targum and Septuagint in Zechariah 5:5-11", p. 55).

${ }^{350}$ Cf. BHQ, v. 13, p. 138.
} 


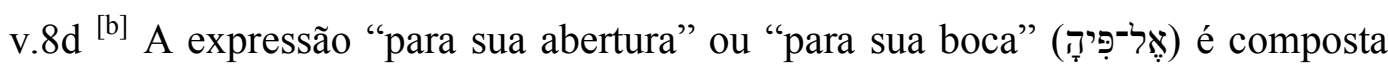
por preposição "para" (אֶ), substantivo masculino "abertura" (לפֶ) e sufixo pronominal feminino singular. Não achando claro se a "pedra" (עִפְרת) foi lançada sobre a abertura do efá ou sobre a iniquidade (cf. Zc 5,8b), a LXX pode ter visto um erro gramatical no texto hebraico e tentou corrigi-lo, entendendo que a pedra foi lançada sobre a "iniquidade", pois o termo ỏvouía é o único substantivo da oração que pode estar relacionado com o pronome genitivo feminino $\alpha \dot{\tau} \tau \tilde{\varphi}$. A leitura da Vulgata, como "in os eius”, da Siríaca e de Qumran não ajudam no entendimento. O Targum troca "boca" por "lugar", sendo, portanto, impossível determinar sua Vorlage. A questão deve ser tratada do ponto de vista exegético e não textual. Por este motivo, preferiu-se preservar o $\mathrm{M}^{\mathrm{L}}$, mesmo porque, de acordo com a regra da gramática hebraica, o pronome é remetido ao substantivo mais próximo, que neste caso é o efá. ${ }^{351}$

vv.9a ${ }^{[a]}$ e $b^{[b]}$ A LXX, a Vulgata, a Siríaca e o Targum concordam quanto ao

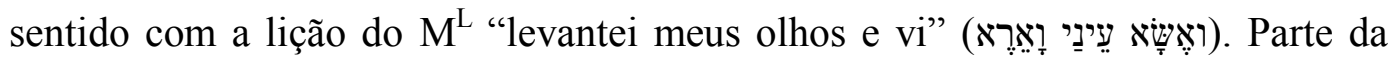
expressão foi omitida no texto original de Qumran (4QXII ${ }^{\mathrm{e}}$ - ואשש]). Neste testemunho, não se encontra a expressão ואָָָּׁ, mas um termo aparentemente corrompido em seu lugar, formado pela junção de duas consoantes אה, e, além disso, percebe-se a omissão da expressão verbal וָארֵּ Uma variante de Qumran

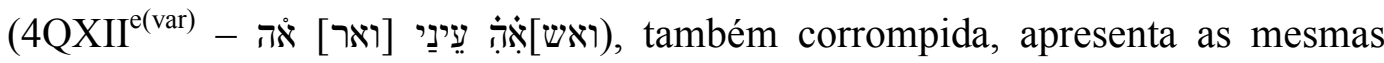
consoantes hebraicas no início e no final da expressão para indicar outra palavra não identificada. É provável que a omissão de וארא tenha sido um erro no texto original de 4QXII e, então, mais tarde foi adicionada acima da linha. É impossível dizer qual mão adicionou os pontos de rasura ao lado das duas primeiras palavras. As correções da variante ajudam a compreender que se tratou de um erro de origem indeterminada. Deste modo, é preferível, por coerência, a manutenção do $\mathrm{M}^{\mathrm{L}}$, uma vez que a expressão é compreensível e está adequada dentro do contexto e recebe apoio das versões.

v.11b ${ }^{[a]}$ A Vulgata leu Sennaar, conservando o nome próprio "Senaar" (שִנְָעָר) dentro de estrutura construta hebraica; a LXX testemunha a expressão no genitivo dentro da estrutura frasal "terra da Babilônia" ( $\gamma \tilde{n}$ B $\alpha \beta \nu \lambda \tilde{\omega} v o \varsigma)$. A Siríaca e o

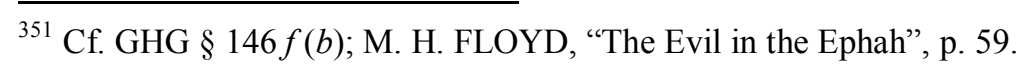


Targum acompanharam esta última. A leitura da LXX parece ser uma interpretação propondo um entendimento para a visão, não sendo possível saber ao certo qual foi a intenção teológica ou ideológica dos tradutores. Cogita-se que a mudança tenha sido feita para que os leitores de língua grega tivessem uma referência mais clara sobre a ação de YHWH. Neste estudo optou-se por manter o

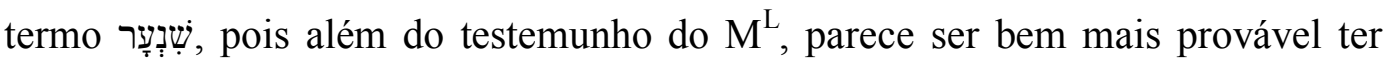
havido a troca do termo "Senaar", de terminologia mais arcaica, por "Babilônia", em um contexto helenizado no qual os referenciais precisavam ter maior clareza e relevância para a comunidade.

v.11c ${ }^{[b]}$ A forma verbal "e será preparada" (וֹהוּכַ), no hofal, é lida pela Vulgata

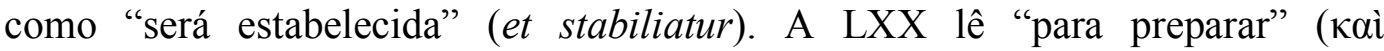

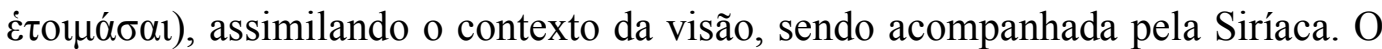
Targum lê "eles serão retidos" (ויתעכבון) no hitpael, que neste caso pode ser interpretado como um passivo, da mesma forma que o $\mathrm{M}^{\mathrm{L}}$.

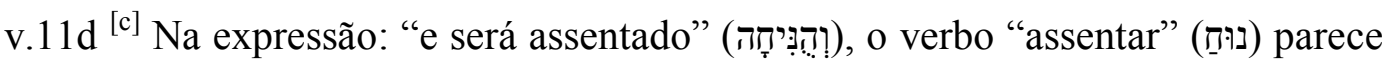
ser uma forma mista de hifil e hofal. A LXX e a Siríaca assimilaram pelo contexto

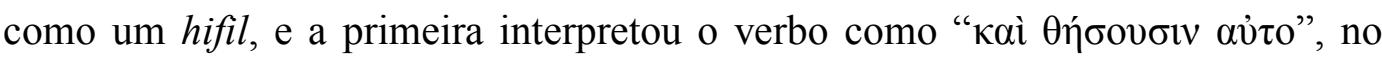
indicativo futuro ativo, supondo o verbo na voz ativa. A Vulgata assimilou o contexto como um hofal e leu "et ponatur". O Targum também assimilou o

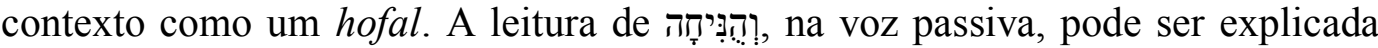

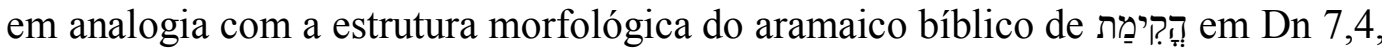
que tem o verbo "ficar de pé" (קוּם), no hofal terceira pessoa do singular, semelhante ao verbo referenciado. ${ }^{352}$ Existe na sentença uma questão relativa à

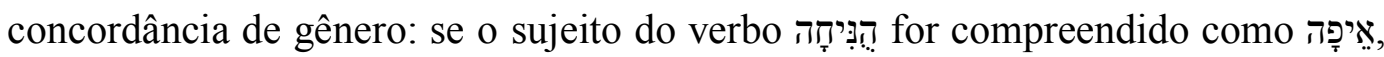
entende-se que há um desacordo entre o verbo (terceira pessoa masculino singular) e o substantivo (feminino singular); se o sujeito for בִּי (masculino

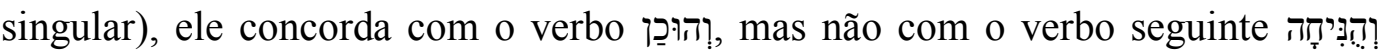
(terceira pessoa feminino singular), sugerindo assim outro sujeito, possivelmente o אֵיפָּ. A leitura das raízes כוח e quanto à forma (hofal), não apresenta problemas para a sua compreensão morfológica. A dificuldade está na relação dos verbos com seus respectivos sujeitos, gerando certa ambiguidade na assimilação

\footnotetext{
${ }^{352} \mathrm{Cf} . \mathrm{GHB} \S 72, \mathrm{IV}, e e$.
} 
da visão. Neste caso, os testemunhos não são determinantes para a resolução da questão.

\section{3.}

\section{Delimitação e unidade}

Zc 1-8 possui três referências cronológicas $(\mathrm{Zc} 1,1 ; 1,7 ; 7,1)$ que apontam para os inícios de subunidades temáticas. ${ }^{353} \mathrm{O}$ início do ciclo das oito visões ( $\mathrm{Zc}$ 1,7-6,15) é indicado por Zc 1,7. ${ }^{354}$ Em geral, esta referência é considerada parte da primeira visão (Zc 1,7-17), ${ }^{355}$ contudo, para alguns estudiosos este versículo foi colocado como um título ou uma introdução para todo o ciclo de visões. ${ }^{356}$

Interpreta-se assim porque a referência cronológica em Zc 1,7 é relatada em terceira pessoa, a partir do ponto de vista de um narrador externo, enquanto o início propriamente dito da primeira visão é dado pelo próprio profeta, em primeira pessoa (Zc 1,8), o que caracteriza uma descontinuidade textual.

Se a referência cronológica em Zc 1,7 não serve de ponto de partida para o estudo do ciclo de visões do profeta Zacarias, deve-se dissociar a datação contida nela inteiramente das visões. Neste caso, fica em aberto se as visões ocorreram todas de uma única vez ou em ocasiões diferentes, ${ }^{357}$ podendo, portanto, deduzirse que cada uma das visões possui um contexto social e religioso particular em que foi recebida. ${ }^{358}$

\footnotetext{
353 Subunidades temáticas: Zc 1,1-6 - introdução da mensagem divina ligando aqueles que retornavam do exílio aos seus pais; Zc 1,7-6,15 - ciclo de visões; e Zc 7,1-8,23 - oráculos sobre o jejum e os bens messiânicos futuros (cf. C. L. MEYERS; E. M. MEYERS, Haggai, Zechariah 18, p. 89; M. M. PAZDAN, “Zacarias". In: Comentário bíblico, p. 155-167).

${ }^{354}$ Para D. L. PETERSEN (Haggai and Zechariah 1-8, p. 112-113), M. HALLASCHKA (Haggai und Sacharja 1-8, p. 139) e J. G. BALDWIN (Ageu, Zacarias e Malaquias, p. 73), o ciclo de visões noturnas $(1,7-6,15)$ possui oito visões $(1,7-17 ; 2,1-4 ; 2,5-17 ; 3,1-10 ; 4,1-14 ; 5,1-4$; 5,5-11; 6,1-15), para K. GALLING ("Die Exilswende in der Sicht des Propheten Sacharja", p. 18), no entanto, são apenas sete visões pois, Zc 3,1-7 não fazia parte da série original das visões, e C. L. MEYERS e E. M. MEYERS (Haggai, Zechariah 1-8, p. liv) não incluem Zc 3,1-7 entre as visões porque consideram que seria uma "visão profética" e não uma "visão simbólica".

${ }^{355}$ Cf. J. G. BALDWIN, Ageu, Zacarias e Malaquias, p. 73; A. E. HILL, "Zechariah", p. $119,131-132$.

356 Cf. C. L. MEYERS; E. M. MEYERS, Haggai, Zechariah 1-8, p. 107-109.125-126; M. J. BODA, The Book of Zechariah, p.107-112.

${ }^{357}$ Duas visões podem ter dado origem a que se pensasse que todas as visões seriam noturnas: a primeira visão (Zc 1,7-17) quando, após a referência cronológica que dá início ao ciclo de visões

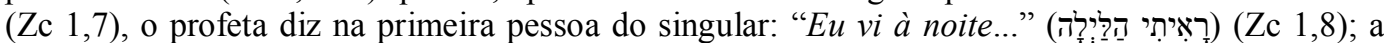
quinta visão $(Z c 4,1-5)$ quando o profeta diz logo no início: “... como um homem que despertou de

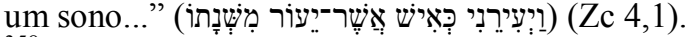

${ }^{358}$ Cf. K. GALLING, "Die Exilswende in der Sicht des Propheten Sacharja", p. 18.
} 
Assim, pode-se afirmar que Zc 5,5-11 é uma visão independente dentro do ciclo de visões, com início caracterizado pela fórmula introdutória: "Saiu o mensageiro que falava comigo e ele me disse: 'Levanta, por favor, teus olhos e vê." (vv.5a-d), ${ }^{359}$ e finalizada com o destino do efá no final da visão: "Para construir para ele uma casa na terra de Senaar, e será preparada, e lá será assentado sobre sua base." (vv.11b-d).

As visões antecedente ( $\mathrm{Zc} 5,1-4)$, subsequente ( $\mathrm{Zc}$ 6,1-8) e a estudada ( $\mathrm{Zc}$ 5,5-11) apresentam os mesmos personagens: YHWH (agente principal implícito); o mensageiro (mediador entre YHWH e o profeta); e o profeta. No entanto, os elementos e temas são totalmente diferentes, o que novamente aponta para uma independência entre elas.

Em relação aos elementos, a visão presente em Zc 5,5-11 tem como elementos principais o "efá" (v.6d), o "olho deles" (v.6f), a "mulher" (v.7b) e a "iniquidade" (v.8b); a visão antecedente tem como elemento central o "rolo que voava" (cf. Zc 5,1) e a "maldição para ladrões e perjuros" (cf. Zc 5,3-4); enquanto que a visão subsequente concentra-se em "quatro carros que saíram dentre duas montanhas, montanhas de bronze" (cf. Zc 6,1).

Em relação aos temas, Zc 5,5-11 trata da remoção dos elementos simbólicos dos pecados praticados na comunidade como forma de apelo e encorajamento à vivência de uma existência mais justa; a visão antecedente (cf. Zc 5,1-4) descreve um livro que voa, a maldição saindo contra ladrões e perjuros, num chamado de fé para aqueles que hesitam entre a verdade de YHWH e a sabedoria humana; a visão subsequente (cf. Zc 6,1-8) trata de um novo tempo, com carros e com cavalos coloridos saindo dentre duas montanhas de bronze, e ventos personificados que percorrem a terra para YHWH, cuja morada é protegida por duas montanhas.

Como visão independente, dentro do ciclo de visões, Zc 5,5-11 apresenta início e fim caracterizados por rupturas com as visões antecedente e subsequente, marcadas pela mudança do sujeito da fala, nos diálogos entre o mensageiro e o profeta. Na visão antecedente (cf. Zc 5,1-4), o oráculo de YHWH, na voz do mensageiro, na primeira pessoa do singular (cf. Zc 5,4), é interrompido pela

\footnotetext{
${ }^{359}$ Segundo C. L. MEYERS e E. M. MEYERS (Haggai, Zechariah 1-8, p. lvii), as introduções das visões seguem um mesmo padrão ao longo do ciclo de visões e são consideradas "fórmulas", entendidas como sentença ou expressão que ajuda o leitor a identificar o início de nova visão.
} 
fórmula de início na visão objeto de estudo, na voz do profeta, na terceira pessoa do singular (cf. Zc 5,5). Em Zc 5,5-11 a voz do mensageiro, na terceira pessoa do singular, em resposta sobre o destino do efá (cf. Zc 5,11), é interrompida pela voz do profeta, na primeira pessoa do singular (cf. Zc 6,1a-c), na fórmula que dá início à visão subsequente (cf. Zc 6,1-8).

A existência de uma segunda fórmula (Zc 5,9ab), semelhante à fórmula inicial, no meio da narrativa, não configura um problema para a unidade de $\mathrm{Zc}$ 5,5-11. Ao contrário, esta fórmula se torna importante e até necessária no contexto da narrativa ao chamar a atenção do leitor para algo que o profeta percebe estar ocorrendo na cena da visão: "Levantei meus olhos e vi..." (vv.9ab). O profeta aponta a cena: "E eis que duas mulheres saíram" (v.9c) sem que se configure uma ruptura da narrativa.

O movimento espacial é um outro aspecto que distingue Zc 5,5-11 das visões antecedente (Zc 5,1-4) e subsequente (Zc 6,1-8):

a) Zc 5,1-4: o movimento tem início no espaço com o rolo voando e termina sobre toda a superfície da terra, com a maldição espalhando-se sobre ela, expulsando ladrões e perjuros, estabelecendo-se no seio das casas deles, destruindo e aniquilando cada uma delas;

b) Zc 5,5-11: existem dois movimentos paralelos, o do profeta, que se encontra na terra e contempla a visão nos céus, e o movimento da visão em si, que tem início na terra, segue no espaço com o efá levantado entre a terra e os céus por duas mulheres com asas como de cegonhas, sendo levado para Senaar, e termina na terra, com o efá numa casa, sobre sua base;

c) Zc 6,1-8: o movimento tem início na terra, com os quatro carros saindo dentre duas montanhas de bronze e percorrendo todos os cantos do mundo; a visão possui conotação bélica com carros e cavalos e "YHWH de toda terra", onisciente em seu espaço divino simbolizado pelos quatro ventos. 
Considerando-se a marca da $s^{e}$ tûmâ ao final do v.11d (indicando uma divisão ou finalização da unidade narrativa), ${ }^{360}$ e a ausência de aspectos formais e temáticos que liguem diretamente $\mathrm{Zc}$ 5,5-11 aos textos antecedente e subsequente, conclui-se que se trata de uma unidade literária com nexo e sentido, coesa e independente, com início, meio e fim, possuindo organização bem elaborada. ${ }^{361}$

\section{4 .}

\section{Organização do texto}

\subsection{1.}

\section{Estrutura}

Como visão independente, Zc 5,5-11 está construída a partir de diálogos que introduzem os elementos simbólicos que ajudam o leitor a perceber a unidade o tema. A descrição da visão assemelha-se a uma "estrutura teatral" ou "cênica" em ato único, ${ }^{362}$ constituída de prólogo, núcleo, duas cenas e desfecho:

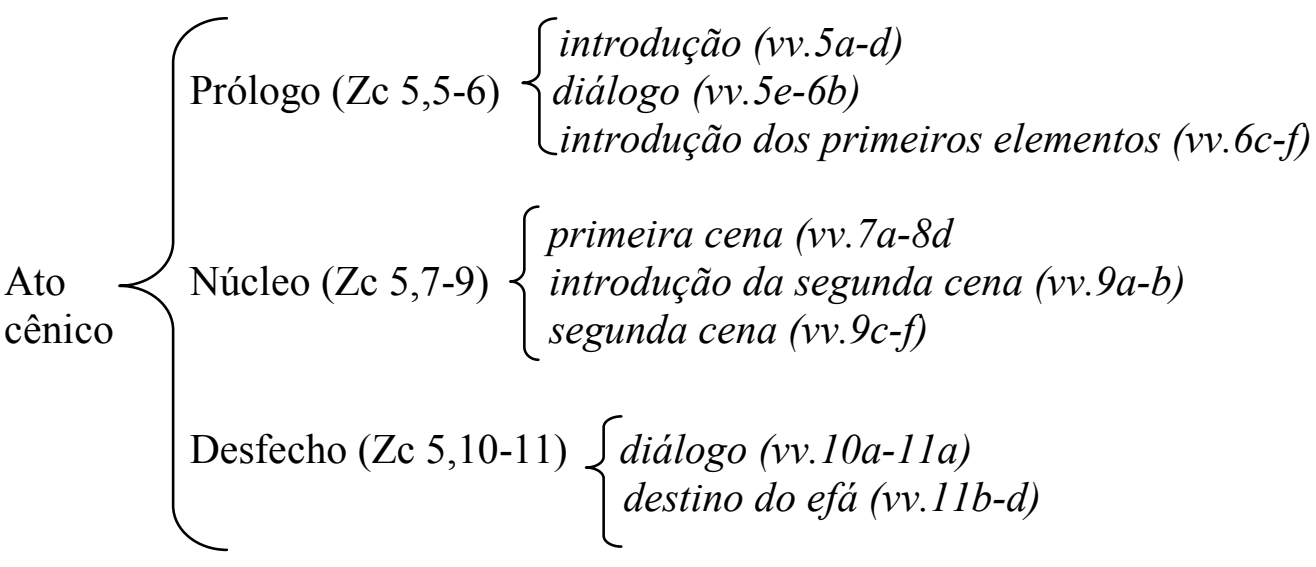

${ }^{360}$ Cf. P. H. KELLEY; D. S. MYNATT; T. G. GRAWFORD, The Masorah of Biblia Hebraica Stuttgartentia. Introduction and Annotated Glossary. Grand Rapids; Michigan: Willian B. Eerdmans Publishing, 1998, p. 155-156.

${ }^{361}$ Segundo C. KÖRTING ("Sach 5,5-11 - Die Unrechtmäßigkeit wird an ihren Ort verwiesen", Bib 87/4 (2006), p. 478-491) e M. HALLASCHKA (Haggai und Sacharja 1-8, p. 242-250), Zc 5,5-11 era, inicialmente, formada pelos versículos 5-6 e 9-11; os sufixos pronominais de primeira pessoa do plural masculino de o "olho" (עין), no v.6f, seriam uma referência aos ladrões e perjuros (Zc 5,1-4), com quem estabeleceu uma relação; a culpa estaria sendo removida de "sobre toda a

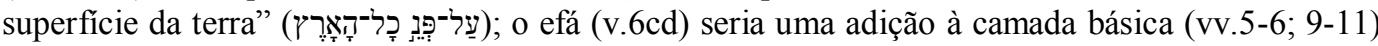
que colocou uma deusa no seu interior (v.7ab) e a identificou com a "iniquidade" (v.8ab), para dramatizar a visão um comentário foi adicionado ao texto fechando o efá e impedindo a fuga da deusa.

${ }^{362}$ Para C. L. MEYERS e E. M. MEYERS (Haggai, Zechariah 1-8, p. 310), Zc 5,5-11 é formada por dois atos: ato I - o efá e seu conteúdo são apresentados (v.5-8); ato II - o efá é removido (v.911); o ato I se desdobra em duas cenas: o efá (v.5-6) e a mulher (v.7-8). 
O prólogo tem a função de pôr em cena o mensageiro de $\mathrm{YHWH}$ em diálogo com o profeta (v.5a) e desvelar os primeiros elementos da visão, o "efá"

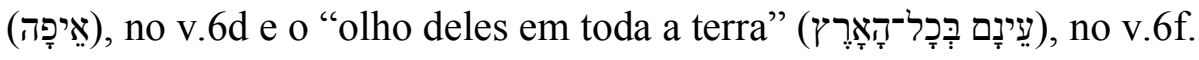

O núcleo é constituído de duas cenas em que, embora tenha a atenção centralizada no efá, introduz novos elementos em cada uma delas. As "rubricas",

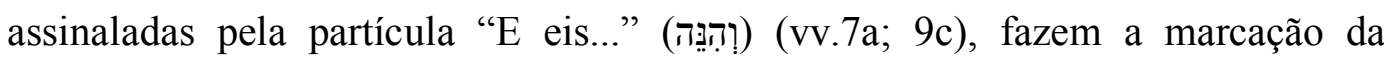
entrada das cenas, separadas por fórmula semelhante à que dá início a algumas visões (cf. Zc 2,1.5; 5,1; 6,1.), uma espécie de "fórmula de revisão" (vv.9ab).

O desfecho apresenta, através de diálogo (vv.10a-11a), um recurso literário que sustenta toda a descrição do destino do efá, sua remoção e os cuidados que serão providenciados para sua instalação (vv.11b-d).

O "ato cênico", assim descrito, pode ser organizado em prólogo, núcleo e desfecho.

\subsection{2.}

\section{Ato cênico}

Zc 5,5-11 é o espaço cênico visual que contém a encenação em ato único onde se desenvolvem o prólogo, o núcleo e o desfecho. O prólogo (vv.5-6) insere os atores: YHWH, o mensageiro e o profeta. O mensageiro e o profeta dialogam enquanto são desvelados os primeiros elementos da visão: o efá e o olho deles em toda a terra.

As cenas do núcleo apresentam-se como "quadros" que acontecem no mesmo lugar e momento, mostrados ao profeta de forma contínua, numa sucessão de imagens em movimento e sem interrupção (vv.7a-8d; 9c-f). Estas cenas são organizadas de modo que as imagens sobressaiam dentro da visão como um todo, acontecendo em um mesmo espaço visual para onde o olhar do profeta deve se dirigir.

O desfecho apresenta o mensageiro descrevendo o destino que será dado ao efá (vv.10-11), sua remoção para Senaar, e as providências que deverão ser tomadas para sua instalação. O conjunto de "quadros" interligados na narrativa da visão profética apresenta o seguinte esquema organizacional: 

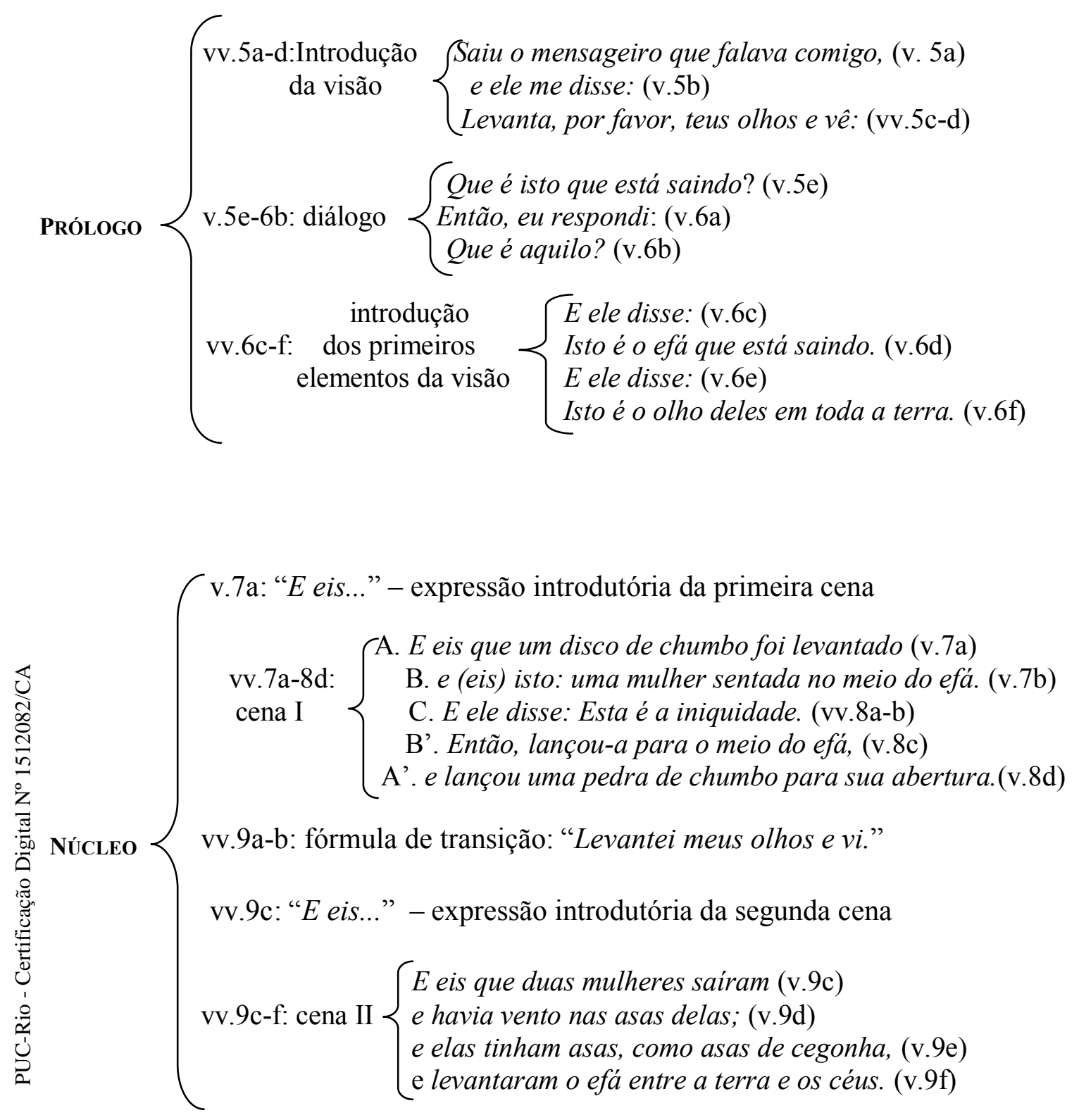

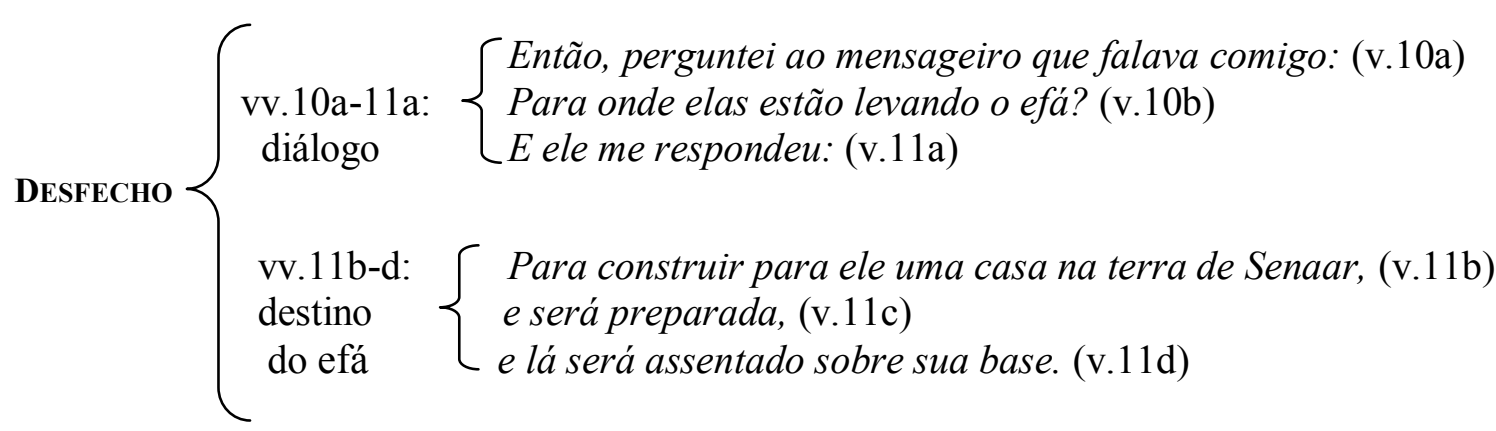




\section{5 .}

\section{Gênero literário}

Zc 5,5-11 apresenta características que parecem inspiradas em narrativas do gênero apocalíptico, uma vez que se utiliza dos elementos comuns para compor uma visão extraordinária: uma mulher sentada dentro do efá, uma vasilha de medir cereais (cf. Zc 5,7b); o efá levantado entre a terra e os céus (cf. Zc 5,9f); duas mulheres com asas de cegonha (cf. Zc 5,9c-e); a revelação comunicada a um destinatário humano por meio de um ser sobrenatural (cf. Zc 5,5a). ${ }^{363}$

Muitas vezes, este "caráter surrealista e mágico" faz com que Zc 1-8 seja considerado um livro "pré-apocalíptico" ou "às portas da apocalíptica". Entretanto, Zc 5,5-11 não deve ser entendido como um texto de característica apocalíptica, pois não se trata de uma visão centrada num mundo sobrenatural, em detrimento da história humana, nem de um juízo futuro de YHWH sobre acontecimentos que culminam em destruição. Os elementos de Zc 5,5-11, a mediação do mensageiro e as explicações sobre o que está sendo visto adequamse ao gênero profético. ${ }^{364}$

A descrição profética valoriza a dimensão intra-histórica com a presença de YHWH reinando soberano e participando da dinâmica da história, em resposta à ambiguidade humana. Nesse sentido, Zc 5,5-11 é expressão do seu contexto histórico e da percepção da necessidade de uma mediação profética, que necessita da ajuda de um mensageiro que revela a vontade divina para Israel.

Zc 5,5-11 "anuncia o fim do modo como as coisas estão ocorrendo e abre possibilidades alternativas a partir do resultado da intervenção de YHWH nas relações humanas". 365 A ausência de um oráculo conclusivo, conforme ocorre algumas vezes no ciclo de visões $(\mathrm{Zc} 1,7-6,15)$, gera diversas interpretações

\footnotetext{
${ }^{363}$ Cf. J .J. COLLINS, “apocalíptica”, In: DCT, p. 161-165.

${ }^{364}$ Cf. M. L. C. LIMA, “Escatologia”, Diccionario del profetismo bíblico, p. 255-266; M. L. C. LIMA, Mensageiros de Deus: profetas e profecias no Antigo Israel. Rio de Janeiro; São Paulo: Editora PUC Rio; Editora Reflexão, 2012, p. 108.

${ }^{365}$ Cf. HILL, A. E., "Zechariah”, p. 114.
} 
como, por exemplo, justiça social ou idolatria, culpa humana e onisciência divina, de acordo com seus símbolos principais: o efá e a mulher. ${ }^{366}$

Como visão, Zc 5,5-11 requer que o leitor esteja pronto para se deparar com uma narrativa de natureza caleidoscópica, ou seja, uma narrativa que vai alterando seu padrão, apresentando recortes e personagens extraordinários de imagem complexa, abstrata e mutante. A narrativa, que não possui um curso normal nem elementos ordinários, revela um mundo que transcende a realidade terrena, passando a mensagem divina e preparando o leitor para uma mudança no curso das ações humanas. Para isso, diante do fascínio da visão, deve-se identificar, no simbolismo das imagens, o contexto social e religioso que permite entrever a realidade teológica presente na história de salvação, observando a narrativa como um todo, e não somente os detalhes. ${ }^{367}$

Zc 5,5-11 apresenta-se como uma profecia em forma de relato de visão que, de forma ostensiva, examina a história e, com base nela, aponta para um tempo futuro no qual o povo será transformado e o convívio social se tornará mais justo. ${ }^{368}$ Nem tudo que o profeta viu se limitou ao seu próprio tempo, seu relato de visão revelou esperanças para o futuro, deixando sob os aspectos social e religioso um legado para as gerações posteriores: YHWH é que detém o sentido último da história humana. ${ }^{369}$

\footnotetext{
${ }^{366}$ Segundo L-S, TIEMEYER(“The Vision Report Genre between Form-Criticism and RedactionCriticism: An Investigation of Amos 7-9 and Zechariah 1-6 in The Book of Twelve and the New Form Criticism". In: M. J. BODA; M. H. FLOYD; C. M. TOFFELRNI [orgs.], Society of Biblical Literature/Ancient Near East Monographs. Atlanta: SBL Press, 2015, p. 96), um texto com oráculo conclusivo terá sempre uma interpretação diferente de outro que não o tenha; um texto com muitos oráculos torna sua interpretação mais fechada, apoiada em contextos históricos específicos; um texto sem oráculo se abre a um universo de interpretações.

${ }^{367}$ Cf. A. E. HILL, "Zechariah", p. 114-115.

${ }^{368}$ Cf. B. O. LONG, "Reports of Visions Among the Prophets". In: JBL, 95/3 (1976), p. 364.

${ }^{369}$ Cf. A. R. PETTERSON, "The Eschatology of Zechariah's Night Visions". In: E. R. HAYES; L-S. TIEMEYER (orgs.), I Lifted my Eyes and Saw, p. 117-134.
} 


\section{Significado teológico de Zc 5,5-11}

Na visão de Zc 5,5-11, o profeta descreve o que viu e o que lhe foi revelado pelo mensageiro, através dos elementos simbólicos, para conhecer e anunciar a vontade de YHWH. Estas imagens precisam ser interpretadas, dandose atenção às interconexões entre estrutura, conteúdo e contexto da visão.

Visando ao melhor entendimento, este comentário foi dividido de acordo com o esquema estabelecido anteriormente na organização do texto em prólogo, núcleo, constituído de duas cenas, e desfecho.

\section{1}

\section{Prólogo (Zc 5,5-6)}

Saiu o mensageiro que falava comigo, $\quad 5 \mathrm{a}$ e ele me disse:

Levanta, por favor, teus olhos e vê:

Que é isto que está saindo? Então, eu respondi:

Que é aquilo?

E ele disse:

Isto é o efá que está saindo.

E ele disse:

Isto é o olho deles em toda a terra.
$5 \mathrm{~b}$

$5 \mathrm{c}$

$5 \mathrm{~d}$

$5 \mathrm{e}$

$6 \mathrm{a}$

$6 \mathrm{~b}$

$6 \mathrm{c}$

$6 \mathrm{~d}$

$6 \mathrm{e}$

$6 f$

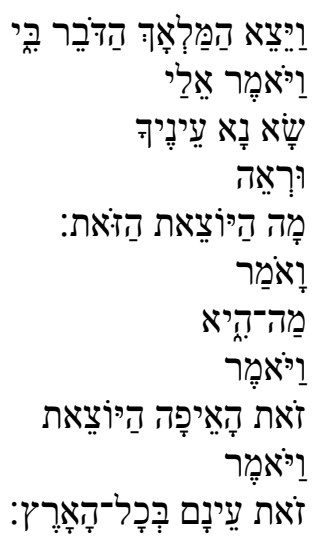

O prólogo (vv.5-6) tem a função de preparar o leitor para receber a mensagem divina. Assim, tendo YHWH como principal agente da cena, apresenta o mensageiro, mediador entre YHWH e o profeta, e os dois primeiros elementos da visão.

Zc 5,5-11 é a única visão do ciclo de visões em que ocorre uma ordem explícita para o profeta levantar os olhos. As imagens são vistas pelo profeta como que "projetadas no céu", sendo aos poucos desveladas e esclarecidas. Este movimento ajuda na percepção dos níveis da descrição no qual Zc 5,5-11 se desenvolve: a) a narrativa apresentada ao profeta (vv.5a-d); b) o diálogo entre o mensageiro e o profeta (vv.5e-6b); c) a visão dos elementos (vv.6c-f). Estes três 
níveis estão interconectados e formam uma estrutura muito bem articulada: introdução da visão, diálogo e introdução dos primeiros elementos. ${ }^{370}$

"Saiu o mensageiro que falava comigo, e ele me disse:

Levanta, por favor, teus olhos e vê:" (vv.5a-d)

A introdução (vv.5a-d) ${ }^{371}$ distingue-se das demais fórmulas de visões por sua estrutura complexa, com utilização do verbo sair" (יצָָ), constituída de duas partes independentes, podendo qualquer uma delas ser omitida, sem que se perca o sentido da narrativa:

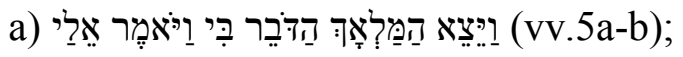

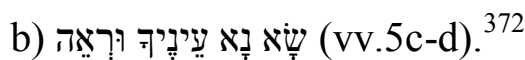

O verbo "sair" (יָָָָ), uma peça chave da narrativa, tem o sentido de "desvelar", de "pôr a descoberto" aquilo que se encontrava oculto, introduzindo a figura do mensageiro em um contexto que inspira mistério. ${ }^{373}$ Assim, este verbo introduz a figura do mensageiro (v.5a); insere-se no diálogo com algo marcado textualmente pelo pronome demonstrativo "isto" (זאת), no v.5e; revela finalmente o efá como primeiro elemento da visão (v.6d).

O verbo "falar" (דָָָרָ), que ocorre como um termo usual no ciclo das visões de Zacarias (cf. Zc 1,1.7; 4,6.8), ${ }^{374}$ é utilizado duas vezes: como um particípio, na introdução (v.5a), e no diálogo final (v.10a). A forma do verbo no particípio ajuda o leitor a vivenciar a visão como algo próximo e atual, assim como auxilia o fluxo dialogal entre o mensageiro e o profeta.

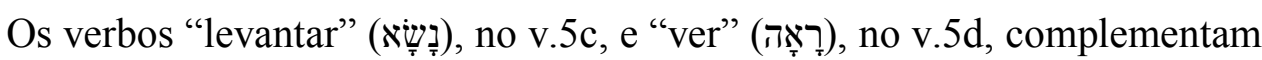
a fórmula introdutória e, utilizados juntos, têm o sentido de uma advertência ou um alerta. A ação conjunta "Levanta, por favor, teus olhos e vê:" (vv.5cd) pode

\footnotetext{
${ }^{370}$ No entendimento de B. O. LONG ("Reports of Visions Among the Prophets", p. 363), "a imagem visionaria é simbólica, algumas vezes bizarra, e há sempre um padrão de diálogo cujo propósito é decifrar seu significado esotérico".

${ }^{371}$ Segundo C. L. MEYERS e E. M. MEYERS (Haggai, Zechariah 1-8, p. lvii), as introduções seguem um mesmo padrão ao longo do ciclo de visões e são consideradas "fórmulas", entendidas como sentença ou expressão que ajuda o leitor a identificar o início de nova visão.

${ }^{372} \mathrm{O}$ ciclo de visões (Zc 1,7-6,8) segue determinado padrão com a fórmula: "Levantei meus olhos e vi" (cf. Zc 2,1; 2,5; 5,1; 6,1).

${ }_{373}$ Cf. H. D. PREUSS, “พญָָ”. In: TDOT, v. VI, p. 225-250.

${ }^{374}$ Cf. também Zc 6,$9 ; 7,1.4 .8 ; 8,1.18$.
} 
estar relacionada com o ato físico de erguer os olhos para algo que se passa acima do nível normal de visão, exigindo concentração temporária dos sentidos em alguma coisa "projetada no céu". ${ }^{375} \mathrm{O}$ uso dos dois verbos no imperativo foi suavizado com a partícula volitiva "por favor" (נָָ), no v.5c, com a função de tornar polida a ordem que se desejava fosse atendida. ${ }^{376}$

\section{"Que é isto que está saindo?}

Então, eu respondi: Que é aquilo?" (vv.5e-6b)

Toda a descrição é sustentada por diálogos, nos quais é desenvolvido um esquema habilidoso de perguntas e respostas. Este tipo de recurso cria o "cenário didático" para que o profeta compreenda a visão. ${ }^{377}$

Com o diálogo imprimindo certa tensão (vv.5e-6b), o mensageiro procura confirmar se o profeta reconhece, de fato, o que está sendo revelado. A pergunta corrobora o interesse do mensageiro para que o profeta perceba o que está "saindo": Que é isto que está saindo? (v.5e). Contudo, o profeta parece não se dar conta da natureza extraordinária do que estava saindo, pois devolve com outra pergunta o que lhe foi perguntado: "Que é aquilo?" (v.6b). Assim se percebe o que está próximo do mensageiro e ainda distante do profeta.

Inicialmente, a atenção se volta para esse algo referido como "isto" (זָאת) (v.5e), pronome demonstrativo feminino singular, que irá concordar com o substantivo feminino singular do elemento que será desvelado a seguir, o "efá"

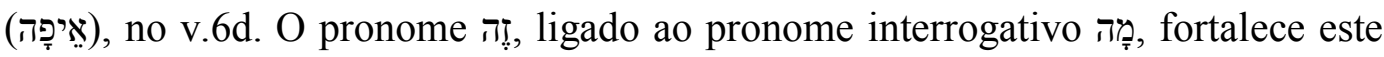
último $^{378}$ e, usado de forma independente, tem o objetivo de fazer com que a atenção se concentre naquele algo determinado: o efá.

Nesse sentido, na estrutura da pergunta "Que é isto que está saindo?"

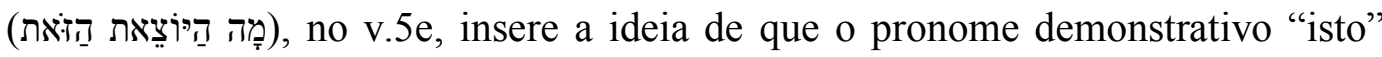
(זنאת) antecipa o que será revelado, o "efá" (איפָה), apontando para sua presença na

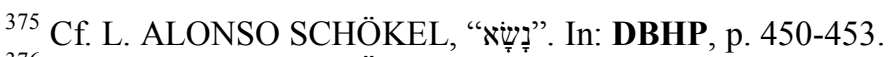

${ }^{376}$ Cf. L. ALONSO SCHÖKEL, "“נְָ". In: DBHP, p. 414.

377 Cf. R. A. WERLINE, "Assessing the Prophetic Vision and Dream Texts for Insights into Religious Experience", p. 1-15.

${ }^{378}$ Para H. WOLF ("זr?". In: DITAT, p. 380-381), mesmo que os exemplos encontrados se concentrem em Noé (cf. Gn 5,29), no Senhor (cf. Is 66,2) ou explicitamente em YHWH (cf. 5,4) é possível adaptar o uso em Zc 5,5-11.
} 
visão desde o início, quando o profeta dá a ordem para o profeta levantar os olhos e ver.

Esta ideia é reforçada pelo uso do artigo, que precede o verbo צִָָָ, no particípio, e o pronome זٓזת, dando objetividade ao elemento visado, o "efá" (אִפָָ), no v.6d. ${ }^{379}$ Assim, o diálogo caminha para levar este elemento para o centro da narrativa, como eixo de ligação da visão que reunirá em si, na ação final, a mensagem definitiva de YHWH.

$\mathrm{Na}$ resposta do profeta ao mensageiro, em forma de pergunta "Que é aquilo?" (מָה־היא), no v.6b, o pronome feminino הִיא foi traduzido por "aquilo" para distingui-lo do pronome זٓאת, traduzido anteriormente por "isto" (v.5e). ${ }^{380} \mathrm{O}$ uso do pronome interrogativo "que" (מָז), nos vv.5e e 6b, ${ }^{381}$ aponta novamente para a imagem já vislumbrada, o efá (v.6d). A estratégia de usar no diálogo um esquema de pergunta e resposta aprimora a visão e confirma a necessidade do discernimento do profeta. ${ }^{382}$

A ênfase na utilização do gênero feminino é, por vezes, considerada uma forma de depreciação da figura da mulher, levando a classificar Zc 5,5-11 como um texto de caráter misógino. ${ }^{383}$ Contudo, o argumento não se sustenta, pois o texto apresenta também um bom uso do gênero masculino, algumas vezes até em condição de discordância de gênero. ${ }^{384}$ A denúncia contra a má conduta da sociedade israelita não estava relacionada somente à mulher, devendo ser estendida para um contexto maior no qual cabem todos os pecados representados simbolicamente na visão do efá.

“E ele disse: Isto é o efá que está saindo” (v.6d)

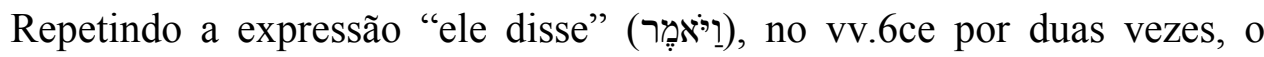
mensageiro põe em cena, um atrás do outro, os dois primeiros elementos da visão,

\footnotetext{
${ }^{379} \mathrm{Cf}$. GBH $\S 35 a ; 137 f$.

${ }^{380}$ Cf. H. WOLF, "Trị". In: DITAT, p. 381.

381 Para F. BROWN, S. R. DRIVER e C. A. BRIGGS (“מָה". In: BDBH. Massachusetts: Hendrickson Publishers Marketing, 2014, p. 552), o uso do pronome interrogativo, normalmente utilizado em interrogações diretas, antes de verbos ou substantivos (cf. Gn 4,10), é também muito frequentemente usado em expressões como na visão (cf. também Gn 15,2; 12,26; 13,14).

382 Cf. R. A. WERLINE, "Assessing the Prophetic Vision and Dream Texts for Insights into Religious Experience", p. 1-15.

${ }^{383}$ Segundo J. SCHNOCKS, “An Ephah Between Earth and Heaven”, p. 255), Zc 5,5-11, Jó 14,14, Lv 15,19-29 e Sl 51,7 são textos de caráter misógino.

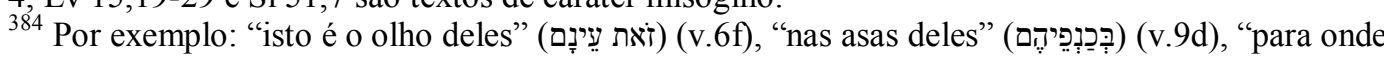

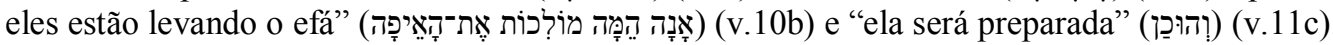


apontando sua intenção de fazer o profeta visualizar, de uma só vez, a cena do “efá" (איפָּה), no v.6d, e o "olho deles" (עינָה), no v.6f.

O primeiro elemento revelado, o "efá" (איפָה), no v.6d, está precedido do artigo definido, indicando que já era algo determinado e conhecido do profeta. De fato, o efá era um vasilhame utilizado no cotidiano da comunidade do antigo Israel como unidade de medida para cereais (grãos e farinhas). Este vasilhame era feito de ramos entrelaçados de material vegetal, como salgueiros, palmeiras, juncos, canas, ${ }^{385}$ mas podia ser de madeira, pedra e o que é mais provável, de cerâmica. $^{386}$

O אֶיפָה era usado em dois contextos do antigo Israel: em locais relacionados com o plantio, colheita e venda de grãos (cf. Dt 25,14; Jz 6,19); ${ }^{387} \mathrm{e}$ em santuários, no transporte e em medidas de ofertas para o culto (cf. Lv 5,11; $6,13[20])^{388}$

O substantivo אָיפָּ pode designar tanto a medida como o próprio recipiente (cf. Jz 6,19; Rt 2,17; 1 Sm 17,17). ${ }^{389}$ Além do efá, outros vocábulos são utilizados pela $\mathrm{BH}$ para designar o uso de medidas de grãos em contexto religioso, como,

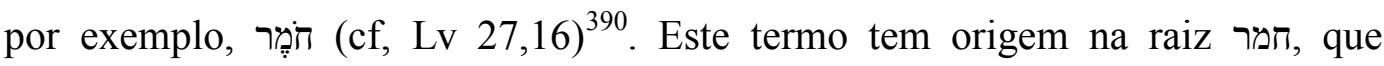
significa o "ato de encher (amontoar) de cereal um recipiente, ou de derramar líquido dentro de um jarro". ${ }^{391}$ Acredita-se que essa origem esteja relacionada à carga suportada por um jumento (cerca de $90 \mathrm{~kg}$ ), por causa de sua semelhança com a palavra "jumento" (חירמוֹ).

Os termos equivalência ao efá. Em Ezequiel, o אִיפָ e o correspondem, cada um, a um

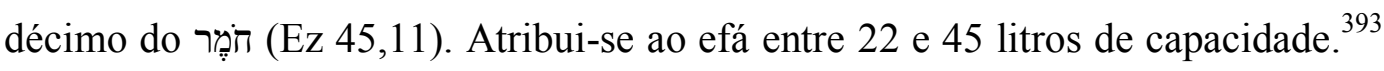
Contudo, nenhum jarro foi encontrado em escavações em pedaços suficientes que

\footnotetext{
${ }^{385}$ Cf. A. E. HILL, "Zechariah", p. 166.

${ }^{386}$ Cf. J. B. SCOTT, “אֵיפָה”. In: DITAT, p. 62.

${ }^{387}$ Cf. também 1Sm 17,17; Is 5,10; Am 8,5; Mq 6,10; Rt 2,17.

${ }^{388}$ Cf. também Nm 5,15; 28,5; Ez 45,13.24; 46,5.7.11.14.

${ }^{389}$ Cf. J. B. SCOTT, "אַיפָ". In: DITAT, p. 62.

${ }^{390}$ Cf. também Nm 11,32; Ez 45,11.13.14.

${ }^{391}$ Cf. G. H. LIVINGSTON, “מֶָר". In: DITAT, p. 488.

${ }^{392}$ Cf. M. J. BODA, The Book of Zechariah, p. 343.

${ }^{393}$ Segundo C. L. MEYERS e E. M. MEYERS (Haggai, Zechariah 1-8, p. 295-297), com base na reconstrução de fragmentos de vasos feita por Albright do material extraído no sítio Teill Beit Mirsim, R. B. Y. Scott concluiu que se o efá for o mesmo que um "תַּ", teria capacidade de 22 litros; W. Nowack (in Lehrbuch der Hebräischen Archäologie, 1894) estimou em 36,44 litros.
} 
permitissem uma reconstrução para que se possa afirmar a capacidade exata de um efá. 394

Utilizado em ofertas do sábado (cf. Nm 28,9), em situações peculiares da vida (cf. Nm 5,15) e em transações comerciais (cf. Dt 25,16), o efá ${ }^{395}$ tornou-se símbolo de injustiça provocada pelas medições adulteradas, denunciada pelos profetas preocupados com a ética e o bem-estar social (cf. Am 8,5; Mq 6,10).

Como o vasilhame era utilizado para medir uma quantidade convencionada, como da cevada colhida (cf. Rt 2,17), da farinha para o sacrifício (cf. Lv 5,11), ou simplesmente do grão seco (cf. 1Sm 17,17), se seu tamanho fosse alterado, alterava-se também o conteúdo. A denúncia dos profetas podia estar associada tanto ao tamanho da vasilha como ao seu conteúdo. A fraude praticada significava a exploração dos mais pobres da comunidade, que não podiam se defender das classes dominantes no comércio (cf. Ez 45,10; Mq 6,10). ${ }^{396}$

A lei deuteronômica aponta para a preocupação com medições íntegras e justas, exigindo que o povo se mantivesse fiel às práticas comerciais honestas (cf. Dt 25,13-16). Havia, portanto, prática de ações incompatíveis com a posição de Israel como o povo de YHWH. O efá na visão é um alerta para que se reelabore o relacionamento estabelecido com YHWH por intermédio da lei. ${ }^{397}$

Apesar do conhecimento que se tinha do efá, tanto como objeto utilizado na medição de grãos, como símbolo da injustiça praticada na comunidade, uma interpretação antiga relaciona o "efá" (אֵיפָה) em Zc 5,5-11 aos zigurates, uma arquitetura típica da Babilônia e de regiões que sofreram sua influência. ${ }^{398} \mathrm{O}$ argumento é que, nesta visão, o termo "אֵיפָּ" não designa a vasilha de medição, mas, por influência de palavras mesopotâmicas, seria um pequeno santuário. ${ }^{399}$ Este termo teria relação com uma palavra suméria para os zigurates, com sentido

\footnotetext{
394 Cf. J. B. SCOTT, “אֵיפָה". In: DITAT, p. 62.

${ }^{395}$ Cf. Dt 25,14; Pr 20,10; Ez 45,10-11.

${ }^{396}$ Cf. A. E. HILL, "Zechariah", p. 166.

${ }^{397}$ Cf. L. J. HOPPE, "Deuteronômio", Comentário bíblico, p. 187.209-210.

${ }^{398}$ Para S. MARENOF ("Note Concerning the Meaning of the Word "Ephah", Zechariah 5:5-11", p. 264-267), o efá (אָיפָה) representa o zigurate de Lagash, em honra à divindade feminina NinGirsu, que tinha o nome de E-pa, cujo significado é "casa do cume".

399 Segundo S. MARENOF ("Note Concerning The Meaning of the Word 'Ephah', Zechariah, 5:511 ", p. 264-267), a palavra efá teria a mesma raiz que os substantivos assírios $A-p u$ ("gruta") e $A$ batw ("sala") e o árabe 'Afta ("sala"). Mais tarde, esta raiz deu origem ao verbo Apu, em assírio, com o sentido de "construir". Também os substantivos hebraicos "casa" ou "templo" (הָיכָ), "casa"

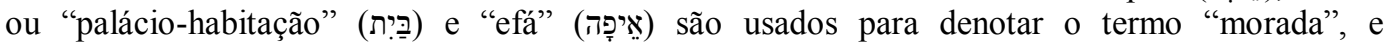
classificados como originados dos verbos de vogal média com sentido de "conter" ou "reter".
} 
de "casa da cúpula"; no hebraico "הָיָָ", "casa" ou "templo", 400 mesmo sentido

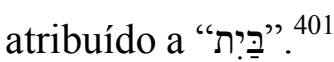

Estes templos ou santuários, localizados na parte superior dos zigurates eram chamados de "casas visíveis" ou "casa para serem vistas". Assim, estabelece-se também uma relação do "efá" (איפָּ), no v.6d, com o elemento

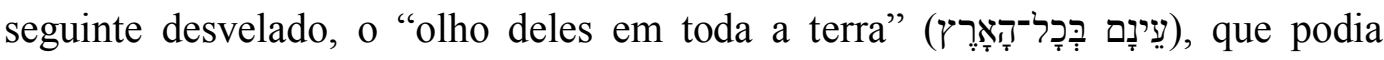
significar o "olho" (עַין) voltando-se para o efá, o "templo". 402

O voltar-se para "olhar" proporcionaria a visibilidade do efá e ratificaria a repetição da expressão "E ele disse" (vv.6ce), que teria o sentido de apresentar um segundo fato sobre o efá (v.6f). Este segundo fato estaria relacionado com o conteúdo, a mulher sentada em seu interior (v.7b), que seria uma deusa e, portanto, uma representação da iniquidade (v.8b). ${ }^{403}$

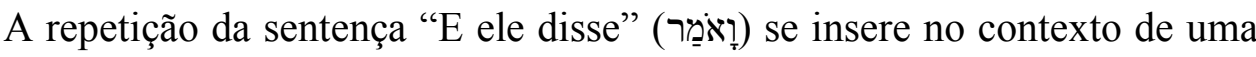
descrição que contém elementos de uma visão profética com imagens extraordinárias. Essa repetição faz parte do processo de apreensão e compreensão da visão pelo profeta, cuja mensagem é decorrente de sua formação cultural, que o preparou para a experiência e lhe forneceu um modelo para descrever a visão.

A habilidade de o profeta apresentar os dois primeiros elementos, um após

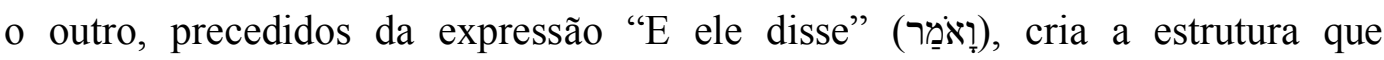
transforma os elementos desvelados em gatilhos experienciais, permitindo que sejam analisados não apenas como símbolos ou metáforas da visão, mas como revelações divinas. ${ }^{404}$ É possível que tenha havido um erro em se concluir que o “efá" (איפָָה) seria uma leitura de é.pa para é.gidru, na língua suméria, cujo significado seria de um pequeno santuário.

A possibilidade que mais se aproximaria seria e.pa.pah, que significa "casa" ou "cela" do deus Anu e da deusa Ishtar da Babilônia, contudo, a mudança de é.pa.pah para efá é questionável. Na época em que essa análise foi feita não

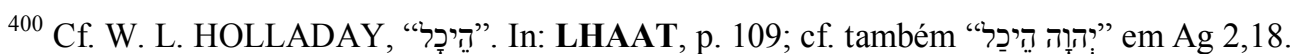

${ }^{401}$ Cf. W. L. HOLLADAY, "בָּיָּית". In: LHAAT, p. 52-53.

${ }^{402}$ Para W. RUDOLPH (Haggai - Sacharja 1-8 - Sacharja 9-14 - Maleachi, p. 118-121), "olho deles" (עָנ) a "aparência deles" ou "aspecto deles", contudo, este entendimento não produz um sentido aproveitável no contexto da visão.

${ }^{403}$ C. L. MEYERS e E. M. MEYERS (Haggai, Zechariah 1-8, p. 297) supõem alternativamente que o sufixo de "עֵינָס" possa ser uma referência ao efá, embora, em hebraico, o sufixo seja masculino plura, e o efá uma palavra feminina; a mulher representaria a idolatria que deve ser removida para Senaar.

${ }^{404}$ Cf. R. A. WERLINE, “Assessing the Prophetic Vision and Dream Texts for Insights into Religious Experience”, p. 1-15.
} 
havia bons dicionários para as línguas acadia e sumérica. ${ }^{405}$ Sabe-se agora que o termo "איפָּה" deriva de fonte egípcia ('êpâ), atribuído também a vasilhame usado para medir. ${ }^{406}$

Além disso, esta antiga interpretação do efá como um santuário pagão e, analogamente, a mulher como uma deusa desse culto, se configuraria uma grande ironia, uma vez que o efá era uma vasilha utilizada como medida de grãos para levar oferta para o culto no Templo e, neste caso, estaria transportando uma deusa de um culto pagão ao Templo de YHWH (cf. Lv 5,11; 6,13[20]) ${ }^{407}$.

O uso do efá é bem atestado no Antigo Testamento, são trinta citações, dezessete sem artigo (cf. Jz 8,18; Rt 2,19; 1Sm 19,22) ${ }^{408}$ e treze com artigo (cf. Ex 16,36; $\mathrm{Nm} \mathrm{5,15;28,3).}{ }^{409}$ Algumas referem-se a textos proféticos e legais (cf. Lv 19,36; Dt 25,14.15 [duas ocorrências]; Ez 45,10; Am 8,5; Mq 6,10; Pr 20,10 [duas ocorrências]), outras denotam indicações de grandeza ou definições de medida. ${ }^{410}$ Em Zc 5,5-11 é mencionado cinco vezes, sempre precedido de artigo definido (vv.6d.7b.8c.9f.10b), apontando para a importância deste elemento na visão. ${ }^{411}$

Assim, em conformidade com o uso atestado no Antigo Testamento e o contexto social e religioso da narrativa, o significado do efá está relacionado com a falsificação de medida denunciada pelos profetas. As transações ilícitas prejudicavam enormemente os pobres no pós-exílio, tornando-os ainda mais pobres, levando-os à condição de escravos.

Houve no pós-exílio uma forte tendência à diferenciação social, com aumento da pobreza nas camadas inferiores da escala social. ${ }^{412}$ Sobre essa situação parece refletir o profeta Ageu quando menciona o desequilíbrio entre salários e preços, embora não mencione as causas da discrepância (cf. Ag

\footnotetext{
${ }^{405}$ Assim conclui M. J. BODA (The Book of Zechariah, p. 342-343, n. 70) sobre a interpretação de S. MARENOF ("Note Concerning The Meaning of the Word "Ephah", Zechariah, 5:5-11", p. 264-267.

${ }^{406}$ Cf. R. FULLER, “אָיפָה". In: NDITEAT, p. 373-378.

407 Cf. também Nm 5,15; 28,5; Ez 45,13.24; 46,5.7.11.14.

408 Cf. também 2Sm 9,4; Jó 38,4; Pr 20,10; Is 5,10; 49,21; Jr 3,2; 36,19; Ez 45,24; 46,5.11; Am 8,5 .

${ }^{409}$ Cf. também Ez 45,11 (duas vezes); 45,13 (duas vezes); 46,14; Zc 5,6.7.8.9.10 (cinco vezes).

${ }^{410}$ Cf. J. SCHNOCKS, “An Ephah Between Earth and Heaven”, p. 258.

${ }^{411}$ Cf. GHG, 2006, § 126 q.; cf. também P. JOÜON; T. MURAOKA, GHG, $\S 35$ a; ibid. $\S 137 f$.

412 Cf. J. BRIGHT, A History of Israel, p. 365-366; R. KESSLER, História social do antigo Israel, p. 184.
} 
1,1.6). ${ }^{413}$ De acordo com a tradição profética, a imagem do efá refere-se concretamente a uma acusação de abusos no uso de medidas (cf. Am 8,5). ${ }^{414}$

A importância do efá é tão grande que ele inicia (v.6d), permanece citado (vv.7b.8c.9f) e termina o relato da visão (cf. 10b), tornando-se o eixo de todo o mal da comunidade, que precisa ser removido. "De concreto está sendo acusado o abuso de medidas". ${ }^{415} \mathrm{O}$ efá representa a falta de ética nas relações e males sociais provocados por exploradores dos assalariados (cf. Lv 19,13; Dt 24,14-15), da viúva e do órfão (cf. Zc 7,10), e pelos que tentam obter vantagens pessoais ou lesar o outro (cf. Mq 6,10; Am 8,5). Os que perpetram o mal não temem YHWH (cf. Ml 3,5). ${ }^{416}$

"E ele disse: Isto é o olho deles em toda a terra." (vv.6e-f)

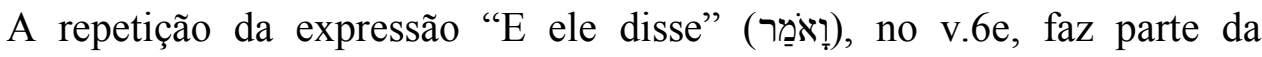
habilidade do profeta, que a utiliza no seu método didático para fazer o leitor apreender mais um elemento presente na cena da visão, o "olho deles em toda a

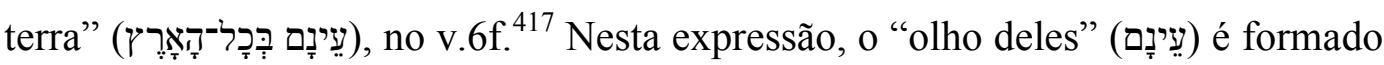

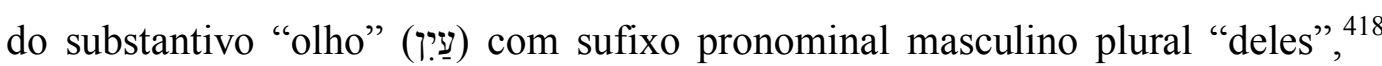

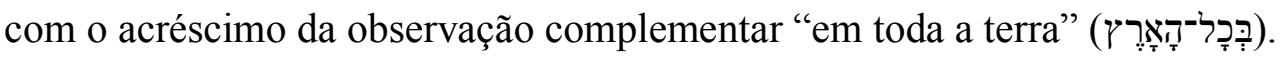

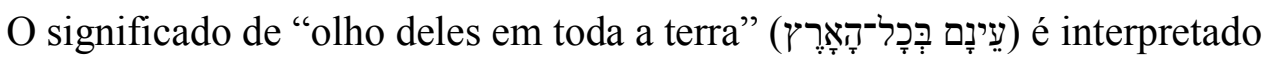
como: a) a iniquidade, ${ }^{419}$ b) um "olho" que se volta para olhar, ou seja, "aparência" ou "visibilidade" da essência daquilo que se mostra como ilícito, o culto idolátrico; c) um "olho mau que tudo vê"; d) o olho de YHWH, em

\footnotetext{
${ }^{413}$ Cf. C. L. Meyers; E. M. Meyers, Haggai, Zechariah 1-8, p. 27.

${ }^{414}$ Cf. C. KÖRTING, "Sach 5,5-11 - Die Unrechtmäßigkeit wird an ihren Ort verwiesen", p. 245.

${ }^{415}$ Cf. M. HALLASCHKA, Haggai und Sacharja 1-8, p. 242-250; cf. também C. KÖRTING, "Sach 5,5-11 - Die Unrechtmäßigkeit wird an ihren Ort verwiesen", p. 478-491.

${ }^{416}$ Cf. também Lv 29,36; Dt 25,14-15; Pr 20,10.

${ }^{417}$ Cf. R. A. WERLINE, "Assessing the Prophetic Vision and Dream Texts for Insights into Religious Experience", p. 1-15.

${ }^{418}$ Uma cópia do Manuscrito da LXX e a versão siríaca trazem "a iniquidade dele" ( $\dot{\eta} \alpha \dot{\alpha} \delta$ เкía

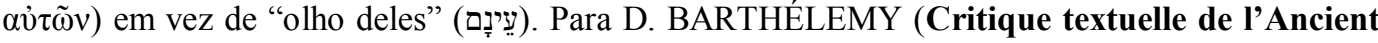
Testament III, Tome 3, Ezéchiel, Daniel e les 12 Prophètes. Göttingen: Editions Universitaires Fribourg Suisse, Vandenhoeck \& Ruprecht, 1992, p. 958) o TM faz sentido e "o efá polariza os olhos de todos".

${ }_{419}$ Para J. G. BALDWIN (Ageu, Zacarias e Malaquias, p. 103-104) esta é a melhor interpretação para o termo "עָינָים".
} 
referência aos "sete olhos que percorrem toda a terra" (cf. Zc 4,1-5), ${ }^{420}$ d) um "olho hostil". 421

Há quem pense que a melhor interpretação para o "olho deles" (עינָׁ) seria

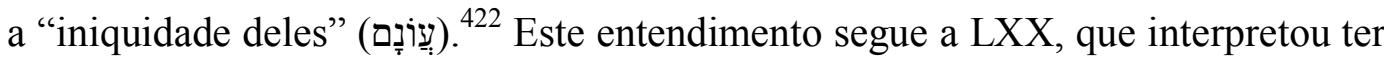
havido um erro do escriba, que confundiu as formas semelhantes do waw e do yod; ou que a vocalização do $\mathrm{M}^{\mathrm{L}}$ considerou que textos originalmente idênticos careciam de mater lectionis. ${ }^{423}$

Além de a LXX ter alterado fundamentalmente o sentido do texto, não se pode afirmar que seja um reflexo da leitura hebraica original ou que o $M^{L}$ apresentasse corrupção. $\mathrm{O} \mathrm{M}^{\mathrm{L}}$, que recebeu o apoio da Vulgata, é compreensível e, também como já foi dito, a lição mais difícil é, provavelmente, a mais antiga. ${ }^{424}$

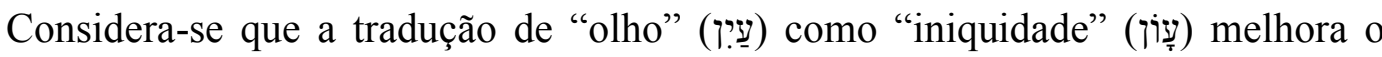
sentido da visão porque estabelece logo a relação destes elementos com o efá (v.6d), condenado como medida injusta em transações comerciais (cf. Am 8,5); ${ }^{425}$ ou por práticas idolátricas, quando o efá é considerado um templo pagão; ${ }^{426} \mathrm{ou}$ pelo pecado de ladrões e perjuros em Zc 5,1-4. ${ }^{427}$

Não há fundamento para relacionar o "olho deles" com medida injusta, templo ou idolatria, e depois relacioná-lo com a visibilidade do efá. Não há nenhuma referência à visibilidade ou aparência do efá em nenhum lugar da Bíblia, nem de um efá confeccionado como templo para um deus estrangeiro. Nesta interpretação, até se poderia admitir que houvesse um grupo a quem este efátemplo estaria destinado, pois "deles" poderia ser uma referência aos grupos que praticavam idolatria, mas a expressão restante, "em toda a terra", que tem um

\footnotetext{
${ }^{420}$ Para M. H. FLOYD ("The Evil in the Ephah, p. 54-59), há uma relação entre as visões precedentes, Zc 4,1-14 e Zc 5,1-4 e Zc 5,5-11; as três apresentam objetos símbolos do culto: o candelabro, os recipientes dourados do azeite e as lâmpadas (Zc 4,1-14); o rolo (Zc 5,1-4) e o efá (Zc 5,5-11). Na visão, estes objetos possuem dimensões discrepantes, saem e ficam visíveis; são objetos que ocupam lugar de honra no templo, e fazem parte da relação do homem com o santuário.

${ }^{421}$ Cf. M. J. BODA, The Book of Zechariah, p. 344.

${ }^{422}$ Essa é a justificativa de J. G. BALDWIN (Ageu, Zacarias e Malaquias, p. 103-104) para interpretar "o olho deles sobre toda a terra" como "iniquidade".

${ }^{423}$ Cf. M. J. BODA, The Book of Zechariah, p. 344.

${ }^{424}$ Segundo M. H. FLOYD ("The Evil in the Ephah", p. 55, n. 4), a maioria dos estudiosos prefere a leitura da LXX, enquanto uma minoria mantém o TM.

${ }^{425}$ Para J. G. BALDWIN (Ageu, Zacarias e Malaquias, p. 103-104), é melhor interpretar o "olho deles" como "iniquidade deles" por causa da facilidade de se substituir a consoante waw pela yod. ${ }^{426}$ Cf. R. HANHART, "Dodekapropheton 7.1: Sacharja 1-8, p. 364-365.

${ }^{427}$ Cf. M. HALLASCHKA, Haggai und Sacharja 1-8, p. 242-250; C. KÖRTING, "Sach 5,5-11 Die Unrechtmäßigkeit wird an ihren Ort verwiesen", p. 478-491.
} 
caráter universal não encontraria explicação, pois a profecia de Zacarias se destina ao povo de Israel. ${ }^{428}$

Tenta-se também relacionar "olho deles em toda a terra" (עינָם בְּכָל־דָהָרָץ), no v.6f, com o "efá", no v.6d, mesmo com o sentido literal de medida enganosa, transferindo-se a relação depois para a "mulher" (v.7b) e a "iniquidade" (v.8b). ${ }^{429}$ Esta ideia é baseada no sufixo pronominal de "olho deles" (עינָם) no masculino plural, como referência àqueles que roubam e enganam, diminuindo a medida do

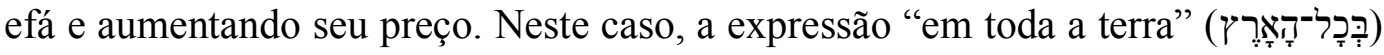
refere-se aos que devem ser punidos pelo mal praticado. ${ }^{430}$

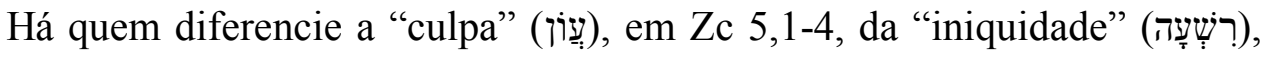
em Zc 5,5-11, ao ligar a visão antecedente à estudada. Para quem pensa assim, a culpa e a iniquidade do povo de Israel são removidas para Senaar. Amplia-se a visão indevidamente, pois são visões independentes, com elementos diferentes, a primeira com uma maldição e a segunda com a remoção. As duas visões devem ser examinadas individualmente, cada uma em seu contexto literário, históricosocial e religioso. ${ }^{431}$

O substantivo "olho" (עַין (עין) é utilizado em sentido literal e em expressões relacionadas a "vista", sinônimo da expressão "diante dos olhos" ou "na presença". Também é empregado em expressões com o sentido de estados mentais ou emocionais. Com o construto, indica "abominação aos olhos" (cf. Ez 20,7). ${ }^{432}$ A exemplo de Ezequiel, Zacarias questiona o comportamento do povo de Israel, mas não como pecado de idolatria, e sim quanto ao desejo de riqueza e poder, como recompensa por espionar os irmãos para o Império Persa. ${ }^{433}$

Assim, uma boa interpretação para este elemento da visão, à luz do contexto literário e histórico-social, seria pensar o "olho deles" como o "olho" que

\footnotetext{
${ }^{428}$ Segundo J. SCHNOCKS (“An Ephah between Earth and Heaven”, p. 258), Rabbi Solomon ben Isaac é conhecido pela tradição judaica pelo acróstico Rashi.

${ }^{429}$ J. SCHNOCKS (“An Ephah between Earth and Heaven”, p. 259) entende que no pensameno de Rashi a ideia de que o efá tem o sentido de uma medida enganosa é tão forte que ele a transfere para a mulher afirmando: "Esta mulher, que você vê dentro da efa, é uma medida na forma da iniquidade praticada pelos iníquos. E eis que agora eles são forçados em suas entranhas, a fim de serem punidos dentro do próprio mar, dentro do qual eles mediram - medida contra medida".

${ }^{430}$ Cf. J. SCHNOCKS, “An Ephah between Earth and Heaven”, p. 252-270.

${ }^{431}$ Assim interpretam M. HALLASCHKA (Haggai und Sacharja 1-8, p. 242-250) e C. KÖRTING ("Sach 5,5-11 - Die Unrechtmäßigkeit wird an ihren Ort verwiesen", p. 478-491).

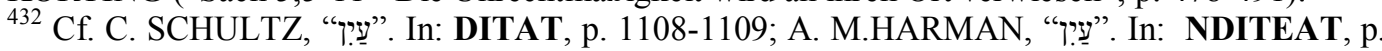
390-396.

${ }^{433}$ Cf. T. CRAVEN, "Ezequiel”, Comentário bíblico, p. 76-78; L. J. McGREGOR, "Ezequiel”.
} CBVN, p. 1096-1097. 
vigiava o povo de Jerusalém para o Império Persa, em referência aos que se encarregavam de espionar o que acontecia na comunidade, principalmente em relação à arrecadação de impostos (cf. Jr 5,21.26-28.31ab). ${ }^{434}$ Esta hipótese se estende aos funcionários do império ("olho do rei”), encarregados de verificar a lealdade dos súditos, evitando possíveis sublevações contra a ordem estabelecida. ${ }^{435}$

A dificuldade em definir o grupo correspondente ao sufixo do termo composto, "olho deles" (עָינָם), encontra justificativas na tentativa de discernir seu significado, que afirmam ser: a) um sufixo objetivo e não possessivo, indicando o objeto da ação vista, implícito ao substantivo עַ ("o olho deles [que vê])"; um genitivo objetivo ("Este é o olho (de YHWH) que os vê em todos os lugares"); ${ }^{437}$ c) uma referência aos que retornaram a Jerusalém; ${ }^{438}$ d) uma referência aos ladrões e perjuros da visão anterior (cf. Zc 5,1-4); ${ }^{439}$ e) uma terminação adverbial ou mesmo uma ênclise, e não um sufixo. ${ }^{440}$

A imagem do sufixo de simbolizando um coletivo, não é rara na Bíblia (cf. Gn15,15; Nm 16,3), ${ }^{441}$ e aqui é usada como referência aos grupos que, levados pela avareza, tiravam vantagem da situação posicionando-se ao lado do poder conquistador que oprimia o pobre. ${ }^{442}$

Com a reforma financeira de Dario I, que organizou um novo sistema monetário, o povo de Judá passou a pagar os impostos pré-fixados pelo Império Persa em moedas de prata e não mais através de produtos. Para garantir a arrecadação, o império mantinha um "oficial financeiro" que trabalhava sob as ordens diretas do rei. Para um controle ainda mais eficaz, havia o "olheiro do rei"

\footnotetext{
${ }^{434}$ Cf. C. SCHULTZ, “עַיע." In: DITAT, p. 1108-1109.

${ }^{435}$ Cf. A. H. J. GUNNEWEG, História de Israel, p. 222.

${ }^{436}$ M. J. BODA (The Book of Zechariah, p. 344) entende o sufixo como objetivo e não possessivo, em referência à aparência do efá, uma representação do zigurate, santuário pagão da Mesopotâmia; C. L. MEYERS e E. M. MEYERS (Haggai, Zechariah 1-8, p. 298) concordam com Boda, apenas como uma possiblidade.

437 Para M. H. FLOYD ("The evil in the ephah", p. 59), este pode ser o caminho correto da interpretação.

${ }^{438}$ Cf. M. H. FLOYD, "The Evil in the Ephah", p. 55.

${ }^{439}$ Deve-se ter cautela em relacionar Zc 5,1-4 a Zc 5,5-11, como o faz M. H .FLOYD ("The evil in the ephah", p. 53-56), para que estas visões não sejam entendidas como continuidade uma da outra; são narrativas independentes, com elementos, conteúdos e desfechos próprios: em Zc 5,1-4, os transgressores são amaldiçoados e punidos; em Zc 5,5-11 os elementos, imagens simbólicas das transgressões da comunidade, são enviados para Senaar.

${ }^{440}$ Para C. L. MEYERS e E. M. MEYERS (Haggai, Zechariah 1-8, p. 298) é outra possibilidade.

${ }^{441}$ Cf. Gn 15,13; Nm 16,3; 1Sm 2,8; Sf 2,7.

${ }^{442}$ Cf. C. SCHULTZ, "עַיפיר". In: DITAT, p. 1108-1109.
} 
(o "ouvido do rei" ou o "mensageiro do rei") que se encarregava de fazer uma inspeção cuidadosa em cada província. ${ }^{443}$

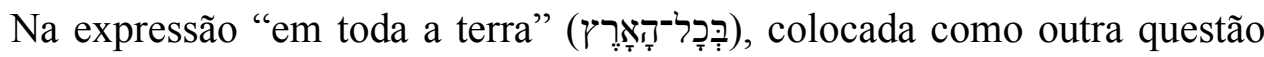
além do sufixo representativo de um coletivo, o substantivo "terra" (צֶרץ faz referência a Judá, ${ }^{444}$ considerada como Jerusalém e arredores, ${ }^{445}$ o que daria sentido à interpretação de o "olho deles" (עֵינָם) como o olho daqueles encarregados de espionar para o Império Persa, o que acontecia na comunidade. Este sentido pode se estender para as comunidades da diáspora ou até mesmo para um ponto de vista universal, considerado todo o território de domínio persa. ${ }^{446}$

O uso de "terra" (אֶרץ), logo após "olho deles" (עָינָם), representa retoricamente os efeitos resultantes da relação do homem com YHWH e com o próximo (cf. Os 4,3; Jó 31,38). ${ }^{447}$ A ruptura da relação provocada pelo pecado tem como consequência a anulação da aliança com YHWH (cf. Dt 28,15-17), fazendo com que a maldição se manifeste na "terra" (cf. Zc 5,1-4), ${ }^{448}$ e os seres humanos sejam dispersos e confusos pela "terra" (cf. Gn 11,1-9). ${ }^{449}$

\section{2.}

\section{Núcleo (Zc 5,7-9)}

\subsubsection{Cena I (vv.7a-8d)}

E eis que um disco de chumbo foi $7 \mathrm{a}$

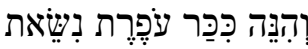
levantado e (eis) isto, uma mulher sentada no meio $7 \mathrm{~b}$

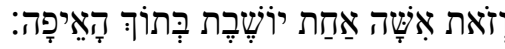
do efá.

E disse:

Esta é a iniquidade.

$8 b$

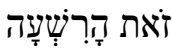

Então, ele lançou-a para o meio do efá, $\quad 8 \mathrm{c}$ e ele lançou uma pedra de chumbo para $8 \mathrm{~d}$

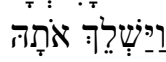
sua abertura.

\footnotetext{
${ }^{443}$ Cf. A. T. OLMSTEAD, History of the Persian Empire, p. 59

${ }^{444}$ Cf. M. H. FLOYD, "The Evil in the Ephah", p.56.

${ }^{445}$ Cf. C. L. MEYERS; E. M. MEYERS, Haggai, Zechariah 1-8, p. 298.

${ }^{446}$ Cf. M. H. FLOYD, "The Evil in the Ephah", p. 55; M. J. BODA, The Book of Zechariah, p. 343.

${ }^{447}$ Cf. C. J. H. WRIGHT, "אֶרץ". In: NDITEAT, v. 1, p. 505-511.

${ }^{448}$ Para M. M. PAZDAN ("Zacarias", p. 162), “terra”, em Zc 5,1-4, refere-se ao problema especial de usurpação de terras pelos que permaneceram em Judá, durante o exílio na Babilônia.

${ }^{449}$ Cf. C. J. H. WRIGHT, "אֶר?". In: NDITEAT, v. 1, p. 505-511.
} 
A primeira cena do núcleo possui a estrutura de quiasmo, fazendo

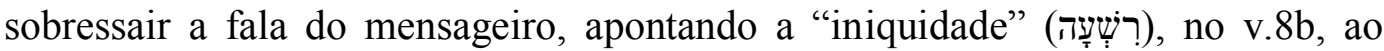

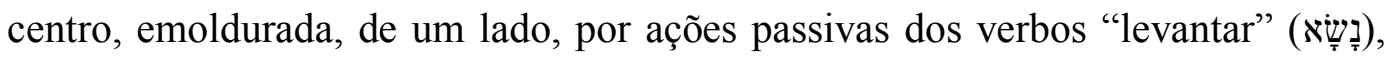
no v.7a, e "sentar" (יְָָּ ), no v.7b, e de outro por ações ativas no hifil do verbo

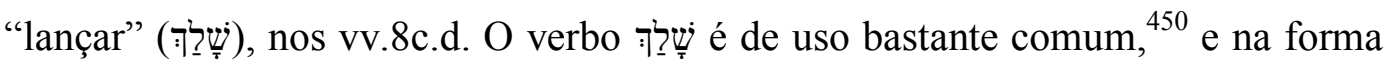
hifil enfatiza o rigor com que a ação foi executada. ${ }^{451}$ Desta forma, o quiasmo apresenta claramente a mensagem divina:

A. E eis que um disco de chumbo foi levantado (v.7a)

B. e (eis) isto: uma mulher sentada no meio do efá. (v.7b)

C. E ele disse: Esta é a iniquidade. (vv.8a-b)

B'. Então,ele lançou-a para o meio do efá (v.8c)

A'. E ele lançou uma pedra de chumbo para sua abertura (v.8d)

As figuras dentro do quiasmo se cruzam e se entrelaçam para revelar um jogo de palavras, ideias e ações que transformam a narrativa da visão em algo plástico e dinâmico. As duplas menções ao efá se contrapõem simetricamente, e em paralelo, na figura literária (vv.7b.8c), fazendo o efá permanecer, materialmente, como uma espécie de eixo sobre qual todos os outros elementos se ligam diretamente. ${ }^{452}$

"E eis que um disco de chumbo foi levantado

E (eis) isto: uma mulher sentada no meio do efá." (vv.7a-b)

A oração, traduzida literalmente como "e isto: uma mulher sentada no meio do efá" (v.7b), apesar de gramaticalmente correta e subordinada à oração anterior "E eis que um disco de chumbo foi levantado." (v.7a), pode parecer solta no texto e sem sentido. Uma vez que o segundo verso parece depender sintaticamente do termo "eis" (הִּנה), a oração foi traduzida por: "e (eis) isto: uma mulher sentada no meio do efá." (v.7b).

\footnotetext{
${ }^{450}$ Cf. Gn 37,20.22.24; Ex 1,22; Js 8,29; 10,27; $2 \mathrm{Sm} 18,17 ; 2 \mathrm{Cr} 25,12 ;$ Jr 38,6.9.

${ }^{451}$ Cf. M. J. BODA, The Book of Zechariah, p. 349.

${ }^{452} \mathrm{O}$ Targum coloca o efá no centro do quiasmo de forma mais direta: " $E$ disse: Por causa disso (da medida falsa), eles eram iníquos" (v. 8a-b), e, no versículo seguinte, acrescenta: "Então, foram para o exilio porque usaram medida falsa." (v.8c). A mulher dentro do efá, que poderia causar estranheza, não é mencionada, foi ignorada completamente (cf. H. BUNCE, "Translation and Interpretation: Targum and Septuagint in Zechariah 5:5-11”, p. 53-65).
} 


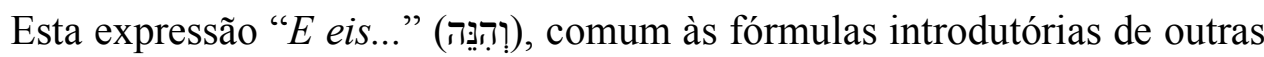
visões do ciclo de visões do profeta Zacarias (cf. Zc 1,8; 2,1; 2,5; 5,1; 6,1), oferece uma descrição da cena vista pelo profeta (vv.7ab). Nela, o verbo "levantar" (נָָָָָ), no v.7a, no nifal (reflexivo) não deixa saber quem levantou o objeto que encobria o efá e seu conteúdo. Teria sido o mensageiro? Ou a mulher em seu interior? É provável que não tenha sido o profeta, que aparentemente atuava como um espectador descrevendo os acontecimentos: "E eis que um disco de chumbo foi levantado" (v.7a), com imagem imediatamente desvelada. (v.7b).

O termo "disco" (רכִכִּ), em hebraico, remete a um objeto de formato

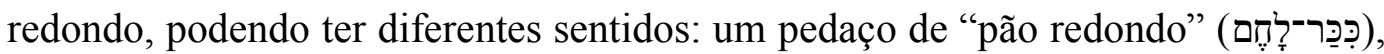
em $1 \mathrm{Sm}$ 2,36; um disco como unidade de peso ou valor, um "talento de prata"

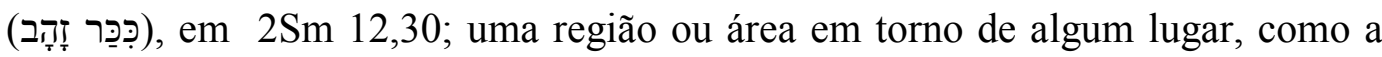
região "em torno do rio Jordão", em Gn 13,10s; uma moeda, como o "talento" (ככַּּ), em Ex 25,39. ${ }^{453}$

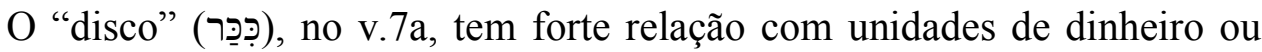
moeda de troca, que eram originalmente pesos. Inicialmente, essas unidades de dinheiro eram "barras de ouro ou prata", os "pesos". O sentido evoluiu para um substantivo coletivo de pesos menores, colocados juntos (cf. Ex 38,25), ${ }^{454}$ usados como moeda no comércio na troca de mercadorias mensuráveis (alimentos ou animais). Mais tarde, por necessidade e comodidade, se estabeleceu o uso de metais de diferentes formas, trabalhados de acordo com a qualidade e o peso para determinar o valor de troca. ${ }^{455}$

Estes pesos podiam ser uma moeda persa de ouro ou prata, de cerca de oito gramas e meio, ou talvez o de um dracma, uma moeda grega. $\mathrm{O}$ "peso" ( ) era realmente um peso de forma redonda, como indica seu nome, e unidade de dinheiro do mundo antigo (cf. Ex 25,39; 37,24). Havia pesos de diversos valores, o bega' era metade de um siclo (cf. Ex 38, 25-27) e o talento era equivalente a 3000 ciclos. Com base nisso, avalia-se que o talento teria entre 33 e $39 \mathrm{~kg}$, o siclo, entre 11 e 13 g e o bega' entre 5,5 e 6,5 g. Outra unidade de dinheiro, a mina,

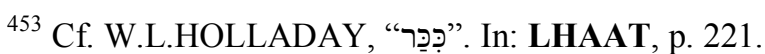

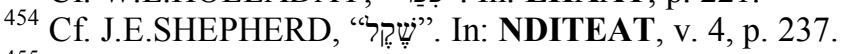

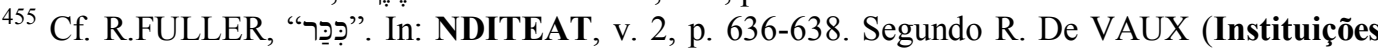
de Israel no Antigo Testamento, p. 245-246), os pagamentos de tributos com metais eram feitos em grande quantidade (cf. 2Rs 15,19; 18,14); as transações individuais, com estrangeiros (cf. Gn $42,25.35 ; 43,12$ s; $1 \mathrm{Sm} \mathrm{13,21;1Rs} \mathrm{10,29),} \mathrm{e} \mathrm{em} \mathrm{compra} \mathrm{de} \mathrm{terras} \mathrm{(cf.} \mathrm{Gn} \mathrm{23,14s;} \mathrm{2Sm} \mathrm{24,24;} \mathrm{1Rs}$ $16,24 ; 21,2 ; \mathrm{Jr} 32,9)$ eram em pequena quantidade.
} 
mostra a estranha forma de calcular seu valor como 60 siclos ("a vossa mina será 20 ciclos +25 siclos +15 siclos), indicando a existência de pesos de 15,20 e 25 siclos (cf. Ez 45,12). Estas unidade eram encontradas também em outras regiões próximas de Israel, como Mesopotâmia e Ugarit. ${ }^{456}$

A utilização do termo "disco" (כְכְַ) em Zc 5,5-11, que tem também o sentido de "cobertura", ${ }^{457}$ aponta para a ironia do profeta que associa este objeto ao efá, conhecido como símbolo da injustiça cometida em transações comerciais, conforme denunciado por profetas (cf. Am 8,5; Mq 6,10). Esta associação se estende para o uso do termo "chumbo" (עָפֶָרת) na expressão "disco de chumbo" no v.7a, que remete tambem a valor comercial. O chumbo, material de que é feito o disco na visão, é um material familiar ao povo do antigo Israel: a) no êxodo, quando os egípcios afundaram "como chumbo nas águas grandiosas" (Ex $15,10) ;{ }^{458}$ b) no elogio a Salomão é dito: "multiplicaste a prata como o chumbo" (Eclo 47,18); ${ }^{459}$ c) no retorno dos filhos de Israel para Moab, Moisés recomenda que o chumbo e outros metais dos despojos dos madianitas, eliminados por eles, passem pelo fogo para purificação (cf. Nm 31,22) $;{ }^{460}$ d) Jó, estando perto da morte, deseja que sua proclamação de inocência seja talhada na pedra "com cinzel de ferro e chumbo para sempre" (Jo 19,24). ${ }^{461}$

Embora Israel não produzisse chumbo, havia ricos depósitos da substância ao norte, na Síria, e na Ásia Menor. ${ }^{462}$ O chumbo e o estanho eram materiais conhecidos em Israel, que utilizava principalmente o segundo, buscado em Tarsis, para a fabricação de bronze (cf. Ez 27,12). Numa lista de metais resistentes ao

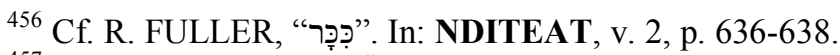

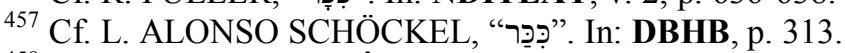

458 J. F. CRAGHAN ("Êxodo", p. 104-105), lembra que YHWH é a salvação, o poder e a misericórdia para com seu povo.

${ }^{459}$ Em Jerusalém a prata é tão comum como as pedras [cf. 1Rs 10,27]. Substitui-se o "chumbo", metal mais barato, por "pedras", provavelmente porque a pedra era usada como "peso" no mundo antigo [cf. Pr 16,11] (cf. Bible Encyclopedias Cyclopedia of Biblical, Theological and Ecclesiastical Literature. In: <https://www.studylight.org/encyclopedias/mse/l/lead.html, 7/11/2017>; acesso: 25 abr. 2019).

${ }^{460}$ Para H. K. MAINELLI ("Números". In D. BERGANT; R. J. KARRIS (orgs.), Comentário bíblico, v. 1, p. 145-185), como tudo que entra em contato com um cadáver se torna impuro, os despojos de guerra resistentes ao fogo, que serão repartidos entre combatentes, povo, sacerdotes e levitas, devem ser purificados no fogo e na água lustral (cf. Nm 31,19-24).

${ }^{461}$ Cf. J. L. McKENZIE, “chumbo”. In: Dicionário Bíblico. São Paulo: Paulus, 1978, p.151.

${ }^{461}$ M. J. BODA (The Book of Zechariah, p. 347) entende como uma provável referência à prática de esculpir inscrições sobre pedra e derramar chumbo derretido nas cavidades das letras, para torná-las legíveis e ao mesmo tempo preservá-las da ação do tempo.

${ }^{462}$ Cf. M. J. BODA, The Book of Zechariah, p. 347.
} 
fogo (cf. Nm 31,22), ou facilitadores de escambo (cf. Ez 27,12), o chumbo, aparece sempre no final dela, apontando para seu baixo valor. ${ }^{463}$

O povo de Israel detinha conhecimento de metalurgia (cf. Ez 22,18.20) e a escolha deste material certamente estava ligada à remoção segura do mal da comunidade de Judá. É possível que a intenção no uso do metal fosse mostrar que o mal (a "escória") ficaria definitivamente preso por um material impenetrável, que utiliza o "fogo" na sua purificação. O objeto de chumbo lançado sobre a abertura do efá se configura uma grande ironia, pois se trata de um metal que só se valoriza depois de separado das escórias do material extraído da terra, ou seja, após sua purificação (cf. Jr 6,28; cf. também Jr 1,25).

O verbo "levantar" (נָָָ), no v.7a, indica a ação que fará com que o conteúdo do efá seja revelado. Este verbo sugere, como o efá e o disco, transações relacionadas com dinheiro, pois tem o sentido de "emprestar", "ser credor de um penhor", ou ainda "conceder um empréstimo com penhor". ${ }^{464} \mathrm{O}$ uso deste verbo estaria, portanto, de acordo com a preocupação de YHWH com os pobres para que não fossem vítimas de práticas exploratórias por parte dos poderosos e ricos (cf. Ex 22,25). No antigo Israel, era proibida a cobrança de juros, a não ser de estrangeiros (cf. Ex 22,24-26; Dt 23,20; Lv 25,35-38), mas era permitido fazer empréstimo com tomada de penhor, garantia da dívida, que poderia ser a terra onde o devedor trabalhava e de onde extraía seu sustento, ou um membro da família (esposa, filhos e o próprio devedor), que se tornaria escravo do credor (cf. Ex 21,7; Lv 25,47-55).

A lei, no entanto, procurava proteger a vida doméstica e a dignidade do devedor, limitando a imposição de regras rígidas ou práticas abusivas de cobrança (cf. Dt 24,10-13; Ex 22,26-27) ou mitigando a prática da escravidão por dívidas, através do ano Sabático e das leis de Jubileu que exigiam perdão das dívidas e emancipação do escravo no sétimo e no quinquagésimo ano, respectivamente (cf. Lv 25,39-43; Dt 15,12-18).

Uma narrativa em que os chefes da comunidade do retorno são acusados de estarem concedendo empréstimos cobrando juros (cf. Ne 5,6-13) reforça a ideia de que os elementos da visão (efá, disco, chumbo), ligados a transações comerciais, seriam uma denúncia de injustiças sociais. Se esta prática ocorria no

\footnotetext{
${ }^{463}$ Cf. M. DELCOR, “La vision de la femme dans l'épha de Zach.”, p. 142.

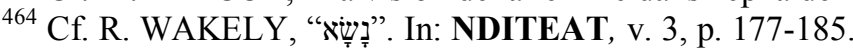


tempo de Neemias, supõe-se que no início do pós-exílio, em que os retornados tentavam se reorganizar, reconstruindo a cidade e o Templo, a situação, provavelmente, saiu de controle. ${ }^{465}$

A pergunta deveria ser sobre a relação entre empréstimo com penhor (נָשָׁ) e a mulher sentada no meio do efá (v.7b). Se todos os elementos até o momento revelados (o olho deles, o efá, o disco e o chumbo) têm uma forte conotação de transação comercial ou financeira, é de se supor que a mulher também esteja relacionada com o tema.

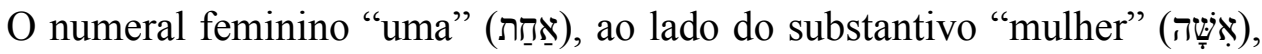
assume a função de adjetivo e pode ter o sentido de "uma só", ou "única", como algo especial. O emprego deste numeral ressalta a solidão da representação feminina no efá (cf. Ecl 4,9-11) e a singularidade da punição (cf. Ez 7,5). Para o antigo Israel, a solidão se configurava em algo terrível (cf. Ecl 4,9-11). ${ }^{466}$

O adjetivo "uma" aponta para a ideia de uma mulher comum da comunidade e não para um panteão de deuses ou uma deusa específica que, em geral, é nomeada como uma deusa mesopotâmica, a Istar da Babilônia, ${ }^{467}$ ou uma deusa do Levante, como Astarte, ${ }^{468}$ ou Aschera. ${ }^{469}$

Deve-se ter cautela com essa interpretação, pois o texto em si não dá nenhuma orientação no sentido de se tratar de uma deusa. A deusa Astarte é apontada como a mulher no efá por causa de uma das estatuetas das coleções encontradas na escavação em Hauran, em um santuário, em posição sentada, com as mãos espalmadas sobre os joelhos. ${ }^{470}$

No entanto, na visão, a mulher está apenas sentada e não há qualquer referência à posição de suas mãos e joelhos. Além disso, como já mencionado acima, nenhum texto bíblico, explícita ou implicitamente, menciona o efá como um templo ou lugar de culto. ${ }^{471}$

\footnotetext{
${ }^{465}$ Cf. Bíblia de Jerusalém, Jr 6,28, p. 1377, notas "b" e "c".

${ }^{466}$ Cf. P. P. JENSON, "אַח". In: NDITEAT, v. 1, p. 339-341.

${ }^{467}$ Cf. K. GALLING, "Die Exilswende in der Sicht des Propheten Sacharja”, p. 30.

${ }^{468}$ Para M. DELCOR ("La vision de la femme dans l'épha de Zach.”, p. 144), por exemplo, tratase da deusa Astarte.

469 Cf. C. FREVEL, Aschera und der Ausschlielichkeitsanspruch YHWHs, Beiträge zu literarischen, p. 523-530.

${ }^{470}$ Segundo S. MARENOF ("Note concerning the Meaning of the Word 'Ephah"”, p. 266), não há dúvidas que a estatueta representa a deusa Astarte, pois as escavações do professor Kellner, em Hauran, demonstram que esta deusa foi cultuada de forma generalizada na Palestina e vizinhanças.

${ }^{471}$ Cf. C. L. MEYERS; E. M. MEYERS, Haggai, Zechariah 1-8, p. 295.
} 


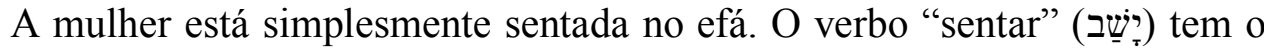
sentido literal de "sentar-se", e também de "permanecer" ou "habitar" um lugar, região, terra, cidade, ou mesmo o mundo (cf. Jz 8,29; 1Rs 7,8; Gn 1,26-27). O conceito de "habitar" num lugar específico pode derivar da ideia do ato de sentarse, como sinal da intenção de permanecer, o que ocorre em situações de hospitalidade em que o convite é feito com intenção de que a visitação se estenda. $^{472}$

A "mulher" (הִ̣), no v.7b, parece confortável em meio à situação dinamizada pelo efá, mas está submetida, pressionada pelo poder de grupos da comunidade judaica pós-exílica (cf. Ml 2,10-16). ${ }^{473}$ Ela é a mulher que habita em Israel, é filha, irmã, esposa, estrangeira ou não, mãe, viúva. Portanto, inserida no contexto do retorno do exílio da Babilônia, a figura de "uma mulher no efá", deve ser analisada sob diversos papéis, como por exemplo, as mulheres que, no préexílio, praticavam necromancia ou adivinhação (cf. 1Sm 28,7). ${ }^{474}$

Com a exclusão dos cultos estrangeiros no exílio e no pós-exílio, as mulheres, responsáveis pelo culto doméstico a YHWH, hábeis em técnicas de exorcismo e de cura (cf. 1Sm 28), e competentes no trato com espíritos e demônios (cf. Lv 20,27), podem ter sido vistas com desconfiança pelos homens, concorrentes em assuntos religiosos. Deuteronômio rejeita as profissões mágicas (cf. Dt 18,10-11) por serem incompatíveis com o culto a YHWH, e quatro pelo menos eram exercidas por mulheres: "magia" (da raiz כֹּּ

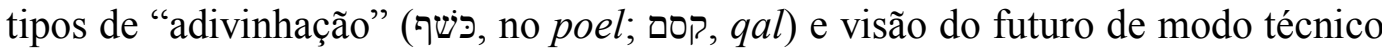

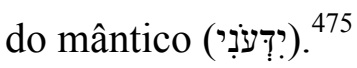

No exílio, Ezequiel condenava as falsas profetizas por continuarem a praticar magias ou idolatrias em troca de dinheiro (cf. Ez 13,17-23). ${ }^{476}$ Trito Isaías adverte contra a idolatria que continuava acontecendo no meio do povo (Is $65,3 \mathrm{~b}$ 4). O culto aos mortos do tempo dos reis (Dt 18,9-13) perseverou no pós-exílio, e

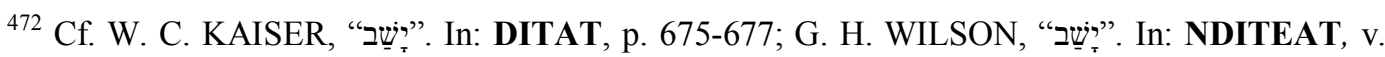
2, p. 549-550.

${ }_{473}$ Cf. também Esd 9,1-2.12; 10,2-3.10.14; Ne 10,31; 13,23-27.

${ }^{474}$ Cf. M. M. PAZDAN, "Zacarias", p. 155-167.

${ }^{475}$ Cf. E. S. GERSTENBERHER, Israel no tempo dos persas, p. 448-449; cf. Ex 22,17; Lv 20,27; Ez 13,23; 1Sm 28,3.9; 2Rs 9,22; 23,24; Is 8,19.

${ }_{476}$ Segundo E. S. GERSTENBERHER (Israel no tempo dos persas, p. 449), as mulheres praticavam adivinhação e magia no templo recém-construído.
} 
as camadas populares mais baixas tendiam constantemente para a apostasia, deixando-se levar pela influência persa (cf. Zc 13). ${ }^{477}$

Os cultos aos mortos, praticados no tempo dos reis (Dt 18,9-13), continuaram no pós-exílio. Escavações arqueológicas ao redor do monte do Templo e dos muros de Neemias mostram que Judá nunca perdeu contato com as regiões vizinhas, o que permitiu que se alimentasse de todo tipo de fonte cultural, arcaicas e contemporâneas, no período persa. ${ }^{478}$

Não se tem clareza do funcionamento destas práticas, sabe-se, porém, que as falsas profetizas ou feiticeiras seduziam e controlavam as vítimas, provocando atos de injustiças (cf. Ez 13,18-19). ${ }^{479}$ As práticas possuíam diversas técnicas com o objetivo de determinar a vontade divina. Era do conhecimento de todos em Israel que estas adivinhações eram consideradas ofensas graves a YHWH (cf. Lv 19,31; Dt 18,11,19-20). Mesmo assim, as técnicas de adivinhação, influenciadas pelo Antigo Oriente Próximo em geral, em particular pela Mesopotâmia, eram bastante populares no antigo Israel. ${ }^{480}$

Com a exclusividade do culto a YHWH, foram proibidos os cultos domésticos, sem dúvida uma proibição dirigida às mulheres, tidas como mais vulneráveis e sujeitas à apostasia. Assim, profetizar seria mais um dos papéis femininos que causavam incômodos dentro da comunidade, que tentava se reestruturar em torno do Templo e da observância da lei.

Outra questão, envolvendo as mulheres da comunidade, diz respeito ao divórcio, condenado por Malaquias como uma prática difundida no pós-exílio (cf. Ml 2,10-16). Embora no texto a palavra hebraica usada signifique "repúdio", sabe-se que foi modificada para que se harmonizasse com a lei que permitia o divórcio. ${ }^{481} \mathrm{E}$, como o profeta Malaquias atuou entre os ministérios de Ageu e Zacarias, ${ }^{482}$ próximo do ano 500 a.C., tudo faz supor que tal prática acontecia também no tempo de de Zacarias. ${ }^{483}$

\footnotetext{
${ }^{477}$ Cf. E. S. GERSTENBERHER, Israel no tempo dos persas, p. 129.

${ }^{478}$ Cf. E. S. GERSTENBERHER, Israel no tempo dos persas, p. 126-128.

${ }^{479}$ Cf. T. CRAVEN, "Ezequiel”, Comentário bíblico, p. 67-87.

${ }^{480}$ L. J. HOPPE ("Deuteronômio", Comentário bíblico, p. 202-203) lembra que algumas destas técnicas são mencionadas em Dt 18,10-11.

481 Cf. D. KIDNER, Esdras e Neemias, p. 74-78.109-111.144-145; M. M. PAZDAN, "Malaquias", p. 176-181.

${ }^{482}$ Cf. J. G. BALDWIN, Ageu, Zacarias e Malaquias, p. 176-178; R. MASON, The Books of Haggai, Zechariah and Malachi, p. 137-139.

${ }^{483}$ Cf. A. E. HILL, “Zechariah”, p. 279.
} 
A advertência de Malaquias é sobre a infidelidade dos maridos, ressaltando a importância da vida familiar (cf. Ml 2,10-16). As mulheres não podiam pedir o divórcio, mas é possível que isso estivesse acontecendo por causa da presença de esposas estrangeiras. A colônia de Elefantina, por exemplo, que sofrera influência estrangeira, admitia o divórcio solicitado por mulher. ${ }^{484}$

No pós-exílio estava havendo uma tendência generalizada de desrespeito às promessas e acordos de todo tipo, nos negócios, no casamento e no relacionamento social (cf. Is 24,16). ${ }^{485}$ Os casamentos mistos não sofriam objeções em termos raciais (cf. Ex 12,38.48; Nm 9,14; Rt 1,16), mas Malaquias os condenava por causa de conflitos religiosos e da questão da propriedade (cf. Ml $2,10-16){ }^{486}$

Em relação à religião, a condenação se dava porque o cônjuge judeu, influenciado pela religião do cônjuge pagão, cedia e abandonava a fé em YHWH (cf. 1Rs 11,1-8; 16,31; Ne 13,23-27). Isto se tornava um problema para a comunidade, pois com o casamento inter-racial, mães não judias se responsabilizavam pela educação dos filhos, o que incluía uma religião estranha a Israel. A apostasia levara o povo ao exílio e naquele momento estava se tornando um hábito que minava a vida espiritual de Israel. ${ }^{487}$

Em relação às propriedades, o casamento misto trazia grandes preocupações. A primeira era em relação às esposas judias, porque os exilados ricos desposavam mulheres estrangeiras para obter melhor posição na sociedade, e abandonavam suas mulheres, conforme dá a entender o profeta Malaquias. A segunda eram as condições de miséria em Judá após o exílio, que tornavam atraentes a satisfatória condição econômica da esposa estrangeira e o dote oferecido aos noivos (cf. Ne 6,18; 13,28). E, embora fosse permitido o divórcio em Israel apenas em condições especiais (cf. Dt 24,1-4), na prática estava se tornando rotina, com mudanças no processo de separação decorrentes das diferentes culturas envolvidas no casamento misto. ${ }^{488}$

\footnotetext{
${ }^{484}$ Cf. L. A. FERNANDES, Evangelização e família: subsídio bíblico, teológico e pastoral. São Paulo: Paulinas, 2015, p. 131-138.

${ }^{485}$ Cf. J. G. BALDWIN, Ageu, Zacarias e Malaquias, p.198-202.

486 Cf. D. KIDNER, Esdras e Neemias, p. 74-78.109-111.144-145; M. M. PAZDAN, "Malaquias", p. 176-181.

${ }^{487}$ Cf. H. G. M. WILLIAMSON, "Esdras e Neemias". In: D. A. CARSON; R. T. FRANCE; J. A. MOTYER; G. J. WENHAM, CBNV. São Paulo: Vida Nova, p. 640-671.

${ }^{488}$ Assim pensa T. C. ESKENAZI (cf. "Out from the Shadows: Biblical Women in the Postexilic Era”, p. 23-43).
} 
Em Israel, o casamento era uma aliança testemunhada por YHWH (cf. Gn 31,50; Pr 2,17), enquanto a lei de Hamurabi decretava que era um contrato legal, feito através de documentos apropriados. Em caso de divórcio, este código estabelecia uma compensação para a esposa, criando um custo para o processo. Assim, pode-se pensar que as mulheres judias do pós-exílio tenham adiquirido também privilégios e obrigações semelhantes às de Elefantina. Se assim foi, conforme o costume local, o esposo autor do pedido de divórcio em Judá não

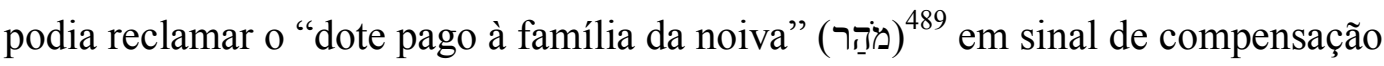
(cf. Gn 34,12; Ex 22,16; 1Sm 18,25). ${ }^{490}$

Com o obscuro período de domínio persa, os textos bíblicos são importantes documentos para se compreender o "papel social" da mulher neste contexto. Sabe-se que homens e mulheres desempenham papéis sociais que apontam para o perfil de cada um em cada momento da sociedade. A vida em grupo pressupõe expectativas de comportamento entre indivíduos, na família e na sociedade, e em momento de mudança e transformação social, pode-se supor que tenha havido prejuízo para a mulher. ${ }^{491}$

Como atuava a mulher numa sociedade que tentava se reorganizar e criar uma nova identidade? Em que sentido incomodava os grupos que tentavam organizar a comunidade judaica em torno da lei e da aliança?

O modelo de vida no antigo Israel era o patriarcal e a família constituída como se fosse uma "casa", onde conviviam esposa, filhos, esposas dos filhos, servos, residentes estrangeiros e viúvas e órfãos sob proteção do chefe da família (cf. Gn 7,1.7; Jz 11,1-7). O termo "casa" ainda abarcava grupos bastante numerosos (cf. 1Cr 5,15.24) que se confundiam com clã (cf. Jz 18,11).

Com a passagem para uma vida sedentária, esta situação modificou-se e o desenvolvimento urbano introduziu transformações sociais que afetaram a organização familiar. ${ }^{492}$ Tais mudanças cresceram por ocasião dos exílios a que foi submetido o povo de Israel, contudo as "grandezas sociais uma vez desenvolvidas não desaparecem, mas continuam a ser desenvolvidas e com isso

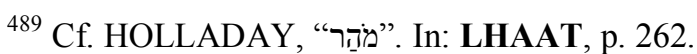

${ }^{490}$ Cf. T. C. ESKENAZI, "Out From the Shadows: Biblical Women in the Postexilic Era", p. $23-$ 43.

${ }^{491}$ Cf. A. GIDDENS, Sociologia. Lisboa: Fundação Calouste Gulbenkian, 2001, p. 42-43.

${ }^{492}$ Cf. R. de VAUX, Instituições de Israel no Antigo Testamento, p. 44-45.
} 
também transformadas". ${ }^{493}$ O antigo modelo, provavelmente, ainda sugere a tutela constante da mulher ao longo de sua vida pelo homem, primeiro pelo pai, eventualmente pelo irmão, e depois pelo marido (cf. Dt 21,18-21). ${ }^{494}$

Nesse sentido, é possível que houvesse grupos interessados em voltar à situação anterior para controlar os acontecimentos e, sobretudo, o patrimônio, ameaçado com a emergência de maior liberdade da mulher no pós-exílio. Mas terá a mulher da comunidade judaica do pós-exílio se submetido? Se a feminilidade e a masculinidade, no sentido de comportamento e identidade, são uma construção cultural, fruto da sociedade, é possível que a mulher tenha assumido outros papéis, resultado do enfrentamento de novas situações e dos quais não pretendia abrir mão. ${ }^{495}$

Os problemas provocados pelo envio do povo de Israel para outras terras, e de outros povos para Judá, durante os exílios a que foram submetidos, não terminaram com o retorno da Babilônia. Primeiro, tiveram que enfrentar a realidade de que nem todos na província de Judá eram judeus e nem todos os judeus retornaram. Segundo, precisaram resolver a questão da posse das terras, cobrada pelos retornados que alegavam ser titulares das propriedades ocupadas pelos remanescentes. Finalmente, precisaram enfrentar duras questões que afetaram diretamente a mulher da comunidade judaica: miséria e endividamento da população, o que tornava os filhos escravos, trazendo consequências nefastas para a vida familiar e transformações estruturais das famílias. Estas famílias, após dois exílios, tinham vivido "no meio das nações", e agora buscavam, através do mecanismo das listas genealógicas e da proibição de casamentos mistos, uma identificação de pertença à "casa de Israel” (cf. Rt 4,17-22). O resultado foi um corpus legislativo concebido, parte na realidade, parte no imaginário, projetado para trás com base na aliança, entre YHWH e o povo, e na lei divina, para conceder a Israel uma identidade. ${ }^{496}$

Todos estes fatores repercutiram no papel da mulher na sociedade judaica provincial no período persa. É provável que o modelo de comportamento da

\footnotetext{
${ }^{493}$ Cf. P. R . KESSLER, História social do antigo Israel, p. 173.

${ }^{494}$ Cf. R. de VAUX, Instituições de Israel no Antigo Testamento, p. 44-45.

${ }^{495}$ Cf. T. C. ESKENAZI, "Out From the Shadows Biblical Women in the Postexilic Era", p. 2343.

${ }^{496}$ Cf. R. ALBERTZ, Historia de la religión de Israel em tiempos del Antiguo Testamento, $p$. 567-588; M. LIVERANI, Para além da Bíblia, história antiga de Israel, p. 309-318.413-434; R. KESSLER, História social do antigo Israel, p. 173-184; E. S. GERSTEMBERGER, Israel no tempo dos persas, p. 114-128.
} 
mulher de uma comunidade estável e circunscrita a um só povo antes do exílio, e depois dispersa e misturada a estrangeiros, não atendesse à nova comunidade que buscava reorganizar-se, obrigada a ajustar-se às novas condições.

Atualizações podem ser observadas nas narrativas bíblicas da época, nas leis, nas relações familiares e sociais e na regularização de bens e propriedades, subjacente à discussão dos matrimônios mistos (cf. Dt 25,7-10; Rt 1,1-4,22). Destinado a viver, a amar e superar o ódio, o homem do antigo Israel, não podia deixar de fazer atualizações, pois, "a vida pedia que pelo menos um vizinho ou um amigo o guiasse e estivesse ao seu redor depois da sua morte, para fazer memória de seu nome". 497

Havia, de fato, uma ordem com posições estabelecidas para as mulheres no pós-exílio, de modo que elas foram colocadas sob suspeição (cf. Lv 12-15) e consideradas suscetíveis à apostasia e à desobediência (cf. Dt 13,7; 1Rs 11,1-5. Contudo o número de julgamentos e condenações (cf. Ez 13, 17-23) e de relatos de mulheres que conseguiram arrancar para si o próprio destino, como por exemplo Rute (cf. Rt 4,1-4), apontam para uma situação mais flexível da mulher na sociedade, o que, certamente, desagradou aos que procuravam ligá-la ao mal na comunidade. $^{498}$

Sobre esse protagonismo feminino, há um certo silêncio e um exemplo é a lista de recenseamento em que, na relação dos filhos de sacerdotes, consta certo Berzelai que se casara com uma das filhas de um galaadita, de quem adotou o nome (cf. Esd 2,61). Tal desvio de padrão comportamental pode ter ocorrido porque o homem recebeu parte da herança da esposa. Em outra lista, a de voluntários no trabalho de reconstrução dos muros de Jerusalém, a Bíblia de Jerusalém diz que Selum participou dos trabalhos do muro junto com os "filhos dele" e não com as "filhas dele" (וּבְנוֹתָיו), conforme o texto hebraico (cf. Ne 3,12). A troca de gêneros não encontra justificativa, pois se Selum não tivesse filhos seria perfeitamente natural que as filhas o ajudassem na obra, uma vez que seriam herdeiras do nome e da propriedade do pai, no entanto, optou-se por supor que mulheres não fariam esse trabalho. ${ }^{499}$

\footnotetext{
497 Cf. B. JANOWSKI, "Der Mensch im alten Israel - Grundfragen alttestamenthcher Anthropologie", p. 167.

${ }^{498}$ Cf. E. S. GERSTENBERHER, Israel no tempo dos persas, p. 126-128.

${ }^{499}$ Cf. T. C. ESKENAZI, "Out From the Shadows Biblical Women in the Postexilic Era", p. 2343.
} 
Provavelmente, havia uma grande reação ao empoderamento feminino da época, o que levou a proposição que judeus despedissem suas mulheres estrangeiras com os filhos (cf. Esd 10,3.11; Ne 9,2), e Zacarias a submeter uma mulher e aprisioná-la no interior de um efá (v.7a). De fato, as preocupações com a tradição religiosa tinham precedência sobre o respeito pela santidade dos laços familiares, mas, primeiro, a desculpa da chuva para adiar a decisão chega a parecer cômica (cf. Esd 10,12-14); segundo, há registro de vozes que discordam da decisão (cf. Esd 10.15); terceiro, havia sacerdotes entre os que realizaram casamentos mistos (cf. Esd 10,18), o que provavelmente influiria em decisão contrária ao desejo de Sequenias; finalmente, a pequena lista dos "culpados", com apenas cento e onze nomes (cf. Esd 10, 18-44), em relação ao número de membros da comunidade, leva a pensar que poucas pessoas atenderam ao pedido de Esdras para afastar esposas e filhos do lar. ${ }^{500}$

Ignora-se "Soferet" (ספְְרת), que significa "a fêmea escriba", indicando a profissão, como chefe de família nas listas de recenseamento dos cronistas (cf. Esd 2,55; Ne 7,57). Em Esd 2,55, Soferet aparece sem artigo, o que poderia indicar um nome ou título, mas, em Ne 7,57, Soferet aparece com artigo definido, o que elimina a hipótese de se ler a palavra como um nome. Provavelmente, se supõe que o texto não poderia fazer referência a um escriba feminino porque a profissão não seria suscetível de existir para uma mulher. Se "Soferet" aparece duas vezes em listas pós-exílicas (cf. Esd 2,55; Ne 7,57), indicando que um clã pode tomar o nome da matriarca que o encabeça, e se a presença de escribas no AOP foi documentada, por que os estudiosos ignoram o aspecto feminino do termo? O descarte é baseado não em aspectos linguísticos, mas em pressupostos que exigem a exclusão de mulheres. Não é o texto bíblico que afasta a presença da mulher, são os intérpretes. ${ }^{501}$

Enfim, Zc 5,5-11 não é um texto misógino, sua mensagem, através do simbolismo de uma mulher sentada no meio do efá, quer apenas mostrar que uma renovação espiritual seria possível. E, ao remover "algumas mulheres", outras, provavelmente, seriam favorecidas. O tamanho da mulher, comparável com o

\footnotetext{
${ }^{500}$ Cf. R. J. BURNS, “Esdras e Neemias”, p. 303-332.

${ }^{501}$ Cf. T. C. ESKENAZI, "Out From the Shadows Biblical Women in the Postexilic Era", p. $23-$ 43.
} 
minúsculo espaço do efá, dá a dimensão simbólica do problema, o mal da comunidade era muito maior do que o desvio que se precisa conter. ${ }^{502}$

"E disse: Esta é a iniquidade. (v.8b)

O quiasmo introduz os elementos, que se contrapõem paralelamente: "um disco de chumbo foi levantado" (v.7a) com "e lançou uma pedra de chumbo para sua abertura" (v.8d); "e esta é uma mulher sentada no meio do efá (v.7b) com "então, lançou-a para o meio do efá" (v.8c). As ações são vigorosas. O centro foi deixado para o que se quer enfatizar, ironicamente, "a iniquidade" (הָרְשָׁׁעָה), no v.8b, no centro, no meio da comunidade. ${ }^{503}$

A imagem no quiasmo (vv.7-8) lembra uma teofania às avessas: YHWH é entronizado (cf. Sl 99,1) no meio dos filhos de Israel (cf. Ez 47,3), exaltado como forte, justo e misericordioso (cf. Sl 93; 97; 99), provocando deslocamento cósmico (cf. Sl 18,8-16) manifestando sua presença, enquanto na visão, ironicamente a mulher está sentada, “entronizada" (v.8c), seu único atributo é a "iniquidade" (v.8b), ela é lançada (v.8c) e enviada ao submundo, num paralelo com os relatos míticos hititas. ${ }^{504}$

O artigo que precede a palavra "iniquidade" (רְשְָׁׁ) a individualiza e mostra objetivamente que se trata de algo de uma categoria específica, já conhecida do leitor. Este artigo personifica a iniquidade. ${ }^{505}$ Como parte da vida da comunidade judaica, a iniquidade é a transgressão no seu sentido mais genérico de infidelidade, reunindo em si todas as formas de ruptura do relacionamento do homem com YHWH, representadas pelo "efá", o "olho deles" e "uma mulher".

A tentativa de estabelecer relação entre a "mulher" (רִ̣) (v.7b) e a

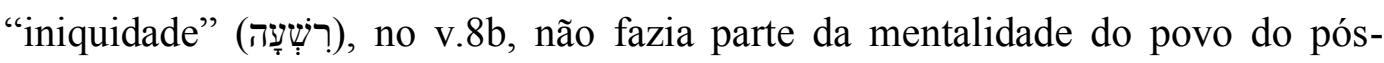
exílio, mas isto é, muitas vezes, forçado por associações etimológicas, como a que

\footnotetext{
502 Cf. M. E. MILLS, Urban Imagination in Biblical Prophecy. New York/London/New Delhi/Sydney: Bloomsbury, 2012, p. 156.

${ }^{503}$ Faz sentido a tradução de C. KÖRTING ("Sach 5,5-11 - Die Unrechtmäßigkeit wird an ihren

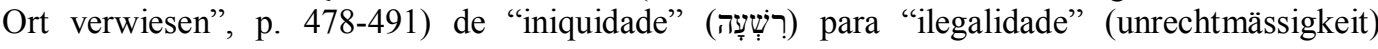
colocada no lugar certo.

${ }^{504}$ Cf. FLOYD, "The Evil in the Ephah", p. 61-62.

${ }^{505}$ Em seu comentário sobre Zc 5,5-11, C. L. MEYERS e E. M. MEYERS (Haggai, Zechariah 18, p. 302) escrevem "Iniquidade" com inicial maiúscula para mostrar o sentido do artigo no tratamento dado à palavra.
} 
identifica nas palavras מִרְשׁעַת , palavras do universo cultual idolátrico que teriam relação com a idolatria praticada no pós-exílio (cf. Is 57,$5 ; 65,1 ; 66,17$; Ml, 2,11), e em conexão também com a prostituição religiosa. ${ }^{508}$

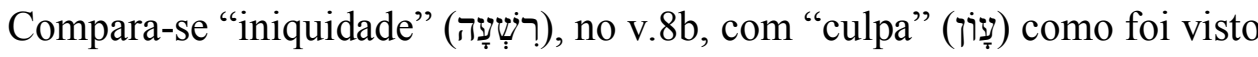
acima. A iniquidade exigiria uma conversão que poderia ser superada pelo culto, enquanto a culpa, estando diretamente relacionada com YHWH, exigiria libertação e purificação. ${ }^{509}$

“Então, lançou-a para o meio do efá.

E lançou uma pedra de chumbo para sua abertura”. (vv.8cd)

O lançamento no meio do efá e a tampa em sua abertura apontam para a tentativa de enfatizar a submissão. O mensageiro é, provavelmente, o sujeito do

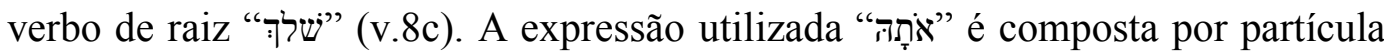
de objeto direto com sufixo de terceira pessoa feminino singular, ou seja, "ela" (v.8c).

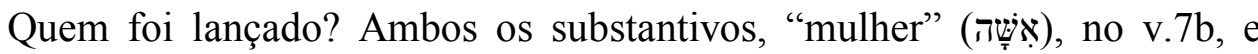

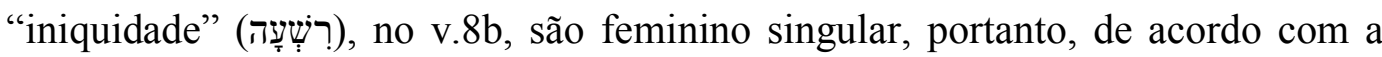
regra da gramática hebraica, a iniquidade foi lançada, pois é ela o substantivo feminino singular mais próximo, anterior ao verbo "lançar", 510

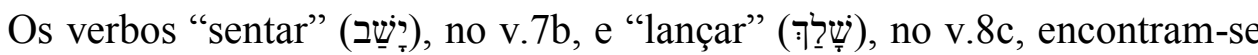
em paralelo no quiasmo, apontando para o contraste entre as ações, submissão e imposição. O verbo lançar está no hifil, indicando uma ação ativa e vigorosa. É possível que a iniquidade tencionasse sair de seu lugar, precisando, portanto, da ação enérgica para ser mantida no meio do efá (v.8c).

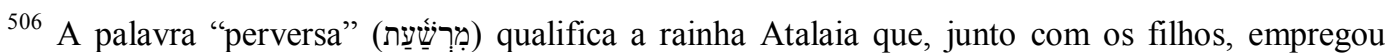
objetos sagrados do Templo no culto aos baais (cf. 2Cr 24,7).

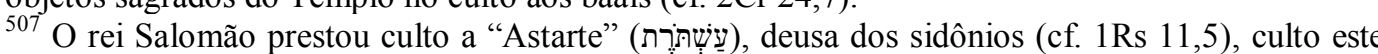
que se espalhou em Israel e terras vizinhas. Para M. DELCOR ("La vision de la femme dans l'épha de Zach.”, p. 143-144), é possível que o profeta Zacarias tenha querido ridicularizar a mulher, como costume de escritores antigos; Baal foi chamado de Boshet, "vergonha" (בָּ), de acordo

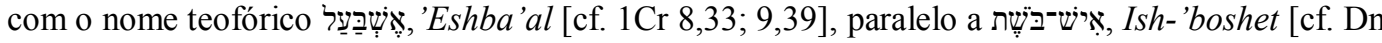
9,8; Mq 1,11].

${ }^{508}$ Cf. M. DELCOR, “La vision de la femme dans l'épha de Zach.”, p. 144.

${ }^{509}$ Cf. C. KÖRTING, "Sach 5,5-11 - Die Unrechtmäßigkeit wird an ihren Ort verwiesen”, p. 480481.

${ }^{510}$ Cf. GHG $\S 146 f(b)$.
} 


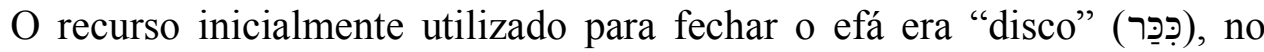
v.7a, se tornou "pedra" (אֶ), no v.8d. O termo "pedra" ou "rocha" (אֶֶן), mais comumente utilizado na BH, ao contrário de "disco" (רכְּ), aponta para a importância do material em Israel. Com múltiplas utilidades a pedra era usada na construção de casas (cf. Am 5,11); nos muros da cidade (cf. Ne 3,55); em cercas (cf. Sl 62,4); para fazer vasos (cf. Ex 7,19); para selar poços (cf. Gn 29,8) e até mesmo como travesseiros (cf. Gn 28,11).

No âmbito religioso usava-se na construção de templos (cf. 1Rs 5,17-18), altares (cf. Ex 20,25) e para fazer ídolos pagãos (cf. Dt 4,28). Constata-se também seu uso em armas (cf. Jz 20,16), pesos comerciais (cf. Dt 25,15) e em escritas (cf. Ex 34,1). ${ }^{511}$ Simbolicamente, as palavras "pedra" e "rocha" servem de título a YHWH (cf. Gn 49,24) e ao Messias (cf. Is 28,16). O termo está relacionado a rochas de diferentes tipos de minerais como ferro e cobre (cf. Dt 8,9), prata, ouro, bronze e safiras (cf. Jó 28,2-10) e pedras preciosas (cf. Ex 25,7; 31,5; Ez 1,26).

Eventualmente, alguma pedra podia receber o nome de um evento local como a "pedra de ajuda" de Samuel (cf. $1 \mathrm{Sm}$ 7,12), podia ter uma função pedagógica em memoriais erigidos para comemorar eventos importantes na história, para ensinar lições teológicas e de fé pactual (cf. Js 4,1-7.19-24).

Enquanto os víveres eram medidos pelo volume, os materiais preciosos e metais eram pesados. As pesagens pequenas eram feitas em balanças de dois braços e os pesos eram, geralmente, de pedras duras chamadas ao mesmo tempo "pedra" e "peso".

O verbo "pesar" (שַָׁ) é usado com maior frequência para o ato de pesar ouro e prata, para realizar um pagamento (cf. Esd 8,24-34). Estes pesos se tornaram moeda do AOM e do período posterior ao exílio. Do ato de "pesar"

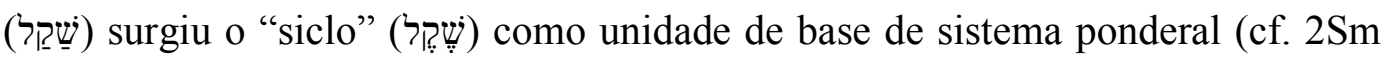
14,26; Gn 23,16).

$\mathrm{O}$ estudo dos pesos leva ao de moedas, para troca de mercadorias (cf. 2Rs $3,4)$, que passou a ser feita com o metal trabalhado ou em lingotes, cuja qualidade e peso determinam o valor de troca (cf. 2 Rs 15,19 ). O metal podia ser fundido em

\footnotetext{
${ }^{511}$ Cf. A. HILL, "אֶֶָּ". In: NDITEAT, v. 1, p. 242-243.
} 
diferentes formas: discos, barras, broches e anéis, às vezes com sinal que certificava o peso e o quilate. ${ }^{512}$

Com isso, pode-se entender o uso do termo "pedra" (אֶ) de chumbo, no v. $8 \mathrm{~d}$, como uma referência a transações comerciais. A menção destes dois elementos com "disco" remete ao pós-exílio, quando foi cunhada a própria moeda do Império Persa. ${ }^{513}$ Sob Dario, entrou em circulação o darico, uma moeda cunhada com selo que autenticava seu nome e peso (cf. Esd 8,27). Contudo, o "talento" (כִּכַ), no v.7a, uma peça de metal redonda, de peso fixo, permaneceu usado no comércio para pagamentos diversos. ${ }^{514}$

A moeda serviu também para a necessidade de trocar o que cada um produzia por outros bens. Quando havia excedentes, a moeda passava a funcionar como reserva de valor, ou seja, um acumulador de riqueza. Desta forma, o acúmulo sem limites, que antes não fazia sentido com a simples troca de mercadorias, agora podia expressar a riqueza do indivíduo. A transformação qualitativa da ordem econômica que isso ocasionou foi expressa por Coélet em sua crítica ao acúmulo do dinheiro (cf. Ecl 5,7-10). ${ }^{515}$

É difícil determinar o peso exato da moeda utilizada em transações comerciais em Judá porque havia diversos sistemas metrológicos no AOM. Na Mesopotâmia, havia moedas "pesadas" e "leves", uma equivalendo ao dobro da outra aproximadamente. Além disso, com medidas determinadas pelo rei, havia ainda a moeda "real" e a "comum". Havia também sistemas de contagem diferentes: os assírios, sumérios e babilônios utilizavam o sistema sexagesimal, os israelitas utilizavam o decimal. ${ }^{516}$

Os textos bíblicos permitem que se verifique a proporção entre os diversos pesos (cf. Ex 38,25-27), conforme visto acima, e todos eles citados em textos bíblicos do pós-exílio, e com importância teológica (cf. Gn 24,22; Ex 37,24; $1 \mathrm{Cr}$ 29,7). ${ }^{517}$ Independentemente destas variações e das imprecisões na confecção do peso, YHWH ordena que os israelitas utilizem pesos honestos, sem aumentar o

\footnotetext{
${ }^{512}$ Cf. L. WALKER “"שֶׁ". In: NDITEAT, v. 4, p. 234-239; R. De VAUX, Instituições de Israel, p. $242-248$.

${ }^{513}$ Segundo R. De VAUX (Instituições de Israel, p. 242-248), Heródoto menciona que Dario, o rei persa, fundia ouro e prata em jarros de terracota e, quando a vasilha estava cheia, era rompida e, depois, cunhada de acordo com a necessidade do momento

${ }_{514}$ Cf. R. De VAUX, Instituições de Israel, p. 242-248.

${ }^{515} \mathrm{Cf}$. R. KESSLER, História social do antigo Israel, p. 220-221.

${ }^{516}$ Cf. J. E. SHEPHERD, "שֶק?". In: NDITEAT, v. 4, p. 234-238.

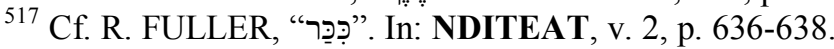


siclo para enganar o cliente, vendendo quantidade menor pelo mesmo valor (cf. Am 8,5). ${ }^{518}$

A mudança do sistema de troca de bens, com diferentes padrões de peso e qualidade, a existência de frações desta moeda (גָרָרה $)^{522}$ e o duplo sistema de numeração podem ter contribuído para aumentar a situação de miséria das famílias pobres de Judá no pós-exílio, exploradas pela classe rica que dominava o comércio de trocas. ${ }^{523}$

Esta classe rica era composta pelos que retornavam do exílio e compunham uma elite convicta de que era herdeira legítima do Israel monárquico. Foram grandes os conflitos quando, após duas ou três gerações, esta classe de retornados reivindicava o direito às propriedades deixadas para trás e impunha crescente situação de pobreza com a reconstrução do Templo e o poder financeiero e intelectual que detinham (cf. Is 56,3-7). ${ }^{524}$

Uma classe privilegiada, esquecida da antiga solidariedade entre os irmãos, lucrava emprestando aos que não tinham como pagar o imposto cobrado pelo Império Persa, aumentando o empobrecimento da população menos favorecida: assalariados, órfãos, viúvas e migrantes. (cf. Ag 1,6; Is 61,1ss). Os que praticavam os males sociais eram os que não temiam a YHWH (cf. Ml 3,5). ${ }^{525}$

Assim, os "adornos" da visão tornam-se também mensagens divinas: o

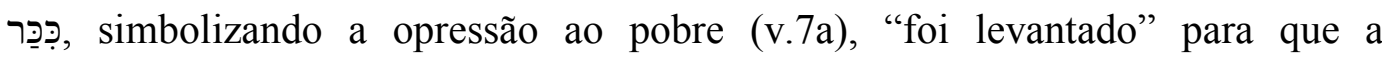
transgressão da comunidade possa ser vista e refletida; e o misericórdia divina, presente na natureza e "lançada" na abertura do efá (v.8d) para aprisionar e remover o mal.

O confinamento do mal no efá com auxílio de uma tampa de "chumbo" (עְִֶרת) encontra paralelo em relatos do mundo antigo, alguns dos quais citam vasilhames tão pequenos que são considerados de "natureza mágica", remetendo às lendas de garrafas que contêm demônios. ${ }^{526} \mathrm{O}$ mundo hitita oferece relatos que

\footnotetext{
${ }^{518}$ Cf. J. E. SHEPHERD, “שֶׁקֶֶ?". In: NDITEAT, V. 4, p. 237.

${ }^{519}$ Cf. 1Rs 10,17; Ez 45,12; Esd 2,67; Ne 7,70s.

${ }^{520} \mathrm{Cf}$. Ex 38,24; Ez 4, 10; Am 8,5.

${ }^{521}$ Cf. Ex 38,26; Jo 28,10; S1 78,13.

${ }^{522}$ Cf. Lv 11,1; Dt 14,6.7.8; Ez 45,12.

${ }^{523}$ Cf. J. BRIGHT, História de Israel, p. 493-505.

${ }^{524}$ Cf. J. L. SICRE, Com os pobres da terra, a justiça social nos profetas de Israel. São Paulo: Paulus; Santo André: Academia Cristã, 2015, p. 526-545.

${ }^{525} \mathrm{Cf}$. R. ALBERTZ, Historia de la religión de Israel em tiempos del Antiguo Testamento, p. 590-591; R. KESSLER, História social do antigo Israel, p. 176-184.

${ }^{526}$ Cf. M. DELCOR, “La vision de la femme dans l'épha de Zach.”, p. 138.
} 
mostram soluções legais para rebeliões, alguns dos quais se assemelham ao aprisionamento no efá. Neles, a punição não é proporcional à transgressão: aquele que se opuser ao julgamento do rei terá a casa saqueada; aquele que se opuser ao julgamento de um dignitário será decapitado; um escravo que se rebelar contra seu mestre será colocado dentro de um recipiente. ${ }^{527}$

Em outro relato hitita, o confinamento é feito em uma jarra utilizada para o armazenamento do trigo, fechada com uma tampa de chumbo. ${ }^{528}$ Para este povo, o chumbo possuía a propriedade mágica de ser impenetrável pelos espíritos e, por isso, era também utilizado para o confinamento do demônio. ${ }^{529}$

No entanto, de acordo com uma inscrição púnica em que aparece o termo עִפְּר mágica ao chumbo, como ocorre com uma inscrição para que os deuses aprovassem o dinheiro (prata) derramado como chumbo, o que leva a pensar numa questão ético-religiosa. ${ }^{530}$

Estes relatos mostram algumas semelhanças com Zc 5,5-11 quanto ao confinamento, ao material utilizado para fechar o efá e à punição extraordinária. Em relação aos significados simbólicos dos objetos utilizados, "disco" (v.7a) e "pedra" (v.8d), e o material destes objetos, o "chumbo", observa-se que formam um tipo especial de quiasmo com os "adornos" da cena, representados pelo objeto que fecha o efá, convergindo para o chumbo no centro, como a enfatizar o tema central da visão, a ética nas relações comerciais.

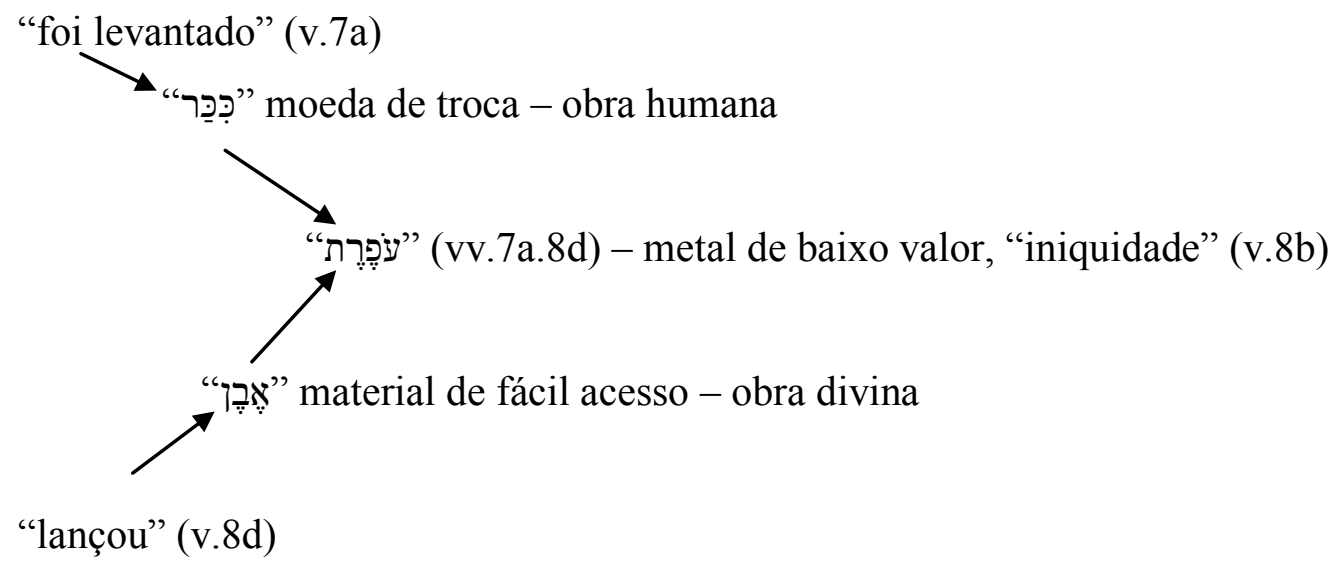

\footnotetext{
${ }^{527}$ Cf. M. DELCOR, “La vision de la femme dans l'épha de Zach.”, p. 140.

${ }^{528}$ Segundo M. DELCOR (“La vision de la femme dans l'épha de Zach.”, p. 139), sabe-se que o rei indiano Payasi encerrou um ladrão em uma grande jarra de barro e depois a fechou hermeticamente com argila.

${ }_{529}$ Cf. M. DELCOR, “La vision de la femme dans l'épha de Zach.”, p. 141.

${ }^{530}$ Cf. A. H. KONKEL, "עפכָּרֶת". In: NDITEAT, v. 3, p. 473.
} 
Portanto, também o "chumbo" faz parte da denúncia central do profeta, contrapondo-se, de um lado, a fragilidade humana, e de outro, a misericórdia divina, fazendo refletir sobre o caminho para uma nova era.

\section{2 .2$.}

\section{Cena II: (Zc 5,9)}

Levantei meus olhos $9 \mathrm{a}$ e vi.

E eis que duas mulheres saíram $\quad 9 \mathrm{c}$ e havia vento nas asas delas; $9 \mathrm{~d}$ e elas tinham asas, como asas de 9e cegonha,

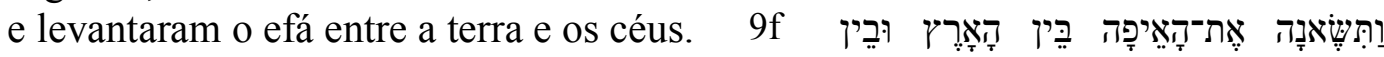

\section{"Levantei meus olhos e vi.}

E eis que duas mulheres saíram e havia vento nas asas delas;

e elas tinham asas, como asas de cegonha," (vv.9a-e)

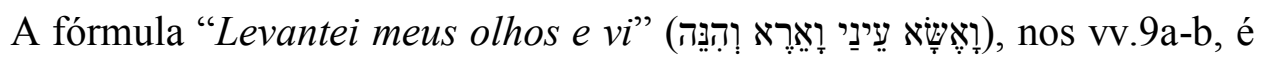
semelhante às que iniciam outras visões (cf. Zc 2,1; 2,5; 5,1) e esta visão (v.5c), separando uma visão da anterior, funcionando nesta cena como uma fórmula de transição. Provavelmente, o uso da fórmula abrindo o desfecho da visão tenha por objetivo estabelecer o clímax, que é o foco da visão. Para enfatizar esse uso, a

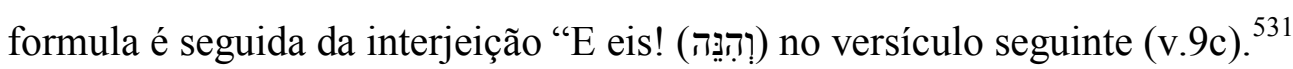

A imagem retrata o profeta olhando para o objeto da visão. Para a descrição do olhar do profeta são utilizados os verbos "levantar" (נְָָשָאָ) e "ver" (רָָָ): "levantei meus olhos e vi" (vv.9ab), que dão continuidade à segunda parte da narrativa, diferentemente da fórmula de introdução, no imperfeito, e não no imperativo. Nesta transição, em vez de o mensageiro participar explicando a visão, o próprio profeta levanta, vê e descreve a cena revelada (vv.9cf). Esta fórmula parece cumprir a função de inserir as informações que darão sentido à visão, permitindo seu entendimento. É possível que a sequência apresentada nesta

\footnotetext{
${ }^{531}$ Cf. M. J. BODA, The Book of Zechariah, p. 340-355.
} 
fórmula, com comando e realização do comando, pudesse ter sido norma, tendo sido preservada em Zc 5,5-11 e omitida nas outras visões, onde há sequência de tempo. ${ }^{532}$

A fórmula introdutória é imediatamente seguida da segunda cena: “ $E$ eis

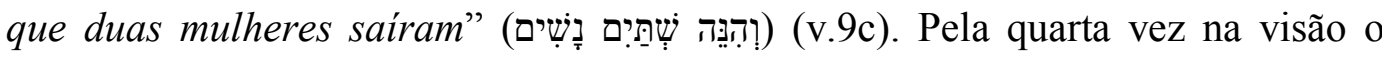
verbo "sair" (יָָָא) está sendo usado para revelar algo ao profeta: o profeta sai (v.5a); o mensageiro identifica algo saindo (v.5e) e depois o efá (v.6d), e, finalmente, duas mulheres com asas como de cegonha (v.9c).

O numeral "duas" (שَשְת), no feminino dual, concorda em gênero e número com "mulheres" (ְְְִָׁים), no feminino plural (v.9c). A discrepância de gênero

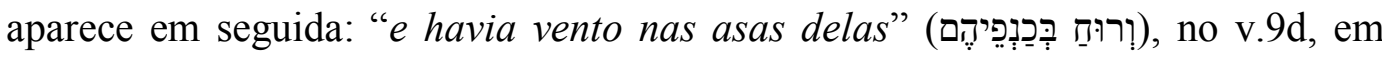
relação ao sufixo pronominal masculino plural de "asas" (כฺָָָ), em referência às mulheres (v.9d).

As asas das mulheres rufam com o "vento" (רֵּח), ${ }^{533}$ em movimentos que se repetem em conformidade com o sentido onomatopeico do termo (vv.9d.e). ${ }^{534} \mathrm{O}$ ar e as asas se confundem no movimento que fazem, e uma energia se desprende

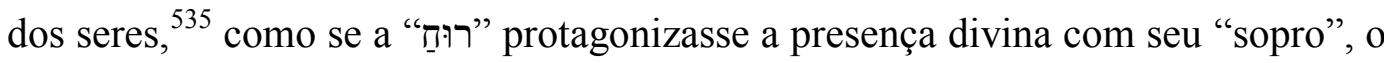
mesmo encontrado no dilúvio quando YHWH lembrou-se de Noé e baixou as águas (cf. Gn 8,1), ou quando o "vento de YHWH" fez o mar recobrir os carros e as tropas do faraó, na fuga do Egito (cf. Ex 15,10). ${ }^{536}$

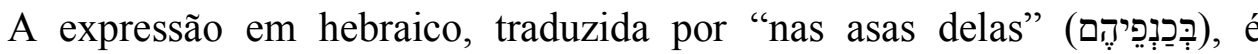
constituída do substantivo construto "asas" (כฺָָָָָ), no v.9d, com sufixo masculino plural. Há, portanto, uma discrepância, pois as asas estão em referência ao

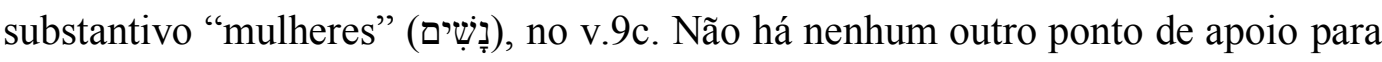

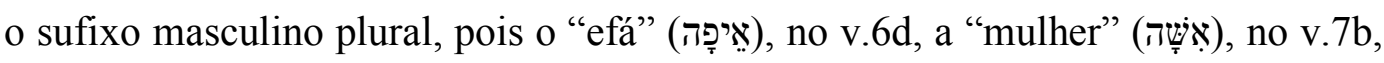

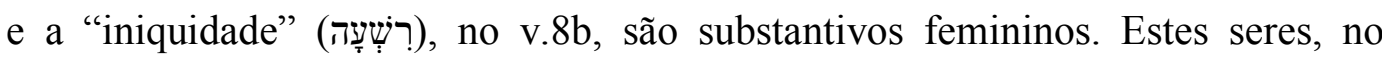
entanto, lembram os querubins, considerados assistentes de YHWH, seres masculinos, muito presentes na literatura bíblica (cf. Gn 3,24; Ez 1,4-11), ${ }^{537}$ que não transportariam a iniquidade num culto javista. É possível, portanto, que se

\footnotetext{
${ }^{532}$ Cf. C. L. MEYERS; E. M. MEYERS, Haggai, Zechariah 1-8, p. 293-309.

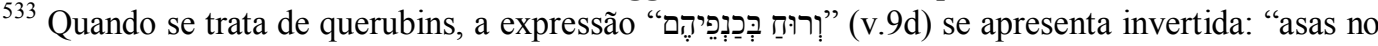
vento" (cf. S1 18,11; 2Sm 22,11).

${ }^{534} \mathrm{Cf}$. GHB $\S 30$ h-k. p. 101-102.

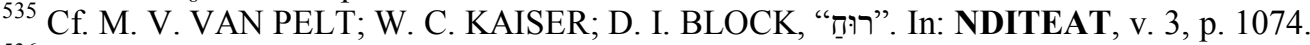

${ }^{536}$ Cf. M. J. BODA, The Book of Zechariah, p. 351-352.

${ }^{537}$ Cf. C. KÖRTING, "Sach 5,5-11 - Die Unrechtmäßigkeit wird an ihren Ort verwiesen", p. 481; cf. também Ex 25,10-22; 37,7-9; 1Rs 6,29.32.35; 1Sm 4,4; 2Sm 6,2; 2Rs 19,15; 1Cr13,6.
} 
tenha optado por usar o sufixo no masculino para separar as mulheres com asas de cegonha dos querubins. O pensamento javista resolveu um problema, mas manteve outro, pois seres femininos seriam impotentes para carregar o fardo a elas atribuído. $^{538}$

Outra explicação seria um enfraquecimento havido na distinção do gênero, na passagem da linguagem coloquial para a literária, que provocaria não raras ocorrências dos sufixos masculinos, especialmente no plural, em referência a substantivos femininos (cf. Ct 6,8; Rt 1,22). ${ }^{539}$

Ou, simplesmente, a discrepância faz parte do caráter simbólico sobrenatural da visão. A imagem de seres com asas remete às representações iconográficas em que os seres "estão no ar" e apenas precisam de suas asas para cumprir a tarefa divina. ${ }^{540}$

Chama a atenção, contudo, o fato de as mulheres terem asas assemelhadas às de cegonha. Os querubins nunca são descritos com asas que se assemelham às de alguma ave. No entanto, a comparação das asas com as da cegonha tem aspecto negativo e positivo. Negativo porque as cegonhas são consideradas animais que

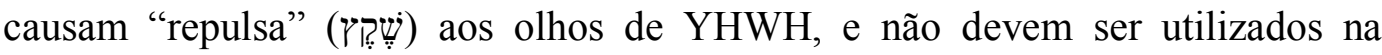
alimentação (cf. Lv 11,19). Positivo porque cegonhas, com sabedoria, migram no tempo certo (cf. Jr 8,7), utilizando a rota certa (da Palestina para o norte, em direção à Babilônia) e em busca do lugar certo, onde constroem seus ninhos em árvores (cf. Sl 104,17). ${ }^{541}$

Além disso, a raiz da palavra "cegonha" (חִִִָידָה; cf. Lv. 11,19; Dt 14,18) é comum às palavras "bondade" (דָסְד), em Gn 21,23; S1 33,5, e "piedoso" (דָסִיד), em $1 \mathrm{Sm} 2,9 ; \operatorname{Jr} 3,12$, cujo fundamento é a lealdade e o amor nas alianças estabelecidas por laços de parentesco ou de fidelidade. ${ }^{542}$

Assim, em relação à sabedoria da cegonha, na busca do tempo e da rota para voar em direção ao norte (Senaar), evidenciam-se lealdade e amor intrínsecos

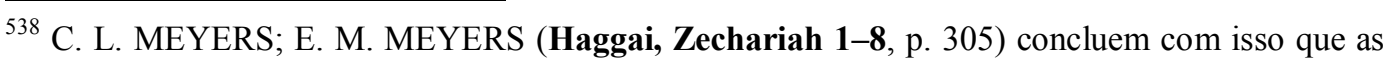
mulheres com asas de cegonha talvez sejam de fato figuras javistas.

${ }^{539}$ Cf. GHG, § 135 o.

${ }^{540}$ Cf. C. KÖRTING, "Sach 5,5-11 - Die Unrechtmäßigkeit wird an ihren Ort verwiesen”, p. 482.

${ }^{541}$ Ainda hoje, cerca de quinhentas mil cegonhas brancas migram por Israel duas vezes por ano. Entre os diferentes padrões de migração natural, entre Judá e Mesopotâmia, na rota da primavera, um dos deslocamentos é para o leste de Israel, através do deserto, em direção à região do Mar Cáspio, passando perto da antiga Babilônia (cf. C. L. MEYERS; E. M. MEYERS, Haggai, Zechariah 1-8, p. 306-307; M. J. BODA, The Book of Zechariah, p. 351-352).

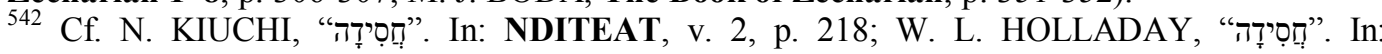
LHAAT, p. 157-158.
} 
à raiz da palavra, e a semelhança das asas com as de uma cegonha faz todo o sentido na tarefa divina do transporte do efá. ${ }^{543}$

A ideia de que seriam necessárias duas mulheres por causa da carga (uma mulher $)^{544}$ não tem sentido, pois a visão é feita de imagens extraordinárias como a de uma mulher caber sentada dentro de uma vasilha de medição, pequena para o feito. "Duas mulheres" executando tarefa divina e com asas como asas de "cegonha" e gênero masculino para o sufixo "delas" pode significar uma revisão ao pensamento da corrente dominante da comunidade em crise. ${ }^{545}$

A presença de "mulheres" desempenhando uma tarefa divina torna-se pertinente com a ideia de eliminação de atitudes de exclusão e pertença da corrente de retornados da Babilônia. A impureza contamina e deve ser removida através de um rito de purificação para que as relações com YHWH e com o outro voltem a ser estabelecidas. A imagem de "duas" e não uma mulher pode estar mostrando a cooperação que há entre as mulheres, somente isso.

"e levantaram o efá entre a terra e os céus." (v.9f)

O verbo "levantar" (נְָָָׁא), no v.9f, possui núcleo semântico que inclui causas e efeitos, projeto e execução, podendo assumir o significado mais amplo de transportar planejadamente. ${ }^{546}$ Estes aspectos parecem fazer parte da tarefa de transportar que inclui construir uma casa, prepará-la, e assentar o efá sobre a base

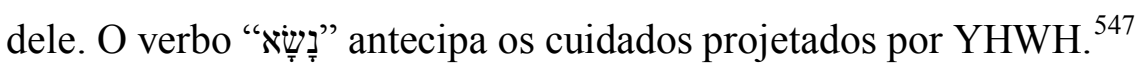

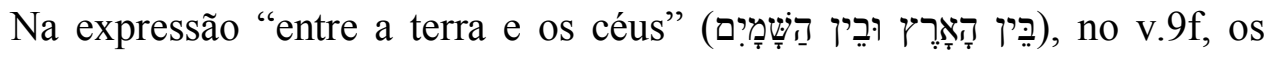
substantivos "terra" (אֶרץ) e "céus" (שֵָׁמיִם) estão precedidos de artigo, dando notoriedade e têm conotação de movimento (cf. 2Sm 18,9). ${ }^{548} \mathrm{O}$ substantivo terra tanto pode ser usado no sentido cosmológico (cf. Gn 1,9-13; Sl 24,1), como pode

\footnotetext{
${ }^{543}$ M. H. FLOYD ("The evil in the ephah", p. 51-68) discorda, pois para ele estas mulheres estão indo instalar um culto idólatra em Senaar, tarefa incompatível com um agente de YHWH.

${ }^{544}$ Pensa desta forma W. RUDOLPH (Haggai - Sacharja 1-8 - Sacharja 9-14 - Maleachi, Mit p. 118-121).

${ }_{545}$ Cf. R. GIRARD, O bode expiatório. São Paulo: Paulus, 2004, p. 133-147.

${ }^{546}$ Cf. L. ALONSO SCHÖKEL. "“שָָׁ". In: DBHP, p. 450-453.

${ }^{547}$ Para M. H. FLOYD ("The evil in the ephah", p. 51-68), a ação do verbo "אָָֻׁ" é o "efeito ou resultado da violação de uma norma ética ou cúltica".

${ }^{548}$ Cf. D. T. TSUMURA, "אֶָ?". In: NDITEAT, v. 4, p. 164.
} 
representar uma determinada designação territorial, principalmente em referência a Israel (cf. Gn 15,18). ${ }^{549}$

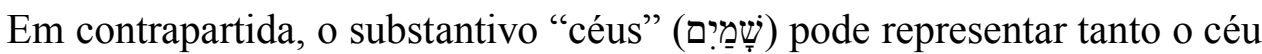
físico como a morada de YHWH. Como céu físico, abrange tudo que está acima da terra. Em outra visão, Zacarias fala em "quatro ventos do céu" saindo dos domínios divinos (cf. Zc 2,10). A imagem tem grande força de comunicação em hebraico por ser a morada de YHWH (cf. Dt 26,15; 1Rs 8,30), lugar de onde Ele determina sua vontade na terra. ${ }^{550}$

Não é o profeta que é levantado "entre a terra e os céus" (cf. Ez 8,3), mas o efá com toda sua carga do mal, devido às injustiças que representa (cf. Ez 8,3; $1 \mathrm{Cr}$ 21,16). ${ }^{551}$ As duas mulheres agem sob comando divino e executam a ação com vento em suas asas, o "vento" (רָּר), no v.9d, representando o Espírito de YHWH "entre a terra e os céus", espaço da atividade cósmica e soberania divinas.

Realidade e sonho se contrapõem nas imagens, o efá representando o pecado em toda a terra (v.9f), mostrando a preocupação do profeta com uma restauração entre o puramente mundano e uma utopia. ${ }^{552}$ Diante da situação histórica, social e política do retorno no pós-exílio, em que o povo quer saber o que esperar das ações divinas, os profetas contemporâneos respondem às perguntas: YHWH estará presente em Jerusalém? Como a questão da transgressão humana será abordada? Como as transgressões serão expurgadas, e a contaminação da comunidade evitada? ${ }^{553}$

Ageu responde com a unção de Zorobabel como rei (cf. Ag 2,20-23) e a reconstrução dos muros de Jerusalém (cf. Ag 1,1-11), destruídos há mais de um século. Zacarias prevê uma restauração alternativa na sua resposta: YHWH não ficará restrito ao Templo, haverá um muro de fogo ao redor de Jerusalém (cf. Zc 2,5-9). Inicia-se uma nova ordem social e religiosa com Zorobabel e Josué (cf. Zc $3,1-10){ }^{554}$

\footnotetext{
${ }^{549}$ Cf. V. HAMILTON, "אֶּר". In: DITAT, p. 124-125.

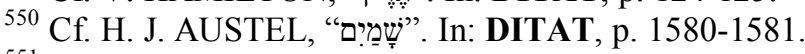

${ }^{551}$ O espírito levantou o profeta Ezequiel entre o céu e a terra "em visões divinas" para que visse a culpa de Jerusalém pelos pecados com o "ídolo do ciúme" (cf. Ez 8,3); Davi vê o mensageiro de YHWH entre a terra e o céu, com a espada desembainhada e voltada contra Jerusalém (Em $1 \mathrm{Cr}$ 21,16).

${ }^{552}$ Segundo D. L. PETERSEN (Haggai and Zechariah 1-8, p. 110-125), Ezequiel detalha a nova ordem como real (cf. Ez 40-48), Ageu como uma ordem palpável (cf. Ag 2,6-7.14-16) e Zacarias entre utopia e realidade.

${ }_{553}$ Cf. D. PETERSEN, Haggai and Zechariah 1-8, p. 114.

${ }^{554}$ Cf. D. PETERSEN, Haggai and Zechariah 1-8, p. 114.
} 
O quadro de respostas se amplia com a restauração das relações sociais e religiosas simbolizadas pelo efá, catalisador de toda a transgressão da comunidade, movendo-se por uma ordem cósmica que afetará o mundo todo e não somente Judá. $^{555}$

\section{3.}

Desfecho (Zc 5,10-11)

Então, eu perguntei ao mensageiro que 10a falava comigo:

Para onde elas estão levando o efá? $\quad 10 \mathrm{~b}$

E ele me respondeu: $11 \mathrm{a}$

Para construir para ele uma casa na terra $11 \mathrm{~b}$

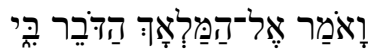
de Senaar, e será preparada, $11 \mathrm{c}$

e lá será assentado sobre a base dele. $\quad 11 \mathrm{~d}$

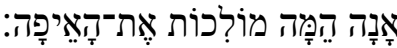

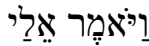

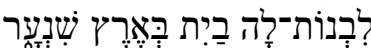

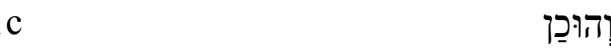

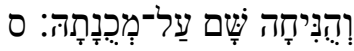

\section{"Então, eu perguntei ao mensageiro que falava comigo:}

Para onde elas estão levando o efá?" (vv.10a-b)

Após descrever a cena revelada (vv.9af), o profeta retoma o diálogo com o mensageiro e pergunta com interesse: "Para onde elas estão levando o efá?" (v.10b). Desta vez, o profeta não parece interessado na explicação do que vê, mas sim, especificamente, no destino do efá. O conjunto utilizado na pergunta: "para onde" (אָנָדה הָָָָה) acentua o movimento das duas mulheres com asas de cegonha para fora de Judá e parece repetir o que o profeta pergunta no início da visão: "Que é aquilo?" (v.6b). ${ }^{556}$

O verbo "levar" (הָָָר), no hifil particípio, remete à conduta do homem em relação à obediência ou não à lei de YHWH (cf. Sl 142,3-4; Jr 18,15). ${ }^{557}$ O verbo possui sentido figurado de processo de retomada de caminho na direção de um comportamento ético: "Por quais caminhos elas estão levando o efá?" (cf. Jr $18,15){ }^{558}$

\footnotetext{
${ }_{555}^{5}$ Cf. D. PETERSEN, Haggai and Zechariah 1-8, p. 114.115.

${ }^{556}$ Cf. C. L. MEYERS; E. M. MEYERS, Haggai, Zechariah 1-8, p. 293-309.

${ }^{557}$ Cf. E. H. MERRIL, "רָדָ". In: NDITEAT, v. 1, p. 1006-1009.

${ }^{558}$ Cf. L.ALONSO SCHÖKEL, “הָדָ". In: DBHP, p. 176-177.
} 
Há uma nova discrepância, mais direta que a ocorrida em "nas asas delas" (v.9d); o pronome no masculino plural "eles" (הָדָּה ) contraria gramaticalmente o substantivo "mulheres" (cf. v.9c) e o verbo "levar" (דָרָ), ambos no feminino plural. Contudo, o profeta está mais preocupado em saber para onde estão levando o efá. 559

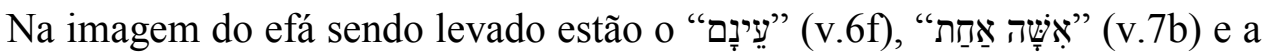

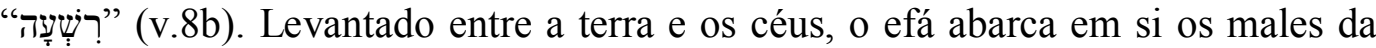
comunidade, a iniquidade (vv.8a-b), o comércio desonesto (cf. Am 8,5); a deslealdade em espionar o irmão (v.6f).

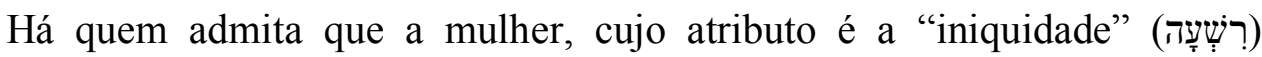
(v.8b), seja o protótipo da "ilegalidade. ${ }^{560}$ "Ela não é uma deusa nem a imagem de uma deusa, ela é literalmente uma mulher", ${ }^{561}$ problemática, no entendimento da comunidade, com certa autonomia, que precisava ser removida da comunidade.

Pode-se pensar que foi intencional a discrepância entre o pronome (masculino) e as duas mulheres (feminino) na expressão "Para onde elas estão

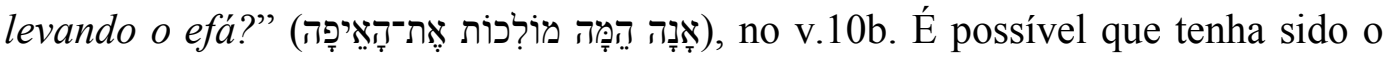
redator consciente de que seres celestiais, que executam tarefas divinas, devem ser do sexo masculino. Assim, ele achou melhor acrescentar o pronome masculino

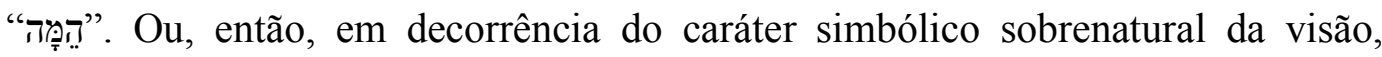
permitiu-se tratar "elas" como "eles".

"E ele me respondeu:

'Para construir para ele uma casa na terra de Senaar," (vv.10a-b)

A resposta detalhada do mensageiro: "Para construir para ele uma casa na terra de Senaar," (vv.11b-d) aponta para a importância da tarefa. O verbo “construir" (פָָָָָָּ), no infinitivo construto, está acompanhado de preposição com sufixo de feminino singular ("לָ"), concordando com o substantivo a que se refere, o "efá" (איפָּה), feminino em hebraico (v.10b). A tradução "para ele" atendeu à concordância do substantivo masculino singular com o pronome também masculino singular, em português.

\footnotetext{
${ }^{559}$ Cf. L.-S. TIEMEYER, "The Vision Report Genre between Form-Criticism and RedactionCriticism: An Investigation of Amos 7-9 and Zechariah 1-6", p. 234.

${ }_{560}$ Cf. C. L. MEYERS; E. M. MEYERS, Haggai, Zechariah 1-8, p. 302-303.

${ }^{561}$ Cf. M. H. FLOYD, "The Evil in the Ephah, p. 62.
} 


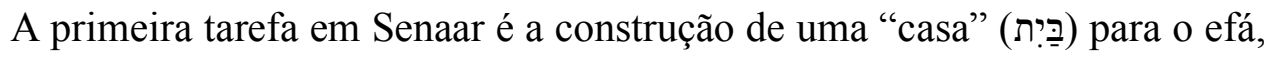
assim como foi a primeira iniciativa humana depois da queda (cf. Gn 4,17). O verbo "construir" (בָָָָָּ) tem o sentido também de assentamento ou constituir família, ${ }^{562}$ como na lei do levirato, em que estava por trás o desejo de manter a riqueza na família, antigo costume que os anciãos tentavam fazer valer com sua autoridade moral (cf. Dt 25,9). Na construção da família, as mulheres têm papel especialmente relevante (cf. Gn 16,2; Rt 4,11), mas sua prosperidade e proteção não dependem do ser humano, pois nada pode ser construído com sucesso sem o envolvimento e a bênção divinos (cf. S1 127,1). ${ }^{563}$

O substantivo "casa" (ת.10b) tem o sentido físico de "casa" ou "habitação" (cf. Ex 12,7; Lv 25,29; Dt 11,20), ou o de "aposentos" de uma casa (cf. Est 2,3; 7,8; Jr 36,22), e também simbólico de: a) "família" ou os que nela vivem, como "casa de Jacó" (cf. Gn 35,2); b) “descendentes” de um grupo, como “casa de Davi" (cf. 2Sm 7,11); c) povo de YHWH, como "casa de Israel” (cf. Ex 16,31 ); d) famílias fiéis à aliança divina, como "casa para servir YHWH" (cf. Js $24,15)$; e) lugar de descanso dos mortos, como "casa eterna" ou "casa destinada a todos os viventes" (cf. Jó 30,23). ${ }^{564}$

A casa era o local onde as famílias comiam, dormiam e se protegiam do calor, do frio e de ladrões (cf. Jó 24,16); a casa recebia também características morais, como "casa rebelde", ou condição de existência, como "casa de escravos" ou "Egito". ${ }^{565}$ Em Zc 5,5-11, o termo " "הe se configura uma "casa rebelde", onde coexistem metaforicamente aqueles que praticam o mal.

Esta "casa rebelde" será construída na "terra de Senaar" (אֶרץ שִשְנָער), no v.11b. Dois relatos ligam "terra de Senaar" a Babel, uma das cidades de Senaar, tida como antigo nome da Babilônia, para justificar a construção de uma casa para o mal em Senaar: os relatos da tábua das nações (Gn 10,1-32) e o da Torre de Babel (cf. Gn 11,1-9).

No primeiro, Senaar está relacionada com dois pecados: o de Cam, filho de Noé, que pecou por ver a nudez do pai e, por isso, foi amaldiçoado; e o do neto de Cam, Nemrod, um tirano fundador de um reino em Senaar, cuja ascendência é

\footnotetext{
${ }^{562}$ Cf. L. J. HOPPE, "Deuteronômio", p. 208.

${ }^{563}$ Cf. D. M. FOUTS, “רָָָּּד". In: NDITEAT, v. 1, p. 655-658; cf. também R. J. CLIFFORD, "Salmos", p. 207.

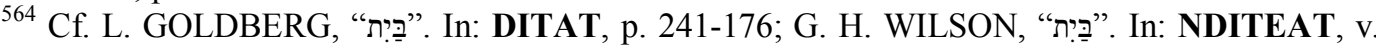
1, p. 633-635.

${ }^{565}$ Cf. J. L. MCKENZIE, “casa”, Dicionário bíblico, p. 139-141.
} 
uma crítica antecipada à Babilônia que levou o povo de Israel ao exílio (cf. Gn 9,18-27). ${ }^{566}$ No segundo, Babel, famosa pelos zigurates, é a cidade da torre que a humanidade, por rebeldia, construiu em desafio a Deus, e por isso foi considerada a terra do pecado. ${ }^{567}$

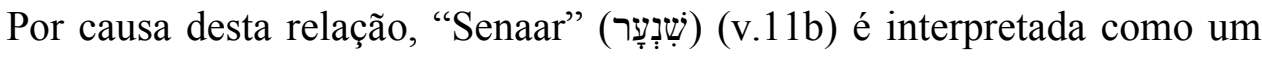
lugar funesto, centro de desenvolvimento de uma civilização e cultura estabelecidas sobre uma religião idolátrica, infiel a YHWH. ${ }^{568}$ Contudo, não se pode identificar exatamente os lugares mencionados nestes relatos. ${ }^{569}$ Além disso, em Gn 10,1-32, a intenção é apenas apresentar um quadro em que as nações conhecidas de Israel no século VI a.C. ${ }^{570}$ não eram separadas por raça e língua, e sim pela geografia e afiliações políticas", e YHWH reinava no meio delas. ${ }^{571} \mathrm{Gn}$ 11,1-9 quer apenas mostrar o juízo divino para Babel, que pecou por desejar viver independente de YHWH. ${ }^{572}$

Por causa desta relação, Senaar é frequentemente considerada lugar de pecado, sinal de orgulho e rebeldia contra YHWH. A "torre cujo ápice penetre os céus" (cf. Gn 11,4) é associada às torres que as cidades antigas construíam como torres de vigia, como estratégia de defesa. Não há fundamento na identificação de tais torres com um templo babilônico (zigurates), pois mesmo que o efá fosse associado aos zigurates, não há um significado religioso para torre. ${ }^{573}$

Em Zc 5,5-11, Senaar é a indicação teológica de uma metáfora para

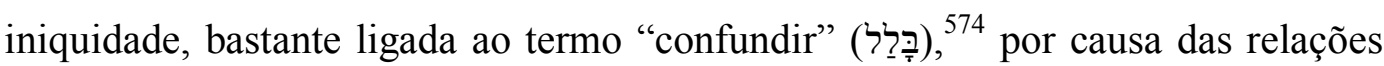
corrompidas com YHWH e com o próximo. No entanto, a determinação divina de

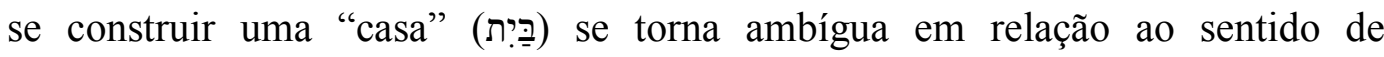
"acolhimento" que é atribuído ao termo, o que pode ser relacionado com a misericórdia divina que não desampara ninguém.

\footnotetext{
${ }^{566}$ Cf. G. J. WENHAM, “Gênesis”, CBVN, p. 113.

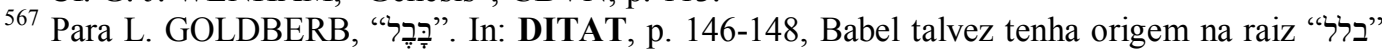
do verbo "confundir".

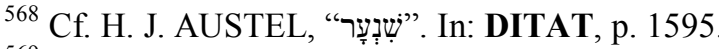

${ }^{569}$ Cf. W. MACDONALD, "Gênesis", CBPAT, p. 23.

${ }^{570}$ Sob o ponto de vista de G. J. WENHAM ("Gênesis", CBVN, p. 113), Gn 10,1-32 mostra: a) a relação entre a linhagem de Sem e as outras não eleitas; b) que as linhagens se formaram segundo as terras, e cada qual segundo sua língua e nação; c) a dispersão não foi castigo, mas plano divino, cujo poder se manifestou na diversidade de povos e unidade do gênero humano acima de etnias, famílias ou nações.

${ }^{571}$ Cf. P. A. VIVIANO, “Gênesis”, Comentário bíblico, p. 67.

${ }^{572}$ Cf. G. J. WENHAM, "Gênesis", CBVN, p. 114.

${ }^{573}$ Cf. G. J. WENHAM, "Gênesis”, CBVN, p. 68.

${ }^{574}$ Cf. L. GOLDBERB, "בלר". In: DITAT, p. 146-148
} 
A Palavra de YHWH já declarara a universalidade de seu domínio: "toda a terra repousa e está tranquila" (cf. Zc 1,11) e "os sete olhos de YHWH percorrem toda a terra" (cf. Zc 4,10b). YHWH, com pedagogia e infinita misericórdia, espera não somente a volta do pecador, também a de todos os povos e habitantes de cidades grandes que convidarão outras dizendo: "Vamos e roguemos a YHWH, busquemos YHWH, eu também irei” (cf. Zc 8,21).

"e será preparada,

e lá será assentado sobre a base dele." (vv.11c-d)

O mensageiro não fornece detalhes da construção da casa, apenas acrescenta sem que seja indagado: "e será preparada" (v.11c). O verbo "preparar" (כּוּ) tem o sentido também de "ficar firme", "resistir", podendo ter também nuanças como de "estabelecer" um reino (cf. 1Rs 2,46), de "ser firme" de coração (cf. Sl 57,7), de "pôr em ordem" materiais de construção (cf. 1Cr 22,3), de acordo com o contexto literário. ${ }^{575} \mathrm{O}$ significado de "pôr em ordem" parece adequado no contexto de novas atitudes no relacionamento com YHWH e com o próximo.

A raiz כון tem também relação com a atividade cósmica divina, que tanto pode ameaçar como sustentar a existência humana. No hofal, parece indicar uma obrigação na execução da ação, ou seja, a construção da casa não foi uma ação livre e espontânea, mas uma ação estabelecida por YHWH, agindo em favor do ser humano (cf. Sl 119,5; Jr 10,23; 1Cr 17,24). ${ }^{576}$

O verbo כּּוּ, no masculino singular, refere-se ao substantivo anterior mais próximo, "casa" (콕), também masculino singular (v.11b). Assim, a preparação da casa ratifica a misericórdia divina, mesmo diante da infidelidade humana, misericórdia que se estende com o uso do verbo "assentar" (ָํ), no v.11d.

O verbo “assentar” (ֵํ), no v.11d, possui vários sentidos, o mais comum é o de "vir descansar em algum lugar" ou de "ser levado a descansar" ou de "ser colocado em certo lugar" (cf. Ex 10,4; Nm 10,36), ou ainda a ideia de “empoleirar-se" ou "pousar sobre" (cf. Gn 8,4.9). ${ }^{577}$ O verbo נַוּ está na terceira

\footnotetext{
${ }^{575}$ Cf. E. A. MARTENS, “פּוּןּר”, In: NDITEAT, v. 2, p. 615.

${ }^{576}$ Cf. E. A. MARTENS, “פּוּן "In: In: NDITEAT, v. 2, p. 615-616.

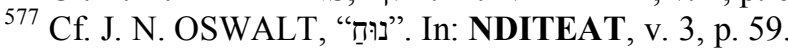


pessoa do masculino singular, em concordância com o substantivo antecedente “casa" (פבּית), masculino singular.

O verbo "assentar" (נוּח) faz lembrar que há um momento para descansar e um momento para parar (cf. Ex 23,12; Dt 5,14), sabedoria própria de Israel justificada e motivada pela tradição do êxodo (cf. Dt 5,15). O assentamento de YHWH é seguro (cf. Gn 39,16; Ex 16,23-24; 1Rs 5,18), em contraste com a angústia da loucura (cf. Pr 29,9; Ecl 4,6; 9,17), e permite que as ovelhas se sintam tranquilas como quando guiadas por seu pastor (cf. S1 23,2) ${ }^{578}$

O mal será assentado sobre sua "base" (מְכָוֹנָה), no v.11d, "lugar", "local", "alicerces". ${ }^{579}$ O substantivo construto מִכנוֹנָ, com sufixo em terceira pessoa feminino singular, concorda com o substantivo feminino singular imediatamente anterior, o "efá" (אֵֵפָָ), no v.10b. Portanto, o efá será assentado sobre sua base.

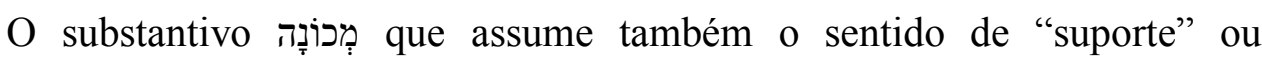
"fundamento", parece estar associado a outros vocábulos utilizados na remoção. Se forem colocados lado a lado, estes vocábulos com seus respectivos significados apontam para um único sentido da remoção:

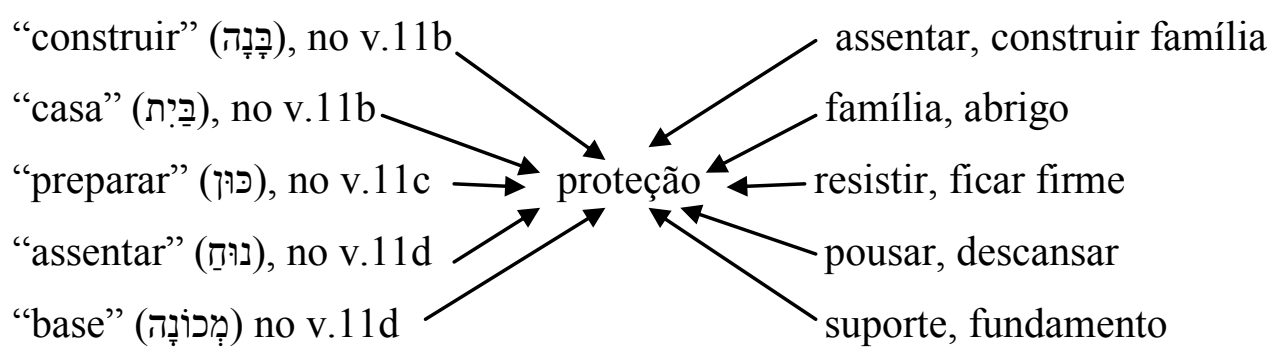

A remoção não envolve destruição ou morte, somente exílio, e será feita com cuidado amoroso. Qual é, portanto, o objetivo da remoção meticulosa e esmerada? Os textos bíblicos apresentam tipos diversos de remoções do mal, em nada semelhantes à remoção do efá: a) lança o pecado no fundo do mar (cf. Mq $7,19)$; b) toca nos lábios do profeta para remover sua iniquidade e perdoa seu pecado (cf Is 6,7); c) perdoa e protege das ameaças contra a vida (cf. Sl 103,2); d) lança fora da cidade em rituais de purificação e expiação (cf. Lv 14,2-9; 33-53); e) troca as vestes sujas de Josué por roupa de festa (cf. Zc 3,4).

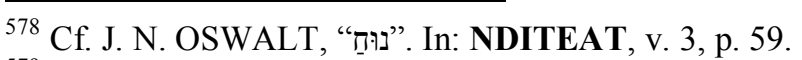

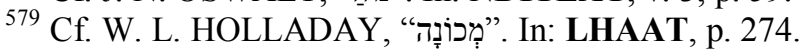


A extraordinária remoção do mal, para reconciliar e unir a comunidade em torno de YHWH e da lei, difere de qualquer punição conhecida nos textos bíblicos. O mal está sendo removido para Senaar para que a comunidade possa se reestruturar e organizar na fé em YHWH. O fim do exílio tornaria possível o recomeço para determinados grupos da comunidade, como parte do plano divino de salvação, que na punição não subverte de forma radical o entendimento do homem do passado e o atual.

Mudanças já vinham ocorrendo no passado, quando o profeta Ezequiel fez uma revisão da retribuição através das palavras de YHWH, num tempo difícil de incertezas com o exílio da Babilônia (cf. Ez 18,1-4). ${ }^{580}$

Com sua visão profética, Ezequiel retirou de YHWH a atribuição original da doutrina e a recolocou como sabedoria popular, evitando que uma instrução divina fosse derrubada, seguindo um preceito já existente de responsabilidade individual (cf. Dt 24,16). ${ }^{581}$ Se no passado Ezequiel, com sua visão profética, inovou e alterou práticas correntes, e com elas inaugurou um novo regime moral e religioso, porque não o faria Zacarias com sua visão profética, quase um século depois? Novos tempos no pós-exílio trouxeram novas palavras de YHWH (cf. Ne 9,17).

Há quem pense que a remoção seria a eliminação da prática da idolatria que deveria ser definitivamente abolida de Judá para que YHWH retornasse a Jerusalém (cf. Zc 2,16). A idolatria no retorno seria prática residual que permaneceu após longa história de contaminação cúltica na comunidade. ${ }^{582}$

Contudo, Zc 5,5-11 é uma denúncia muito mais genérica das relações humanas na comunidade, completando as denúncias específicas de Zc 5,1-4. A remoção tem o sentido de um ritual que, a exemplo dos ritos de purificação do bode levado sozinho ao deserto (cf. Lv 16,21-22), reconcilia e evita a morte e a destruição das vítimas e a desagregação da comunidade. Neste rito de remoção estão representados os que vigiam e denunciam os irmãos aos governantes, em detrimento da própria comunidade (o "olho deles em toda a terra"); os que realizam transações injustas, prejudicando o pobre e necessitado (o "efá", o "disco", a "pedra" e o "chumbo"); o mal genérico dentro da comunidade (a

\footnotetext{
${ }^{580}$ Cf. B. M. LEVINSON, Revisão legal e renovação religiosa no antigo Israel, p. 35-41.5261.71-82.

${ }^{581}$ Cf. T. CRAVEN, "Ezequiel”, Comentário bíblico, p. 67-87.

${ }^{582}$ Cf. C. L. MEYERS; E. M. MEYERS, Haggai, Zechariah 1- 8, p. 314.
} 
“iniquidade"); a mulher, que não se enquadra no padrão ideológico das correntes que pretendem a santidade com ideias de exclusão e pertença ("uma mulher sentada no meio do efá").

$\mathrm{O}$ rito de remoção da impureza da comunidade se torna um ato de misericórdia divina, Senaar é um lugar próximo, de onde o transgressor pode voltar a qualquer momento, onde "toda a terra repousa e está tranquila" (cf. Zc 1,11). Rituais e cerimônias servem para canalizar a violência da sociedade, impossível de erradicar, e onde a vítima seria sacrificada.

O sacrifício pelo pecado (cf. Lv 8) visa a eliminar a impureza (pecado) e restabelecer a pessoa em sua integralidade, ou seja, em suas relações com YHWH e com os outros. O pecado é mais uma situação de "estado" que de intenção, e precisa do perdão divino (cf. Gn 12,10-20; 1Sm 4-5). A remoção é uma espécie de sacrifício ritual que corrige uma situação anômala. ${ }^{583}$

As impurezas provocadas por relações injustas precisavam ser estancadas. Nesse sentido, a remoção é um anúncio de juízo que aponta as consequências futuras das ações do presente. A remoção é o meio pedagógico divino apresentado de antemão para a purificação da comunidade. YHWH aguarda a conversão com misericórdia, pois se ele permitiu que o povo voltasse à terra, para reconstrução do Templo e retomada da atividade cúltica, sem aniquilação total, não o fará agora. Para aguardar a conversão, YHWH oferece uma casa (בָּיָּי) a ser construída

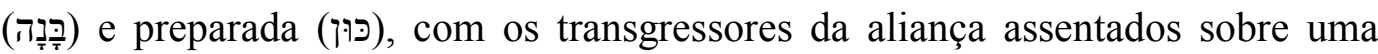
base, as bases de uma família e da proteção. ${ }^{584}$

Zacarias, de origem sacerdotal, diretamente influenciado por concepções restauradoras das escolas dos profetas Dêutero Isaías e Ezequiel, apresentou a coroação simbólica do sumo sacerdote Josué, um descendente davídico, e Zorobabel (cf. Zc 6,9-14), que historicamente jamais se concretizou. Imaginou o fim das disputas por propriedades entre os irmãos (cf. Zc 5,1-4) e anunciou que toda iniquidade seria eliminada (cf. Zc 5,5-11). A transformação visava a uma mudança de direção que levaria todas as nações a se converterem a YHWH (cf. Zc 8,20-23), na qual Jerusalém seria o centro universal da salvação. ${ }^{585}$

\footnotetext{
${ }^{583}$ Cf. J.-L. SKA, O canteiro do Pentateuco, p. 247-251.

${ }^{584}$ M. L. C. LIMA, Mensageiros de Deus: profetas e profecias no Antigo Israel, p. 113-133.

585 Segundo R. ALBERTZ (Historia de la religión de Israel em tiempos del Antiguo
}

Testamento, p. 590-591), com o Império Persa cada vez mais consolidado, é possível que 
A profecia de Zacarias, por um lado, servia para animar o povo, por outro, assustava-o, pois as profecias poderiam nunca se realizar, com o Império Persa cada vez mais consolidado. Assim, é possível que Zacarias, diante desse conflito, se visse obrigado a justificar sua mensagem (cf. Zc 2,13b.15b; 4,9b; 6,15a $\beta$ ). ${ }^{586}$

Zacarias tenha acomodado sua mensagem justificando-a contra dúvidas que surgiram sobre a legitimidade de sua profecia (cf. Zc 2,13b.15b; 4,9b; 6,15aß).

${ }^{586} \mathrm{Cf}$. R. ALBERTZ, Historia de la religión de Israel em tiempos del Antiguo Testamento, p. $590-591$. 


\section{Conclusão}

O objetivo do estudo de Zc 5,5-11 não pretendeu ser uma defesa da teologia do protagonismo da mulher, contudo o caminho percorrido fez com que essa perspectiva fosse assumida com as descobertas a respeito da tendência misógina na interpretação da visão, que atribui à mulher a imagem do pecado. Essa tem sido a tendência interpretativa das últimas décadas, que imprime à mulher uma imagem inexoravelmente negativa, desconectada da teologia feminista que redescobriu o papel das mulheres na teologia, na Igreja e na sociedade.

O status quaestionis mostrou que as interpretações da visão das últimas décadas se apoiaram nas leituras da LXX e de Marenof (1932). A LXX leu o

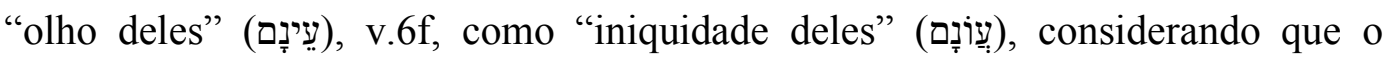
vocábulo "iniquidade", em hebraico (עָוֹ), teria sofrido um desgaste textual, fazendo o waw parecer um yod, transformando "iniquidade" em "olho" (עַ). Marenof associou o sufixo de "olho deles" à visibilidade do efá (v.6d), que seria a casa do topo de um zigurate ("E-pa”), sem qualquer relação com uma vasilha de medida de grãos.

A maioria das interpretações vistas considerou tratar-se de denúncia de idolatria: a mulher no efá seria uma deusa, o efá um santuário e a casa um templo. No entanto, o $\mathrm{M}^{\mathrm{L}}$ reflete claramente o contexto e, hoje, já se sabe que o vocábulo "efá" ("אֵיפָּ") deriva da fonte egípcia ('êpâ) e é também um vasilhame de medição. O que havia sido intuído inicialmente se confirmou com as pesquisas, observa-se uma insistência em atribuir uma imagem negativa à mulher, ligando somente ela, como elemento da visão, ao pecado, uma tendência reducionista que empobrece a mensagem divina e despreza os outros elementos da visão.

Zc 5,5-11, a sétima visão do profeta Zacarias, é muito mais ampla, comparável a um ato cênico de imagens extraordinárias, formada por prólogo, núcleo, com duas cenas, e desfecho. Zc 5,5-11 é uma unidade literária com nexo, coesa e independente.

No prólogo (v.5a-6f), o mensageiro convida o profeta a levantar os olhos e ver o que está sendo desvelado. Com o efá e o olho deles revelados, na primeira cena (v.7a-8d), um disco de chumbo é levantado para descortinar uma mulher 
sentada no meio do efá e, depois, uma pedra de chumbo é lançada em sua abertura.

$\mathrm{Na}$ segunda cena (v.9a-9f), o próprio profeta levanta os olhos e vê a surpreendente imagem de duas mulheres com asas de cegonha, o vento em suas asas levantando o efá entre a terra e os céus. O profeta quer saber o destino do efá (v.10a-10b) e o mensageiro informa além do indagado (v.10c-11d), dizendo que, em Senaar, uma casa será construída e será preparada, e o efá será assentado sobre sua base.

O livro de Zc 1-8 possui três partes, uma introdução com apelo à conversão (Zc 1,1-6), uma coleção de oito visões (Zc 1,7-6,15) e as mensagens de jejum (Zc 7-8). Cada uma das seções apresenta a mensagem divina para a nova era: a primeira, uma convocação para que o povo volte a YHWH e reconstrua com Ele uma nova aliança; a segunda, em estrutura quiástica, o compartilhamento da liderança da comunidade na forma de um governo diárquico, com Josué e Zorobabel; a terceira repete a estrutura quiástica na conclamação para o cumprimento da aliança. Zc 5,5-11, na primeira cena, outro quiasmo aponta o grande problema da comunidade, a iniquidade, que deve ser removida para que se realize o desejo de YHWH de relações éticas e justas.

As três fórmulas de datação que encabeçam as três seções de Zc 1-8 (Zc $1,1.7 ; 7,1)$ indicam que a palavra de YHWH foi entregue ao profeta em três datas distintas, 520 a.C., 519 a.C. e 518 a.C., respectivamente. Em um esforço para datar Zc 5,5-11, percebe-se que esta visão ocorreu em 519 a.C. quando a coleção das visões foi entregue ao profeta, no primeiro tempo da reconstrução do templo.

As fórmulas de datação mostram uma preocupação com a descendência sacerdotal do profeta (cf. Ne 12,4.16), provavelmente para enfatizar a importância do sacerdócio como função herdada, uma função extirpada com o exílio e que no pós-exílio buscou ocupar uma posição predominante na sociedade.

Contudo, o ciclo de visões mostra que Zacarias possuía uma ideia exclusiva para a restauração da comunidade na nova era: a) seria de âmbito cósmico (Zc 1,11; 3,9); b) os seres humanos deveriam aguardar a ação de YHWH e de seus agentes (Zc 5,1-4;5,5-11); c) Jerusalém não teria muros e seria densamente povoada (Zc 2,1-4); d) YHWH não ficaria limitado ao Templo, pois Ele mesmo seria um muro de fogo e glória no meio da cidade (Zc 2,5-9); e) não haveria liderança sacerdotal, nem degradados nem não degradados e, sem 
hierarquia, a atividade sacerdotal começaria com Josué, que deveria antes ser purificado para isso (Zc 3,1-7); e) o governo seria diárquico com Josué e Zorobabel (Zc 6,9-15); f) a sociedade, não tão perfeita, viveria a nova ordem que incluiria os que violaram a aliança e ainda permaneciam impunes (Zc 5,1-4).

O fato de Zacarias não ser citado por Esdras na cerimônia de dedicação do templo, em 515 a.C. (cf. Esd 5,2; 6,13-22), e a ausência de oráculos na sexta e sétima visões indicam que estas profecias desagradaram os reformistas excludentes, por terem deixado a questão dos bens e propriedades (cf. Zc 5,1-4) e a da mulher (cf. Zc 5,5-11) nas mãos de YHWH. Provavelmente esperavam uma solução drástica, semelhante à de Esdras, que determinou a expulsão das esposas estrangeiras e de seus filhos da comunidade (cf. Esd 10,3).

A visão, no entanto, apenas remove tudo que simbolizava relações rompidas da comunidade, semelhante ao rito levítico do bode expiatório (cf. Lv 16,1-34). A remoção em Zc 5,5-11 permitiria a renovação da aliança, a união de YHWH com o povo e a reconciliação dos membros da comunidade em prol de uma vida de santidade. Contudo, essa remoção, em vez de um abandono no deserto, trabalha com elementos que indicam um cuidado amoroso de YHWH.

Zc 5,5-11 ocorre no contexto de domínio do Império Persa, quando ocorreram os primeiros retornos e foram iniciadas as obras de reconstrução do Templo e o processo de reorganização da sociedade judaica para a nova era. Os retornos tiveram início após a conquista da Babilônia, em 538 a.C., quando Ciro, o rei persa, permitiu que os povos exilados retornassem às suas terras e cultuassem seus deuses. Os que retornavam constituíam grupos oriundos de uma variedade de correntes originadas no exílio, cujo ponto comum era a esperança de uma restauração davídica (cf. Is 23,5-6; Jr 30,21; Ez 34,23; 37,24).

Nem todos retornaram da diáspora e, na Judá do pós-exílio, cercada de províncias não judaicas, nem todos eram judeus. Além disso, após décadas de convívio com outros povos, os exilados que retornaram para reconstruir o Templo e reorganizar a comunidade em torno do Templo e do culto a YHWH formavam uma população de culturas diversificadas. A população assim formada, grupos de grandes proprietários, grupos independentes e economicamente poderosos, famílias sacerdotais e o povo, pobre, que permanecera na terra, deu origem a diversas correntes, com diferentes ideologias. 
Os grupos disputavam a liderança da comunidade, e não eram grupos apenas de religião (cf. Dt 18,9-13; Zc 13,1-6). ${ }^{587}$ As reivindicações ortodoxas da tradição bíblica mostram, apenas sutilmente, as múltiplas correntes religiosas, as tradições recebidas e os grupamentos sociais e regionais. ${ }^{588}$ A comunidade do retorno estava dividida entre os que se sentiam impregnados de ideais proféticos, fiéis à religião e às tradições (os exilados, a elite), e os da terra (a maioria), que podem ser vistos apenas na sombra dos textos bíblicos. ${ }^{589}$

Os enfrentamentos resultaram numa dialética singular em que, se por um lado possibilitou implantar uma organização integradora da sociedade, por outro liberou uma série de forças desintegradoras, cujas ideias de exclusão e pertença deixavam uma parte do povo à beira da marginalização, com uma séria ameaça à unidade de uma vida em comum. ${ }^{590}$

As tensões sociais internas e o brutal conflito de interesses dentro da comunidade judaica potencializaram-se com a cobrança de tributos elevados pelo Império Persa, que se utilizava desse artifício como forma de impor seu domínio aos povos conquistados. Nesse contexto, com dificuldades para a realização das esperanças davídicas, agia um grupo empenhado em uma separação social e religiosa, fechado aos que eram considerados menos ortodoxos e impuros (cf. Ag 2,10-14), e outro que convivia harmoniosamente com vizinhos e imigrantes.

A mulher no efá é a mulher deste contexto de disputas, literalmente uma mulher, a estrangeira ou a judia, a da terra ou a que retornou, vinda da Babilônia ou de outros lugares. Esta mulher, porque não se submete, está sentada no meio do efá, presa por uma tampa de chumbo. A feminilidade e a masculinidade, no sentido de um comportamento e identidade, é uma construção cultural, fruto de uma época, e a mulher no efá é a mulher moldada na realidade de décadas de exílio, que assustava os membros da comunidade.

O Antigo Testamento é o relato de várias vozes onde diferentes pontos de vista foram reconciliados. Circunstâncias novas pediam adaptação, atualizações em relação às leis, às relações familiares e de trabalho e à regularização de bens e

\footnotetext{
${ }^{587}$ Cf. E. S. GERSTENBERGER, Israel no tempo dos persas, p.129-130.

588 Cf. E. S. GERSTENBERGER, Israel no tempo dos persas, p.129-130; R. ALBERTZ, Historia de la religión de Israel em tiempos del Antiguo Testamento, p. 576-588; J. BRIGHT, História de Israel, p. 493-499.497-499.

${ }^{589}$ Para J.-L. SKA (O canteiro do Pentateuco, p.184) "na Bíblia, só raramente se ouve a voz da maioria, do povo, que tinha outras preocupações e outras maneiras de resolver seus problemas".

${ }_{590}$ Cf. R. ALBERTZ, Historia de la religión de Israel em tiempos del Antiguo Testamento, p. 576-588.
} 
propriedades. Embora o sistema jurídico estivesse em mãos masculinas, dirigido aos homens, sujeitos do direito, as mulheres eram mães, esposas, irmãs, filhas, cunhadas. Nesse sentido, os direitos da mulher se não são citados explicitamente o são implicitamente, em "linguagem inclusiva" como acontece com normas jurídicas modernas. ${ }^{591}$

Além disso, algumas narrativas bíblicas revelam que havia uma práxis diferente baseada no direito consuetudinário e nos costumes dos "povos da terra", evidenciando que havia um movimento que, se não era "pró-mulher", também não era essencialmente masculino e exclusivista.

Nesse ambiente plural, a mulher no efá emerge dos textos bíblicos da época. Ela está sendo submetida sentada no meio do efá, figuradamente, exatamente porque não se submete socialmente, ela não é propriedade do homem, ela tem voz e opinião e, por isso, incomoda, influencia e provoca narrativas positivas que indicam uma posição contrária à imagem interpretada.

As mulheres, como as parteiras Sefra e Fua (cf. Ex 1,15-22), a mulher que gerou Moisés (cf. Ex 2,1-3), a filha do faraó (cf. Ex 2,6.10) e a irmã de Moisés (cf. Ex 2,4.8-9) eram capazes de enfrentar o poder estabelecido; ou como Rute e Noemi, que fizeram valer o direito de Rute ser resgatada por Booz (cf. Dt 25,5-6; Rt 3,12-13; 4,1-11).

As mulheres tinham seus direitos protegidos de possíveis abusos no uso do divórcio como prática legal de adultério (cf. Dt 24,1-4) (92 $^{52}$ de falsas acusações de adultério (cf. Dt 22,13-21). E, se a lei não protegia a mulher, ela mesma defendia seus direitos, como o fizeram Resfa, que reagiu e exigiu respeito, fazendo seu direito prevalecer à "lei", para enterrar seus filhos mortos (cf. 2Sm 21,1-14), e Tamar, a canaanita, que engravidou de seu sogro, Judá, que não fizera cumprir a lei do levirato (cf. Gn 38,1-27; Dt 25,5-10).

Textos bíblicos testemunham que a mulher não era mera propriedade do marido: a) Raquel, filha de Labão, conduzia rebanhos (cf. Gn 29,6); b) Rebeca buscava água sozinha (cf. Gn 24,13; Ex 2,16-22; 1Sm 9,11); c) Rute apanhava espigas no campo atrás de segadores (cf. Rt 2,2-7); d) Dina, filha de Lia, visitava

\footnotetext{
${ }^{591}$ São exemplos de normas inclusivas as que determinam guardar o sábado (Ex 20,8; 23,12), participação em festas e sacrifícios (cf. Dt 16,11.14.18), "homicídios" (cf. Ex 21,22-25), "restituição" (cf. Nm 5,5.8), de transgressão da aliança com YHWH (cf. Dt 13,7; 17,2).

${ }^{592}$ HOPE, L. J., Deuteronômio. In: BERGANT, D., KARRIS, R. J. (orgs.), Comentário Bíblico. São Paulo: Loyola, 1989, p. 207
} 
estrangeiros (cf. Gn 34,1-31); e) audaciosas, podiam tirar o sono do pai (cf. Eclo 42,9); f) agiam para realizar a honra de ser mãe e cooperar com a promessa divina de uma posteridade numerosa para Israel (cf. Gn 26,4) como o fizeram Sara (cf. Gn 15,1-6), Raquel e Lia (Gn 29,31-35; 30,14-24; 31,9-13); g) podiam ter autoridade sobre o marido, como Sara que mandou Abraão expulsar Agar e Ismael para o deserto (cf. Gn 21,8-14); podiam salvar a vida de um grande líder e herói do povo da aliança, como Séfora, que salvou a de Moisés (cf. Ex 4,24-26); i) como Hulda, podiam assumir autoridade profética e mediar a Palavra de YHWH (cf. 2Rs 22,16-20); j) eram chamadas "profetizas" (cf. Ex 15,20; Jz 4,4; 2Rs 22,14; Ne 6,14); k) tinham pensamento próprio sobre o mundo (cf. Pr 31,26$29)^{593}$; 1) como Abigail, agiam para impedir derramamento de sangue (cf. 1Sm 25,25); m) como Débora, a profetiza, podiam administrar a justiça em nome de YHWH (cf. Jz 4,4-9); n) eram ativas na educação dos filhos, na socialização religiosa dos homens e na transmissão das tradições da Torá (cf. Pr 1,8; Dt 29,912); o) como foi feito para Eliseu, podiam construir um quarto em sua casa e mobiliá-lo para seu hóspede (cf. 2Rs 4,8-10); p) podiam examinar e comprar um terreno com seu dinheiro e plantar uma vinha, obtendo sucesso nos negócios (cf. $\operatorname{Pr} 31,16.18)$; q) supõe-se até que, como as cananeias, pudessem dispor de propriedades; r) como Shelomit (citada em 1Cr 3,19), firmar compromissos ou servir de testemunha, o que foi atestado pela arqueologia.

A suspeição e a desvalorização da mulher são mais evidentes no pósexílio, o que coincide com a questão dos casamentos mistos, envolvendo bens e propriedades. Passagens bíblicas apresentam adaptações sobre o patrimônio das filhas, mostrando preocupação em retê-lo dentro das tribos (cf. Nm 27,1-11; Nm 36,1-12). Esdras e Neemias evidenciam essa preocupação ao incluírem cananeus, heteus, ferezeus, jebuseus, amonitas, moabitas, egípcios e amorreus como "povos da terra" (cf. Esd 9,1-3; 10,10-15; Ne 13,23-30), sete destes incluídos porque eram antigos ocupantes de Canaã quando os israelitas lá chegaram.

Os casamentos mistos preocupavam de fato: a) primeiro, porque geravam um grande número de mulheres judias abandonadas por causa da preferência por mulheres estrangeiras, cuja união atrativa possibilitava ascensão social devido à

\footnotetext{
${ }^{593}$ A mulher ensina com sabedoria e misericórdia e, com isso, combina os ideais de um profeta e de um sábio, uma vez que a misericórdia é o conceito central da teologia da aliança dos profetas (BOADT, L. E., "Provérbios". In: BERGANT, D., KARRIS, R. J. (orgs.), Comentário bíblico, v. 2. São Paulo: Loyola, p. 235-259).
} 
condição econômica do cônjuge mulher e aos dotes oferecidos aos noivos (cf. Ne $6,18 ; 13,28)$; b) segundo, porque os bens e propriedades, em caso de divórcio, podiam sair das mãos da comunidade judaica, pois o marido não poderia reclamar o "dote pago à família da noiva" (מָרֵ), a mulher receberia uma compensação pelo divórcio (segundo o código de Hamurabi) e ainda conservaria o que levara para o casamento; c) terceiro, porque interferiam no desejo de pureza cultual e de uma identidade de linhagem de sangue puro para o povo judeu.

Seguidos exílios levaram ao rompimento das relações familiares e ao abandono de propriedades, ameaçando gravemente a família como base social. Os casamentos mistos se tornaram uma realidade para o povo de Israel quando foi obrigado a viver em outras terras, com outros povos e com outras culturas. Com o retorno, os casamentos com estrangeiros continuaram a acontecer, pois Judá estava cercada de províncias não judaicas, e nem todos os judeus se assentaram em Judá e nem todos os moradores de Judá eram judeus. Miqueias denuncia os casamentos mistos que transgrediam a aliança e os laços que unem a comunidade (cf. Ml 2,11; cf. também Esd 9-10; Ne 13,23-27), o profeta fala em decepção e traição na família (cf. Mq 7,5-7). ${ }^{594}$

A autoridade civil estava enfraquecida e os próprios sacerdotes contraíam matrimônios mistos, por isso não seriam eles que coibiriam os abusos morais e sociais (cf. Ml 2,10-16; Esd 10,18-44). Paradoxalmente, a classe dominante não ficou feliz com a solução dada à mulher na visão, uma mulher com mais autonomia e que invadia a santidade da comunidade, comprometendo a ideia de pureza e ameaçando a terra prometida.

Estas informações são ignoradas e a interpretação da visão segue uma longa tradição de reforçar o aspecto misógino, que não encontra raiz no texto e ainda insiste em manter a imagem da mulher como afeita ao pecado. Uma visão negativa da figura da mulher pode mudar completamente a mensagem de Zc 5,5$11 .^{595}$

Sutis reivindicações em prol das ações das mulheres na Bíblia são ofuscadas por uma posição preconceituosa do status da mulher até os dias de hoje. A oposição à mulher nos textos bíblicos, em vez de refletir uma situação de

\footnotetext{
${ }^{594}$ Cf. R. KESSLER, História Social do antigo Israel, p. 173-176.

${ }^{595}$ Cf. H. SCHÜNGEL-STRAUMANN, H., Die Frau Am Anfang Eva und die Folgen, Exegese in unserer Zeit. Münster/Hanburg/London: LIT, 1989, p. 73.
} 
submissão, indica, ao contrário, uma independência que exigia limites. Zc 5,5-11 desmistifica ideias preconcebidas de submissão e propriedade da mulher e ironiza aqueles que a queriam submetida e prisioneira ao juntar a mulher, na remoção do efá, a tudo que representava a classe rica e privilegiada, exatamente aqueles que pregavam exclusão e pertença enquanto exploravam os pobres.

O efá, o olho deles, o disco, a pedra e o chumbo são símbolos destas explorações e representam as rupturas das relações com YHWH e com o próximo. O efá, uma medida de grão de cereais (cf. Lv 5,11; $1 \mathrm{Sm} \mathrm{17,17;} \mathrm{Rt} \mathrm{2,17),} \mathrm{foi}$ sempre preocupação do povo da aliança que acreditava que uma sociedade só seria coesa se praticasse transações comerciais honestas (cf. Dt 25,13-16). Numa época de miséria, denunciada por Ageu como de desequilíbrio de salários e preços (cf. Ag 1,1.6), por Amós como de práticas ilícitas no comércio (cf. Am 8,5), e por Zacarias como de recomeço modesto $(\mathrm{cf}$. Zc 4,10$)$ e de disputas por propriedades (cf. Zc 5,1-4), o efá era uma questão de vida ou morte. Nesse sentido, o efá inicia e termina o relato e é citado cinco vezes, explicitamente (vv.6d.7b.8c.9f.10b), e três, implicitamente (vv.8d.11bd).

Disco, pedra e chumbo, símbolos de unidades de peso ou valor utilizadas em transações comerciais, atingiam sobremaneira o pobre, que ainda precisava enfrentar: a) a demora na conclusão das obras do Templo; b) a cobrança na participação nas obras do Templo; c) as disputas por propriedades deixadas para trás no exílio e agora reivindicadas pelos retornados; d) pesadas cobranças de impostos pelo Império Persa; e) cunhagem de moeda iniciada no tempo de Dario; f) e, ainda, a exploração pela classe rica que se aproveitava da situação para enriquecer mais e mais, levando o pobre ao último estágio da escala social.

Neemias cita empréstimos com cobrança de juros (cf. Ne 5,6-13), e o

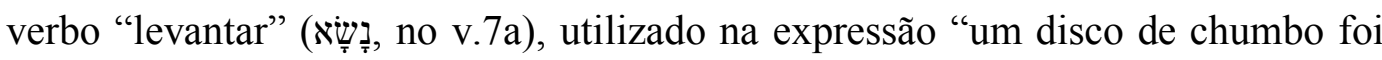
levantado", lembra o sentido desse verbo de "conceder empréstimo ou penhor".

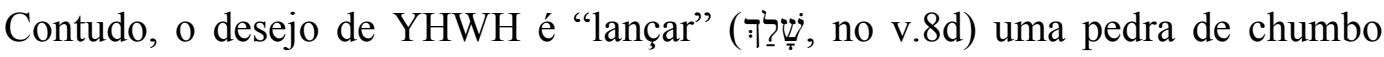
sobre o efá, pondo fim às injustiças sociais.

As classes ricas, longe de se solidarizarem com os irmãos miseráveis, exploravam-nos mais e mais, aproveitando-se das mudanças e esquecendo-se das leis (cf. Ex 21,1-11). Muitos, com ambição de dinheiro e poder, se tornavam o "olho deles", um esquema de vigilância do Império Persa para, "em toda a terra" (v.6f), garantir a arrecadação de impostos e o controle contra insurreições. 
O Império Persa mantinha domínio sobre Judá através de uma política tributária severa. A cobrança de impostos foi introduzida por Dario I (522-484 a.C.) e obrigava cada satrapia a pagar, anualmente, uma determinada soma em metal precioso ao império. Isto agravava ainda mais a situação do pobre porque não levava em conta a situação de crise econômica ou o fato de a região não possuir reservas de prata, necessárias para os pagamentos. ${ }^{596}$

A lei que combatia o empobrecimento da população e o abuso daqueles que enriqueciam explorando o irmão não estava sendo cumprida no pós-exílio (cf. Ex 21,1-11), o que deixava o pobre entregue à própria sorte. ${ }^{597} \mathrm{~A}$ menção a elementos da economia, efá, pedra, disco e chumbo (vv.7a.8d), se configura grande ironia associada à presença da mulher sentada dentro do efá (v.7a).

A mulher no efá é uma questão de identidade de grupo, e não de misoginia. Essa é a questão retratada na crítica aos casamentos mistos. A situação da mulher não piorou no pós-exílio. A valorização da família e consequentemente a valorização da mulher foram elementos de continuidade que se contrapunham às diferentes correntes ideológicas como elementos de descontinuidade, favorecendo um quadro de conflitos de relacionamento.

Zc 5,5-11 é o restabelecimento das relações entre os membros da comunidade desejada por YHWH. O tamanho da mulher em relação ao minúsculo espaço do efá apresenta a dimensão simbólica do problema do mal na comunidade, um mal muito maior do que o desvio que se pretendia conter. ${ }^{598} \mathrm{~A}$ comunidade judaica do pós-exílio investiu na criação das relações fraternas; teólogos deste período colocaram a justiça a serviço do amor fraternal, com vistas ao convívio social equânime, semelhante ao da família (cf. Sl 50,5; 65,5-6; 133,1). ${ }^{599}$ A mulher sentada no meio do efá quer apenas mostrar que uma renovação espiritual seria possível.

Ironicamente, essa renovação ocorre pelas mãos de duas mulheres, e com asas de cegonha. A extraordinária imagem de duas mulheres com asas de cegonha e "vento" (רוּח) em suas asas, levantando o efá entre a terra e os céus é ironia fina que mistura, em movimento onomatopeico, o divino e o impuro, o masculino e o

\footnotetext{
${ }^{596}$ Cf. R. KESSLER, História Social do antigo Israel, p. 184-191.

${ }^{597}$ Cf. E. S. GERSTENBERGER, Israel no tempo dos persas, p. 121-126.

598 Cf. M. E. MILLS, Urban Imagination in Biblical Prophecy. New York/London/New Delhi/Sydney: Bloomsbury, 2012, p. 156.

${ }^{599}$ Cf. E. S. GERSTENBERGER, Israel no tempo dos persas, p. 129-130.
} 
feminino, em tarefa e espaço divinos, uma ironia com as relações humanas que se mostravam excludentes, injustas e antiéticas.

Os diálogos, as discrepâncias de gênero e o desfecho da visão, considerados estranhos ao texto, são recursos linguísticos e teológicos que fazem parte de uma habilidade pedagógica em apontar solução. Zc 5,5-11 é uma reflexão teológica, uma pedagogia do amor divino, uma solução fraterna para os problemas de relacionamento da comunidade.

O transporte feito por duas mulheres, e com asas de cegonha, enfatiza a pedagogia divina que aponta para o caminho da inclusão social, das relações sociais justas e da solidariedade necessários à vida, principalmente em tempos difíceis. A visão mostra que a participação solidária pode vir de mulheres com asas como de cegonhas com vento, o Espírito de Deus em suas asas, e despreza considerações negativas a respeito da figura feminina e da impureza da cegonha (cf. Lv 11,19; Nm 5,15).

O que importava era a vida com YHWH e o outro (cf. Sl 40,6-10; 55,13$15 ; 88,9.19)$. O isolamento aterrorizava e desencorajava. O indivíduo era membro de uma família (casa), tribo, clã e nação e, nestas estruturas, não se perdia nem submergia, sua existência era real, fora dela era nada (cf. 1Sm 25,29).

Esse é o extraordinário sentido de o efá estar sendo levado para Senaar. Os

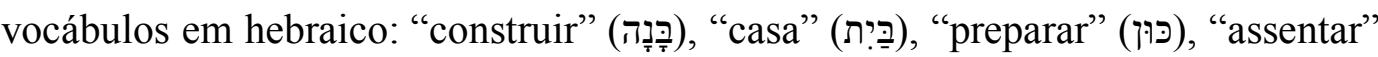
(נמוּח) e "base" (מְכוֹנָה) apontam para um ambiente acolhedor, firme, seguro e protegido, de onde o indivíduo poderá "voltar" (שוּב) para YHWH (cf. Zc 1,3).

Eli Assis, em seu artigo "Zechariah's Vision of the Ephah (Zech. 5:5-11)" (2016) interpreta a mulher como uma representação dos samaritanos. Segundo o autor, uma mulher foi colocada no efá (v.7b) para representar a iniquidade dos

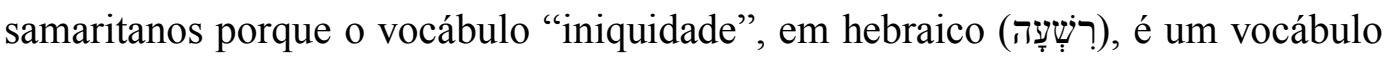
feminino. Para Eli Assis, essa interpretação resolve o problema do intrigante desfecho com uma casa construída em Senaar e os samaritanos retornando ao lugar de onde vieram, a Babilônia.

Eli Assis considerou os samaritanos o único e grave problema de relacionamento na comunidade. Do ponto de vista sacerdotal, os samaritanos possuíam descendência comum e a mesma fé em YHWH, o que os tornava aliados naturais dos judeus. Escritos encontrados em Qumran indicam que, 
embora discordassem em algumas questões, o Pentateuco uniu judeus e samaritanos com o objetivo de reorganizar a comunidade. ${ }^{600}$

Como Josué teve suas vestes sujas trocadas para se tornarem adequadas (cf. Zc 3,4), a remoção purificará as relações inadequadas da comunidade. Como Ezequiel fez uma revisão da responsabilidade dos atos do indivíduo (cf. Ez 18,132), Zacarias faz uma revisão da punição, mostrando que YHWH não tem prazer na morte de ninguém. A iniquidade não é definitiva, é um "estado" da pessoa que pode ser "removido" (cf. Zc 1,1-6).

A remoção é sabedoria divina na solução dos problemas, é pedagogia e misericórdia que interrompe o ciclo persecutório da crise da comunidade e a reconcilia. O rito de remoção da iniquidade de dentro da comunidade em Zc 5,511 é um ato de misericórdia divina. Senaar é um lugar de onde o transgressor pode voltar a qualquer momento, pois está inserida no contexto espacial onde "toda a terra repousa e está tranquila" (cf. Zc 1,11) e o universo ordenado e em paz (Zc $6,8)$.

Remover o mal para Senaar cumpre um ritual que serve para canalizar a violência da sociedade, impossível de ser erradicada. Nestes cerimoniais, o transgressor, representado pelo efá, o olho deles, a mulher e disco/pedra de chumbo, seria uma vítima sacrificada, caso não houvesse o ritual.

O sacrifício pelo pecado (cf. Lv 8) visa a eliminar a impureza (pecado) e restabelecer a pessoa em sua integralidade, ou seja, em suas relações com YHWH e com os outros. O pecado é mais uma situação de "estado" que de intenção, e precisa do perdão divino (cf. Gn 12,10-20; 1Sm 4-5). A remoção é um sacrifício ritual que corrige uma situação anômala. ${ }^{601}$

As impurezas provocadas por relações injustas precisavam ser estancadas. Nesse sentido, a remoção é um anúncio de juízo que aponta as consequências futuras das ações do presente, e o meio pedagógico divino apresentado para a purificação da comunidade. Se YHWH permitiu que o povo voltasse à terra e reconstruísse o Templo, retomando as atividades cúlticas, não será agora que aniquilará seu povo. Contudo, YHWH aguarda a conversão e, para isso, oferece

\footnotetext{
${ }^{600}$ Cf. G. N. KNOPPERS, "Parallel Torahs and Inner-Scriptural Interpretation: The Jewish and Samaritan Pentateuchs in Historical Perspective", p. 507-532.

${ }^{601}$ Cf. J.-L. SKA, $O$ canteiro do Pentateuco, p. 247-251.
} 


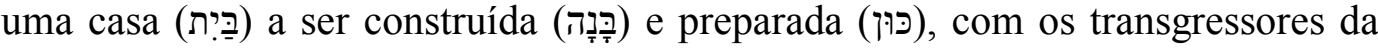
aliança assentados sobre sua base, a base da família e da proteção. ${ }^{602}$

Os termos casa, construir, preparar, base e assentar são práticos e materiais, em oposição irônica a uma linguagem religiosa, para atingir aqueles que corrompem a comunidade e destroem com seus atos sua base sócio-religiosa.

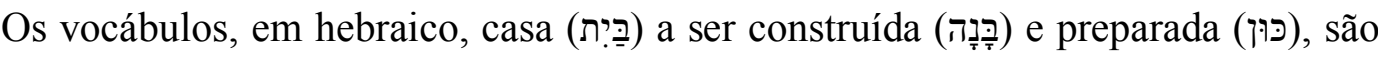
uma ironia porque remetem à formação da família que corre risco de destruição diante de um caos social. Com a casa a ser construída e preparada, YHWH está lembrando que Israel ainda é seu povo eleito que, ao sair do Egito, foi assentado em sua base.

A não destruição faz parte de textos revisados. Não há sentido em destruição, pois o momento exigia controle dos escassos recursos humanos. Os novos tempos requeriam a força e o trabalho de cada pessoa da comunidade, homem e mulher, para a realização das promessas divinas (cf. Zc 2,10-11; 6,15), onde a mulher fosse, realmente, ser complementar ao homem (cf. Gn 1,26). Fazia mais sentido a remoção do "bode expiatório" para um lugar de onde poderia voltar.

A ruptura das relações com YHWH e com o próximo isola o indivíduo e elimina a solidariedade. $\mathrm{O}$ que o judeu procurava era a vida com YHWH e com a comunidade, o contrário seria a morte. Nesse sentido, Zc 5,5-11 é uma mensagem divina para que os deveres de amor e de justiça não sejam relativizados, e de esperança para os iníquos e os necessitados.

A remoção completa o quadro pedagógico divino, sempre pressupondo correspondência entre a ação e o efeito do pecado, o arrependimento e o perdão, como forma de restaurar as relações do homem com Deus e com o próximo. Era um tempo de grandes dificuldades, onde cada um era importante como ser humano e como membro de uma comunidade que se reorganizava.

O profeta apresentou uma teologia nova, com pedagogia em que prevaleceram o amor e a misericórdia divinos, sem eliminar e sem destruir. Protegendo o transgressor, YHWH espera que haja conversão para que restabeleça as relações com Ele e com o outro e integre-se novamente à comunidade. Zc 5,511 é uma mensagem de enorme coragem profética.

\footnotetext{
${ }^{602}$ M. L. C. LIMA, Mensageiros de Deus, p. 113-133.
} 
A remoção na visão reflete o desejo de Deus que as relações humanas sejam éticas e justas (cf. Zc 7,3-14), um Deus que compreende o ser humano na sua fragilidade e ambiguidade e lhe dá liberdade nas escolhas que faz. Em uma leitura mais ampla, pode-se dizer que Zc 5,5-11 antecipa as atitudes, palavras e opções de Jesus Cristo, que revela a imagem de um Deus que se importa com o que parece ser meramente humano (a família, o trabalho, a cultura, a política, etc) e quer mostrar como deve ser o ser humano. É o próprio homem que tem dificuldade de aceitar a misericordiosa divina, pois ele mesmo tem dificuldade em perdoar e, muitas vezes, não perdoa nem a si próprio.

Justamente por essa temática, Zc 5,5-11 abre uma perspectiva para novos estudos relativos à punição divina e para a situação da mulher na teologia, na Igreja e na sociedade. Zc 5,5-11 se insere nos debates sobre a injustiça social e o papel da mulher na sociedade. Os textos bíblicos foram escritos sob a perspectiva dos homens, e a análise interpretativa posterior, tendenciosa, contribuiu para a manutenção de uma situação de inferioridade e uma consequente submissão da mulher. Ações devem ser implementadas com o objetivo de tentar reverter a imagem negativa imputada à mulher ao longo do tempo.

A Palavra de Deus não pode ser utilizada para submeter e violentar. 


\section{8}

\section{REFERÊNCIAS BIBLIOGRÁFICAS}

\section{Dicionários e Léxicos}

ALONSO SCHÖKEL, L., Dicionário Bíblico Hebraico-Português. São Paulo: Paulus, 2010.

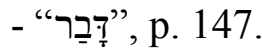

- “הָדָ", p. 176-177.

- “พָָָ", p. 286.

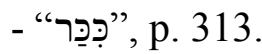

- " "נָָ", p. 414.

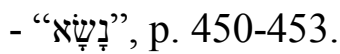

BERLEJUNG, A., FREVEL, C. (orgs.), Dicionário de termos teológicos fundamentais do Antigo e do Novo Testamento. São Paulo: Paulus/Edições Loyola, 2006.

- FREVEL, C., “morte”, p. 316-319.

BIBLE ENCYCLOPEDIAS of Biblical Theological and Ecclesiastical Literature. $<$ https://www.studylight.org/encyclopedias/mse/l/lead.html $>$, Acesso: 30 abr. 2019.

- "chumbo".

BOTTERWECK, G. J., RINGGREN, H., FABRY, H. -J. (Org.), Theological Dictionary of the Old Testament. Michigan: Eerdmans Publishing Co., V. I-XV, 1980-2006.

- PREUSS, H. D., “צָּ", V. VI, p. 231.

- FREEDMAN, D. N.; O’CONNOR, M. P., “"ְְִּרברבים", V. VII, p. 307-319.

- ZOBEL, Hans-Jürgen, “范”, V. II, p. 476-488.

BROWN, F., DRIVER, S. R., BRIGGS C. A., The Brown-Driver-Briggs

Hebrew and English Lexicon. Massachusetts: Hendrickson Publishers Marketing, 2014, p. 552.

COLLINS, J. J., “apocalíptica”. In: LACOSTE, Jean-Yves, Dicionário crítico de Teologia. São Paulo: Paulinas/Loyla, 2004, p. 161-165. 
HARRIS, R. L.; ARCHER, G. L.; Jr. WALTKE, B. K. (Org.), Dicionário Internacional de Teologia do Antigo Testamento. São Paulo: Vida Nova, 2008 .

- ALDEN, R. L., “אֶבֶּ, p. 8-10.

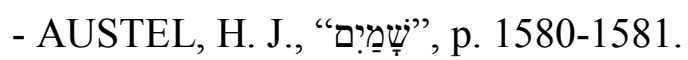

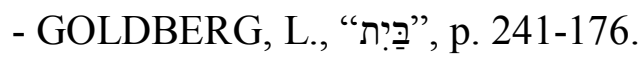

- HAMILTON, V. P., “הฐֶ๊, p. 1203-1204.

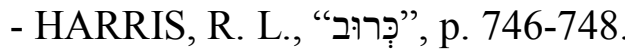

- HARRIS, R. L., “חָדִיד", p. 499.

- HARRIS, R. L., “חסד”, p. 499-503.

- HARRIS, R. L., “כפר", p. 743-744.

- KAISER, W. C., “"ָָָ", p. 809.

- LALDEN, R., “אֶֶֶ”, p. 8-10.

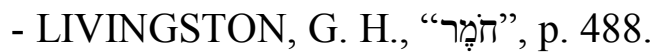

- OSWALT, J. N., “כון”, p. 707-709.

- SCHULTZ, C., “עַיקין", p. 1108-1109.

- SCOTT, J. B., “אֵיפָה”, p. 62.

- WOLF, H., “זֶ?, p. 381.

HOLlaDAY, W. L., Léxico Hebraico e Aramaico do Antigo Testamento. São Paulo: Vida Nova, 1988.

- “הָיכָל", p. 109.

- “" p. 52-53.

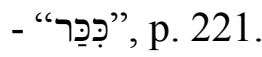

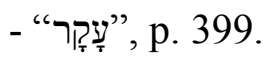

- “ה̄", p. 104.

- “אָדֶ”, p. 12-139.

- “חקְֶָ", p. 157.

- “דָדִיד", p. 158.

- “יָָָ", p. 197-198

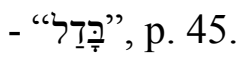

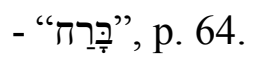

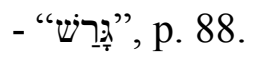

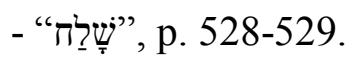

- “"חָסִיזָ", p. 157-158. 
- “"חדר", p. 157-158.

- "חקסֶד", p. 157-158.

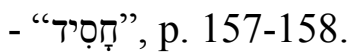

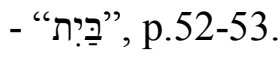

- “"ְְּ? p. 230-231.

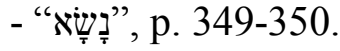

- "סָלָ", p. 364.

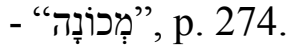

- “מַis", p. 262.

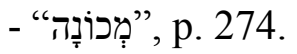

LIMA, M. L. C., "Escatologia”. In: BARRIOCANAL, J. L. (org.), Diccionario del profetismo Bíblico. Burgos: Monte Carmelo, 2007, p. 255-266.

LOUW, J., NIDA E., Léxico Grego-Português do Novo Testamento, baseado em domínios semânticos. Barueri: Sociedade Bíblica do Brasil, 1988.

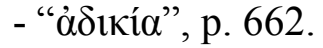

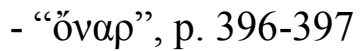

McKENZIE, J. L., Dicionário Bíblico. São Paulo: Paulus, 1978.

- “apocalipse”, p. 49.52.

- “mar", p. 527-529.

- “chumbo", p. 151.

- “querubins", p. 694-995.

- “serafim", p. 791.

- “teofania”, p. 843-844.

SCHÖCKEL, L. A., Dicionário bíblico hebraico-português. São Paulo: Paulus, 1997.

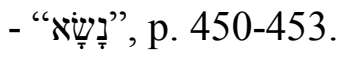

- “נָָ", p. 414.

- " "אַ", p. 39.

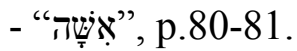

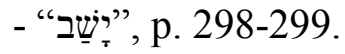

- “הָדָ", p. 176-180.

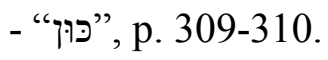

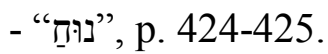


VANGEMEREN, W. A. (Org.), Novo Dicionário Internacional de Teologia e

Exegese do Antigo Testamento. São Paulo: Cultura Cristã, 2011.

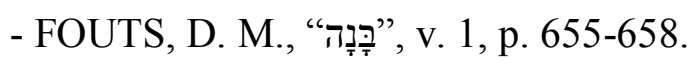

- FULLER, R., "אֵיפָּ", v. 1, p. 373-378.

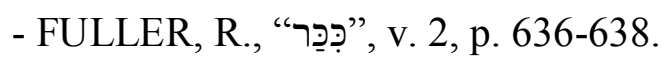

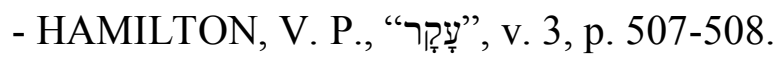

- HARMAN, A. M. “"עִיע", v. 3, p. 390-396.

- HILL, A., "אֶֶֶ”, v. 1, p. 242-243.

- JENSON, P. P., “אַַָ", v. 1, p. 339-341.

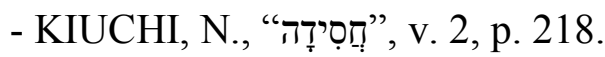

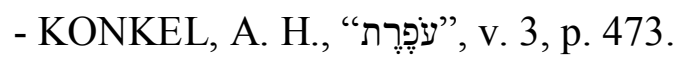

- MARTENS, E. A., “כון", v. 2, p. 615-616.

- MERRIL, E. H., “יָָָָ', v. 2, p. 497-498.

- MERRIL, E. H., “הָרָרָ", v. 1, p. 1006-1009.

- OSWALT, J.N., “"נּּ", v. 4, p. 59

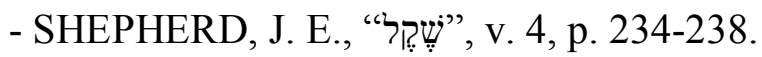

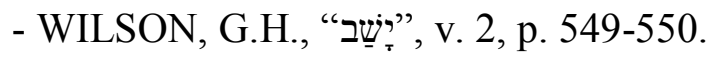

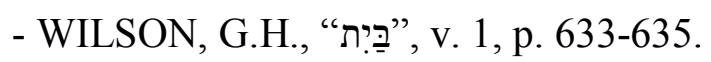

- WRIGHT, C. J. H., “אֶר", v. 1, p. 505-511.

\section{Comentários e livros}

ALBERTZ, R., História de la religion de Israel en tiempos del Antiguo Testamento. Biblioteca de Ciencias Bíblicas Y Orientales. Madrid: Editorial Trota, 1999.

ARMSTRONG, K., Breve história do mito. São Paulo: Companhia das Letras, 2005.

BALDWIN, J. G., Ageu, Zacarias e Malaquias. São Paulo: Vida Nova, 1972.

BARTHÉLEMY, D., Critique textuelle de l'Ancient Testament III, Tome 3, Ezéchiel, Daniel e les 12 Prophètes. Göttingen: Editions Universitaires Fribourg Suisse, Vandenhoeck \& Ruprecht, 1992.

BODA, M. J., The Book of Zechariah, The New International Commentary on the Old Testament. Cambridge: Eerdmans Publishing, 2016. 
BRIGHT, J., A History of Israel. Lousville, Kentucky: Westminster John Knox Press, 1946.

CRAIGIE, P. C., Micah, Nahum, Habakkuk, Zephaniah, Haggai, Zechariah and Malachi, Twelve Prophets, v. 2. Louisville/ London: Westminster John Knox Press, 1985.

CRÜSEMANN, F., A Torá, teologia e história social da lei do Antigo Testamento Petrópolis: Editora Vozes, 1992.

CUNDALL, A. E., MORRIS, L., Juízes e Rute introdução e comentário, Vida Nova, 1986.

De VAUX, R., Instituições de Israel no Antigo Testamento. São Paulo: Vida Nova, 2004.

DIAS, E. C., A vida de Sara e o cumprimento da promessa-aliança: exegese narrativa de Gn 23,1-20. Rio de Janeiro, Tese Doutorado - Departamento de Teologia, Pontifícia Universidade Católica do Rio de Janeiro, 2016.

DOUGLAS, M., As lágrimas de Jacó, o trabalho sacerdotal de reconciliação. São Paulo: Loyola, 2004.

EICHRODT, W., Teologia do Antigo Testamento. São Paulo: Hagnos, 2004.

FERNANDES, L. A., Rute. São Paulo: Paulinas, 2012.

FERNANDES, L. A., Evangelização e família: subsídio bíblico, teológico e pastoral. São Paulo: Paulinas, 2015.

FREVEL, C., Aschera und der Ausschließlichkeitsanspruch YHWHs. Beiträge $\mathrm{zu}$ literarischen, religionsgeschichtlichen und ikonographischen Aspekten der Ascheradiskussion. Jerusalém: SLM Press; Tübigen: TOBIASlib, 1995.

FINITSIS, A., Visions and Eschatology. A Socio-Historical Analysis of Zecharia 1-6. London/New York, Bloomsbury T\&T Clark, 2011.

FOHRER, G., História da Religião de Israel. São Paulo: Paulus/Academia Cristã, 2012.

GAILEY, J. H. Jr. (Ed.), Biblia Hebraica Quinta. The Layman's Bible Commentary, Micah, Nahum, Habakkuk, Zephaniah, Haggai, Zechariah, Malachi, v. 15. Richmond/ Virgínia: John Knox Press, 1962.

GELSTON, A. (ed.), Biblia Hebraica Quinta. The Twelve Minor Prophets. Stuttgart, Deutsche Bibelgesellschaft, 2010. 
GERSTENBERGER, E. S., Israel no tempo dos persas - séculos V e IV antes de Cristo. São Paulo: Loyola, 2005.

GESENIUS, W., Gesenius'Hebrew Grammar. New York: E. Kautzsch, Dover Publications, Inc, 2006.

GIDDENS, A., Sociologia. Lisboa: Fundação Calouste Gulbenkian, 2001.

GIRARD, R., O bode expiatório. São Paulo: Paulus, 2004.

GIRARD, R., A rota antiga dos homens perversos. São Paulo: Paulus, 2009.

GUNNEWEG, A. H. J., História de Israel dos primórdios até Bar Kochba e de Theodor Herzl até nosso dias. São Paulo: Loyola/ Teológica, 1989.

HALLASCHKA, M., Hagggai und Sacharja 1-8: eine redaktionsgeschichtliche Untersuchung. Berlin/New York: Walter de Gryter GmbH \& Co. KG, 2010.

HANHART, R., Septuaginta, Sociedade Bíblica do Brasil, Deutsche Stuttgart: Bibelgesellschaft, 2006.

HILL, A. E., "Haggai, Zechariah and Malachi an Introduction and Commentary". In: Tyndale Old Testament Commentaries, v. 28, London: Inter-Varsity Press / Academic, 2012.

JEREMIAS, C., Die Nachtgesichte des Sacharja. Göttingen: Vandenhoeck \& Ruprecht, 1977.

JOSEPHUS, F. The New Complete Works of Josephus. Grand Rapids: Kregel, 1999.

JOÜON, P., MURAOKA, T., A Grammar of Biblical Hebrew. Roma, 2013.

KESSLER, R., História social do antigo Israel. São Paulo: Paulinas, 2009.

KIDNER, D., Esdras e Neemias, Introdução e comentário. São Paulo: Vida Nova, 1979.

KIPPENBERG, H. G., Religião e formação de classes na Antiga Judéia. São Paulo: Paulinas, 1988.

LAMARCHE P., Zacharie IX-XIV. Structure littéraire et messianisme. Paris: Gabalda et Cie, 1961.

LEVINSON, B. M., Revisão legal e renovação religiosa no antigo Israel. São Paulo: Paulus, 2008.

LIVERANI, M., Para além da Bíblia, história antiga de Israel. São Paulo: Paulus/Edições Loyola, 2003.

LIMA, M. L. C., Mensageiros de Deus: profetas e profecias no Antigo Israel, Rio de Janeiro: Editora PUC Rio, Editora Reflexão, 2012. 
LIMA, M. L. C., Exegese bíblica teoria e prática. São Paulo: Paulinas, 2014.

LOWTH, R., Lectures on the Sacred Poetry of the Hebrews. London: TEGG \& Co. Dublin; Griffin \& Co. Glasgow; Sydney: James and Samuel Augustus TEGG, 1839.

MACDONALD, W., Comentário bíblico popular Antigo Testamento. São Paulo: Mundo Cristão, 1989.

MASON, R., The book of Haggai: Zechariah and Malachi. Cambridge / London / New York / New Rochelle / Melbourne / Sydney: Cambridge University Press, 1977.

MEYERS, C. L.; MEYERS, E. M., Haggai, Zechariah 1-8. New Haven $\varepsilon$ London: The Anchor Yale Bible, 1987.

MILLS, M. E., Urban Imagination in Biblical Prophecy. New York/London/New Delhi/Sydney: Bloomsbury, 2012.

OLLENBURGER, Ben C., The Book of Zechariah, Introduction, Commentary and Reflections. Nashiville: Abingdon Press Publisher, 1996.

OLMSTEAD, A. T., History of the Persian Empire. London: The University of Chicago Press, 1948.

PARKER, R.; DUBBERSTEIN, W. H., Babylonian Chronology 626 B.C.-A.D. 45, Studies in Ancient Oriental Civilization, n. 24. Chicago/Illinois: The University of Chicago Press, 1942.

PETERSEN, D. L., Haggai and Zechariah 1-8: A Commentary. Philadelphia/Pennsylvania: The Westminster Press, 1984.

PROVAN, I., LONG, V.P., LONGMAN III, T., Uma história bíblica de Israel. São Paulo: Vida Nova, 2016.

RIGNELL, L.G., Die Nachtgesiche des Sacharja: Eine exegetische Studie, Lund: Gleerup, 1950.

RUDOLPH, W., Haggai - Sacharja 1-8 - Sacharja 9-14 - Maleachi, Mit einer Zeittafel von Alfred Jepsen, Gütersloh, Gütersloher Verlagshaus Gerd Mohn, 1976.

SCHART, A., KRISPENZ, J. (orgs.), Die Stadt im Zwölf-Propheten-Buch. Berlin/Boston: De Gruyter, 2012.

SCHÜNGEL-STRAUMMANN, H., Die Frau Am Anfang Eva und die Folgen, Exegese in unserer Zeit. Münster/Hamburg/London, 1989. 
SICRE DIAZ, J. L., Introdução ao profetismo bíblico. Petrópolis: Editora Vozes, 2012.

SKA, J.-L., O canteiro do Pentateuco, problemas de composição e de interpretação, aspectos literários e teológicos. São Paulo: Paulinas, 2016.

SMITH, R. L., "Michah-Malachi”, Word Biblical Commentary, v. 32. Texas: Word Books Publisher 1984.

SMITH, R. L., Teologia do Antigo Testamento, história, método e mensagem, São Paulo: Vida Nova, 2001.

STEAD, M. R., The Intertextuality of Zechariah 1-8. London/ New York: T\&T Clark, 2009.

SWEEnEY, M. A. The Twelve Prophets, v. 2. col. Berit Olam, Collegeville: The Liturgical Press, 2000.

TENNEY, M. C., PACKER, J. I., WHITE Jr., W., Vida cotidiana nos tempos bíblicos. São Paulo: Editora Vida, 1982.

VIEGAS, A. S., Uma heroína chamada Rute: análise narrativa e intertextual de Rt 3. Rio de Janeiro, Tese Doutorado - Departamento de Teologia, Pontifícia Universidade Católica do Rio de Janeiro, 2017.

\section{Artigos e capítulos}

ACKROYD, P. R., “The book of Haggai and Zechariah I-VIII”. In: JJS 3 (1952).

ALMEIDA, F. P. M., “Zacarias o livro pela pesquisa”. In: REET 3 (2008), $<$ https://revistas.pucsp.br/reveleteo/article/view/6763/4893>. Acesso: 13 abr. 2019.

ASSIS, E., “Zechariah's Vision of the Ephah (Zech. 5:5-11)”. In: VT 60 (2010), pág. 15-32.

ASSIS, E., "The Structure of Zechariah 8 and its Meaning". In: JHS 12/12 (2012), p. 1-18.

BERGANT, D., KARRIS, R. J. (orgs.), Comentário Bíblico. São Paulo: Loyola, 1989.

- BOADT, L. E., "Provérbios”, v. 2, p. 235-259.

- BOWES, P. J., “1 e 2 Samuel”, v. 1, p. 247-271.

- BURNS, R. J., "Esdras e Neemias”, v. 2, p. 303-332. 
- CRAVEN, T., "Ezequiel”, v. 2, p. 67-87.

- CRAGHAN, J. F., "Êxodo”, v. 1, p. 91-120.

- CLIFFORD, R. J., “Salmos”, v. 2, p. 207.

- COLLINS, J. J., “Isaías”, v. 2, p. 11-44.

- FISCHER, J. A., "Rute”, v. 2, p. 261-266.

- GRINDEL, J. A., “Juízes”, v. 1, p. 233-246.

- HOPPE, L. J., “Deuteronômio”, v. 1, p. 187-213.

- LAFFEY, A. L., 1 e 2 Crônicas, v. 2, p. 333-341.

- MAINELLI, H. K., “Números”, v. 1, p. 145-185.

- PAZDAN, M. M., “Malaquias”, v. 2, p. 176-181.

- PAZDAN, M. M., “Zacarias”, v. 2, p. 155-167.

- TURNER, W. A., "Levítico”, v. 1, p. 121-143.

- VIVIANO, P. A., “Gênesis”, v. 1, p. 55-89.

BODA, M. J., FLOYD, M. (orgs.), Tradition in Transition Haggai and Zechariah 1-8 in the Trajectory of Hebrew Theology. New York/London: T\&T Clark, 2008.

- DELKURT, H., "Sin and Atonement in Zechariah's Night Visions", p. 235-251.

- FLOYD, M. H., "Traces of Tradition in Zechariah 1-8: A Case-Study”, p. 235-251.

- MASON, R., "Footprints to the Post-Exilic Prophets", p. 310-318.

- PETERSEN, D. L., “Haggai-Zechariah 1-8: Some Reflections”, p. 319326.

- REDITT, P. L., "The King in Haggai-Zechariah 1-8 and the Book of the Twelve", p. 56-82.

- SCHNOCKS, J., "An Ephah Between Earth and Heaven: Reading Zechariah 5:5-11”, p. 252-270.

BODA, M. J., "From Fast to Feasts: The Literary Function of Zechariah 7-8”. In: CBQ 65 (2003), p. 390-407.

BUNCE, H., "Translation and Interpretation: Targum and Septuagint in Zechariah 5:5-11”. In: CBW 31 (2011), p. 53-65.

CARSON, D. A.; FRANCE, R. T.; MOTYER, J. A.; WENHAM, G. J. (orgs.), Comentário bíblico Vida Nova. São Paulo: Vida Nova, 1994.

- BALDWIN, J., "Rute”, p. 438-450. 
- BUTTERWORTH, M., “Zacarias”, p. 1308-1309.

- HUNGENBERGER, G. P., “Malaquias”, p. 1224-1335.

- McGREGOR, L.J., “Ezequiel”, p. 1096-1097.

- STURT, D., “Jonas”, p. 1225-1236.

- WENHAM, G. J., "Gênesis”, p. 92-149.

- WEBB, B. G., “Juízes”, p. 399-437.

- WILLIAMSON, H. G. M., “Esdras e Neemias”, p. 640-671.

DELCOR, M., "La vision de la femme dans l'épha de Zach. 5, 5-11 à la lumière de la littérature hittite". In: RHR 187, 2 (1975), 137-145.

EMMERSON, G., “Zechariah”. In: EMMERSON, G., Prophets II: Nahum, Habakkuk, Zephaniah, Haggai, Zechariah, Malachi. New York / London / Toronto / Sydney / Auckland: Doubleday, 1998, p. 104-105.

ESKENAZI, T. C., "Out From the Shadows: Biblical Women in the Postexilic Era”. In: JSOT 54 (1992), p. 23-46.

FERNANDES, L. A., "A família conduzida pela palavra de Deus: Salmo 127". In: FERNANDES, L. A., M. GRENZER, Dança, ó Terra! Interpretando Salmos. São Paulo: Paulinas, 2013, p. 215-245.

FERNANDES, L. A., "Séfora: a mulher proativa que livra o homem da morte (Ex 4,24-26)". In: RCT, XXII/86 (2015), p.59-84.

FERNANDES, L. A., “Aborto justificado? O equívoco da leitura e da interpretação espúria de Ex 21,22-25; Nm 5,11-31; Sl 139,16”. In: Vox Scripturae XXVI/3 (2018), p. 439-461.

FLOYD, M. H. Floyd, "The Evil in the Ephah: Reading Zechariah 5: 5-11 in Its Literary Context”. In: CBQ 58 (1996), p. 51-68.

GALLING, K., "Die Exilswende in der Sicht des Propheten Sacharja". In: VT 2, 1 (1952), p. 18-30.

HANHART, R., “Dodekapropheton 7.1: Sacharja 1-8”. In: BKAT 14/7 (1998), Neukirchen-Vluyn, p. 19.

HAYES, E. R., TIEMEYER, L-S. (orgs.), I Lifted My Eyes And Saw, Reading Dream and Vision Reports in The Hebrew Bible. London/Oxford/New York/New Delhi/Sydney: Bloomsbury, 2014.

- BODA, M. J., "Writing the Vision: Zechariah Within the Visionary Tradition of the Hebrew Bible", p. 101-118. 
- HALLASCHKA, M., “Interpreting Zechariah's Visions: RedactionCritical Considerations on the Night Vision Cycle (Zechariah 1,7-6,8”, p. 135-148.

- PETTERSON, A. R., “The Eschatology of Zechariah's Night Visions”, p. 119-134.

- STEAD, M. R., “The Interrelationship Between Vision and Oracle in Zechariah 1-6”, p. 149-168.

- WERLINE, R. A., "Assessing the Prophetic Vision and Dream Texts for Insights into Religious Experience", p. 1-15.

JANOWSKI, B.,"Der Mensch im alten Israel - Grundfragen alttestamenthcher Anthropologie". In: ZThK 102 (2005), p. 143-175.

KLINE, M. G., "The Structure of the Book of Zechariah". In: JETS, 34/2 (1991), p. 179-193.

KNOPPERS G. N., "Parallel Torahs and Inner-Scriptural Interpretation: The Jewish and Samaritan Pentateuchs in Historical Perspective". In: DOZEMAN, T. B./SCHMID, K./SCHWARTZ, B. J., The Pentateuch International Perspectives on Current Research. TübingenT: Mohr Siebeck, 2011, p. 507-532),

KNOPPERS, G. N., GRABBE, L. L.; FULTON, D. (orgs.), Exile and Restorarion Revisited. New York: T\&T Clark, 2009.

- GRABBE, L. L., “'The Shall Come Rejoicing to Zion' - Or Did They? The Settlement of Yehud in the Early Persian Period", p. 116-127.

- KRATZ, R. G., "The Relation between History and Thought: Reflections on the Subtitle of Peter Ackroyd's Exile and Restoration", p. 152-165.

- MEYERS, E. M., "Exile and Restoration in Light of Recent Archaelogy and Demographic Studies”, p. 166-173.

- RISTAU, K. A., “Rebuilding Jerusalem: Zechariah's Vision Within Visions", p. 195-213.

KÖRTING, C., "Sach 5,5-11 - Die Unrechtmäßigkeit wird an ihren Ort verwiesen”. In: Bib 87/4 (2006), p. 478-491.

LIMA, M. L. C., “Doze Profetas ou Livro dos Doze?”. In: ATeo 11 (2001), p. 194-216.

LONG, B. O., "Reports of Visions among the Prophets". In: JBL, 95/3 (1976), p. 363-364. 
MARENOF, S., "Note Concerning The Meaning of the Word 'Ephah', Zechariah, 5:5-11”. In: AJSL 48 (1932), p. 264-267.

MAY, H. G., “A Key to the Interpretation of Zechariah's Visions”. In: JBL 57/2 (1938), <http://www.jstor.org/stable/3259747> Acessado: 18 10-2016 11:25.

McCOMISKEY, T. E., “Zechariah”. In: McCOMISKEY, T. E. (Ed.), The Minor Prophets, v. 3. Michigan: Grand Rapids, 1992, p. 1099-1101.

OPORTO, S. G., GARCÍA, M. S. (eds.), Comentário ao Antigo Testamento. São Paulo: Ave-Maria, 1997.

- MELERO, E. C., "Rute”, v. I, p. 619-628.

- RIVAS, P. J., “Jonas”, v. II, p. 339-342.

- RIVAS, P. J., “Zacarias”, V. II, p. 375-387.

PAKALA, J. C., "Short Contribution, A Librarian's Comments on Commentaries: 31”, Presbterion, 37/1 (2011), p. 49-53

PELLEGRINI, T., "Narrativa verbal e narrativa visual: possíveis aproximações". In: Literatura, Cinema e Televisão. São Paulo: SENAC, 2003.

ROTHSTEIN J. W., "Die Nachtgesichte des Sacharja Studien zur Sacharjaprophette und zur judischen Geschichte im ersten nachexiloischen". In: BWAT 8 (1910), p. 146-154.

RUDMAN, D., “Zechariah 5 and The Priestly Law”. SJOT 14 (2000), p. 194 206.

SIQUEIRA, F. S., "Ml 1,6-14: A crítica profética ao culto do Segundo Templo e sua justificativa sob o aspecto teológico”. Atualidade Teológica, 46 (2014), p. 195-212.

SEUFERT, M., “Zechariah 5:5-11: Why an ephah?”. VT 65 (2015), p. 289-296.

UELINHGER, C., “Die Frau im Efa (Sach 5,5-11) Eine Programmvision von der Abschiebung der Göttin”. In: BK 49 (1994), p. 93-102.

TIEMEYER, L-S., "The Vision Report Genre between Form-Criticism and Redaction-Criticism: An Investigation of Amos 7-9 and Zechariah 1-6". In: BODA, M. J., FLOYD, M., TOFFELMI, C. M. (orgs.), The Book of Twelve and the New Form Criticism. Society of Biblical Literature/Ancient Near East Monographs. Atlanta: SBL Press, 2015, p. $75-96$. 